\title{
NuEVAS APORTACIONES A LA CARACTERIZACIÓN MOLECULAR DEL GEN CHN2
}

Laura Barrio Real 2011 



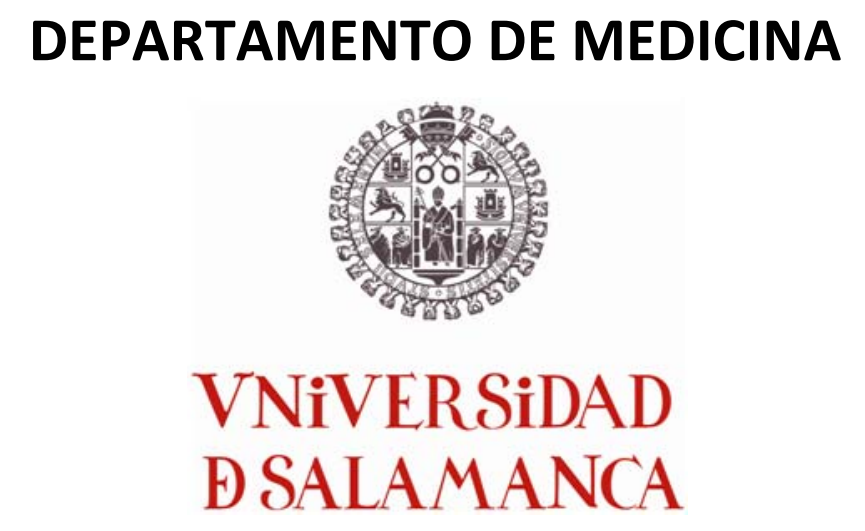

TESIS DOCTORAL:

NUEVAS APORTACIONES A LA

CARACTERIZACIÓN MOLECULAR DEL GEN CHN2.

LAURA BARRIO REAL

2011 



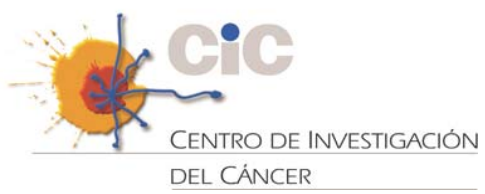

el Dr. Rogelio gONZÁlez SARMiento, CATEDRÁtico de medicina del DEPARTAMENTO DE MEDICINA DE LA UNIVERSIDAD DE SALAMANCA

\section{CERTIFICA:}

Que el trabajo titulado "Nuevas aportaciones a la caracterización molecular del gen CHN2", que presenta la Licenciada en Biología Laura Barrio Real, ha sido realizado bajo mi dirección, en la Unidad de Medicina Molecular del Departamento de Medicina de la Universidad de Salamanca, y reúne, a mi juicio, originalidad y contenidos suficientes para que sea presentado ante el tribunal correspondiente y pueda optar al título de "Doctora" por la Universidad de Salamanca.

Y para que así conste, y a los efectos oportunos, expido el presente certificado en Salamanca, a 25 de Enero de 2011.

Prof. Dr. Rogelio González Sarmiento 

LA Dra. MARIA JOSÉ CALOCA ROLDÁN, CIENTÍFICA TITULAR DEL CSIC EN EL INSTITUTO DE BIOLOGÍA Y GENÉTICA MOLECULAR (IBGM) DE VALLADOLID

\section{CERTIFICA:}

Que el trabajo titulado "Nuevas aportaciones a la caracterización molecular del gen CHN2", que presenta la Licenciada en Biología Laura Barrio Real, ha sido realizado bajo mi dirección, en la Unidad de Medicina Molecular del Departamento de Medicina de la Universidad de Salamanca, y reúne, a mi juicio, originalidad y contenidos suficientes para que sea presentado ante el tribunal correspondiente y pueda optar al título de "Doctora" por la Universidad de Salamanca.

Y para que así conste, y a los efectos oportunos, expido el presente certificado en Salamanca, a 25 de Enero de 2011.

Dra. Maria José Caloca Roldán 

Esta tesis es de mucha gente, personas que me han ayudado de alguna u otra manera. Todos están en mi corazón, y espero que a ninguno de vosotros se me olvide agradeceros vuestra ayuda en estas líneas.

Para empezar, quiero agradecer a Rogelio y a Maria José la dirección de esta tesis. He aprendido mucho de vosotros. Ambos habeís confiado en mí y espero no haberos decepcionado.

A mis compañeros del labo, por aguantar mis tonterías a todas horas (que son muchas y muy variadas)... Gracias por regalarme vuestra sabiduría, los cafés, las cañas y los pinchos, las fiestas, los viajes, las fotos censuradas... Porque el ambiente que generamos entre todo, que hace que vayas a trabajar con una sonrisa. Porque además de mis compañeros, sois mis amigos.

Al laboratorio 7 del $\mathrm{CIC}$, porque siempre soy bien recibida allí.

A Isabel Pastor, por su apoyo. A Miguel por sus cursos de estadística para torpes.

A los Becquer's porque estáis ahí, por aguantarme con mi monotema desde hace un año, la tesis, porque me reconfortáis siempre que lo necesito, porque habeis hecho que haya sobrevivido a estos meses.

A Pilar, que siempre está ahí. Porque es mi ejemplo de lucha.

Y para acabar un enorme GRACIAS a los más cercanos, a mi familia, a toda ella, pero en especial a mis padres y a mi hermano, que me riñen porque no me salen los experimentos, que me consuelan cuando me frustro y que se alegran aún más que yo cuando las cosas me salen bien.

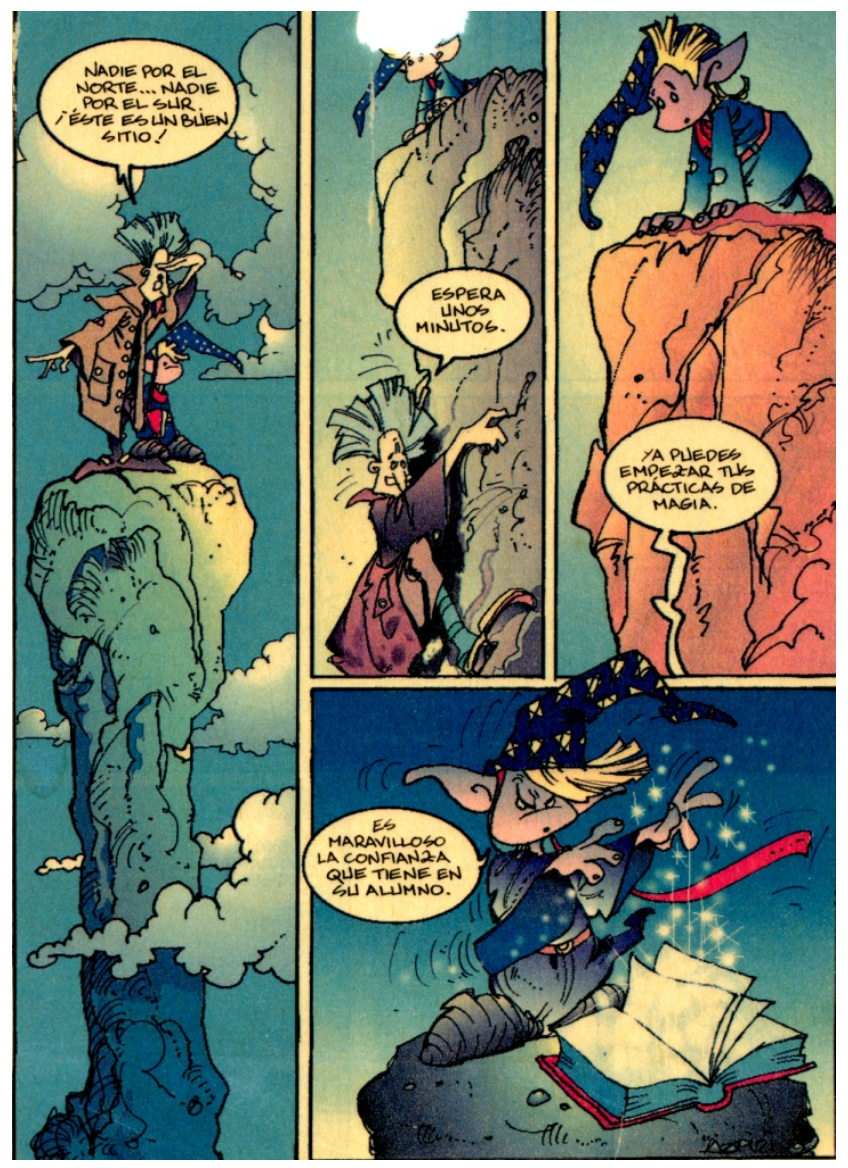



INDICE 

INDICE.

I. CONCEPTOS GENERALES.

II. LA GTPASA RAC.

II.1. Funciones de Rac1. 28

II.1.a. Regulación de la polimerización el citosqueleto de actina. 29

II.1.b. Regulación de la transcripción. 29

II.1.c. Otras funciones. $\quad 30$

II.2. Enfermedades causadas por alteraciones en la ruta de Rac. ............................ 30

II.2.a. Infecciones bacterianas.

II.2.b. La GTPasa Rac y el cáncer.

III. LAS QUIMERINAS. 34

III.1. Genes de las quimerinas. ................................................................... 34

III.2. Estructura y propiedades bioquímicas de las quimerinas.............................. 37

III.2.a. El dominio SH2 37

III.2.b. El dominio C1 de quimerinas: las quimerinas como nuevos receptores de DAG. 39

III.2.c. El dominio GAP: las quimerinas como reguladores de la GTPasa Rac 41

III.2.d. Estructura tridimensional de la 82-quimerina y modelo de activación $\quad 42$

III.3. rutas de señalización reguladas por las quimerinas ....................................... 44

III.3.a. Las quimerinas como efectores de receptores tirosina quinasa y GPCRs.

III.3.b. Interacción con otras proteínas $\quad 45$

III.4. Funciones biológicas de las quimerinas. .................................................... 46

III.4.a. Quimerinas y el sistema nervioso $\quad 46$

III.4.b. Quimerinas y el sistema inmune. $\quad 48$

$\begin{array}{ll}\text { III.4.c. Quimerinas y desarrollo. } & 48\end{array}$

III.5. enfermedades asociadas con alteraciones de las quimerinas. .......................... 48

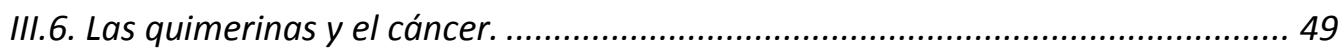


HIPÓTISIS Y OBJETIVOS 53

I. HIPÓTESIS

II. OBJETIVOS.

MATERIAL Y MÉTODOS …........................................................ 57

I. PLÁSMIDOS. 59

II. LÍNEAS CELULARES Y CONDICIONES DE CULTIVO. 60

III. MANIPULACIÓN DE LOS ÁCIDOS NUCLEICOS. 61

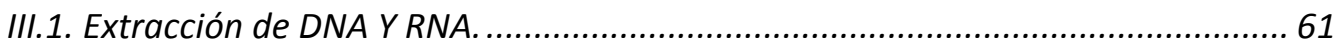

III.1.a. Extracción de DNA. 61

III.1.b. Extracción del RNA. 62

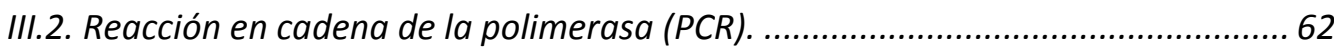

III.2.a. PCR de Transcripción inversa (RT-PCR). 63

IV. ANÁLISIS MUTACIONAL DEL GEN CHN2. 63

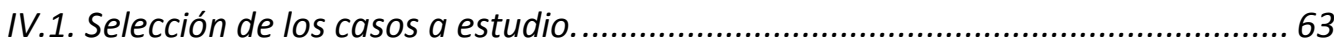

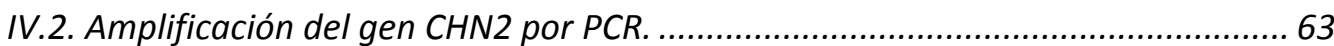

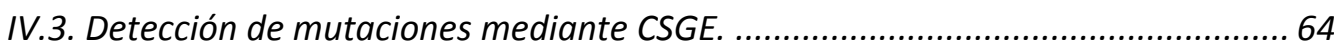

V. ESTUDIOS POBLACIONALES DE POLIMORFISMOS DEL GEN CHN2. 65

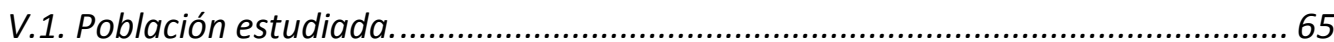

V.1.a. Estudios poblacionales en cáncer.

V.1.b. Estudios poblacionales en drogodependencias (tabaquismo y alcoholismo). 66

V.2. Genotipado de los polimorfismos del gen CHN2 ........................................... 68

V.2.a. Análisis de los polimorfismos por longitud de los fragmentos de restricción

(RFLP).

V.2.b. Discriminación alélica por sondas TaqMan. 69

V.2.c. Discriminación alélica mediante cromatografía líquida de alto rendimiento desnaturalizante (dHPLC). 69

V.2.d. Análisis estadístico en los estudios de asociación.

VI. TRANSFECCIONES TRANSITORIAS Y ESTIMULACIÓN CELULAR. 71 
VII. MICROSCOPÍA CONFOCAL E INMUNOFLUORESCENCIA INDIRECTA. 71

VIII. ELECTROFORESIS DE PROTEÍNAS Y WESTERN BLOT. 72

IX. PURIFICACIÓN DEL DOMINIO RBD. 73

X. DETERMINACIÓN DE LA ACTIVIDAD DE RAC: ENSAYO DE PULL-DOWN. 74

$\begin{array}{ll}\text { XI. PCR CUANTITATIVA. } & 74\end{array}$

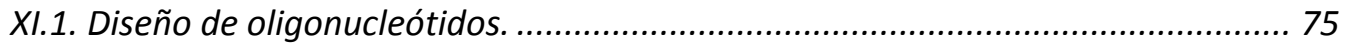

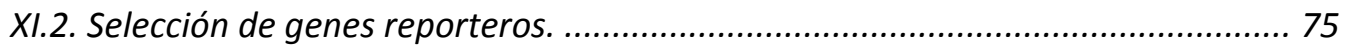

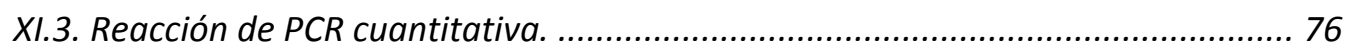

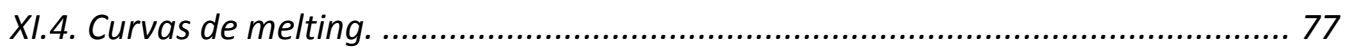

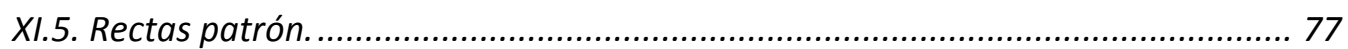

XII. ESTUDIOS DE METILACIÓN DEL PROMOTOR. 78

XII.1. Estudios bioinformáticos predictivos del promotor......................................... 78

XII.2. Modificación del DNA por bisulfito................................................................ 78

XII.3. Amplificación del promotor y secuenciación. .................................................... 79

XII.4. Desmetilación del promotor por tratamiento con 5-Aza-2'-deoxicitidina

(AZA). 80

RESULTADOS 81

I. ANÁLISIS MUTACIONAL DEL GEN CHN2.

1.1. Búsqueda de mutaciones patogénicas del gen CHN2 asociadas con cáncer......... 83

I.2. Análisis de los polimorfismos del gen CHN2 .................................................... 86

1.2.a. Análisis de polimorfismos del gen CHN2 en pacientes con cáncer. 86

I.2.a.1 Estudio de asociación de los polimorfismos del gen CHN2 con síndrome

mielodisplásico

I.2.a.2 Estudio de asociación de los polimorfismos del gen CHN2 con los tumores del

Sistema Nervioso Central

I.2.a.3 Estudio de asociación de los polimorfismos del gen CHN2 con el cáncer de mama........92

l.2.b. Análisis de los polimorfismos del gen CHN2 en drogodependencias. 93

I.2.b.1 Asociación de los polimorfismos del gen $\mathrm{CHN2}$ y el tabaquismo.....................................94

I.2.b.2 Asociación de los polimorfismos del gen CHN2 y el alcoholismo.....................................97 
II. ANÁLISIS TRANSCRIPCIONAL Y FUNCIONAL DEL GEN CHN2.

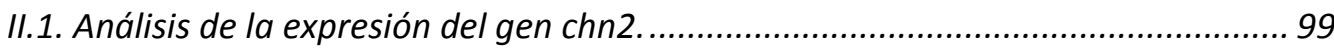

II.2. Variantes transcripcionales del gen CHN2.................................................... 101

II.2.a. Descripción de nuevas variantes del gen CHN2. 101

II.2.a.1 Variantes derivadas del preRNA mensajero de $\beta 2$-quimerina. ..................................... 101

II.2.a.2 Variantes derivadas del preRNA mensajero de $\beta 1$-quimerina. ...................................... 103

II.2.b. Caracterización funcional de nuevas variantes del gen CHN2. 105

II.2.b.1 Análisis de la localización subcelular de las variantes del gen CHN2 . ............................ 107

II.2.b.2 Análisis de la actividad GAP de las variantes del gen CHN2 ....................................... 110

II.2.c. Estudio de expresión diferencial de los tránscritos del gen CHN2. 114

II.2.c.1 Expresión diferencial de los tránscritos del gen CHN2 en líneas celulares de cáncer

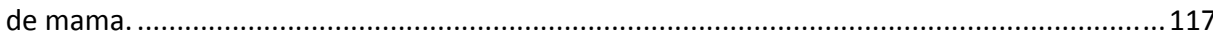

II.2.d. Expresión diferencial de los tránscritos del gen CHN2 en líneas celulares de tumores del sistema nervioso central. 118

II.3. Estudio de la regulación de la transcripción del gen CHN2............................... 120

II.3.a. Análisis bioinformático de los promotores de 61-y 82-quimerina. 120

II.3.a.1 Análisis de la metilación del primer promotor del gen CHN2 ................................... 121

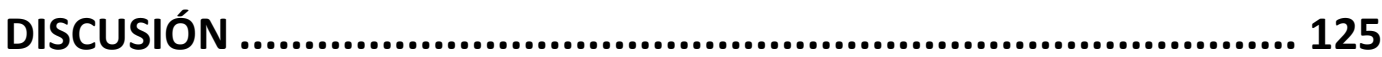

\begin{tabular}{ll} 
I. & EL GEN CHN2 Y EL CÁNCER. \\
\hline
\end{tabular}

II. OTRAS ENFERMEDADES ASOCIADAS AL GEN CHN2. 133

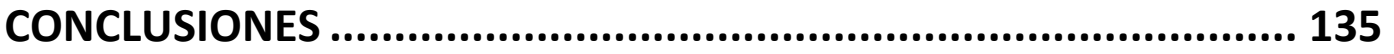

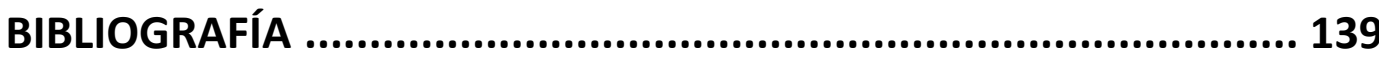


TABLA DE

ABREVIATURAS 



\begin{tabular}{|c|c|c|}
\hline aa & Aminoácido & \\
\hline AC & Astrocitoma & \\
\hline APA & Asociación Americana de Psiquiatría & American $\underline{P}$ sychiatric $\underline{\text { Association }}$ \\
\hline aPCK & PCK atípica & \\
\hline ATCC & Colección americana de tipos celulares en cultivo & American Type Culture Collection \\
\hline AZA & 5-AZA-2'-deoxicitidina & \\
\hline BSP & Secuenciación por PCR dependiente de bisulfito & $\underline{B}$ isulfite sequencing- $\underline{P} C R$ \\
\hline C1 & Dominio C1 de interacción con ésteres de forbol & \\
\hline Cdk5 & Quinasa dependiente de ciclina 5 & Cyclin-dependent kinase $\underline{5}$ \\
\hline cDNA & DNA complementario & \\
\hline CHN1 & Gen $\alpha$-quimerina & \\
\hline CHN2 & Gen $\beta$-quimerina & \\
\hline CpG & Dinucleótidos de 5' Citosina-Guanina 3' & \\
\hline cPKC & PKC clásica & \\
\hline CpNpG & 'Trinucleótidos de 5' Citosina-Nucleótido-Guanina 3' & \\
\hline CRMP-2 & Proteína mediadora de la respuesta a colapsina 2 & Collapsin-response mediator protein- $\underline{\underline{2}}$ \\
\hline CSGE & Electroforesis en gen sensible a conformación & $\begin{array}{l}\text { Conformation Sensitive Gel } \\
\text { Electrophoresis }\end{array}$ \\
\hline C-terminal & Extremo carboxilo & \\
\hline DAG & Diacilglicerol & \\
\hline DAPI & Diclorhidrato de 4',6-diamidino-2-fenilindol & 4',6-diamidino-2-phenylindole \\
\hline DGK & Diacilglicerol quinasa & Diacylqlycerol kinase \\
\hline dHPLC & $\begin{array}{l}\text { Cromatografía líquida de alta presión } \\
\text { desnaturalizante }\end{array}$ & $\begin{array}{l}\text { denaturing } \underline{H} \text { igh } \underline{\text { Pressure Liquid }} \\
\text { Cromatography }\end{array}$ \\
\hline DLC-1 & Gen Delecionado en el Hígado 1 & Deleted in Liver $\underline{\text { Cancer }} \underline{1}$ \\
\hline DSMZ & $\begin{array}{l}\text { Colección alemana de microorganismos y cultivos } \\
\text { celulares }\end{array}$ & $\begin{array}{l}\text { Deutsche Sammlung von } \\
\underline{\text { Mikroorganismen und Zellkulturen }}\end{array}$ \\
\hline DSM-IV & $\begin{array}{l}\text { Manual de diagnóstico y estadística de trastornos } \\
\text { mentales-IV }\end{array}$ & $\begin{array}{l}\text { Diagnostic and Statistical Manual of } \\
\text { Mental Disorders }-\underline{I V}\end{array}$ \\
\hline EGF & Factor de crecimiento epitelial & Epitelial growth factor \\
\hline EGFP & GFP potenciada & Enhanced GFP \\
\hline EGFR & Receptor de EGF & EGF receptor \\
\hline EphA2 & Receptor de Efrina A2 & \\
\hline EphA4 & Receptor de Efrina A4 & \\
\hline ERK & Quinasa regulada por señales extracelulares & Extracellular signal-regulated kinases \\
\hline ESE & $\begin{array}{l}\text { Sitio de unión de un potenciador del splicing } \\
\text { exónico }\end{array}$ & Exonic splicing enhancer \\
\hline ESS & Sitio de unión de un inhibidor del splicing exónico & Exonic splicing silencer \\
\hline
\end{tabular}


FBS

FL

GAP

GAPDH

GB

GDI

GDP

GEF

GFP

GPCR

GRAF

GST

GTP

GWAS

HRG

HRP

HWE

INS

JNK

LCC

LPA

mAChR1

MG

mRNA

NA

NADPH

NES

NFAT

NFKB

NGF

NLS

nPCK

NR2A
Suero Bovino fetal

Isoforma completa

Proteína Activadora de la GTPasa

Gliceraldehido 3-fosfato deshidrogenasa

Glioblastoma

Inhibidor de la disociación del GDP

Guanosín difosfato

Factor de intercambio de nucleótidos de guanina

Proteína verde fluorescente

Receptor acoplado a la proteína G

Regulador de GTPasa asociado con la quinasa de adhesión focal $\mathrm{p} 125^{\mathrm{FAK}}$

Glutation-S- $\underline{\text { transferasa }}$

Guanosín trifosfato

Estudio de asociación del genoma completo

Heregulina

Peroxidasa de rábano

Equilibrio de Hardy-Weinberg

Gen del precursor de la insulina

Quinasa N-terminal de Jun

Citotoxina de Clostridium

Ácido lisofosfatídico

Receptor de acetilcolina muscarínico 1

Meningioma

RNA mensajero

No analizado

Nicotinamida adenina dinucleótido fosfato

Señal de exportación nuclear

Factor nuclear de células T activadas

Factor nuclear кB

Factor de crecimiento neuronal

Señal de localización nuclear

PCK novel

Subunidad 2A del receptor NMDA
Foetal bovine serum

Full lenght

GTPase-activating Protein

Glyceraldehyde 3-phosphate dehydrogenase

GDP-dissociation Inhibitors

Guanosine diphosphate

Guanine nucleotide Exchange Factors

Green Fluorescent Protein

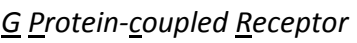

GTPase regulator associated with the focal adhesion kinase $p 125^{\text {FAK }}$

Guanosine triphosphate

Genome-wide association study

Horseradish peroxidase

c-Jun N-terminal kinase

Large clostridium cytotoxins

Lysophosphatidic acid

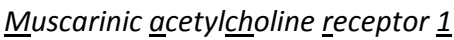

Nicotinamide adenine dinucleotide phosphate

Nuclear export signal

$\underline{N}$ uclear factor of activated $\underline{T}$-cell

Nuclear factor kappa-light-chainenhancer of activated $\underline{B}$ cells

Nerve growth factor

Nuclear localization signal

NMDA [N-methyl-D-aspartate] receptor subunit $2 \mathrm{~A}$ 


\begin{tabular}{|c|c|c|}
\hline $\mathrm{N}$-terminal & Extremo amino & \\
\hline OMS & Organización mundial de la salud & \\
\hline PA & Ácido fosfatídico & Phosphatidic acid \\
\hline PAK & Quinasa activadora de p21 & p21-activated Protein Kinase \\
\hline pb & Pares de bases & \\
\hline PKC & Proteína quinasa C & Protein $\underline{k}$ inase $\underline{C}$ \\
\hline PKD & Proteína quinasa $\mathrm{D}$ & $\underline{\text { Protein }} \underline{\text { kinase }} \underline{D}$ \\
\hline PLC & Fosfolipasa C & Phospholipase $\underline{C}$ \\
\hline PMA & Forbol 12-miristato 13-acetato & Phorbol 12-myristate 13-acetate \\
\hline PreRNA & RNA inmaduro & \\
\hline PS & Fosfatidilserina & Phosphatidylserine \\
\hline Ptdlns & Fosfatidilinositol & \\
\hline Rac & $\begin{array}{l}\text { Proteína sustituta de la toxina botulínica C3 } \\
\text { relacionada con Ras }\end{array}$ & $\underline{\text { Ras-related } \underline{\mathrm{C}} 3 \text { botulium toxin }}$ \\
\hline RasGRP & Proteína liberadora de guanina de Ras & $\underline{\text { Ras quanine releasing-protein }}$ \\
\hline RBD & Dominio de unión a Rac & $\underline{\text { Rac-binding domain }}$ \\
\hline RFLP & $\begin{array}{l}\text { Análisis de polimorfismos por longitud de los } \\
\text { fragmentos de restricción }\end{array}$ & $\begin{array}{l}\text { Restriction Fragment Lenght } \\
\text { Polymorphism }\end{array}$ \\
\hline Rho & Familia de genes homólogos de Ras & Ras homolog gene family \\
\hline ROS & Radicales superóxido & Reactive oxygen species \\
\hline $\mathbf{R Q}$ & Cantidades relativas & Relative quantities \\
\hline RT-PCR & PCR de Transcripción Inversa & $\begin{array}{l}\text { Reverse transcription polymerase chain } \\
\text { reaction }\end{array}$ \\
\hline SDF-1 $\alpha$ & Factor derivado de las células del estroma- $1 \alpha$ & Human stromal cell-derived factor $\underline{1 \alpha}$ \\
\hline SFK & Quinasa de la familia de SrC & Src-family kinase \\
\hline SH2 & Dominio SH2 homólogo de Src & $\underline{\operatorname{Src}} \underline{H o m o l o g y} \underline{2}$ \\
\hline SMD & Síndrome mielodisplásico & \\
\hline SNC & Sistema nervioso central & \\
\hline SNP & Polimorfismo de nucleótido simple & Single nucleotide polymorphism \\
\hline SRF & Factores de transcripción de respuesta a suero & Serum response factor \\
\hline SPLB & Tampón de carga de proteínas solubles & Soluble protein loading buffer \\
\hline TBP & Proteína de unión a la caja TATA & Iata box-Binding Protein \\
\hline TCR & Receptor de células T & $\underline{T}$-cell receptor \\
\hline TEAA & Acetato de trietilamonio & Triẹthylammonium acetate \\
\hline Tmp21 & Proteína transmembrana 21 & $\begin{array}{l}\text { Transmembrane Trafficking protein, } \underline{21} \\
K d a\end{array}$ \\
\hline
\end{tabular}





\section{INTRODUCCIÓN}





\section{CONCEPTOS GENERALES.}

Los genes CHN1 y CHN2 codifican las proteínas de la familia de las quimerinas, proteínas GAP (GTPase-activating Proteins) implicadas en el control del estado de activación de la GTPasa Rac. Por inicio alternativo de la transcripción de estos genes se generan 4 tránscritos (Fig. 1): $\alpha 1$ - y $\alpha 2$-quimerinas a partir del gen CHN1 y $\beta 1$ - y $\beta 2$ quimerinas por transcripción del gen CHN2. Las cuatro isoformas tienen un dominio catalítico GAP y un dominio C1 de unión a DAG (diacilglicerol) y las isoformas $\alpha 2$ - y $\beta 2$ quimerinas tienen, además, un dominio $\mathrm{SH} 2$ en el extremo amino terminal.

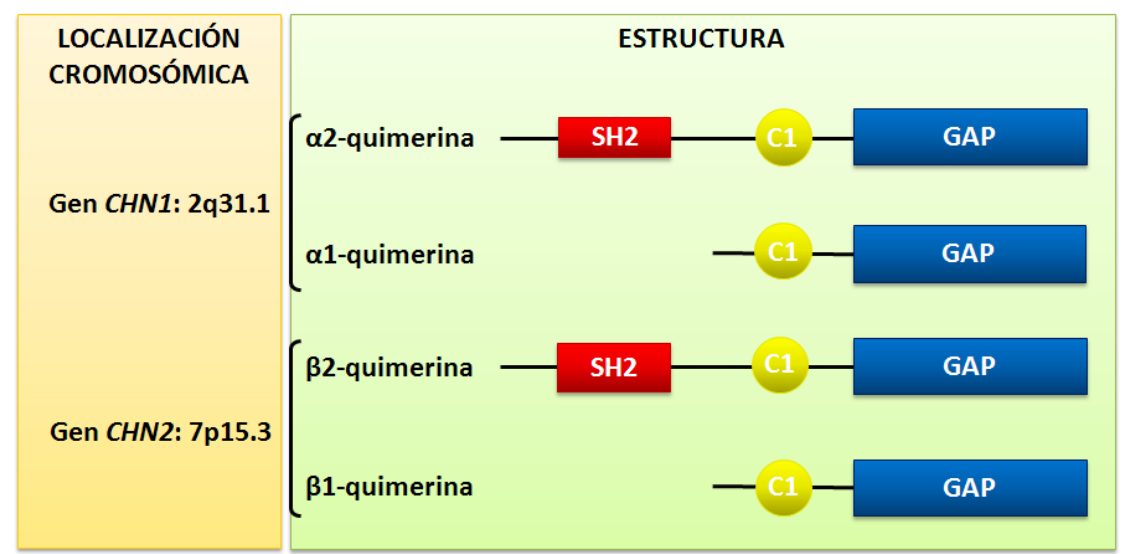

Figura 1: Estructura y localización cromosómica de los cuatro tránscritos generados a partir de inicio alternativo de los CHN1 y CHN2 humanos.

Las funciones biológicas de las quimerinas descritas hasta el momento están vinculadas a su actividad como reguladores negativos de Rac. Rac es uno de los miembros de las Rho GTPasas que, a su vez, constituyen un subgrupo de la superfamilia de proteínas Ras. La familia de las Rho GTPasas se divide en seis subfamilias: la subfamilia Rho, que incluye a RhoA, RhoB y RhoC; la subfamilia Rac, con 4 componentes, Rac1, Rac1b (generada por procesamiento alternativo del gen RAC1), Rac2, Rac3 y RhoG; la subfamilia Cdc42, formada por Cdc42, su variante originada por procesamiento alternativo G25K y las proteínas TC10, TCL, Chp/Wrch-2 y Wrch-1; la subfamilia Rnd, constituida por las proteínas Rnd1, Rnd2 y Rho3/Rnd3; la subfamilia RhoBTB, con las proteínas RhoBTB 1, 2 y 3; y la recientemente descrita subfamilia Miro. Además existen otras tres proteínas que 
pertenecen a esta familia pero que aún no han podido ser clasificadas dentro de ninguna de estas subfamilias: RhoD, Rif y TTF/RhoH ${ }^{1}$ (Fig. 2).

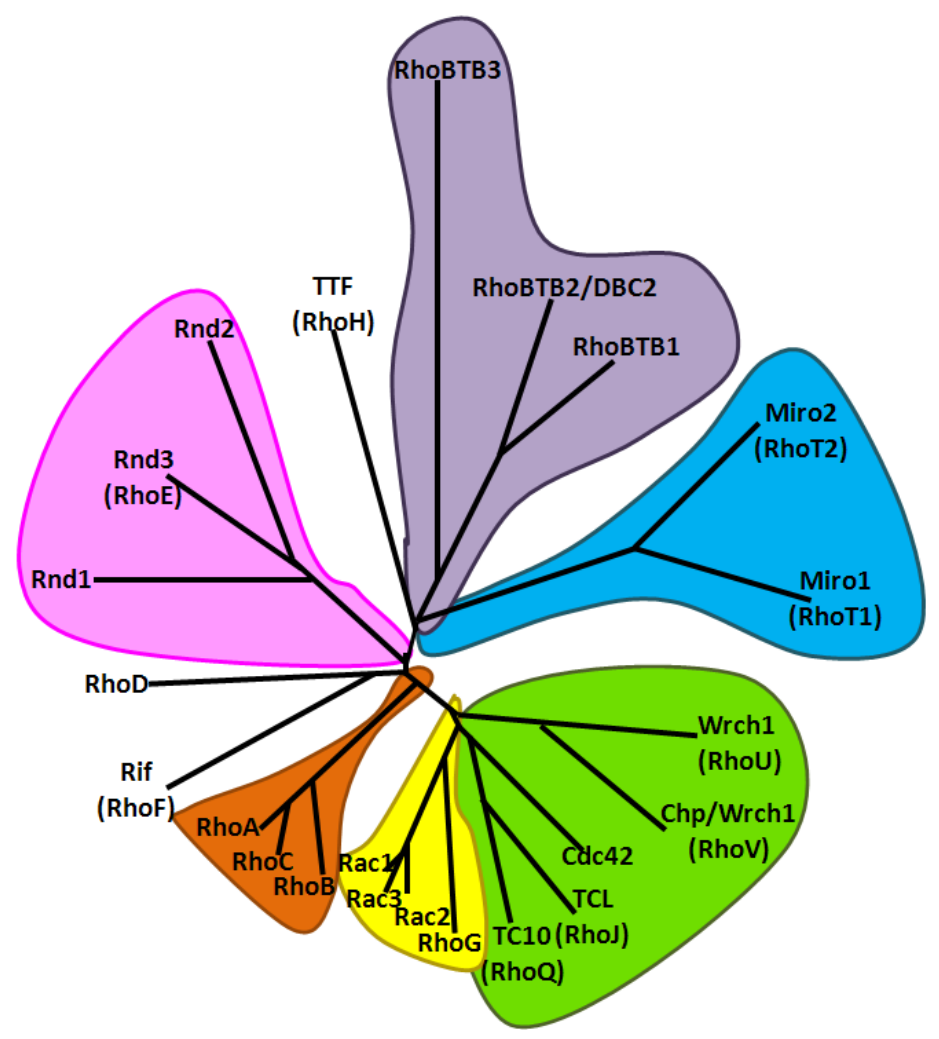

Figura 2: Distribución de la familia de proteínas Rho, que incluye seis subfamilias: Rho, Rac, Cdc42, Rnd, RhoBTB y Miro; y tres proteínas sin clasificas, TTF (RhoH), RhoD y Rif (RhoF). (Figura modificada de Ellenbroek y Collard, $2007^{4}$ ).

Las Rho GTPasas se encuentran presentes en todos los eucariotas y actúan como "interruptores moleculares", ciclando entre un estado activo cuando están unidas a GTP y un estado inactivo cuando están unidas a GDP². El control de este ciclo es el principal mecanismo de regulación de estas GTPasas y está controlado por tres clases de proteínas reguladoras: los GEFs (Guanine nucleotide Exchange Factors), que estimulan el intercambio de GDP por GTP promoviendo el paso de la GTPasa a su conformación activa $^{3}$, las GAPs que estimulan la capacidad intrínseca de hidrólisis del GTP, lo que lleva a la formación de una molécula inactiva unida a GDP y los GDls (GDP-dissociation Inhibitors), reguladores negativos de las proteínas Rho GTPasas que actúan uniéndose a las GTPasas en su estado inactivo y bloqueando el acceso de los GEFs y la asociación de las GTPasas a las membranas ${ }^{5}$ (Fig. 3). 


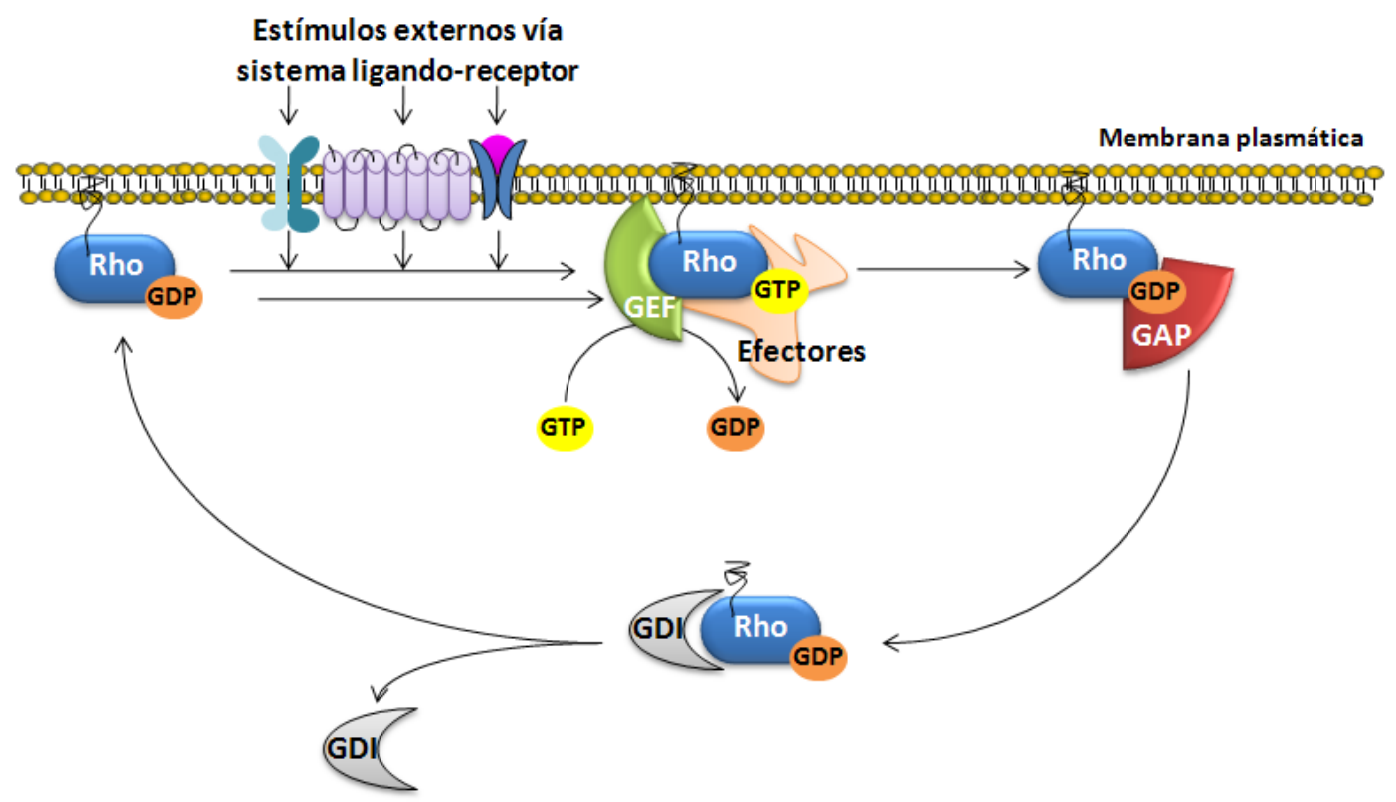

Figura 3: Ciclo de activación-desactivación de las Rho GTPasas. El reservorio de proteína Rho unida a GDP, es decir, en su forma inactiva, se encuentra en el citoplasma, secuestrado por las proteínas GDI, que impiden su activación por parte de los GEFs. La estimulación de la célula, ya sea por factores de crecimiento, moléculas de adhesión o integrinas, induce un reclutamiento de GEFs y la proteína Rho-GDP es transportada a la membrana plasmática. Los GEFs se encargan de estimular el intercambio de GDP a GTP, pasando la proteína Rho a su forma activa, pudiendo unirse a sus efectores para dar lugar a la activación de las cascadas de señalización aguas abajo. Las proteínas GAP favorecen la hidrólisis del nucleótido GTP a GDP, lo que lleva a la Rho GTPasa a pasar a su forma inactiva. Los GDIs se encargan de secuestrarla en este estado y llevarla al citoplasma.

La función principal de las GTPasas de la familia Rho, y la más estudiada, es la regulación del citosqueleto en respuesta a diversos estímulos extracelulares ${ }^{6-8}$. A través de esta regulación, las Rho GTPasas participan en el control de la morfología y polaridad celular, la migración y la endocitosis. Las proteínas Rho también están implicadas en la activación de factores de transcripción en respuesta a suero (SRF), que regulan la transcripción de numerosos genes implicados en la progresión del ciclo celular, el crecimiento y apoptosis ${ }^{9,10}$. Por último, también se ha descrito la participación de las Rho GTPasas en la regulación de diversas actividades enzimáticas, fundamentalmente enzimas implicadas en el metabolismo lipídico y la enzima NADPH oxidasa, implicada en la generación de radicales superóxido $(\mathrm{ROS})^{11}$. Resulta por lo tanto evidente que las Rho GTPasas tienen un papel fundamental en la biología celular. Esto explica que fallos en la regulación de su actividad den lugar a distintos estados patológicos humanos. Entre las 
entidades asociadas a alteraciones en las Rho GTPasas se encuentran enfermedades neurodegenerativas como la esclerosis lateral amiotrófica ${ }^{12}$, síndromes asociados con el retraso mental, alteraciones cardiovasculares ${ }^{13,14}$, inmunodeficiencias como el síndrome de deficiencia de $\operatorname{Rac} 2^{15-17}$ o el síndrome de Wiskott-Aldrich ${ }^{18}$, infecciones bacterianas ${ }^{19,20}$ y el cáncer ${ }^{1}$. Las alteraciones causantes de estas enfermedades pueden aparecer a nivel de las Rho GTPasas, de sus proteínas reguladoras o de sus efectores. El estudio realizado en esta tesis doctoral se centra en determinar las alteraciones en el gen CHN2 que puedan contribuir a estados anómalos de activación de la GTPasa Rac.

\section{La GTPasa Rac.}

La GTPasa Rac1 fue originalmente descrita como una proteína de la superfamilia Ras sustituta de la toxina botulínica C3 (Ras-related C3 botulium toxin) ${ }^{21}$. Pertenece a la familia Rho GTPasa y presenta una gran homología con otras proteínas de su familia como RhoA y Cdc42, con una alta conservación de los aminoácidos necesarios para la unión e hidrólisis del GTP ${ }^{22}$.

Rac1 interacciona con efectores específicos a través de un dominio efector GTPasa. La especificidad en la interacción da lugar a la activación de múltiples cascadas de señalización implicadas en diversos procesos fisiológicos. Además de Rac1, existen otros miembros de la subfamilia Rac con una alta homología entre ellos. Rac1, Rac2 y Rac3 tiene una similitud de secuencia de aproximadamente el $88 \%$. Se diferencian fundamentalmente en 15 residuos de la zona C-terminal, denominada región hipervariable (Fig. 4). Todos los miembros de la subfamilia Rac estimulan la formación de lamelipodios y ondulaciones de membrana ${ }^{23}$.

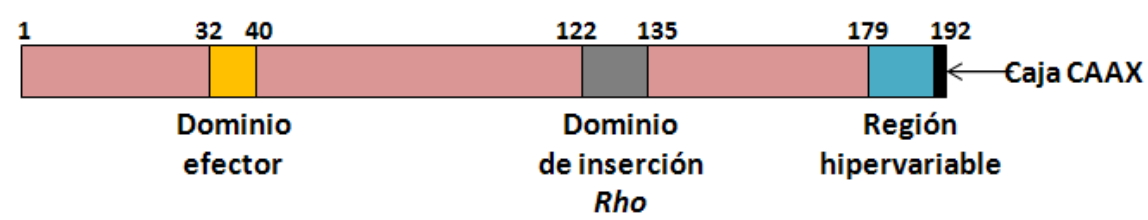

Figura 4: Representación esquemática de la secuencia de Rac1. La región hipervariable es la secuencia en la que más difieren las isoformas de Rac (1, 2 y 3 ) 
Mientras que la expresión de Rac1 es ubicua, Rac2 aparece sólo en células hematopoyéticas, donde parece tener funciones específicas ${ }^{21}$. Los ratones knock-out de Rac1 son letales a nivel embrionario ${ }^{24}$, mientras que los de Rac2 tienen un desarrollo normal pero presentan defectos en las células hematopoyéticas ${ }^{25}$. Muchos de esos defectos son posiblemente causados porque Rac2 activa específicamente la oxidasa $\mathrm{NADPH}^{26,27}$ y genera radicales superóxido ${ }^{28}$. Cuando se combinan las deficiencias en Rac1 y Rac2 en células hematopoyéticas, se observa que los defectos generados por ambas se enfatizan, pero también se pone de manifiesto los diferentes papeles que estas dos GTPasas tienen en estas células ${ }^{15}$.

La expresión de Rac3 es alta en cerebro, pero también aparece sobreexpresada bajo estimulación por suero en fibroblastos ${ }^{29}$. Rac3 se localiza en la membrana con una mayor presencia que Rac1 ${ }^{30}$. Esta proteína se ha encontrado hiperactivada en cáncer de mama $^{30}$, y el gen Rac3 está cercano a una región cromosómica del cromosoma 17 que se deleciona frecuentemente en cáncer de mama ${ }^{31}$, lo que puede desregular su expresión.

Existe una variante de Rac1, Rac1b, generada por inserción de un exón alternativo, que codifica 19 nuevos residuos en la región switch II de la región C-terminal de la proteína. Rac1b se expresa predominantemente en cáncer de mama y $\operatorname{colon}^{32,33}$. Esta proteína presenta un incremento en el intercambio de los nucleótidos de guanina y también presenta una disminución de la actividad GTPasa ${ }^{34,35}$, al no ser capaz de unirse a los GDIs aparece con más frecuencia en la membrana plasmática ${ }^{35}$. Estas características hacen que Rac1b se comporte, en general, como un Rac1 constitutivamente activado, pero con algunas propiedades de señalización diferenciales tales como que no es capaz de activar JNK, aunque conserva la capacidad para activar el factor de transcripción $N F K B^{35}$. Debido a su diferencia en la unión a efectores, presentando una afinidad muy reducida por la serina/treonina quinasa $\mathrm{PAK}^{34,35}$.

La proteína Rac1 interacciona con efectores específicos a través de dominios que coordinan la activación de múltiples cascadas de señalización que influyen en diversos procesos fisiológicos. El primer efector de Rac1 descrito fue la familia de quinasas activadoras de p21 (PAK). PAK se une a Rac1 cuando este está activo, es decir, unido a GTP, estimulando potentemente la actividad quinasa de PAK, lo que conduce a modificaciones en el citosqueleto, la adhesión y la transcripción ${ }^{36,37}$. La señal de Rac1, a 
través de PAK, estimula la actividad quinasa de JNK (Quinasas N-terminal de Jun) ${ }^{38}$, situando a Rac1 entre H-Ras y MEKK en la cascada de señalización que une la activación los receptores del factor de crecimiento con v-Src a través de la activación de JNK. Además, Rac1 a través de PAK puede influir en la actividad transmembrana guanilil ciclasa y en la producción del segundo mensajero $\mathrm{CGMP}^{39}$ y ejerce de mediadora en la señalización de Wnt regulada por JNK al factor de transcripción $\operatorname{TCF}^{40}$. Se ha demostrado que Rac1 también influye en la señalización nuclear a través de los efectores MLK 2/3, que, se ha visto, activan la ruta $\mathrm{JNK}^{41,42}$.

La señal de Rac1 puede ser importante en la transformación celular a través de la modulación de la apoptosis y la maquinaria del ciclo celular. Rac1 regula positivamente la transcripción de los genes regulados por promotores dependientes del factor de transcripción $\mathrm{NFKB}^{43}$ y facilita la activación dependiente de la fosfatidilinositol-3P quinasa de la quinasa AKT serina/treonina ${ }^{44-47}$; de ese modo, permite la supervivencia de las células transformadas. Rac1 también puede influir en la transformación a través de la regulación de la ciclina D1, una proteína del ciclo celular sobreexpresada en cáncer ${ }^{38,48}$. Por consiguiente, Rac1 es un componente crítico de una compleja red de señalización que, directa o indirectamente, impacta en una amplia selección de señales celulares.

\section{II.1. FUNCIONES DE RAC1.}

La proteína Rac interviene en multitud de procesos celulares, actuando en lugares específicos en rutas de señalización muy complejas, en paralelo con otras proteínas Rho, de manera agonista o antagonista según el momento. Para poder realizar todas estas funciones de manera específica y refinada, Rac está regulada por una gran cantidad de proteínas GEFs, GAPs y GDIs, además de por su unión diferencial a un alto número de efectores.

Los miembros de la subfamilia Rac intervienen en múltiples respuestas celulares como la modulación de cambios citosqueléticos, la estimulación de cambios transcripcionales, la progresión del ciclo celular, la morfogénesis y la diferenciación de las células. Se encargan, además, de regular respuestas biológicas específicas de determinados tipos celulares, como la producción de radicales libres en neutrófilos, la fagocitosis de macrófagos, el crecimiento axonal de las neuronas o la formación de la 
sinapsis inmune en linfocitos $\mathrm{T}^{49}$. Se ha observado también la implicación de las proteínas de la subfamilia Rac en diversos procesos patológicos, lo que hace más relevante el conocimiento de su función y regulación.

\section{II.1.a. Regulación de la polimerización el citosqueleto de actina.}

A través de un estudio sobre fibroblastos quiescentes Swiss3T3, se describión ${ }^{23}$ la implicación de Rac1 en la regulación de la formación de las protrusiones ricas en F-actina o lamelipodios, así como de las ondulaciones de membrana. Posteriormente se ha observado la implicación de la subfamilia Rac en diversos procesos relacionados con el citosqueleto de actina tales como la fagocitosis, activando los cambios citosqueléticos necesarios para la internalización de partículas ${ }^{50,51}$; la pinocitosis, estimulando la formación de vesículas macropinocíticas dependiente del citosqueleto de actina ${ }^{23}$; la morfogénesis de distintos tipos celulares ${ }^{52-55}$; y migración celular ${ }^{44,56}$.

Un ejemplo de control de la morfogénesis por parte de la subfamilia de proteína Rac es la regulación del crecimiento del axón de las neuronas ${ }^{52,53}$. El control de la morfología mediado por la actividad de Rac sobre el citosqueleto de actina también se observa en la formación y estabilización de fotorreceptores de Drosophila ${ }^{57}$ o en la diferenciación a células cardiacas especializadas de células precursoras ${ }^{58}$.

La GTPasa Rac también interviene en la migración celular. Este proceso se inicia con la formación de un lamelipodio, una extensa protrusión que contiene una amplia red de filamentos de actina ramificados, que se encuentra en el frente de avance de las células. La forma activa de Rac se encuentra concentrada en este frente de avance estimulando la polimerización de actina y, además, inhibiendo la despolimerización ${ }^{56}$.

\section{II.1.b. Regulación de la transcripción.}

Rac1 está implicada en la regulación de la transcripción génica. Modula la transcripción de genes a través de la activación de NFkB, JNK y MAPK, que inducen la activación del factor de transcripción $\mathrm{AP}-1^{50}$. Estos factores de transcripción pueden regular la expresión de proteínas que controlan la progresión del ciclo celular, como la Ciclina D1 y c-Myc, induciendo la progresión de la fase G1 a la fase $S^{59,60}$. En células T, 
Rac1 está implicado en la estimulación del factor nuclear de células T activadas (NFAT) a través del factor de transcripción AP-1. Este proceso es crítico en la progresión del ciclo celular y la expansión clonal de los linfocitos antígeno-específicos correctos ${ }^{61}$.

\section{II.1.c. Otras funciones.}

Además de su papel en los procesos anteriormente descritos, las proteínas Rac poseen funciones reguladoras específicas.

Rac1 participa en la generación de radicales superóxido que regulan funciones como la activación de factores de transcripción, proliferación, transformación, apoptosis y respuesta inmune innata celular ${ }^{62}$. En células fagocíticas, Rac1 activa al complejo NADPH oxidasa, promoviendo la generación de radicales superóxido que actúan como mecanismos de defensa frente a microorganismos ${ }^{63}$. En fibroblastos quiescentes, la mitogénesis celular está regulada por Rac1, a través de la generación de $\operatorname{ROS}^{62}$.

Numerosos estudios apuntan a que diversas Rho GTPasas están implicadas en el transporte de vesículas. En el caso de Rac1, mutantes de este gen constitutivamente activos inhiben la endocitosis mediada por clatrina ${ }^{64}$. La inhibición se lleva a cabo a través de la vía de la synaptojanina2, una fosfatidilinositol fosfatasa que induce un desrecubrimiento de las vesículas de clatrina, probablemente eliminando el sustrato Ptdlns $(4,5) P_{2}^{65}$. Rac1 parece tener relación también con la endocitosis independiente de clatrina, probablemente a través de la familia de proteínas ARF GTPasas, reguladoras de la dinámica de la membrana ${ }^{66}$.

\section{II.2. ENFERMEDADES CAUSADAS POR ALTERACIONES EN LA RUTA DE RAC.}

El amplio espectro de procesos celulares regulados por la proteína Rac explica que la desregulación de esta vía, tanto por sobreactivación como por inactivación, origine la aparición de diversas alteraciones que pueden aparecer a nivel de las Rho GTPasas, de sus proteínas reguladoras GEFs y GAPs, de sus efectores o de otras proteínas que intervengan indirectamente en la ruta. Las alteraciones más conocidas en esta vía desencadenan en la aparición y desarrollo de tumorigénesis, pero la ruta de señalización de las Rho GTPasas también se ha visto implicada en otros procesos patológicos, por 
ejemplo, alteraciones en genes que codifican proteínas tanto reguladoras de Rac como efectoras, están asociadas con la enfermedades neurológicas. Mutaciones en los genes que codifican las proteínas Oligonefrina- $1^{67}$, una proteína GAP de Rac, ARHGEF6 ${ }^{68}$, GEF específico de Rac1 y Cdc42, o PAK3, efector de la subfamilia Rac ${ }^{69}$, están asociados con el retraso mental no sindrómico asociado al cromosoma X. Asimismo, se ha observado un incremento de la expresión de Rac1 y RhoG en la enfermedad de Tangier, un trastorno en el metabolismo de los lípidos que genera hipertrofia del hígado, del bazo y de las amígdalas $y$, en ocasiones, manifestaciones neurológicas ${ }^{70}$. Se ha identificado una mutación inactivadora con efecto dominante negativa en el gen RAC2 como causante de inmunodeficiencia neutrofílica ${ }^{16,17}$; la mutación encontrada reduce la capacidad de la proteína a unirse a GTP e inhibe la respuesta a $\mathrm{GEFs}^{71}$, lo que se traduce en una disminución de la quimiotaxis, una reducción de la producción de ROS y una reducción de la fagocitosis de los neutrófilos en respuesta a determinados estímulos.

\section{2.a. Infecciones bacterianas.}

La manipulación de las GTPasas Rho en una estrategia utilizada por las bacterias patógenas para evadirse de las defensas del huésped. Estos microorganismos usan, principalmente, dos aproximaciones a la hora de infectar un organismo: impedir su internalización y destrucción por parte de los fagocitos y entrar dentro de células epiteliales donde estarán protegidas del ambiente externo y podrán crecer y dividirse. Ambos procesos implican vías de endocitosis que requieren de la actividad de las proteínas Rho ${ }^{19}$. Existen tres tipos de toxinas bacterianas que alteran la ruta de señalización de la GTPasa Rac (Fig. 5). Las glucosiltranferasas (LCC: Large clostridium cytotoxins) de Clostridium spp. impiden la interacción entre la GTPasa y sus efectores, bloqueando la actividad GTPasa tanto intrínseca como inducida por GAP y reprimiendo la activación por GEFs, lo que inhibe la activación de la ruta de señalización aguas abajo ${ }^{72}$. La enterobateria Salmonella spp. genera dos tipos de toxinas. Las primeras (SopE) actúan como compuestos mímicos de proteínas GEF de Rac1 y Cdc42, activando las GTPasas, lo que conduce a la remodelación del citosqueleto de actina para favorecer la entrada de la bacteria. Las segundas (SptP, Salmonella spp.; YopE, Yersinia spp.) son toxinas mímicas de proteínas GAP de Rac1 que inactivan esta Rho GTPasa. Así la estructura del citosqueleto vuelve a su estadio original y la bacteria queda protegida dentro de la célula infectada ${ }^{20}$. 


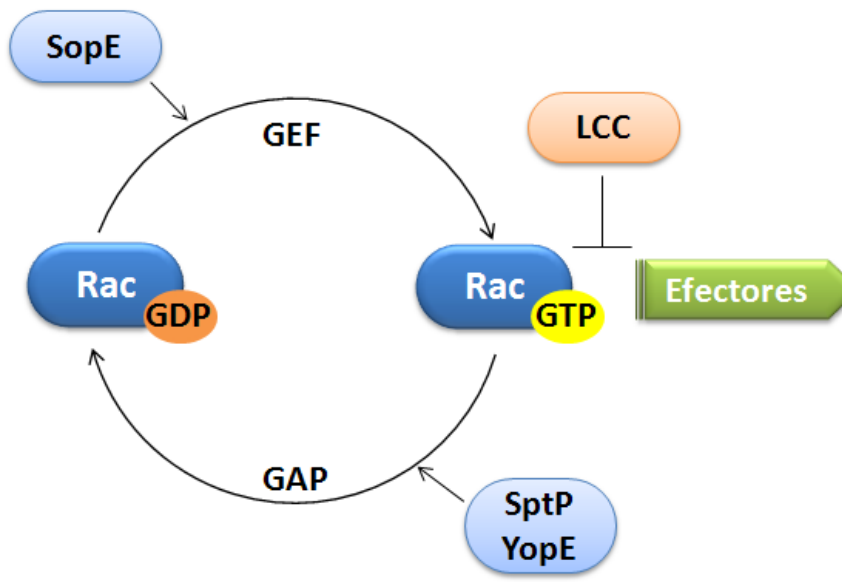

Figura 5: Mecanismos moleculares de las toxinas bacterianas que se unen a Rac. SopE actúa como un GEF, activando Rac. SptP y YopE, favorecen la hidrólisis de Rac-GTP al actuar como compuestos mímicos de proteínas GAP. LCC bloquea la interación de Rac activo con sus efectores.

\section{II.2.b. La GTPasa Rac y el cáncer.}

El término cáncer define a un grupo de enfermedades en las que las células crecen de manera anormal y acaban formando un tumor maligno. El cáncer se origina por dos procesos diferentes pero relacionados. Primero se produce la mutación de genes reguladores de la célula y, posteriormente, ocurre la selección clonal, es decir, la expansión del clon mutado debido al incremento de sus propiedades proliferativas y de supervivencia.

Las alteraciones que originan la aparición del primer paso pueden tener lugar en dos tipos de genes. Los oncogenes, que son genes mutados derivados de genes normales, los proto-oncogenes, cuya función normal es promover la proliferación y la supervivencia celular. Son factores de crecimiento, receptores de factores de crecimiento, proteínas de transducción de señales, factores de transcripción, reguladores del ciclo celular y reguladores de la apoptosis. El proceso de transformación maligna de una célula puede comenzar con una mutación en un alelo de uno de estos genes. Cuando la célula mutada prolifera, puede incorporar mutaciones adicionales. Las mutaciones de los oncogenes se consideran como mutaciones de ganancia de función porque producen una proteína más activa o porque aumentan la cantidad de proteína normal sintetizada. Los genes supresores de tumores codifican proteínas que inhiben la proliferación, promueven la muerte celular o reparan el DNA. Ambos alelos deben estar inactivos para que se 
produzca una pérdida de función de la proteína, lo que deriva en la transformación maligna de la célula.

Rac1, Rac2 y Rac3 aparecen sobreexpresados en varios tumores y existen múltiples evidencias que indican que la señalización celular dependiente de Rac es importante para la transformación maligna de las.

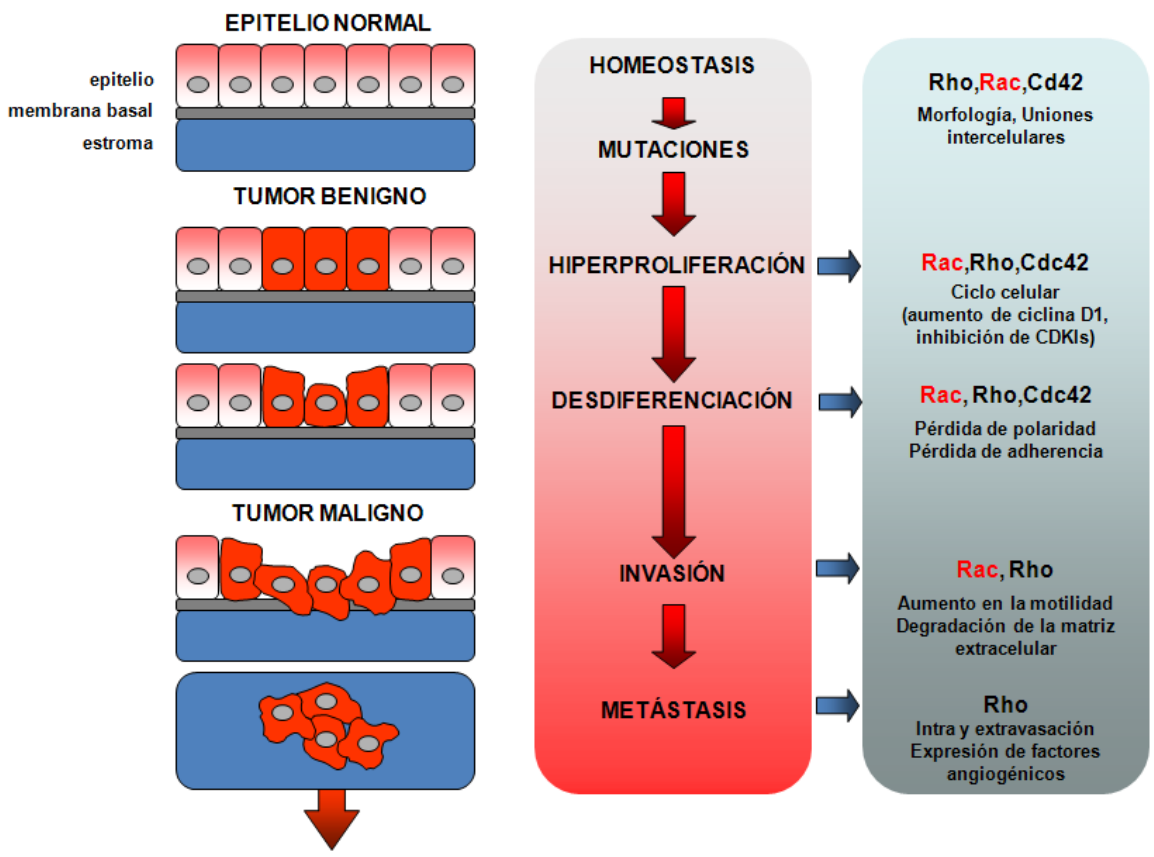

Figura 6: Esquema de la relevancia de las GTPasas Rho en la progresión tumoral, resaltando el papel de Rac en esta progresión.

La sobreexpresión de Rac1 está relacionada con la progresión de cáncer de testículo, gástrico y de mama. También se observa su sobreexpresión en carcinoma escamocelular bucal ${ }^{73}$. A través de ensayos de ratones knock-out condicionales de Rac1, se ha visto que esta proteína estimula la proliferación celular del tumor, pero inhibe su diseminación ${ }^{74}$. En un modelo de ratón knock-out condicional con cáncer de pulmón se vio que la función de Rac1 era necesaria para la proliferación y la tumorigenicidad inducida por K-Ras ${ }^{74}$. Del mismo modo, ratones carentes de la proteína GEF específica de Rac, Tiam1, están protegidos frente al cáncer de piel inducido por Ras, desarrollando menos tumores, aunque son más agresivos ${ }^{75}$. Rac1 contribuye a la proliferación de las células cancerígenas a través de la regulación del ciclo celular, por ejemplo, estimulando la expresión de ciclina $\mathrm{D} 1^{76}$. Además, Rac1 activo media en la pérdida de las uniones 
adherentes entre células en determinadas situaciones, promoviendo una mayor migración celular ${ }^{77}$, pudiendo potenciar o inhibir la invasión celular del tumor dependiendo de las características de la célula. También puede contribuir a la invasión de células cancerígenas regulando la producción de la matriz de metaloproteasas y sus inhibidores naturales ${ }^{78}$. La variante de splicing de Rac1, Rac1b, aparece expresada en cáncer de mama y cólon ${ }^{32,33}$.

Las alteraciones no sólo pueden estar a nivel de la proteína Rac, sino que se han observado alteraciones en sus proteínas reguladoras GEFs, GDIs y GAPs, como las quimerinas.

\section{LAS QUIMERINAS.}

Existen alrededor de 80 proteínas con actividad RhoGAP ${ }^{4}$ englobadas en 12 subfamilias. Estas proteínas no sólo contienen un dominio GAP sino que, además, presentan elementos estructurales adicionales que les confieren propiedades regulatorias únicas tales como interacciones específicas proteína-proteína o proteína-lípido. Las quimerinas tienen la particularidad, dentro del grupo de las RhoGAPs, de ser las únicas que tienen un dominio GAP con actividad específica para $\operatorname{Rac}^{79,80}$ y un dominio $\mathrm{C} 1$ similar al de PKCs (Proteína quinasa C). Esta particularidad bioquímica y estructural les confiere la capacidad de actuar como efectores del DAG tras la activación de receptores de membrana y acoplar esa señalización con la activación de Rac.

\section{III.1. GENES DE LAS QUIMERINAS.}

La primera isoforma de las quimerinas fue clonada por Louis Lim et al en 1990 a partir de cDNAs de cerebro humano ${ }^{81}$, se denominó como $n$-quimerina o quimerina neuronal, aunque más tarde pasó a ser llamada $\alpha 1$-quimerina ${ }^{82,83}$. Existen cuatro miembros de la familia de las quimerinas: $\alpha 1-, \alpha 2-, \beta 1-$ y $\beta 2$-quimerinas. Estas isoformas son productos generados a partir de inicios alternativos de la transcripción de dos genes: el gen $C H N 1$, que codifica las formas a1- y a2-quimerinas; y el gen $C H N 2$, que codifica la $\beta 1$ - y $\beta 2$-quimerinas (Fig. 1). 
El gen de las $\alpha$-quimerinas de humanos (CHN1) se localiza en el locus 2q31-32.1 ${ }^{79}$, tiene un tamaño de $213 \mathrm{~kb}$ y posee 13 exones codificantes. A partir del ATG de inicio del exón 1 codifica la isoforma a2-quimerina (GenBank: NM_001822) de 2700 pb, que se traduce en una proteína de 459 aminoácidos y 53 kDa (GenBank: NP_001813). Además, este gen presenta un inicio alternativo de la transcripción 174 pb aguas arriba del inicio del exón 7, que genera un tránscrito de 1002 pb. Este mRNA codifica la isoforma a1quimerina, una proteína de 334 aminoácidos y 38 kDa, que difiere de la anterior en que carece del dominio SH2 en el extremo N-terminal y posee 58 aminoácidos diferentes en este extremo $\mathrm{N}$-terminal, codificados por la secuencia entre el inicio alternativo de la transcripción y el inicio del exón 7.

El gen de las $\beta$-quimerinas ( $C H N 2)$ se localiza en el cromosoma $7 p 15.3$ en humanos, posee también 13 exones y tiene un tamaño de $320 \mathrm{~kb}$. Al igual que el gen CHN1, posee un inicio de la transcripción en el exón 1, que genera la isoforma $\beta 2$ quimerina (GenBank: NM_004067) de 3447pb, que codifica una proteína de 468 aminoácidos y 54 kDa (GenBank: NP_004058). Por inicio alternativo de la transcripción en el intrón 6 se genera otra isoforma, ß1-quimerina (GenBank: NM_001039936), de 2843 pb. La proteína que codifica presenta una secuencia de 332 aminoácidos y un peso molecular de 38 kDa (GenBank: NP_001035025). Como ocurre con las $\alpha$-quimerinas, las isoformas difieren en la región $\mathrm{N}$-terminal careciendo, la isoforma $\beta 1$-, de la región codificada por los 6 primeros exones, pero poseyendo una secuencia codificante única de 168 pb (56 aminoácidos), que es considerada como intrónica, y por tanto, no codificante, en la isoforma $\beta 2$-quimerina (Fig. 7).

La $\boldsymbol{\alpha} 1$-quimerina se expresa mayoritariamente en cerebro $^{82}$, restringida a las neuronas. La expresión es elevada en las células piramidales del hipocampo, las células granulares del giro dentado y las neuronas corticales; en el cerebelo, el mRNA de la $\alpha 1$ quimerina sólo se detecta en las neuronas de Purkinje ${ }^{84}$. La isoforma $\boldsymbol{\alpha 2}$-quimerina presenta altos niveles de expresión en neuronas de regiones específicas del cerebro ${ }^{85}$. En organismos menos evolucionados, como el pez cebra, la expresión del gen homólogo a chn2 es elevada en cerebro y se detecta también en músculo y testículo. En rata, la expresión de la $\boldsymbol{\beta} 1$-quimerina se ha descrito restringida a testículo ${ }^{86}$. La expresión de la 
isoforma $\boldsymbol{\beta 2}$-quimerina es elevada en cerebelo y en células granulares ${ }^{80}$, y se expresa a diferentes niveles en prácticamente todos los tejidos ${ }^{87}$.

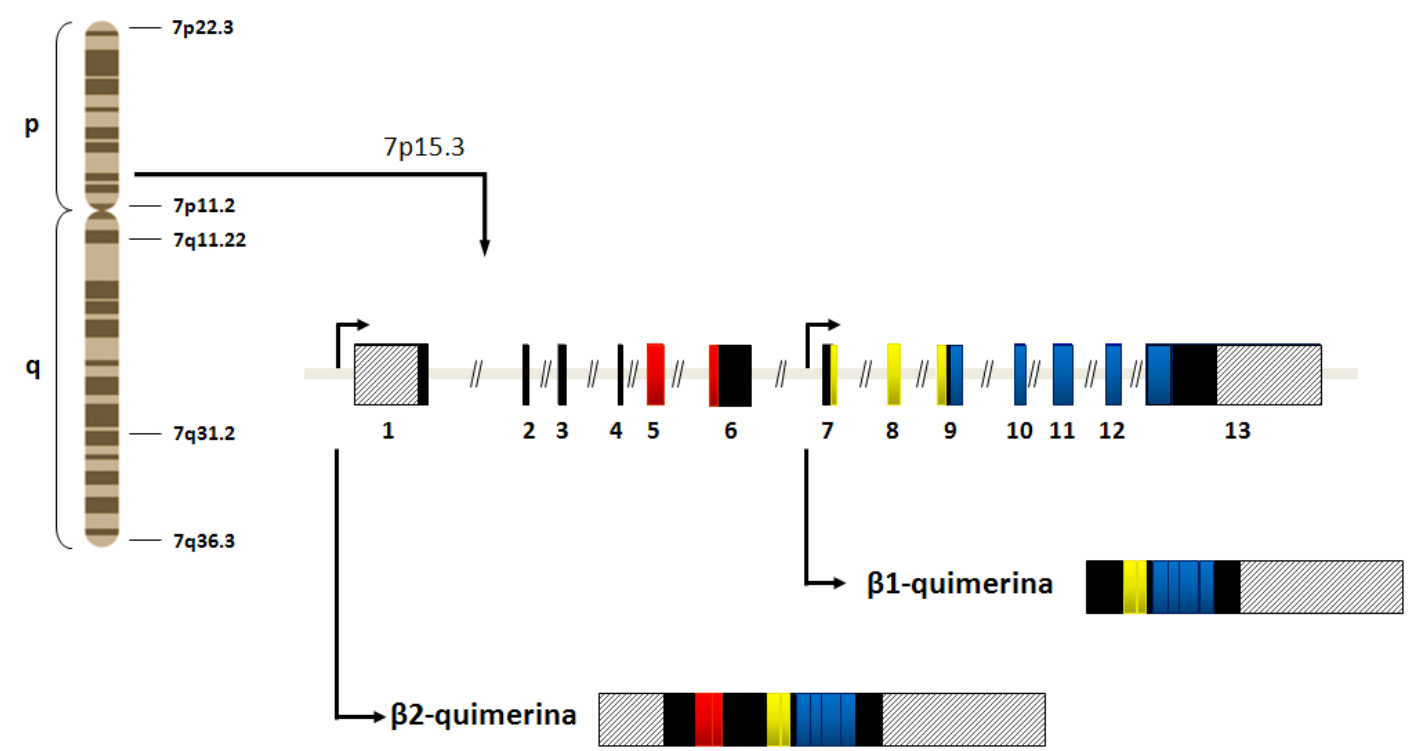

Figura 7: Estructura y localización cromosómica del gen CHN2. Tránscritos producidos dependiendo del inicio de la transcripción utilizado. $\beta 2$-quimerina tiene el inicio de la transcripción en el exón 1, mientras que $\beta 1$-quimerina se transcribe a partir del inicio localizado en el intrón 6.

Aunque los genes de las quimerinas fueron clonados hace más de dos décadas, los mecanismos que controlan la expresión de las proteínas son aún desconocidos. Dong y $\operatorname{Lim}^{88}$ demostraron que la expresión de la $\boldsymbol{\alpha 1} \mathbf{1 - q u i m e r i n a}$ en neuronas se regula espacial y temporalmente a nivel transcripcional. En la línea celular de neuroblastoma humano SK$\mathrm{N}$-SH, los niveles de mRNA de las formas $\alpha 1$ - y $\alpha 2$-quimerina aumentan durante la diferenciación neuronal. La despolarización de membrana inducida por $\mathrm{KCl}$ también produce un incremento de la expresión de la a1-quimerina en células SK-N-SH. Además, la expresión de la $\alpha 1$-quimerina se ha encontrado aumentada en respuesta a cambios hipotónicos de osmolaridad ${ }^{88}$. Estudios en diferentes estadíos embrionarios de rata confirman que los niveles de la proteína $\boldsymbol{\alpha 1 - q u i m e r i n a}$ aumentan en respuesta a la actividad sináptica ${ }^{89}$. El mRNA de la $\alpha 1$-quimerina de la rata se detecta en cerebro embrionario a partir del día 15 de la gestación y aumenta la cantidad desde el nacimiento hasta el día 20 , coincidiendo con la diferenciación celular y la sinaptogenesis ${ }^{84}$. Se ha demostrado que los niveles de proteínas de la a1-quimerina de rata en el tejido del hipocampo aumentan gradualmente durante las 2 primeras semanas del desarrollo 
postnatal, mientras que los niveles de la a2-quimerina presentan un pico de expresión a los 6 días del nacimiento, y luego decae ${ }^{89}$.

No obstante, aún se desconoce cómo se regulan las otras isoformas de las quimerinas. Hay evidencias de que disminuyen su expresión en algunos cánceres ${ }^{90,91}$. Estudios en la región promotora de la $\alpha 1$-quimerina revelan que no existen cajas TATA, ni sitios de unión a SP1 o motivos iniciadores; sin embargo, se observa una caja CCAAT localizada en la región próxima al promotor, que es esencial para su actividad ${ }^{92}$. Se ha encontrado un elemento de regulación negativo en la región 5'UTR no traducible del exón 1 de la $\alpha 1$-quimerina. La deleción de este elemento regulador aumenta de 5 a 6 veces la actividad del promotor $^{93}$. Por último, se ha observado la metilación de novo del gen CHN2 tras la inducción de tumores de hígado en un modelo de carcinogénesis química en ratones ${ }^{94}$, lo que sugiere que uno de los mecanismos de regulación de la expresión del gen CHN2 podría ser la metilación de su promotor.

\section{III.2. ESTRUCTURA Y PROPIEDADES BIOQUÍMICAS DE LAS QUIMERINAS.}

Las quimerinas deben su nombre a que fueron originariamente definidas como una quimera entre el dominio $\mathrm{C} 1$ de las PKCs y el dominio GAP de BCR, una proteína implicada en la traslocación del cromosoma Filadelfia en leucemia mieloide crónica. Las cuatro isoformas tienen un dominio C-terminal GAP y un dominio sencillo C1 como el de las PKCs. Las isoformas $\alpha 2$ - y $\beta 2$-quimerinas tienen, además, un dominio $\mathrm{SH} 2$ en el extremo amino terminal.

El dominio SH2 de la $\beta 2$-quimerina está codificado por parte de los exones 5 y 6 del gen CHN2 y comprende los aminoácidos 60 a 127. El dominio C1 está codificado entre los exones 7 a 9 y se sitúa entre los aminoácidos 214 a 264. La secuencia del dominio GAP aparece en los exones 9 a 13, incluyendo los aminoácidos 276 a 462 (Fig. 8). Esta distribución de los dominios es muy similar en la isoforma a2-quimerina.

\section{III.2.a. El dominio $\mathrm{SH} 2$}

$\alpha 2$ - y $\beta 2$-quimerina tienen un dominio SH2 terminal con una homología del $82 \%$ entre ellas ${ }^{80}$ (Fig. 9). Este dominio conserva las secuencias consenso de unión a 
fosfotirosinas común en otros dominios SH2 aunque, a diferencia del resto, el dominio SH2 de las quimerinas contienen un residuo de ácido glutámico al inicio en vez de triptófano y, comparado con otros dominios SH2 como el de la proteína Src, tiene una $\alpha$ hélice más corta ${ }^{80}$.

A

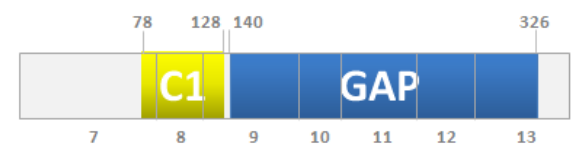

B1-quimerina

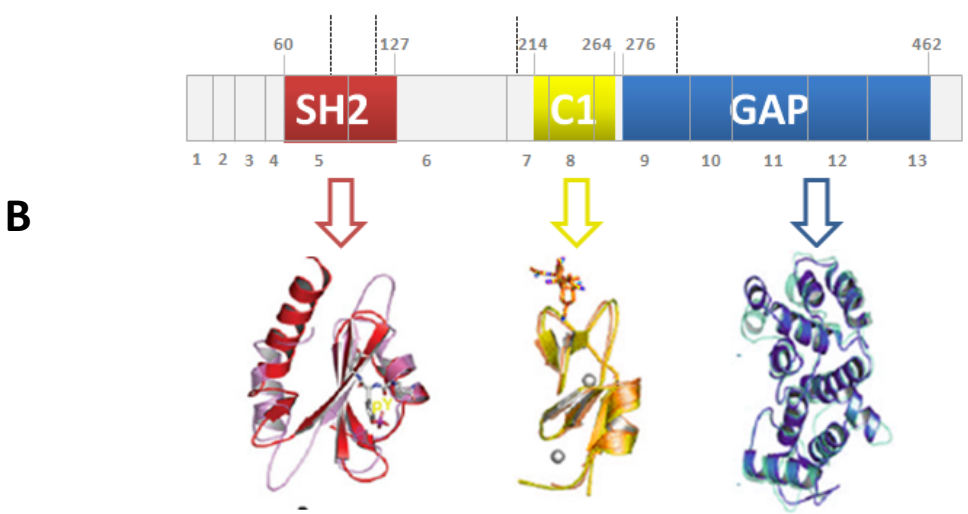

B2-quimerina

Figura 8: Estructura y composición de exones de los tránscritos del gen CHN2. (A) Exones que codifican cada isoforma. Aparecen señalados los dominios funcionales, los residuos en los que están codificados estos dominios. El exón 7 de la isoforma $\beta 1$-quimerina es de mayor tamaño que el de la $\beta 2$-quimerina porque el inicio de la transcripción alternativo que genera esta isoforma, ocurre en una región intrónica del gen. (B) Estructura tridimensional de los dominios funcionales de las quimerinas.

Se sabe muy poco sobre la función biológica de este dominio en quimerinas. Mientras otros estudios han demostrado que el dominio SH2 de RasGAP se une a receptores de factores de crecimiento $^{95}$, se desconoce si el dominio SH2 de $\alpha 2$ - y $\beta 2$ quimerina tiene propiedades similares. Estudios previos han demostrado que el dominio SH2 de la a2-quimerina interactúa con otras proteínas, y que esta interacción es necesaria para la neuritogénesis ${ }^{85}$. La expresión de la $\alpha 2$-quimerina con una mutación en el dominio SH2 en células PC12 estimuladas con NGF (Nerve growth factor) producen un fenotipo parecido al de la a1-quimerina e inhiben la formación de la neurita, sugiriendo que el dominio $\mathrm{SH} 2$ debe estar asociado con las proteínas que son críticas para la diferenciación neuronal ${ }^{85}$. Otros estudios han descrito un nuevo mecanismo de regulación negativa de la $\beta 2$-quimerina a través de la fosforilación de un residuo tirosina situado en el dominio $\mathrm{SH}^{96}$. Se ha encontrado que la tirosina 21 de la región reguladora 
$\mathrm{N}$-terminal se fosforila a través de la ruta SFK ( $\underline{S} r c$-family $\underline{\text { kinase) }}$ en respuesta a EGF (Epitelial growth factor). Utilizando tanto inhibidores de SFK como mutantes no fosforilables en Tyr21, se ha mostrado un nuevo mecanismo de regulación negativo de ß2-quimerina, a través de la fosforilación de la tirosina 21 mediado por SKF, ya que la inhibición de la fosforilación de esta tirosina es esencial para aumentar la actividad GAP de la $\beta 2$-quimerina ${ }^{96}$.

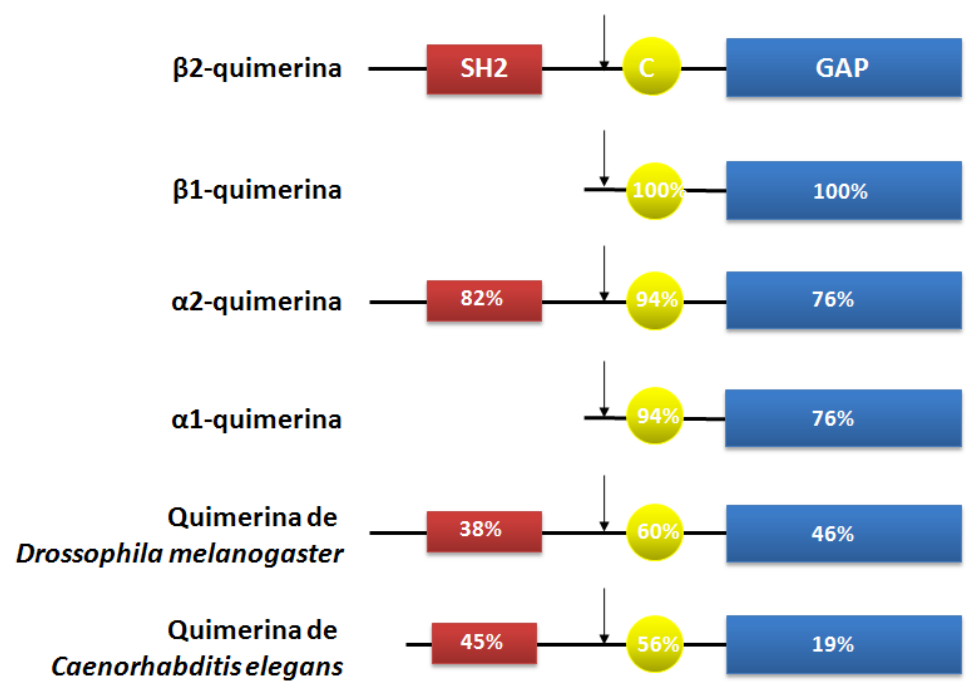

Figura 9: Comparación de la homología de secuencia entre las distintas proteínas que componen la familia de las quimerinas. Comparación de las formas humanas $\alpha 1-, \alpha 2-, \beta 1$ - y $\beta 2$-quimerina, y las quimerinas de Drossophila melanogaster y Caenorhabditis elegans. Los porcentajes de homología corresponden a la secuencia de cada dominio en relación con la isoforma $\beta 2$-quimerina.

III.2.b. El dominio C1 de quimerinas: las quimerinas como nuevos receptores de DAG.

El dominio $\mathrm{C} 1$ es una unidad estructural de 50 aminoácidos originalmente definida como un módulo de unión a lípidos en las isoenzimas PKCs. Durante mucho tiempo se creyó que las PKCs eran la única familia de receptores intracelulares del segundo mensajero lipídico diacilglicerol y sus análogos, los ésteres de forbol. Existen tres tipos de PKCs, las PKCs clásicas dependientes de calcio $(\mathrm{cPKC} \alpha, \beta \mathrm{I}, \beta \|$ y $\gamma)$, las PKCs noveles independientes de calcio ( $\mathrm{nPKC} \delta, \varepsilon, \eta$ y $\theta$ ) y las PKCs atípicas (aPKC $\zeta$ y PKC $\lambda / \imath$ ); estas últimas no responden a DAG y ésteres de forbol. El dominio C1 de unión a DAG y ésteres de forbol está duplicado en las PKCs de respuesta a DAG, pero presente en una única copia en otras moléculas como las PKDs (Proteína quinasa D), RasGRPs ( $\underline{\text { Ras quanine }}$ releasing-protein), DGKs (Diacilglicerol quinasas), c-Raf y Vav ${ }^{97,98}$. Sin embargo, sólo un subgrupo de estas proteínas con dominio C1 único es capaz de unirse al DAG y los ésteres 
de forbol con alta afinidad debido, principalmente, a los estrictos requerimientos estructurales necesarios para esta unión. La primera proteína en ser descrita como una proteína de unión a DAG y ésteres de forbol fuera de la familia de las PKCs fue la $\alpha 1-$ quimerina $^{99,100}$. Posteriormente, se encontraron otras que se han agrupado en los denominados nuevos receptores para el $D_{A G}{ }^{98,101}$ y que engloba, además de las quimerinas, a PKD, RasGRP1, 2 y 4, Munc-13 y las isoformas $\beta$ y $\gamma$ de DGK (Fig. 10).

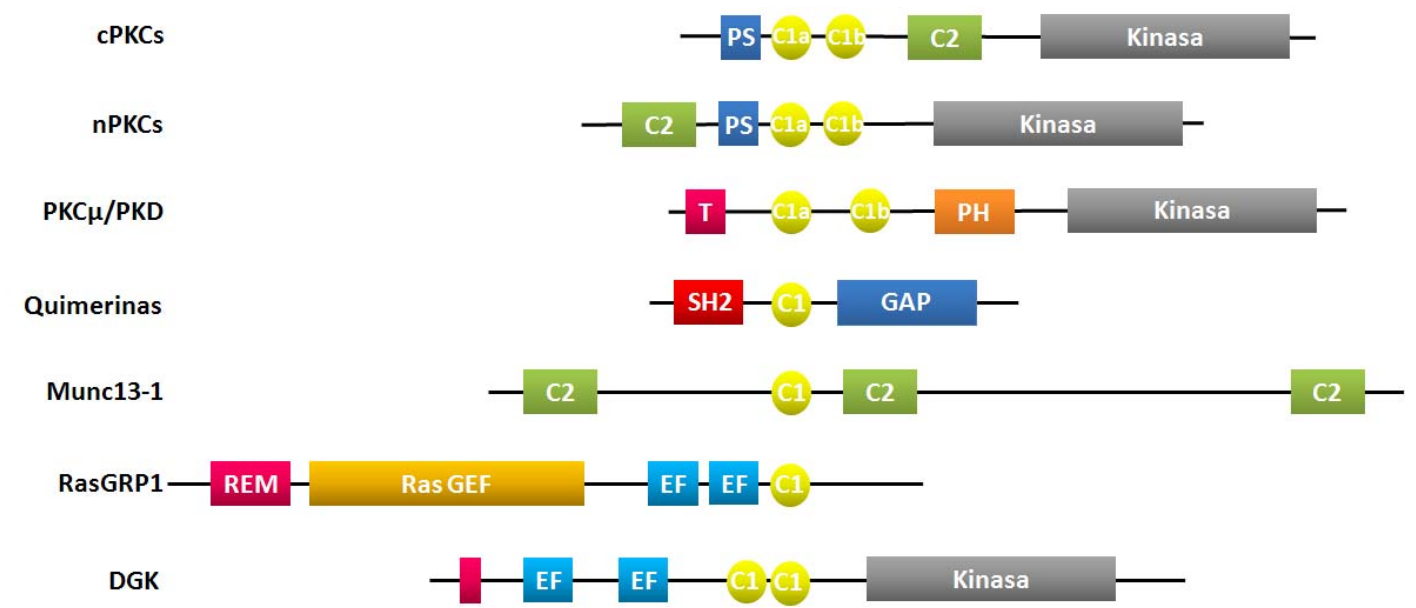

Figura 10: Estructura de las proteínas con dominios C1 de unión a ésteres de forbol y DAG. Las PKCs clásicas (cPKCs) y noveles (nPKCs) son los receptores clásicos de DAG. El resto de las proteínas se agrupan dentro de los denominados nuevos receptores para DAG.

Los dominios C1 tienen unos patrones únicos de reconocimiento del ligando debido a diferencias estructurales sutiles. El dominio C1 de las quimerinas tiene una homología del $40 \%$ con los dominios C1 de las isoenzimas PKC y posee todos los requerimientos estructurales necesarios para la unión a ésteres de forbol, manteniendo el motivo $\mathrm{HX}_{12} \mathrm{CX}_{2} \mathrm{CX}_{13 / 14} \mathrm{CX}_{2} \mathrm{CX}_{4} \mathrm{HX}_{2} \mathrm{CX}_{7} \mathrm{C}$ característico de los dominios $\mathrm{C} 1$ típicos. Como el inicio alternativo de la transcripción de los genes de las quimerinas ocurre aguas arriba del exón 7 , las isoformas $\beta 1$ - y $\beta 2$-quimerina presentan idéntico dominio $C 1^{79,80,86}$, al igual que sucede entre las isoformas $\alpha 1$ - y a2-quimerina. Los dominios C1 de la $\alpha$ - y la $\beta$ quimerina presentan homología del 94\% (Fig. 9).

La caracterización de las quimerinas como receptores de DAG/ésteres de forbol ha sido muy detallada. Se ha demostrado que el dominio C1 de las quimerinas une DAG y ésteres de forbol con alta afinidad y que esta unión es dependiente de la presencia de fosfolípidos acídicos pero es independiente de calcio, siendo en este aspecto similar a las PKCs noveles ${ }^{102}$. Por otro lado, análogos del DAG muestran una leve preferencia por $\beta 2$ - 
quimerina frente a PKCa ${ }^{103}$. De manera opuesta, thymeleatoxin, un promotor de tumores análogo de la mezereina, tiene una marcada preferencia por la unión a PKC $\alpha$ comparado con $\beta 2$-quimerina ${ }^{102}$. Existen, por tanto, similitudes importantes, pero también diferencias notables entre las quimerinas y las PKCs.

Además de estos estudios in vitro, experimentos en modelos celulares han demostrado que los ésteres de forbol y el DAG inducen la redistribución subcelular de las quimerinas ${ }^{103-106}$ y que esta regulación posicional, al igual que sucede con las PKCs, es enteramente dependiente del dominio $\mathrm{C}^{104}$. En conjunto, estos descubrimientos implican que las quimerinas actúan como efectores del DAG generado en respuesta a la activación de receptores.

\section{III.2.c. El dominio GAP: las quimerinas como reguladores de la GTPasa Rac}

El dominio GAP de las quimerinas está compuesto por 150 aminoácidos y tiene una elevada homología con el dominio GAP de BCR. El dominio GAP de las $\alpha$ - y $\beta$ quimerinas comparte el $77 \%$ de identidad ${ }^{86}$ (Fig. 9). Experimentos in vitro han demostrado que las quimerinas aumentan la hidrólisis de Rac1, pero no la de Cdc42 y $\operatorname{Rho}^{107,108}$. Esta especificidad se explica por los datos derivados de la estructura cristalina de la $\beta 2$-quimerina, que predice unas interacciones estéricas y electrostáticas desfavorables para la unión con Cdc42 y RhoA, impidiendo la actividad catalítica sobre estas GTPasas. Asimismo, esta estructura ha revelado que la arginina en posición 311 de ß2-quimerina actúa como un dedo de arginina, aminoácido necesario para la catálisis, característico de los dominios GAP, que se introduce dentro del sitio activo de Rac y directamente estabiliza el estado de transición para la hidrólisis del GTP ${ }^{109}$.

Ahmed et $a l^{110}$ observaron que la actividad RacGAP de la a1-quimerina está marcadamente estimulada por fosfatidilserina (PS) y ácido fosfatídico (PA) y que los ésteres de forbol pueden actuar en sinergia con PS y PA. Por otro lado, el ácido lisofosfatídico (LPA), los lípidos derivados del fosfatidilinositol (Ptdlns, PtdlnsP y PtdlnsP ${ }_{2}$ ) y el ácido araquinoico inhiben la actividad RacGAP de $\alpha 1$-quimerina. También se ha observado que las quimerinas y sus mutantes sin actividad GAP se unen a Rac1 con constantes de unión similares ${ }^{108}$. Esta unión es promovida por el PMA (Forbol 12- 
miristato 13-acetato) y la asociación es más estable durante más tiempo en los mutantes que carecen de actividad GAP ${ }^{111}$.

\section{III.2.d. Estructura tridimensional de la B2-quimerina y modelo de activación}

La resolución de la estructura cristalina de la $\beta 2$-quimerina ${ }^{109}$ ha permitido conocer mejor la regulación y función de las quimerinas. La $\beta 2$-quimerina es la única proteína completa con un dominio C1 con capacidad de respuesta a los ésteres de forbol cuya estructura terciaria se ha resuelto hasta el momento. Los datos de los análisis cristalográficos revelan que el dominio C1 forma amplios contactos hidrofóbicos con el dominio GAP y el dominio SH2. La zona $\mathrm{N}$-terminal de la $\beta 2$-quimerina se inserta dentro del sitio activo del dominio GAP, bloqueando estéricamente la unión de Rac. Además, el sitio de unión a DAG en el dominio C1 está sepultado por contactos con el dominio SH2, el dominio GAP y la región de unión de los dominios SH2 y C1. Estas características estructurales implican que, en la $\beta 2$-quimerina, el dominio C1 es inaccesible al DAG y los ésteres de forbol, y explica porqué se necesitan concentraciones más altas de ésteres de forbol para inducir la traslocación de la $\beta 2$-quimerina a las membranas que para la traslocación de las $\mathrm{PKCs}^{102,104}$. Por lo tanto, la unión de estos lípidos al dominio $\mathrm{C} 1$ de las quimerinas requiere de una disociación previa de estas interacciones intramoleculares, que permita la exposición del dominio $\mathrm{C} 1$ y la salida de la región $\mathrm{N}$-terminal del sitio activo para permitir la unión con Rac. Estos estudios estructurales se han confirmado utilizando mutantes de $\beta 2$-quimerina que desestabilizaban la conformación inactiva y presentan una mayor respuesta a ésteres de forbol, y también una mayor actividad RacGAP ${ }^{109}$.

Basados en estos hallazgos se ha propuesto un modelo de activación de las quimerinas $^{112}$ (Fig. 11). En condiciones basales, las quimerinas se encontrarían en una conformación autoinhibida en el citoplasma. Tras la estimulación de receptores que resultan en la generación de DAG, se produce un cambio conformacional que expone el dominio C1, facilitando la unión al ligando, la inserción en la membrana y la asociación con Rac, permitiendo así que se ejerza la actividad RacGAP de las quimerinas.

Aunque este modelo explica cómo se activan las quimerinas, no desvela cómo ocurren los cambios conformacionales. La predicción es que otros elementos, tales como 
modificaciones post-traduccionales, probablemente fosforilación, o interacciones con proteínas aún no identificadas, son necesarios para la transición hacia una conformación abierta. Tampoco está claro cuál es el papel que juega del dominio SH2 en la activación de las quimerinas. Se piensa que el dominio $\mathrm{SH} 2$ interacciona con proteínas fosforiladas en tirosina $y$, probablemente, también coopere con el dominio C1 en la asociación a membrana. Finalmente, este modelo describe la activación de las quimerinas exclusivamente en la membrana plasmática. Sin embargo, varios estudios muestran que las quimerinas se traslocan también a la región perinuclear, donde colocalizan con marcadores del aparato de Golgi y retículo endoplasmático ${ }^{104}$. Por lo tanto, cabe pensar que existan mecanismos de regulación alternativos en estos compartimentos intracelulares.

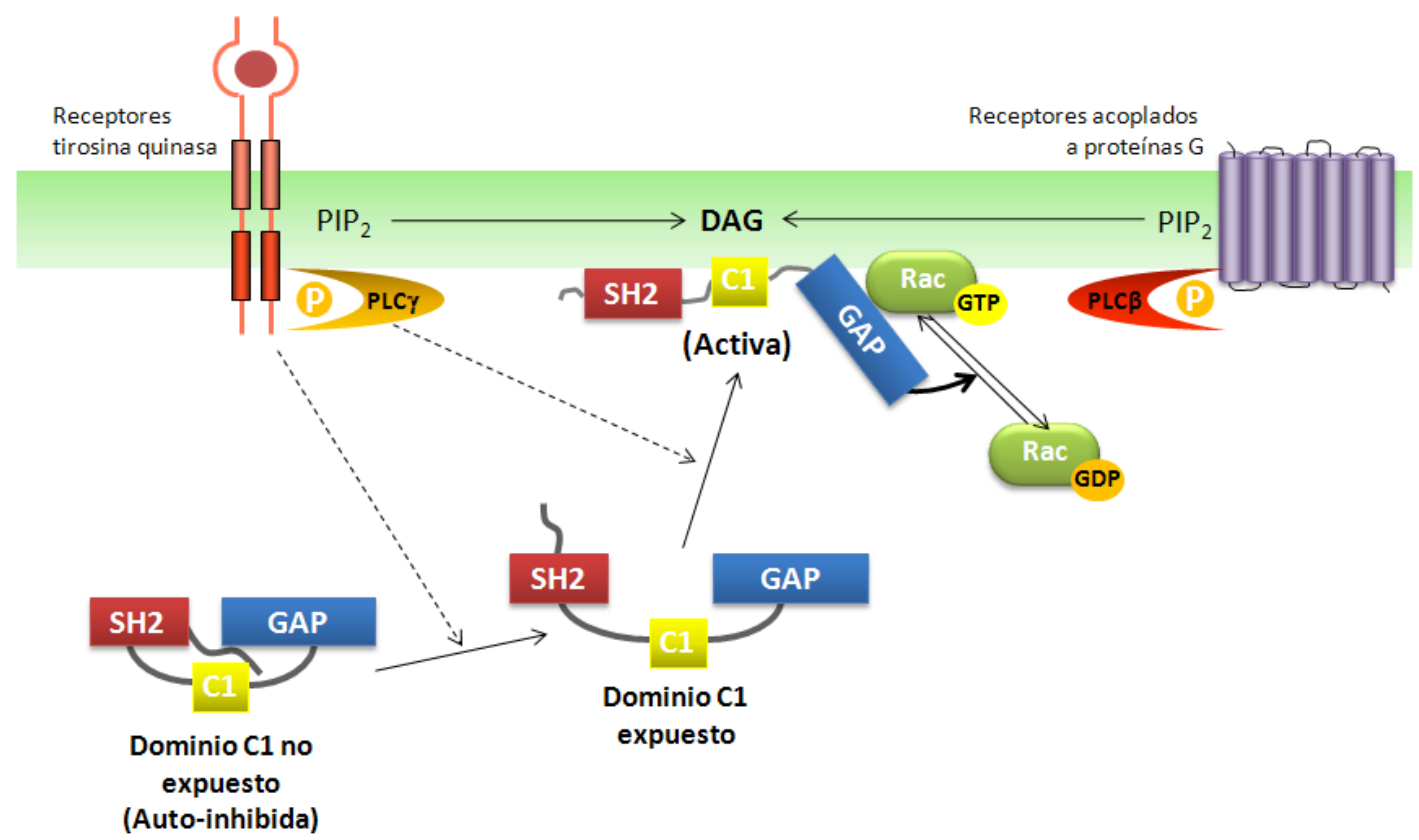

Figura 11: Modelo de activación de las quimerinas. Las quimerinas se encuentran en el citoplasma en estado inactivo. Tras la estimulación de receptore acoplados a la generación de DAG se desencadenan señales aún desconocidas que producen un cambio alostérico en la proteína, que deja expuesto el dominio C1. La proteína activa migra a la membrana, donde se une al DAG, se activa, y procede a la inactivación de Rac. (Modificado de Colón-González y Kazanietz. $2006^{113}$ ). 


\section{III.3. RUTAS DE SEÑALIZACIÓN REGULADAS POR LAS QUIMERINAS}

\section{III.3.a. Las quimerinas como efectores de receptores tirosina quinasa y GPCRs.}

Las quimerinas se activan por el DAG generado en respuesta a la estimulación de receptores y pueden tener un papel regulador importante en las rutas de señalización activadas por este segundo mensajero.

Varios estudios indican que la $\beta 2$-quimerina es un efector de EGFR (EGF receptor $)^{111}$. En células HeLa y COS, la estimulación con EGF induce la traslocación de $\beta 2$ quimerina desde el citoplasma a la membrana, la asociación con Rac y la consiguiente inactivación de esta GTPasa. La eliminación de la ß2-quimerina con RNAi aumenta significativamente la duración de la activación de Rac1 por EGF, sugiriendo que la $\beta 2$ quimerina sirve como mecanismo para limitar la actividad de Rac en respuesta a la activación de EGFR. Está claro que la activación de $\beta 2$-quimerina mediada por EGF es dependiente de DAG, puesto que se impide la traslocación de la $\beta 2$-quimerina tanto al delecionar la fosfolipasa $C_{\gamma}$ (PLC $\gamma$ ), proteína que genera DAG tras la estimulación del EGFR, como por mutación del dominio $\mathrm{C} 1$ de la quimerina. Se ha descrito un mecanismo muy similar para la isoforma $\alpha 2$-quimerina ${ }^{113}$. Estos resultados demuestran que la activación del eje PLC $\gamma$-DAG por receptores tirosina quinasa activa directamente proteínas RacGAP, lo que deriva en una atenuación de la señal de Rac (Fig. 11).

Además del EGFR, otra familia de receptores tirosina quinasas asociados a la activación de las quimerinas son los receptores de efrinas. La a2-quimerina se une al dominio quinasa del receptor EphA4 cuando está activado. En esta unión participa el dominio SH2 de la quimerina y otro sitio de unión adicional sin identificar. La activación del receptor EphA4 induce un rápido incremento de la fosforilación de las tirosinas de a2quimerina, incrementando su actividad GAP hacia Rac1. Esta regulación de Rac1 a través de la acción de $\alpha 2$-quimerina es fundamental en las neuronas motoras para modular el colapso del cono de crecimiento ${ }^{114-116}$. La $\alpha 1$-quimerina también puede unirse al receptor EphA4 pero, a diferencia de a2-quimerina, la unión no necesita que el receptor esté activo ${ }^{115}$. También se ha demostrado que la $\beta 2$-quimerina se une a los receptores EphA2 y EphA4. La unión al receptor EphA4 regula la actividad de Rac1 en respuesta a la estimulación de la efrina A1. Estos datos sugieren que la ß2-quimerina media en la 
inhibición de la migración celular inducida por la efrina A1 a través de la regulación de $\operatorname{Rac1}^{117}$.

Los GPCRs ( $\underline{G}$ protein-coupled receptors) pueden activar PLC $\beta$ y generar DAG a través de la vía de las proteínas heterotriméricas $\mathrm{G}_{\mathrm{q}}$. Estudios recientes utilizando CXCL12 (también conocido como factor derivado de las células del estroma-1 $\alpha$ o SDF-1 $\alpha$ ), una quimioquina estimuladora del crecimientos en linfocitos $\mathrm{B}^{118}$, muestran la primera evidencia de que las GPCRs también pueden modular la actividad de las quimerinas. CXCL12 promueve la traslocación de la $\beta 2$-quimerina en células Jurkat ${ }^{87}$ de manera dependiente de DAG. La capacidad de las GPCRs para regular la localización de las quimerinas vía DAG se ha demostrado también con mAChR1 (receptor de acetilcolina muscarínico 1), un receptor acoplado a $G_{q}-P L C \beta$. Estos estudios demuestran que la estimulación de mAChR1 recluta la isoforma $\alpha 1$-quimerina hacia la membrana plasmática de las neuronas del hipocampo en cultivo, proceso por completo dependiente de la generación de DAG y del dominio C1 de a1-quimerina ${ }^{89}$.

Además de los receptores tirosina quinasa y GPCR, las quimerinas actúan como efectores del TCR ( $\underline{T} \underline{c}$ ell receptor) y participan en el control de la activación del factor de transcripción NFAT tras la estimulación del TCR modulando, también, la actividad de $\operatorname{Rac}^{119}$.

\section{III.3.b. Interacción con otras proteínas}

La interacción de las quimerinas con otras proteínas se ha estudiado fundamentalmente en líneas celulares neuronales, donde la isoforma a1-quimerina interacciona con p35. Estas dos proteínas, junto con $\mathbf{C d k 5}$, forman un complejo proteico que, probablemente, participe en la coordinación del remodelamiento de los filamentos de actina de las neuronas ${ }^{120}$. Además, Brown et al ${ }^{106}$ demostraron que $\alpha 2$-quimerina activa interacciona con CRMP-2 (collapsin-response mediator protein-2) y Cdk5-p35 a través de sus dominio SH2 y GAP respectivamente. Más recientemente, Van de Ven et $a l^{121}$ describieron que la $\alpha 1$-quimerina está presente en dendritas y espinas neuronales, y que se une con la subunidad NR2A (NMDA [N-methyl-D-aspartate] receptor subunit $\underline{2 A}$ ), asociación necesaria para modular el número de espinas neuronales. Estos hallazgos 
sugieren que la actividad RacGAP de la $\alpha$-quimerina juega un importante papel de la regulación de las dinámicas del crecimiento de las neuritas.

Además de estas proteínas identificadas en neuronas, se ha descrito que Tmp21I, una proteína transmembrana localizada en la red cis-Golgi, interacciona con la quimerina $\beta 2$. La asociación de estas proteínas se produce tras la estimulación celular y es dependiente del dominio $C 1^{105,112}$ (Fig. 12). Tmp21-I es una proteína implicada en el tráfico intracelular, lo que sugiere la participación de las quimerinas el control de los mecanismos de transporte celular.

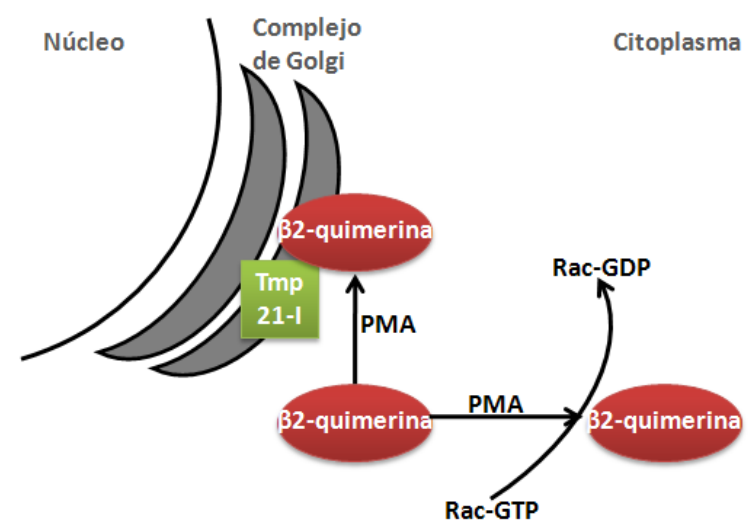

Figura 12: Modelo de interacción de la $\beta 2$-quimerina con Tmp21-I. La $\beta 2$-quimerina, tras su activación por PMA, se trasloca del citoplasma a la membrana plasmática, donde se encargará de la activación de Rac, o al complejo de Golgi, donde colocaliza con Tmp21-I. (Adaptado de Wang et $a l^{106}$ )

\section{III.4. FUNCIONES BIOLÓGICAS DE LAS QUIMERINAS.}

Las funciones biológicas de las quimerinas descritas hasta el momento están asociadas directamente con su capacidad de inactivar a Rac, participando en las funciones controladas por esta GTPasa: organización del citosqueleto y el ciclo celular, en varios sistemas celulares. Numerosas evidencias experimentales indican que las quimerinas inhiben estos efectos mediados por Rac.

\section{III.4.a. Quimerinas y el sistema nervioso}

La función mejor estudiada de las quimerinas es su papel como reguladores clave de la dinámica del citosqueleto en neuronas. Experimentos en modelos celulares 
demostraron inicialmente que las quimerinas $\alpha 1$ y $\alpha 2$ controlan la orientación del cono de crecimiento neuronal ${ }^{106,120,122}$ y modulan la densidad de las espinas dendríticas ${ }^{89,121}$. Estos resultados se han corroborado recientemente analizando ratones knock-out del gen chn1, que no expresan la proteína a2-quimerina por modificaciones en el exón 6 ( $\alpha 2$ quimerina $\left.^{-/}\right)^{114}$; otros que no expresan ni $\alpha 1$ - ni $\alpha 2$-quimerina $\left(\alpha \text {-quimerina }{ }^{-/}\right)^{115}$ por modificaciones en el exón 7, y ratones knock-in ( $\alpha$-quimerina ${ }^{\text {mut/mut }}{ }^{115}$ que presentan una mutación puntual con pérdida de función del dominio C1en ambas isoformas. Todos estos ratones presentan un fenotipo característico común; un trastorno de la marcha que se manifiesta con un movimiento simultáneo de las patas tanto delanteras como traseras, en vez de la alternancia característica entre el lado izquierdo y derecho ${ }^{114,115}$. Histológicamente todos los ratones transgénicos generados presentan un fallo en el entrecruzamiento de la neuronas motoras a nivel de la espina dorsal, que se produce por la alteración de la señalización mediada por los receptores de efrinas y el aumento de Rac activado en ausencia de las quimerinas ${ }^{123}$ (Fig. 13).

A

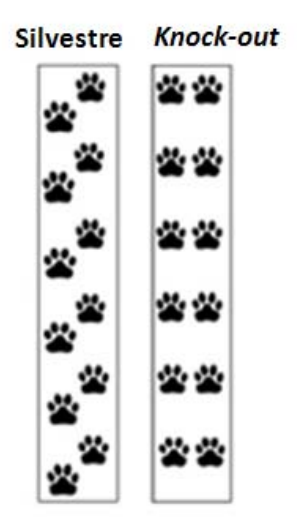

B

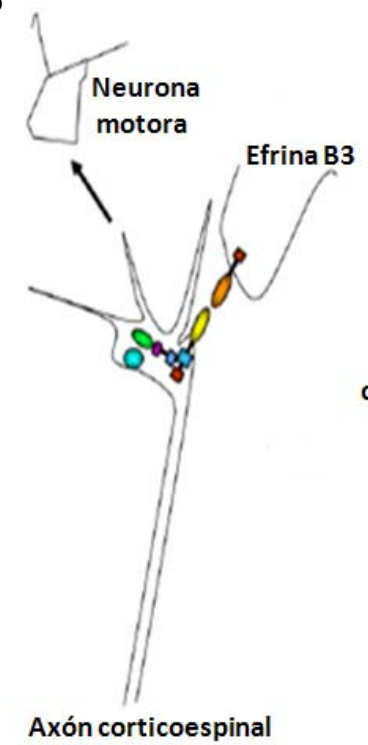

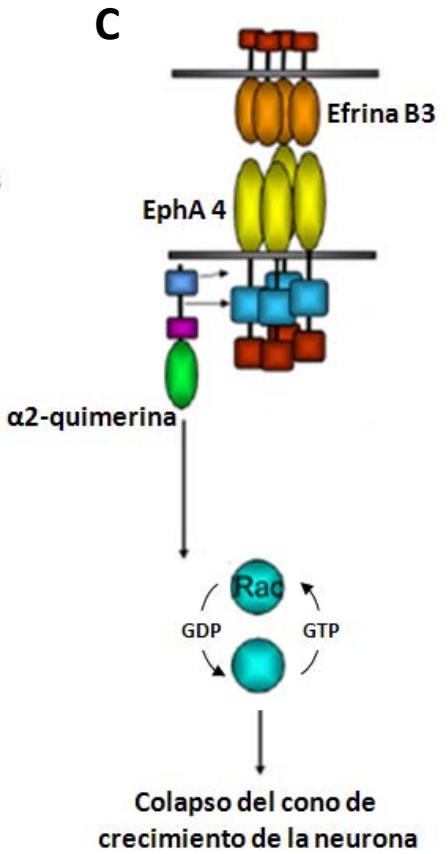

Figura 13: Modelo de la actividad de a2-quimerina en la señalización Efrina B3/EphA4. (A) LoS ratones knock-out de la EphA4 y de chn1 presentan el mismo fenotipo causado por defectos en las proyecciones axonales, un trastorno de la marcha que provoca que muevan las patas tanto delanteras como trasera simultaneamente en vez de alternativamente. (B) Conducción del axón mediado por la efrina B3 via EphA4 y a2-quimerina en el proceso axonal de la proyección de las neuronas corticales. (C) La efrina B3 se una al receptor EphA4. La a2-quimerina se una a EphA4 en presencia de la efrina B3 y su actividad RacGAP aumenta. La quimerina inactiva Rac induciendo el colapso del crecimiento del cono axonal. (Modificado de Dalva et al, $2007^{124}$ ). 


\section{III.4.b. Quimerinas y el sistema inmune.}

Se ha descrito recientemente la expresión de $\alpha 2$ - y $\beta 2$-quimerina en linfocitos $\mathrm{T}^{124,125}$. En estas células tienen un papel inhibitorio en el contexto de las señales mediadas por el TCR, regulando negativamente la activación del factor de transcripción $\mathrm{NFAT}^{87,119}$. Además, la traslocación de las quimerinas a la sinapsis inmunológica sugiere que estas proteínas también participan en la señalización que se genera tras formarse los conjugados entre la célula presentadora de antígeno y la célula T. Además de estas funciones asociadas a la activación del TCR, se ha demostrado que la $\beta 2$-quimerina participa en el control de la migración y adhesión dependiente de quimioquinas $\mathrm{T}^{119}$, poniendo de nuevo de manifiesto la importancia de las quimerinas en el control de la reorganización del citosqueleto mediada por Rac.

\section{III.4.c. Quimerinas y desarrollo.}

La función de las quimerinas durante el desarrollo embrionario se ha observado utilizando un knock-down del gen chn1 en pez cebra. El producto de este gen tiene una alta homología con la isoforma $\alpha 2$-quimerina de mamífero. Los embriones knock-down de chn1 muestran anomalías graves, progresan más rápidamente hacia epibolia y la mayoría de los embriones mueren antes del día $5^{87}$.

\section{III.5. ENFERMEDADES ASOCIADAS CON ALTERACIONES DE LAS QUIMERINAS.}

Existen varias enfermedades que están potencialmente asociadas con un funcionamiento anómalo de las quimerinas. El ejemplo más claro es el síndrome de retracción de Duane, compleja afección congénita autosómica dominante del movimiento de los ojos causada por una inervación anómala de los músculos extraoculares por los axones de las neuronas motoras ${ }^{126}$. Miyake et $a l^{127,128}$ encontraron mutaciones de cambios de sentido en el gen CHN1, que se asociaban con el desarrollo de la enfermedad. Las mutaciones aparecen a lo largo de toda la secuencia codificante del gen, afectando tanto al plegamiento de la proteína a2-quimerina. Todas las mutaciones descritas hasta el momento confieren a la proteína una ganancia de función que se ve reflejada en una mayor actividad RacGAP y un aumento de la eficiencia de traslocación a membrana ${ }^{129}$. La isoforma $\beta 2$-quimerina también podría participar en la aparición de 
trastornos neurológicos; así, se ha observado que el alelo $G$ del polimorfismo c.611A>G (p.H203R) (rs3750103) del gen CHN2 se asocia con la susceptibilidad a padecer esquizofrenia ${ }^{129}$.

En un estudio de diabetes familiar se observó una traslocación cromosómica de novo $[\mathrm{t}(7 ; 19)(\mathrm{p} 15.2 ; \mathrm{p} 13.2)]$ que interrumpe los genes INS y $C H N 2$, produciendo una haploinsuficiencia y, por tanto, una disminución de su expresión. Los pacientes presentaban resistencia a la insulina, que sería explicada por la haploinsuficiencia del gen INS, y problemas de desarrollo pre y postnatal, probablemente debido a los problemas en el gen $C H N 2$. En un estudio de asociación genética relacionada con la nefropatía diabética se describieron 21 genes, entre los que se encontraba el gen CHN2 significativamente asociados con esta enfermedad ${ }^{130}$. También se ha postulado que la $\beta 2$-quimerina puede ser relevante en la aterogénesis al participar en el control de la migración y la proliferación de las células de músculo liso vascular ${ }^{131}$. Por último, existen evidencias sugieren que $\beta 2$-quimerina desempeña un papel importante en la transformación maligna.

\section{III.6. LAS QUIMERINAS Y EL CÁNCER.}

Está ampliamente aceptado que Rac y otras proteínas Rho GTPasas juegan papeles críticos en la regulación de la morfología, movimiento y proliferación celular, eventos cuya desregulación es crucial para el desarrollo del cáncer y su progresión ${ }^{132}$. Rac1 y su variante de splicing, Rac1b, están sobreexpresadas o hiperactivadas en varios tipos de cáncer en humanos ${ }^{133}$. Naturalmente, la regulación negativa de la actividad de Rac ha sido explorada como terapia en la lucha contra el cáncer ${ }^{32,33}$. Es razonable hipotetizar que las quimerinas, como otras RhoGAPs, poseen capacidades como proteínas supresoras de tumores, y una acumulación de evidencias apoya esta hipótesis.

La primera asociación entre las quimerinas y el cáncer se describió en un estudio para identificar genes con expresión diferencial en tejido normal y astrocitomas de bajo grado en comparación con glioblastomas ${ }^{134}$. Este estudio reveló la disminución de la expresión de $\beta 2$-quimerina en glioblastomas, descubrimiento que respalda el papel de esta proteína como gen supresor de tumores e implican que la desregulación de la 
actividad de Rac puede jugar un papel en la progresión de los cánceres cerebrales humanos (Fig. 14A).

Así mismo, los niveles de mRNA de $\beta 2$-quimerina en tumores y en líneas celulares de cáncer de mama de humanos son significativamente menores que en tejido y células normales, sugiriendo el papel de las quimerinas en la supresión tumoral ${ }^{90}$. Apoyando esta hipótesis, la transfección del dominio GAP de $\beta 2$-quimerina en células de carcinoma de mama de ratón reduce los niveles de proliferación y la capacidad invasiva de las células tumorales in vitro ${ }^{91,135,136}$. En esta misma línea, la expresión ectópica de $\beta 2$-quimerina induce la parada del ciclo celular en fase $G_{0} / G_{1}$ e inhibe la proliferación de las células de cáncer de mama MCF-7 de manera dependiente de la actividad RacGAP. La reducción de los niveles de Rac-GTP por expresión de las quimerinas en estas células se correlaciona con la disminución de la expresión de ciclina D1, reducción de los niveles de fosforilación de pRb (proteína Retinoblastoma) e inhibición de la transición de $\mathrm{G}_{1}$ a $\mathrm{S}$ en el ciclo celular $^{136}$ (Fig. 14B.)

A Glioblastomas

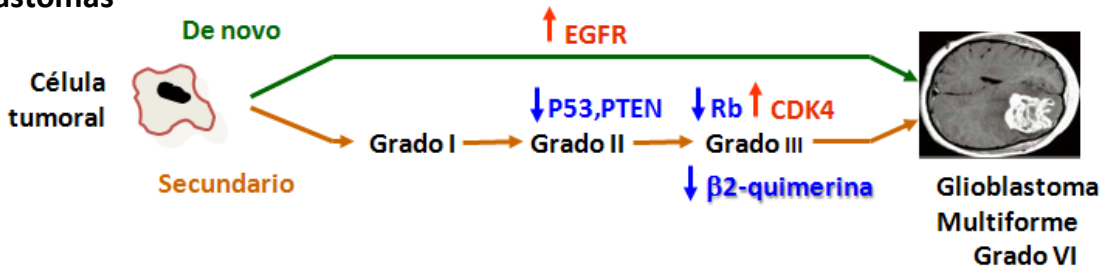

B Cáncer de mama

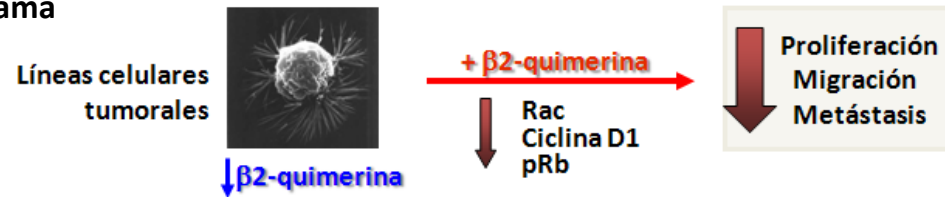

C Drossophila

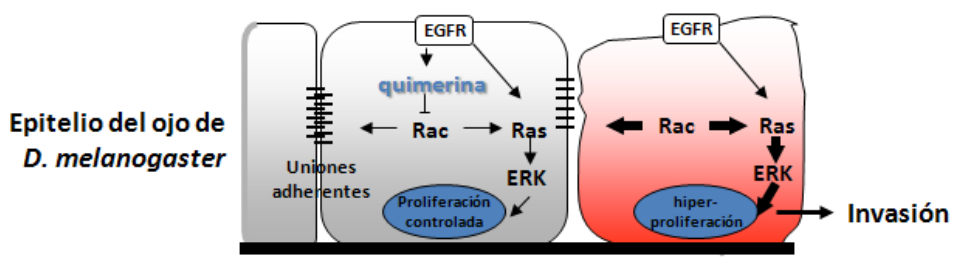

Figura 14: Resúmen gráfico de los estudios de la $\beta 2$-quimerina y su asociación con cáncer. (A) Mientras que los tumores de novo del sistema nervioso central presentan aumento de EGFR, los tumores secundarios presentan, entre otras variaciones, disminución de la expresión de $\beta 2$ quimerina. (B) En cáncer de mama también se observa disminución de la expresión. Cuando se sobreexpresan en líneas celulares tumorales la $\beta 2$-quimerina, se aprecia una disminución de la proliferación, migración y metástasis de estas líneas cancerígenas. (C) La eliminación de la expresión de la $\beta 2$-quimerina en células del epitelio ocular de $D$. melanogaster hace que las células pierdan las uniones adherentes y favorecen la invasión. 
Se ha señalado el papel crucial de Rac como mediador de la respuesta a factores de crecimiento en cánceres de mama. EGF y HRG (Heregulina $\beta$ ) causan aumentos significativos en los niveles de Rac-GTP en las líneas de cáncer de mama MCF7 y T-47D, y promueven la migración de las células de cáncer de mama y la proliferación de una manera dependiente de Rac1. A diferencia de EGF, el efecto de HRG sobre la actividad de Rac se mantiene. $\beta 2$-quimerina inhibe la migración y proliferación inducidas por HRG en células de cáncer de mama a través de la inactivación de Rac, señalando un papel de esta proteína ß2-quimerina en la interrupción de la respuesta dependiente de Rac mediada por factores de crecimiento ${ }^{91,135}$.

No existen en la actualidad estudios en modelos de mamíferos que analicen el papel supresor de tumores de las quimerinas. Sin embargo, un estudio realizado en Drosophila apoya esta función. El epitelio del ojo de Drosophila se ha utilizado como un modelo para estudiar el desarrolllo del cancer porque es un epitelio en el que se puede analizar facilmente la proliferación y adhesion celulares, y la señalización desde EGF a la ruta de ERK es muy importante. La eliminacion del único gen que codifica las quimerinas en Drosophila produce un aumento de la proliferación celular por activación de la ruta de ERK y se generan uniones intercelulares aberrantes, cambios que son consistentes con la transición a un fenotipo tumoral ${ }^{137}$. Este hallazgo situa de nuevo a las quimerinas como una molecula clave en en control de la activación de Rac mediada por EGF (Fig. 14C). 

HIPÓTISIS Y OBJETIVOS 



\section{HIPÓTESIS}

La $\beta 2$-quimerina, codificada por el gen $\mathrm{CHN2}$, tienen funciones de regulación negativa de la Rho GTPasa Rac. Del correcto equilibrio entre la proteína Rac activa e inactiva dependen multitud de procesos celulares, y su desregulación está implicada en diversas enfermedades como el cáncer.

Existen numerosos ejemplos de GEFs de las Rho GTPasas que son oncogenes (Vav, Trio, LARG, Dbl). Es por tanto lógico pensar que las proteínas GAP, en oposición a los GEFs, puedan actuar como genes supresores de tumores. De hecho, existen varios ejemplos de proteínas GAP con esta función. El más conocido es NF1, proteína GAP específica de Ras cuya inactivación produce neurofibromatosis ${ }^{138}$. Dentro de las proteínas

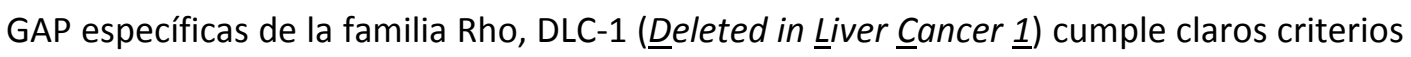
de gen supresor de tumores. Está localizado en el cromosoma 8p21-22 en humanos, una región cromosómica que se deleciona frecuentemente en algunos tipos de cáncer como el de mama, colon, hígado, pulmón y próstata ${ }^{139}$. Además, se observa disminución de la expresión de esta proteína en diversos tejidos tumorales respecto a tejido sano. Otros ejemplos de genes RhoGAP implicados en el desarrollo de cáncer son el gen GRAF, que aparece delecionado o mutado en el síndrome mielodisplásico; $B C R$, cuyo dominio GAP de la proteína se pierde en las proteínas de fusión $B C R-A B L$ producidas tras la traslocación y formación del cromosoma Filadelfia; y el gen RhoGAPp190, localizado en una región que se deleciona y recombina en gliomas y astrocitomas ${ }^{140} 141$.

En el caso de las quimerinas, los datos descritos en el apartado anterior apoyan la hipótesis de que la disminución de la actividad de estas proteínas en tumores no es un hecho meramente circunstancial sino que las quimerinas, en concreto la isoforma $\beta 2$, son una de las múltiples moléculas implicadas en la transformación maligna. Sin embargo, no existe ningún estudio que corrobore la función de estas proteínas como supresores de tumores.

Para que las alteraciones en un gen supresor de tumores deriven en un proceso tumorigénico, normalmente debe cumplirse la hipótesis del doble impacto de Knudson ${ }^{142}$. Esta teoría implica que ambos alelos del gen deben estar afectados antes de que el proceso tumorigénico se manifieste. Se necesita el silenciamiento completo del gen para 


\section{Hipótesis y Objetivos}

que el proceso cancerígeno ocurra ya que en condiciones de haploinsuficiencia, el alelo normal suple la carencia del alelo alterado. Existen múltiples alteraciones en un gen supresor de tumores. La aparición de alteraciones cromosómicas en un locus genético que incluye un gen supresor de tumores es una de las alteraciones más frecuentes. Además, es común que aparezcan mutaciones inactivadoras y alteraciones epigenéticas que silencian el gen. Los estudios que analicen la existencia de estas alteraciones en el gen $C H N 2$ son prácticamente inexistentes.

\section{OBJETIVOS.}

Ante estas premisas, y teniendo en cuenta los datos expuestos en la Introducción, el objetivo general de este trabajo se centró en analizar la presencia de alteraciones en el gen CHN2 que pudieran asociarse con la aparición y desarrollo de cáncer.

1. Búsqueda de mutaciones patogénicas del gen $C H N 2$ en muestras de tumor de distintos tipos de cáncer.

2. Análisis de los niveles de transcripción del gen CHN2 en líneas celulares cancerígenas.

3. Estudio de los mecanismos de regulación del promotor del gen CHN2: metilación del promotor. 
MATERIAL Y MÉTODOS 



\section{Plásmidos.}

La forma salvaje de la GTPasa Rac1 subclonada en el vector de expresión pCEFLAU5 fue obsequio del Dr. P. Crespo (Departamento de Biología Molecular, Unidad de Biomedicina de la Universidad de Cantabria-CSIC, Santander). El vector de expresión codificando el dominio de unión a GTPasa (dominio RBD: $\underline{R} a c$ - $\underline{\text { binding }}$ domain) de PAK1 fusionado a GST (pGEX-PAK1RBD) fue obtenido del Dr. R. A. Cerione (Cornell University, Itaca, NY, EE.UU).

Los vectores de expresión para las isoformas completas $\beta 2$ y $\beta 1$ de las quimerinas así como las isoformas truncadas ( $\beta 2-\mathrm{CHNdel}$ ex4-6, $\beta 2-\mathrm{CHNdel}$ ex6p-12pB, $\beta 1-\mathrm{CHNdel}$ ex7p y $32-C H N d e l$ ex7p11) se generaron mediante la amplificación a partir del gen CHN2 de los fragmentos correspondientes por PCR anidada. Para ello, se realizó una primera PCR con oligonucleótidos externos sobre el cDNA del tránscrito correspondiente ( $\beta 2$ y $\beta 1)$. Se utilizaron $0,5 \mu \mathrm{L}$ del producto de esta PCR como molde para la segunda PCR, en la cual se utilizaron oligonucleótidos más internos en los que se incluyó la secuencia de la enzima de restricción EcoRI. Los oligonucleótidos utilizados en cada caso se indican en la tabla 1. Las condiciones de PCR fueron $55^{\circ} \mathrm{C}$ de anillamiento, 40 ciclos y 2 ' de extensión.

Tabla 1: Oligonucleótidos y condiciones de PCR utilizados en la amplificación por PCR anidada de los tránscritos del gen CHN2. (F: Forward; R: Reverse).

\begin{tabular}{|c|c|c|c|}
\hline Oligonucleótido & Nombre PCR & Secuencia & $\begin{array}{c}\text { Producto de la } \\
\text { PCR }\end{array}$ \\
\hline$\beta 2-e x-F$ & \multirow{2}{*}{$\begin{array}{l}\beta 2-\mathrm{CHN} \\
\text { externa }\end{array}$} & 5' - GCT GAG CGA GCA GCG ACG CGA G - 3' & \multirow{2}{*}{$\begin{array}{l}1492 \mathrm{pb} \text { Anidada } \\
\beta 2 \text { externa }\end{array}$} \\
\hline$\beta-e x-R$ & & 5' - CTG TGT CAA CTT GGA TGG TGC - 3' & \\
\hline$\beta 1-e x-F$ & \multirow{2}{*}{$\begin{array}{l}\beta 1-\mathrm{CHN} \\
\text { externa }\end{array}$} & 5' - GGT TCG AAA ATC CTG ACA GCA CAG - 3' & \multirow{2}{*}{$\begin{array}{l}1125 \text { pb Anidada } \\
\beta 1 \text { externa }\end{array}$} \\
\hline $\boldsymbol{\beta}$-ex-R & & 5' - CTG TGT CAA CTT GGA TGG TGC - 3' & \\
\hline$\beta 2$-in-Eco-F & \multirow{2}{*}{$\begin{array}{l}\text { ß2-CHN } \\
\text { Anidada }\end{array}$} & $5^{\prime}$ - GAA TTC GCG TCC AGC AAC TCC AG - 3' & \multirow{2}{*}{$\begin{array}{l}1419 \text { pb Anidada } \\
\beta 2 \text { interna }\end{array}$} \\
\hline$\beta$-in-R & & 5 - GCG GAA TTC TTA GAA TAA AAC GTC TTC GTT - & \\
\hline B1-in-Eco-F & \multirow{2}{*}{$\begin{array}{l}\text { B1-CHN } \\
\text { Anidada }\end{array}$} & $5^{\prime}$ - GAA TTC TCT GAA GAA CTG TGG C - 3' & \multirow{2}{*}{$\begin{array}{l}1006 \mathrm{pb} \text { Anidada } \\
\beta 1 \text { interna }\end{array}$} \\
\hline$\beta$-in-R & & 5'- GCG GAA TTC TTA GAA TAA AAC GTC TTC GTT - & \\
\hline
\end{tabular}

Tras la amplificación, clonamos las PCRs específicas correspondientes a los distintos tránscritos en el vector $p G E M-T^{\circledR}$ Easy (Promega) (Fig. 15A). Las reacciones de ligación fueron utilizadas para la transformación de la cepa bacteriana competente $D H 5 \alpha$, 
que se sembró en placas de LB-Agar con IPTG y X-Gal para seleccionar los clones positivos por reacción colorimétrica. Una vez comprobada la secuencia de los clones, los fragmentos de interés fueron digeridos con la enzima EcoRI y ligados en los vectores de expresión pEGFP-C2 y pCEFL-FLAG (Fig. 15B y C), previamente cortados con EcoRI y defosforilados. La extracción del DNA plasmídico de las bacterias se realizó con el Kit Rapid DANA plasmid miniprep (GeneDan S.L.) o con el Kit PerfectPrep Endofree Plasmid Maxi kit (5'PRIME) cuando los plásmidos se utilizaron para la transfección de células eucariotas.

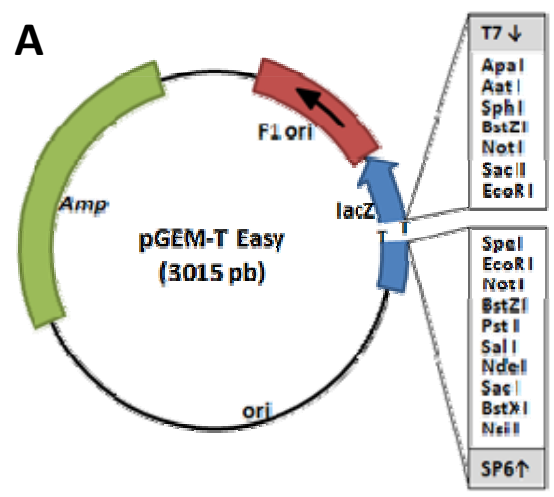

B

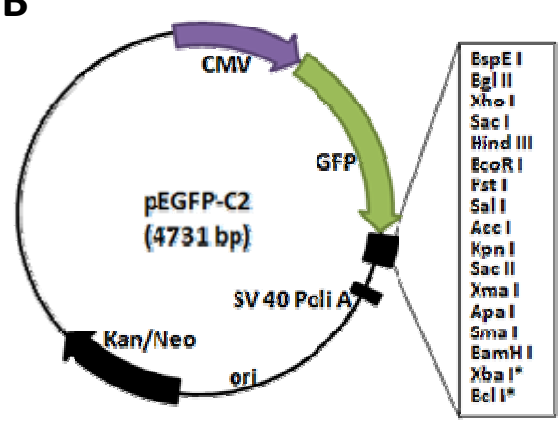

C

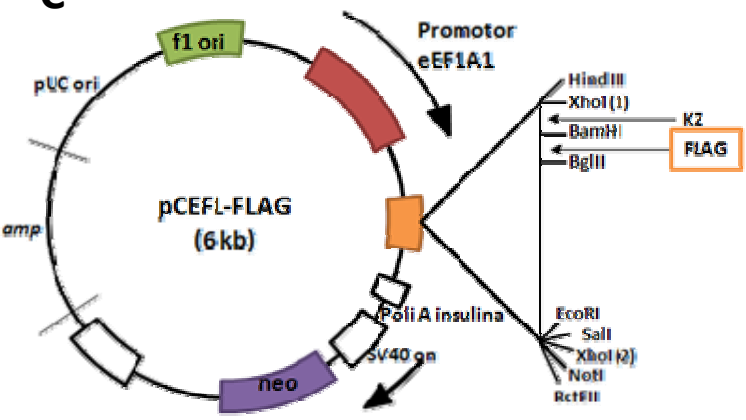

Figura 15: Esquema de los vectores de clonación utilizados en este trabajo. (A) Vector de clonación pGEM ${ }^{\circledR}$-T Easy (Promega). Presenta un operón LacZ, que se interrumpe al insertarse el producto de PCR tras la ligación (selección por color). (B) pEGFP-C1. El epítopo utilizado por este vector es la proteína verde fluorescente EGFP (Enhanced Green Fluorescent Protein) situada en el extremo 5' de la secuencia. (C) pCEFL-FLAG. En 5' del polilinker se situa la secuencia correspondiente al epítopo FLAG.

\section{Líneas celulares y condiciones de cultivo.}

Se utilizaron las líneas celulares que se indican en la Tabla 2. Todos los cultivos celulares se realizaron a $37{ }^{\circ} \mathrm{C}$ en atmósfera húmeda con un $5 \%$ de $\mathrm{CO}_{2}$. Los medios de cultivo empleados se especifican en la tabla. Todos los medios se suplementaron con un 
10\% de suero fetal bovino (FBS) y 1\% de penicilina-estreptomicina (Cambrex), a excepción del medio MEGM para el cultivo de las células MCF10A, que se suplementó con suero de caballo, insulina, EGF e hidrocortisona ${ }^{143}$. Todas las células utilizadas presentan una morfología epitelial y un crecimiento adherente a la placa.

Tabla 2: Características de las líneas celulares utilizadas en este trabajo. Los datos fueron extraídos de las bases de datos ATCC y DMSZ.

\begin{tabular}{|c|c|c|c|c|}
\hline Procedencia & Línea celular & Código ATCC & Tipo celular & Medio de cultivo \\
\hline \multirow{12}{*}{$\begin{array}{l}\text { Glándula } \\
\text { mamaria }\end{array}$} & AU565 ${ }^{144}$ & CRL-2351 & Adenocarcinoma. & RPMI 1640 \\
\hline & BT-474 ${ }^{145}$ & HTB-20 & Carcinoma ductal invasivo. & RPMI 1640 \\
\hline & BT-549 ${ }^{146}$ & HTB-122 & Carcinoma ductal invasivo, papilar. & RPMI 1640 \\
\hline & MCF10A $^{147}$ & CRL-10317 & Cultivo de glándula mamaria sana. & MEGM $^{\circledR}$ BulletKit \\
\hline & HS578T ${ }^{144}$ & HTB-126 & Carcinoma. & DMEM \\
\hline & LY2 ${ }^{148}$ & - & Carcinoma ductal invasivo. & DMEM \\
\hline & HBL100 ${ }^{149}$ & - & $\begin{array}{l}\text { Células tumorigénicas de mama sana, } \\
\text { productora de leche. }\end{array}$ & RPMI 1640 \\
\hline & MCF7 $^{150}$ & HTB-22 & Carcinoma ductal invasivo. & DMEM \\
\hline & MDA-MB415 $^{151}$ & HTB-128 & Adenocarcinoma. & DMEM \\
\hline & HCC2185 ${ }^{152}$ & - & Carcinoma lobular metastásico. & RPMI 1640 \\
\hline & HCC1569 ${ }^{153}$ & CRL-2330 & Carcinoma metastásico primario. & RPMI 1640 \\
\hline & HCC1937 ${ }^{153}$ & CRL-2336 & Carcinoma ductal primario. & DMEM \\
\hline \multirow{6}{*}{ Cerebro } & SH-SY5Y ${ }^{154}$ & CRL-2266 & Neuroblastoma. & DMEM \\
\hline & LN-443 ${ }^{155}$ & - & Glioblastoma. & DMEM \\
\hline & A $172^{156}$ & CRL-1620 & Glioblastoma. & DMEM \\
\hline & T $898^{157}$ & - & Glioblastoma. & DMEM \\
\hline & LN-229 ${ }^{158}$ & CRL-2611 & Glioblastoma. & DMEM \\
\hline & LN-18 ${ }^{159}$ & CRL-2610 & Glioblastoma. & DMEM \\
\hline Riñón & COS-1 & CRL-1650 & Fibroblastos. & DMEM \\
\hline
\end{tabular}

\section{MANIPULACIÓN DE LOS ÁCIDOS NUCLEICOS.}

\section{III.1. EXTRACCIÓN DE DNA Y RNA.}

\section{III.1.a. Extracción de DNA.}

Para la extracción de DNA de sangre periférica, se utilizaron $10 \mathrm{ml}$ de sangre periférica que se obtuvo por procedimientos rutinarios en el Hospital Universitario de Salamanca. La sangre se recogió en tubos con EDTA y se mantuvo $4^{\circ} \mathrm{C}$ hasta su procesamiento, que se realizó dentro de las primeras 24 horas tras la extracción. 
Las células mononucleadas se recogieron de la interfase obtenida tras centrifugar la sangre a 1500-2000 g. A continuación se añadió agua bidestilada estéril para provocar la lisis osmótica de los eritrocitos arrastrados en el paso anterior. El botón celular, que contiene únicamente las células nucleadas, se resuspendió en tampón FORNACE (0.25 M Sacarosa; $50 \mathrm{mM}$ Tris- $\mathrm{HCl}$ pH7.5; $25 \mathrm{mM} \mathrm{KCl} ; 5 \mathrm{mM} \mathrm{MgCl}$ ) al que se añadió $10 \mathrm{mM}$ de EDTA, $50 \mathrm{mg} / \mathrm{ml}$ de proteinasa $\mathrm{K}$ y $1 \%$ de SDS, y se incubó a $55^{\circ} \mathrm{C}$ durante $8-16$ horas. El DNA se purificó por el método de extracción de DNA con fenol y cloroformo descrito por Chomczynski y Sacchi ${ }^{159}$. El DNA se precipitó con alcohol absoluto, se lavó con etanol al $70 \%$ y se resuspendió en agua bidestilada. Este DNA en disolución se almacenó a - $20^{\circ} \mathrm{C}$.

Las muestras de tejidos fueron recogidas en el Hospital Universitario de Salamanca y se conservaron a $-80^{\circ} \mathrm{C}$ hasta su utilización. Para obtener el DNA, las muestras de tejido se homogeneizaron en tampón FORNACE utilizando un Politron. Al tejido homogeneizado se le añadió EDTA $10 \mathrm{mM}$, proteinasa $\mathrm{K} 50 \mathrm{mg} / \mathrm{ml}$ y SDS $1 \%$, incubándose la mezcla a $55^{\circ} \mathrm{C}$ durante 8-16h. El DNA se purificó por el método de extracción de DNA con fenol y cloroformo como se indica anterior.

Las células en cultivo en una placa de $10 \mathrm{~cm}$ con una confluencia del $90 \%$ se lavaron con PBS y se recogieron en FORNACE con $10 \mathrm{mM}$ EDTA, $50 \mathrm{mg} / \mathrm{ml}$ proteinasa $\mathrm{K}$ y 1\% SDS, procesándose para la obtención del DNA.

\section{III.1.b. Extracción del RNA.}

El RNA total se obtuvo de los cultivos celulares utilizando el reactivo TRIzol ${ }^{\circledR}$ LS (Invitrogen $\left.{ }^{\mathrm{TM}}\right)$.

\section{III.2. REACCIÓN EN CADENA DE LA POLIMERASA (PCR).}

Tanto para la amplificación de DNA genómico, como para la amplificación de CDNA, se utilizó el sistema de PCR Master Mix 2x (Promega). Los oligonucleótidos forward y reverse se añadieron a una concentración final 0,5 $\mu \mathrm{M}$ y utilizamos 100 ng de DNA molde. 


\section{III.2.a. PCR de Transcripción inversa (RT-PCR).}

Para la síntesis de cDNA se utilizó el kit ImProm-IITM Reverse Transcription System (Promega) siguiendo las especificaciones del fabricante. Utilizamos Oligo $d T$, oligonucleótido que anilla en la cola poliA de los RNAs mensajeros.

Los tránscritos derivados de la $\beta 1$ y $\beta 2$-quimerina fueron amplificados por PCR anidada utilizando los oligonucleótidos y las condiciones de PCR descritos en la tabla 1.

Para comprobar que la síntesis de cDNA se había realizado con éxito, se amplificó por PCR el producto del gen de la GAPDH, gen que se expresa constitutivamente en todos los tejidos (Tabla 3).

Tabla 3: Secuencia de oligonucleótidos utilizados en la amplificación de los tránscritos del gen de la GAPDH.

\begin{tabular}{|c|c|c|}
\hline Oligonucleótidos & Secuencia & Condiciones PCR \\
\hline GAPDH-F & 5'- CCA CCC ATG GCA AAT TCC ATG GCA -3' & \multirow{2}{*}{$\begin{array}{l}55^{\circ} \mathrm{C} \text { anillamiento } \\
30 \text { ciclos } \\
30^{\prime \prime} \text { extensión }\end{array}$} \\
\hline GAPDH-R & $5^{\prime}-$ TCT AGA CGG CAG GTC AGG TCC ACC - $3^{\prime}$ & \\
\hline
\end{tabular}

\section{ANÁLISIS MUTACIONAL DEL GEN CHN2.}

\section{IV.1. SELECCIÓN DE LOS CASOS A ESTUDIO.}

Para la búsqueda de mutaciones en el gen CHN2 se utilizaron muestras de DNA procedentes de sangre periférica de 23 pacientes con síndrome mielodisplásico (SMD) facilitadas por el Servicio de Hematología del Hospital Clínico de Salamanca, bajo consentimiento informado de los pacientes y cumpliendo las normas legales para Estudios Clínicos en España y las del Comité de Ética del Hospital Universitario de Salamanca. Del mismo modo utilizamos DNA extraído de 25 muestras de tumor de pacientes diagnosticados con glioblastoma multiforme en el Servicio de Neurocirugía del Hospital Clínico de Salamanca y 90 muestras de DNA de tumores esporádicos de mama procedentes del Servicio de Oncología del Hospital Clínico de Salamanca.

\section{IV.2. AMPLIFICACIÓN DEL GEN CHN2 POR PCR.}


El gen CHN2 contiene 13 exones. Se amplificaron todos los exones codificantes del gen $C H N 2$, junto a zonas intrónicas flanqueantes a estos exones. Estos fragmentos se amplificaron por PCR convencional utilizando los oligonucleótidos y las condiciones de PCR descritas en la tabla 4.

Tabla 4: Oligonucleótidos y condiciones de PCR utilizados en la amplificación de los exones y de las secuencias intrónicas flanqueantes del gen CHN2. (F:Forward; R: Reverse).

\begin{tabular}{|c|c|c|c|}
\hline Oligonucleótido & Secuencia & $\begin{array}{l}\text { Producto } \\
\text { de la PCR }\end{array}$ & Condiciones PCR \\
\hline Chim ex1-F & 5'- ATC TGG TGG AGC AGG AAG TGC A -3' & \multirow{2}{*}{$\begin{array}{l}326 \mathrm{pb} \\
\text { Exón } 1\end{array}$} & \multirow{2}{*}{$\begin{array}{l}55^{\circ} \mathrm{C} \text { anillamiento } \\
35 \text { ciclos } 1 \text { ' extensión }\end{array}$} \\
\hline Chim ex1-R & $5^{\prime}$ - AGC GGG CGG GAT GGC CAC AGG TA - 3' & & \\
\hline Chim ex2-F & 5' - GGA CAG ACT GTT GTT CCT CCA G - 3' & \multirow{2}{*}{$\begin{array}{l}218 \mathrm{pb} \\
\text { Exón } 2\end{array}$} & $55^{\circ} \mathrm{C}$ anillamiento \\
\hline Chim ex2-R & $5^{\prime}$ - CTT GTG TGC ACA TCG CTG GCA - 3' & & 35 ciclos 1' extensión \\
\hline Chim ex3-F & 5' - TGA GAT GTA CTT AGG TGG AAA T - 3' & \multirow{2}{*}{$\begin{array}{l}229 \mathrm{pb} \\
\text { Exón } 3\end{array}$} & $55^{\circ} \mathrm{C}$ anillamiento \\
\hline Chim ex3-R & 5' - TCC CTC CAC TCT CTA CAT AGT GCT - 3' & & 35 ciclos 1' extensión \\
\hline Chim ex4-F & 5' - ATT ACT ACC AGG ACC CTA GTT C - 3' & \multirow{2}{*}{$\begin{array}{l}241 \mathrm{pb} \\
\text { Exón } 4\end{array}$} & $55^{\circ} \mathrm{C}$ anillamiento \\
\hline Chim ex4-R & $5^{\prime}$ - CAA TAG ACA TAT GAT GAT GAC - 3' & & 35 ciclos $1^{\prime}$ extens \\
\hline Chim ex5-F & 5' - TGT GGT CCT TAT TCT GTA TGT GGT - 3' & \multirow{2}{*}{$\begin{array}{l}266 \mathrm{pb} \\
\text { Exón } 5\end{array}$} & $55^{\circ} \mathrm{C}$ anillamiento \\
\hline Chim ex5-R & 5' - TGT TAT GTA TAC TCT GCT ACA AT - 3' & & 35 ciclos 1 ' extensión \\
\hline Chim ex6-F & 5' - TAT CAT TCC ACA CTG TGC TTA T - 3' & \multirow{2}{*}{$\begin{array}{l}433 \mathrm{pb} \\
\text { Exón } 6\end{array}$} & $55^{\circ} \mathrm{C}$ anillamiento \\
\hline Chim ex6-R & 5' - TCA GCA AAT CGC ACC TAT AGT - 3' & & 35 ciclos 1 'extensión \\
\hline Chim ex7-F & 5' - GGGT TCG AAA ATC CTG ACA GCA CAG - 3' & \multirow{2}{*}{$\begin{array}{l}413 \mathrm{pb} \\
\text { Exón } 7\end{array}$} & $60^{\circ} \mathrm{C}$ anillamiento \\
\hline Chim ex7-R & 5' - GAC TTT ACA GTC AGA AAC CAG ACG - 3' & & 35 ciclos 1' extensión \\
\hline Chim ex8-F & 5' - TCA TTG ACA TGT CTG AGG CTA CCT - 3' & \multirow{2}{*}{$\begin{array}{l}219 \mathrm{pb} \\
\text { Exón } 8\end{array}$} & $55^{\circ} \mathrm{C}$ anillamiento \\
\hline Chim ex8-R & 5' - TCC AGC TCA GCA CAG TGG CAT - 3' & & 35 ciclos 1' extensión \\
\hline Chim ex9-F & 5' - ACG GGA TAG ATG TTC CAG AGA - 3' & \multirow{2}{*}{$\begin{array}{l}385 \mathrm{pb} \\
\text { Exón } 9\end{array}$} & $55^{\circ} \mathrm{C}$ anillamiento \\
\hline Chim ex9-R & 5' - ACT CTG TTT СCT TGA CAA CTG TA - 3' & & 35 ciclos 1 ' extensión \\
\hline Chim ex10-F & 5' - TGT AGT ATA GAC GTG AAA TTA GT - 3' & \multirow{2}{*}{$\begin{array}{l}225 \mathrm{pb} \\
\text { Exón } 10\end{array}$} & $55^{\circ} \mathrm{C}$ anillamiento \\
\hline Chim ex10-R & 5' - TAC TTC CAA TCG AGA AGG GTG TT - 3' & & 35 ciclos 1' extensión \\
\hline Chim ex11-F & 5' - TCT GTA CAT GCC TTG GTG AAA T - 3' & \multirow{2}{*}{$\begin{array}{l}268 \text { pb } \\
\text { Exón } 11\end{array}$} & $60^{\circ} \mathrm{C}$ anillamiento \\
\hline Chim ex11-R & 5' - TAT CTG AAG GTC AAA AGC ACT - 3' & & 35 ciclos 1' extensión \\
\hline Chim ex12-F & 5' - CAT GAA TTT ATT AGA ATC CTT C - 3' & \multirow{2}{*}{$\begin{array}{l}282 \mathrm{pb} \\
\text { Exón } 12\end{array}$} & $55^{\circ} \mathrm{C}$ anillamiento \\
\hline Chim ex12-R & 5' - TCC TCA TGC ATT AAC CGC TCT - 3' & & 35 ciclos 1 ' extensión \\
\hline Chim ex13-F & $5^{\prime}$ - CTT ACA TAC ATA ATC AAT AC - 3' & \multirow{2}{*}{$\begin{array}{l}293 \mathrm{pb} \\
\text { Exón } 13\end{array}$} & $63^{\circ} \mathrm{C}$ anillamiento \\
\hline Chim ex13-R & 5' - CAA CTT GGA TGG TGC TGG GGC - 3' & & 35 ciclos 1 ' extensión \\
\hline
\end{tabular}

\section{IV.3. DETECCIÓN DE MUTACIONES MEDIANTE CSGE.}

Los fragmentos amplificados fueron sometidos a análisis CSGE (Conformation Sensitive Gel Electrophoresis) siguiendo la técnica descrita por Orita ${ }^{160}$, con algunas modificaciones. Los productos de PCR se desnaturalizan a $95{ }^{\circ} \mathrm{C}$ y se renaturalizan 
disminuyendo la temperatura $1^{\circ} \mathrm{C}$ por minuto, para permitir la formación de heterodúplex en el caso de individuos heterocigotos (apareamiento entre cadenas complementarias que difieren en una porción muy pequeña de su secuencia) (Fig. 16). Tras ese proceso, las muestras se sometieron a una electroforesis en geles de acrilamida parcialmente desnaturalizantes. Los homodúplex y heterodúplex se visualizaron mediante tinción de plata de los geles utilizando el kit DNA Silver Staining (Amershan). Las PCRs que presentaron un patrón de migración diferencial entre los distintos pacientes se secuenciaron utilizando los oligonucleótidos descritos en la tabla 4.

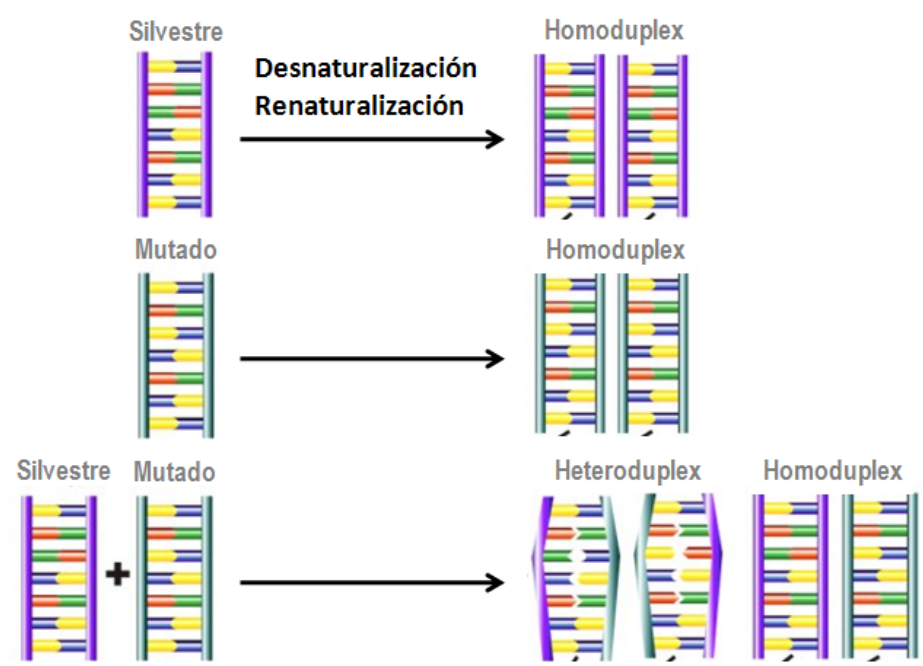

Figura 16: Esquema de la formación de Heterodúplex tras la desnaturalización y posterior renaturalización del producto de PCR. Las hebras madre, tras la desnaturalización, pueden renaturalizarse con su hebra complementaria correspondiente, o con la hebra complementaria del otro alelo. Si existe un cambio de nucleótido en heterocigosis dentro del fragmento amplificado, la renaturalización puede generar Heteroduplex, es decir apareamiento entre dos hebras que son complementarias en todos los nucleótidos excepto uno, generando un desapareamiento en este punto, lo que genera un cambio en la conformación del DNA, detectable por CSGE.

\section{ESTUDIOS POBLACIONALES DE POLIMORFISMOS DEL GEN CHN2.}

\section{V.1. POBLACIÓN ESTUDIADA.}

Se realizaron estudios poblacionales en tres grupos de poblaciones: pacientes con cáncer, pacientes fumadores y pacientes alcohólicos; y se compararon son las poblaciones control correspondientes: población sin cáncer, población no fumadora, 
población no consumidora de alcohol. Las muestras de sangre periférica para estos estudios fueron obtenidas previo consentimiento informado, siguiendo las normas legales para Estudios Clínicos de España y las del Comité de Ética del Hospital Universitario de Salamanca. Se recopiló la información relevante para el estudio (edad, sexo, antecedentes familiares) protegiendo siempre la privacidad y el anonimato de cada individuo.

\section{V.1.a. Estudios poblacionales en cáncer.}

Se seleccionaron tres grupos de pacientes con cáncer para los estudios poblacionales (Tabla 5). Se estudiaron 23 individuos con Síndrome Mielodisplásico (SMD), 144 muestras de sangre periférica de individuos diagnosticados de tumores del Sistema Nervioso Central (SNC) que se dividieron en tres grupos: meningiomas, astrocitomas anaplásicos y glioblastomas multiformes; y 214 muestras de sangre periférica de mujeres diagnosticadas de cáncer de mama esporádico.

Como grupo control se estudiaron 218 individuos con edad superior a 50 años que no presentaran historia personal ni familiar de cáncer de ningún tipo.

Tabla 5: Tabla resumen de las características de los grupos de cáncer y el grupo control. Datos de la edad y de la distribución por sexos de los grupos. Se indica la media de edad y desviación estándar.

\begin{tabular}{|l|c|c|c|c|}
\multirow{2}{*}{\multicolumn{1}{c|}{ Casos }} & \multicolumn{2}{c|}{ Edad } & \multicolumn{2}{c|}{ Sexo } \\
\cline { 2 - 5 } \multicolumn{1}{c|}{ Síndrome mielodisplásico } & - & Mediana & Mujeres & Hombres \\
\hline Tumores SNC & $60,8 \pm 13,4$ & 63 & $75(52,8 \%)$ & $67(47,2 \%)$ \\
\hline -Astrocitomas & $55,5 \pm 12,4$ & 55 & $9(40,9 \%)$ & $13(59,1 \%)$ \\
\hline -Meningiomas & $62,1 \pm 14,4$ & 64,5 & $54(72 \%)$ & $21(28 \%)$ \\
\hline -Glioblastomas & $61,3 \pm 11,9$ & 64 & 12 & 33 \\
\hline Cáncer de mama & $56,1 \pm 13,2$ & 57 & $213(100 \%)$ & $0(0 \%)$ \\
\hline Controles & $>50$ & & $153(70,1 \%)$ & $65(29,8 \%)$ \\
\hline
\end{tabular}

\section{V.1.b. Estudios poblacionales en drogodependencias (tabaquismo y alcoholismo).}

Se estudiaron 188 individuos fumadores seleccionados en el Servicio de Neumología del Hospital Universitario de Salamanca (Tabla 6). Se consideró fumador, según criterio de la OMS (ㅇganización Mundial de la Salud), a aquellos individuos que 
fumaban diariamente durante al menos un mes antes de la extracción de la muestra. Se recogieron datos de la cantidad de cigarrillos que fuman al día. Debido a las condiciones socioculturales, los fumadores mayores de 65 años recopilados fueron exclusivamente varones.

Como grupo control se estudiaron 198 individuos que no hubieran fumado de manera regular y no padecían ninguna enfermedad grave relevante ni presentaban adicción a ninguna otra sustancia (drogas, alcohol).

Tabla 6: Distribución de los fumadores y los controles utilizados en este estudio, por edad, sexo y número de cigarrillos fumados al día. Los casos se agruparon, a su vez, según la edad: mayores y menores de 65 años; y según el número de cigarrillos fumados al día: hasta 20 cigarrillos o más de 20. Las medias de edad y el número de cigarrillos vienen acompañadas de la desviación estándar correspondiente.

\begin{tabular}{|l|c|c|c|c|c|c|}
\multirow{2}{*}{\multicolumn{1}{c|}{ Casos }} & \multicolumn{2}{c|}{ Edad } & \multicolumn{2}{c|}{ Sexo } & \multicolumn{2}{c}{ Cigarrillos } \\
\cline { 2 - 7 } & Media & Mediana & Mujeres & Hombres & Media & Mediana \\
\hline Fumadores & $59,5 \pm 18,8$ & 66 & $54(28,72 \%)$ & $134(71,28 \%)$ & $26,3 \pm 11,1$ & 20 \\
\hline $\mathbf{6 5}$ años & $76 \pm 6,5$ & 76 & $0(0 \%)$ & $95(100 \%)$ & $27,2 \pm 10,7$ & 20 \\
\hline $\mathbf{6 5}$ años & $42 \pm 9,5$ & 40 & $54(58,06 \%)$ & $39(41,94 \%)$ & $25,2 \pm 11,4$ & 20 \\
\hline $\mathbf{2 0}$ cigarrillos/día & $60,2 \pm 17,7$ & 67 & $15(21,13 \%)$ & $56(78,87 \%)$ & $37 \pm 9,3$ & 40 \\
\hline$>\mathbf{2 0}$ cigarrillos/día & $60,2 \pm 19,6$ & 67 & $36(34,95 \%)$ & $67(65,05 \%)$ & $18,8 \pm 3,5$ & 20 \\
\hline Controles & $46 \pm 18,8$ & 42 & $51(25,76 \%)$ & $147(74,24 \%)$ & - & - \\
\hline
\end{tabular}

Así mismo se estudiaron 279 individuos alcohólicos seleccionados en la Unidad de Alcoholismo del Servicio de Medicina Interna del Hospital Universitario de Salamanca (Tabla 7). Se consideraron como individuos alcohólicos pacientes que consumían más de $120 \mathrm{~g}$ de etanol al día, con un consumo continuado de al menos los 10 años anteriores a la extracción de la muestra. Dentro de los alcohólicos, se agruparon en abusadores y dependientes del alcohol siguiendo los criterios DSM-IV expuestos por la Asociación Americana de Psiquiatría (APA). Debido a las características socioculturales de la población estudiada, la mayoría de los alcohólicos que llegan a las consultas médicas son varones, por lo que la población seleccionada tanto para el grupo de casos como el de controles es masculina, a fin de no cometer un error de sesgo por sexo. Se utilizaron como controles 143 varones sanos, sin antecedentes de alcoholismo ni personales ni familiares, y con un consumo de alcohol diario inferior a los 10 gramos. 
Tabla 7: Distribución de los alcohólicos y los controles utilizados en este estudio, por edad, sexo y, en el caso de los fumadores, siguiendo los criterios DSM-IV de la Asociación Americana de Psiquiatría, según sean abusadores o dependientes del alcohol. La media de edad viene acompañada de la desviación estándar correspondiente.

\begin{tabular}{|l|c|c|c|c|}
\multirow{2}{*}{\multicolumn{1}{c|}{ Casos }} & \multicolumn{2}{c|}{ Edad } & \multicolumn{2}{c}{ Sexo } \\
\cline { 2 - 5 } & Media & Mediana & Mujeres & Hombres \\
\hline Alcohólicos & $51,99 \pm 12,4$ & 52 & $0(0 \%)$ & $279(100 \%)$ \\
\hline -Abusadores & $58,50 \pm 11,622$ & 59 & $0(0 \%)$ & $101(100 \%)$ \\
\hline -Dependientes & $48,29 \pm 11,474$ & 48 & $0(0 \%)$ & $178(100 \%)$ \\
\hline Controles & $46,13 \pm 19,714$ & 40 & $0(0 \%)$ & $143(100 \%)$ \\
\hline
\end{tabular}

\section{V.2. GENOTIPADO DE LOS POLIMORFISMOS DEL GEN CHN2.}

\section{V.2.a. Análisis de los polimorfismos por longitud de los fragmentos de restricción (RFLP).}

El polimorfismo IVS5+7C>T se estudió mediante digestión del producto de PCR del exón 5 (265 pb) con la enzima de restricción Hhal (Fermentas). Esta enzima reconoce la secuencia GCGC, presente en el alelo $\mathrm{T}$ y ausente en el alelo $\mathrm{C}$. En el caso del genotipo $\mathrm{TT}$, la digestión con Hhal genera dos fragmentos de 177 y 89 pb y en el del genotipo CC, se genera un fragmento único de $265 \mathrm{pb}$. En el caso de un heterocigoto para el polimorfismo (CT), se obtendrán los 3 fragmentos (Fig. 17A).

El polimorfismo c.366A>G (p.S122S), localizado en el exón 6, se estudió mediante digestión del producto de PCR (431pb) con la enzima de restricción Taql (Fermentas) que reconoce la secuencia TCGA presente en el alelo A y ausente en el alelo G. En el caso del genotipo AA, la enzima cortaría en ambos alelos, produciendo dos fragmentos de restricción de 135 y 298 pb, mientras que en el genotipo GG, la enzima no cortaría, manteniéndose el fragmento íntegro de 431 pb. En el caso del genotipo heterocigoto para el polimorfismo (GA), se obtendrían los tres fragmentos (Fig. 17B).

A

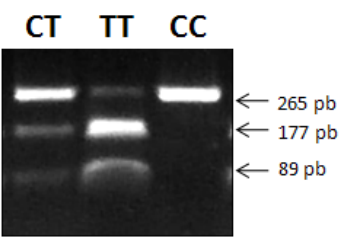

B

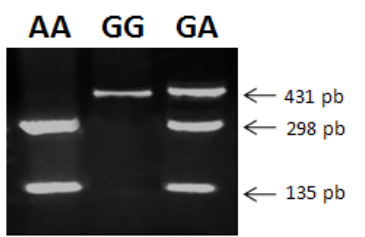

Figura 17: Análisis de los polimorfismos IVS5+7C>T y c.366A>G (p.S122S) por longitud de los fragmentos de restricción. (A) Electroforesis de la digestión con enzima Hhal de PCRs del exón 5 del gen CHN2. (B). Electroforesis de la digestión con la enzima de restricción Taql de PCRs del exón 6 del CHN2. 


\section{V.2.b. Discriminación alélica por sondas TaqMan.}

En la discriminación alélica por sondas TaqMan, la amplificación y la detección del genotipo ocurren simultáneamente. Se utilizaron sondas TaqMan (Applied Biosystem) diseñadas específicamente para cada alelo, que difieren en un único nucleótido de su secuencia y en el fluorocromo con el que están marcadas (VIC o FAM). Dependiendo del genotipo de la muestra, una de las dos sondas o ambas se hibridan al producto de PCR en proceso de amplificación.

Para el análisis del polimorfismo IVS5+7C >T se utilizó la sonda C_32158300 y para estudiar el polimorfismo c.611A>G (p.H203R) se utilizó la sonda C_22274692 (Applied Biosystem) (Fig. 18). La reacción de genotipado se llevó a cabo en un volumen final de 10 $\mu \mathrm{L}$, utilizando TaqMan Genotyping Master Mix 2x (Applied Biosystem). En todos los casos se utilizó un equipo StepOne Plus (Applied Biosystem) bajo las condiciones recomendadas por el fabricante para este tipo de estudios.

A

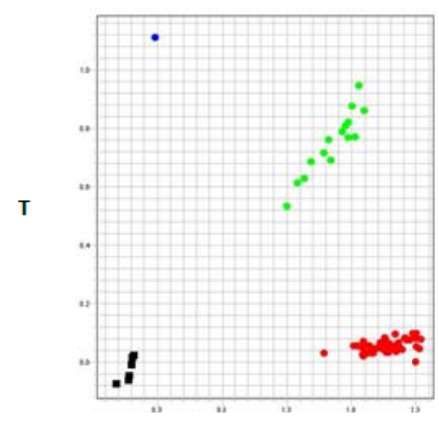

C
B

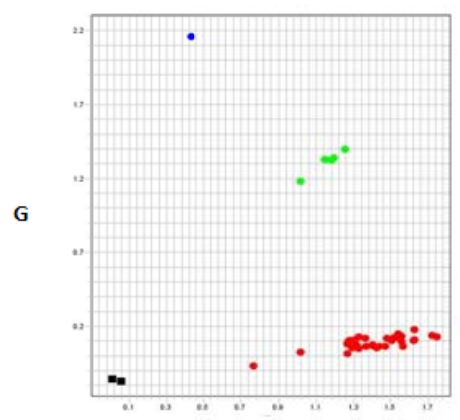

A

Figura 18: Discriminación alélica por sondas TaqMan ${ }^{\circledR}$ de los polimorfismos c.366G>A (p.S122S) y c.611A>G (p.H203R). (A) Diagrama de la fluorescencia emitida por las sondas TaqMan en los estudios de discriminación alélica del polimorfismo c.366G>A (p.S122S). (Puntos Azules: Homocigoto TT; Verdes: Heterocigotos CT; Rojos: Homocigotos CC). (B) Diagrama de los resultados de discriminación alélica del polimorfismo c.611A>G (p.H203R). (Puntos Azules: Homocigotos GG; Verdes: Heterocigotos AG; Rojos: Homocigotos AA).

\section{V.2.c. Discriminación alélica mediante cromatografía líquida de alto rendimiento}

\section{desnaturalizante (dHPLC).}

El polimorfismo c.611A>G (p.H203R) se estudió mediante discriminación alélica, utilizando el sistema WAVE $^{\circledR}$ (Transgenomic, Gran Bretaña), basado en la cromatografía 
líquida de intercambio iónico en fase reversa ${ }^{161}$ acoplado al software de análisis (Navigator, Sistema WAVE, Transgenomic). Para ello, se amplificó el exón 7 del gen CHN2 y los productos de PCR fueron desnaturalizados y renaturalizados para permitir la formación de heterodúplex. Se inyectaron estas muestras una primera vez en la columna de AHPLC, a una temperatura de desnaturalización ajustada de $59,2^{\circ}$ C. La elución se realizó con acetato de trietilamonio (TEAA) y concentraciones crecientes de acetonitrilo. Los heterodúplex se eluyen antes que los homodúplex puesto que tienen una unión más débil a la matriz, debido a su configuración más abierta causada por el desapareamiento de bases.

Aunque este sistema puede discriminar en la mayoría de los casos, no sólo entre homocigotos de heterocigotos, sino también entre homocigotos, no ocurre así en nuestro ensayo. Por ello, para poder discriminar entre homocigotos AA y homocigotos GG, tuvimos que generar heterocigotos artificiales. Se utilizó el producto de PCR de un control homocigoto AA cuya secuencia completa se conocía por secuenciación automática, y se mezcló en una proporción 1:1 con aquellas muestras identificadas como homocigotas tras la primera separación por dHPLC. Posteriormente, estas mezclas fueron desnaturalizadas y renaturalizadas, e inyectadas de nuevo en el dHPLC. En este caso, aquellas muestras que aparecieran como homocigotos corresponderían a homocigotos AA, y las heterocigotas artificiales en realidad corresponderían a homocigotos GG (Fig. 19).

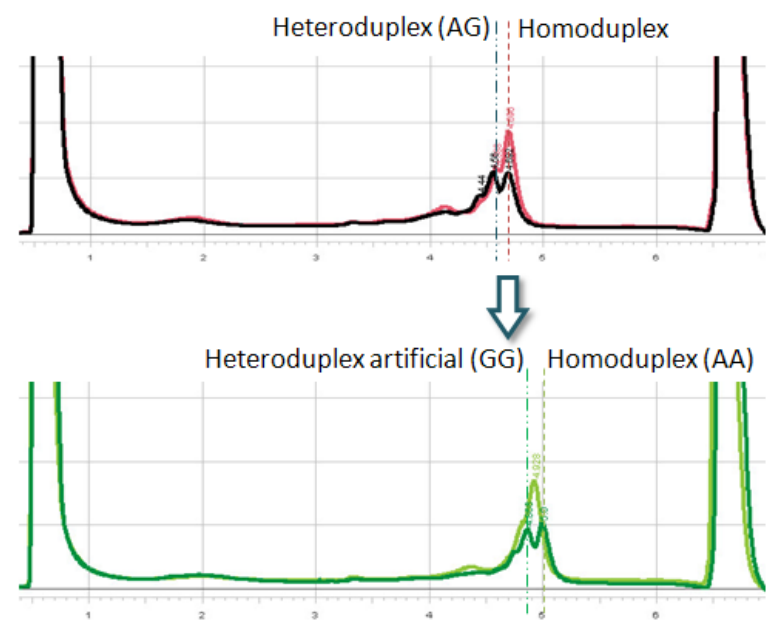

Figura 19: Genotipado del polimorfismo c.611A>G (p.H203R). Discriminación alélica mediante dHPLC. En el panel superior, gráfico con patrones diferenciales de una muestra homocigota (1 pico) y una heterocigota AG (2 picos). En el panel inferior, gráfico con patrones diferenciales de homocigoto AA (1 pico) y homocigoto GG (2 picos) tras la mezcla de las muestras con una muestra homocigota AA control positivo. 


\section{V.2.d. Análisis estadístico en los estudios de asociación.}

Se comprobó, mediante el test de Chi-cuadrado de Pearson, que los grupos de pacientes y controles cumplían el equilibrio Hardy-Weinberg (HWE), es decir, que presentan una distribución poblacional propia de una población panmíctica.

El análisis estadístico de la distribución de frecuencias genotípicas y de agrupación de genotipos de los polimorfismos estudiados del gen CHN2 se llevó a cabo mediante el empleo de tablas de contingencia y el test de Chi-cuadrado de Pearson en el programa SPSS 15.0. Cuando la frecuencia genotípica del genotipo menos frecuente fue inferior al 5\%, se reagrupan los datos en agrupaciones genotípicas. Si tras la agrupación la frecuencia sigue siendo inferior al $5 \%$, el análisis estadístico se realiza con el test de Fischer. Se consideraron resultados estadísticamente significativos aquellos para los que la probabilidad era menor del $5 \%(p<0.05)$. Cuando el valor de $p$ fue significativo, se halló el valor Odss ratio, que expresa la probabilidad de que un suceso ocurra frente a que no ocurra, en nuestro caso, la probabilidad de que un individuo que porte un genotipo asociado con una enfermedad, sufra esa enfermedad, frente a un individuo no portador.

\section{Transfecciones transitorias y estimulación celular.}

Para los experimentos de inmunofluorescencia y los ensayos de pull-down transfectamos células COS-1 con el reactivo FuGene ${ }^{\circledR} 6$ (Roche) siguiendo las instrucciones proporcionadas por el fabricante. Se utilizó una proporción FuGene/plásmido de 3:1. En los casos indicados, 48h después de la transfección las células se privaron de suero durante 12 horas y posteriormente se estimularon con $3 \mu \mathrm{M}$ PMA (Forbol 12-miristato 13-acetato) (Sigma) durante 15 minutos.

\section{Microscopía confocal e inmunofluorescencia indirecta.}

Utilizamos la línea celular COS-1 que se había crecido sobre cubreobjetos circulares de $12 \mathrm{~mm}$ de diámetro. Cuando estas células alcanzaron una confluencia adecuada (50\%), fueron transfectadas de manera transitoria con las construcciones correspondientes en los vectores pEGFP o pCEFL-FLAG. 48 horas después de la transfección las células se sometieron a los tratamientos en los casos indicados, se 
lavaron con PBS y se fijaron con formaldehido al 3,7\% en PBS durante 15 min. A continuación, se permeabilizaron con Tritón X-100 (Boehringer Mannheim) al 0,5\% en PBS durante 10 min y se lavaron con PBS. La detección de las proteínas etiquetadas con el epítopo FLAG se realizó mediante incubación con el anticuerpo primario anti-FLAG M2 Monoclonal (Sigma) (1:1000) en PBS con BSA (1mg/ml). El anticuerpo secundario utilizado fue anti-Mouse IgG Alexa Fluor 488 (Alexa) a una concentración de 1:400 en el mismo tampón. Las proteínas etiquetadas con EGFP se visualizaron directamente en el microscopio. Para teñir los núcleos de las células, se incubaron los cristales con una dilución 1/10000 de DAPI (diclorhidrato de 4',6-diamidino-2-fenilindol) (Roche). Finalmente, las preparaciones fueron montadas sobre portaobjetos utilizando el reactivo Mowiol (Calbiochem).

Las células fueron analizadas mediante microscopía confocal, utilizando un microscopio LEICA SP5 modelo DMI-6000B acoplado a un software informático LEICA LAS AF.

\section{Electroforesis de proteínas y Western Blot.}

Los extractos proteicos se hirvieron en tampón de muestra de Laemmli (SPLB) durante $10 \mathrm{~min}$, y a continuación se resolvieron en geles de poliacrilamida al $12 \%$ utilizando tampón de carrera conteniendo 0,25M Tris, $2 \mathrm{M}$ glicina y 0,5\% SDS. Como marcador de peso molecular se utilizó PageRuler ${ }^{\text {TM }}$ Prestainer protein ladder plus (Fermentas). A continuación, las proteínas fueron transferidas a membranas de PVDF Amersham Hybond ${ }^{T M}$ utilizando un tampón de transferencia compuesto por $25 \mathrm{mM}$ Tris, 192 mM glicina y $20 \%$ metanol. Para verificar la eficiencia de la transferencia, las membranas fueron teñidas de manera reversible con solución Ponceau S (Sigma).

Para la inmunodetección, en primer lugar incubamos las membranas con $25 \mathrm{mM}$ Tris-HCl pH 8, conteniendo 0,1\% de Tween-20 (Sigma) (TBS-T) y 5\% de leche desnatada. Las membranas se mantuvieron en esta solución $1 \mathrm{~h}$ a temperatura ambiente 0 , alternativamente, durante toda la noche a $4^{\circ} \mathrm{C}$. La hibridación con los anticuerpos primarios se llevó a cabo durante $1 \mathrm{~h}$ a temperatura ambiente o a $4^{\circ} \mathrm{C}$ toda la noche. Los anticuerpos primarios utilizados se describen la tabla 8. Posteriormente, las membranas se incubaron durante $1 \mathrm{~h}$ a temperatura ambiente con una dilución 1:3000 de los 
anticuerpos secundarios de la especificidad adecuada conjugados a peroxidasa (HRP) (Amersham Biosciences). Después de cada incubación, las membranas se lavaron 3 veces en TBS-T durante $10 \mathrm{~min}$. La detección de las proteínas se realizó mediante quimioluminiscencia utilizando el reactivo Pierce $^{\circledR}$ ECL Western Blotting Substrate (Thermo Scientific).

Tabla 9: Relación de anticuerpos para western blot utilizados en este trabajo.

\begin{tabular}{|l|l|l|l|l|}
\multicolumn{2}{|c|}{ Anticuerpo } & \multicolumn{1}{|c|}{ Origen } & \multicolumn{1}{c|}{ Compañía } & \multicolumn{1}{c|}{ Dilución } \\
\hline \multirow{3}{*}{ Primarios } & $\begin{array}{l}\text { Anti-FLAG } \\
\text { Monoclonal }\end{array}$ & Ratón & Sigma & $1: 1000$ \\
\cline { 2 - 5 } & $\begin{array}{l}\text { Anti-GFP } \\
\text { Monoclonal }\end{array}$ & Ratón & Covance & $1: 3000$ \\
\cline { 2 - 5 } & $\begin{array}{l}\text { Anti-Rac } \\
\text { Monoclonal }\end{array}$ & Ratón & $\begin{array}{l}\text { BD Transduction } \\
\text { Laboratories }\end{array}$ & $1: 1000$ \\
\hline Secundario & $\begin{array}{l}\text { Anti-mouse IgG } \\
\text { HRP }\end{array}$ & Cabra & $\begin{array}{l}\text { Amersham GE } \\
\text { Healthcare }\end{array}$ & $1: 3000$ \\
\hline
\end{tabular}

\section{Purificación del dominio RBD.}

Se utilizaron cultivos en LB-ampicilina de bacterias BL-21 transformadas con el plásmido de expresión del dominio de unión a Rac de PAK (pGEX-PAK-RBD) fusionado a GST. Los cultivos se incubaron hasta alcanzar una $\mathrm{DO}_{600}$ de $0,4-0,7$. En ese momento, se indujo la expresión de la proteína de fusión mediante la adición al cultivo de IPTG 0,5 $\mathrm{mM}$. Transcurridas $3-4 \mathrm{~h}$ a $37^{\circ} \mathrm{C}$, las células fueron recogidas mediante centrifugación, resuspendidas en PBS frío con inhibidores de proteasas (Complete de Roche) y lisadas por sonicación. A continuación, se añadió Tritón X-100 a una concentración final del 1\%, incubándose la mezcla en hielo durante $30 \mathrm{~min}$. Tras centrifugar el lisado, se recogió el sobrenadante que se incubó con Glutation-sepharose $4 B$ (GE Healthcare) durante $2 \mathrm{~h}$ a $4^{\circ}$ C. La proteína GST-PAK fue recuperada de la matriz por incubación con una solución de glutatión (10 mM glutatión; 50 mM Tris- $\mathrm{HCl}$ pH 8). Finalmente, se eliminó el glutatión de la muestra utilizando columnas PD-10 Desalting column (GE Healthcare). Calculamos la concentración de proteína mediante espectrofotometría utilizando el reactivo Bio-Rad Protein Assay (Bio-Rad) y mediante electroforesis en un gel de poliacrilamida al $10 \%$, utilizando como estándares cantidades crecientes de BSA. Los geles se tiñeron con una solución de azul de Coomassie al 0,5\% y se lavaron con solución de desteñido (10\% ácido 
acético, 50\% metanol) para visualizar las proteínas. La proteína purificada se almacenó en una solución de glicerol al $50 \%$ en PBS a $-80^{\circ} \mathrm{C}$ hasta su utilización.

\section{Determinación de la actividad de Rac: Ensayo de Pull-down.}

Transfectamos células COS-1 con las diferentes construcciones de las isoformas de quimerinas fusionadas con GFP. Tras 24-48 horas, las células se lisaron con tampón de lisis $(20 \mathrm{mM}$ Tris- $\mathrm{HCl} \mathrm{pH}$ 7.4, $150 \mathrm{mM} \mathrm{NaCl}, 5 \mathrm{mM} \mathrm{MgCl} 2,0.5 \% \mathrm{NP} 40,5 \mathrm{mM} \beta-$ glicerofosfato, $1 \mathrm{mM}$ DTT, inhibidores de proteasas (Complete de Roche)), en el que se añadió la proteína GST-PAK-RBD (10 $\mu \mathrm{g} /$ muestra). Los lisados se incubaron durante 10 min en hielo y, a continuación, se centrifugaron a $13.000 \times g$ durante $10 \mathrm{~min}$ a $4{ }^{\circ} \mathrm{C}$. Una alícuota del sobrenadante se utilizó para analizar la expresión de las proteínas en los lisados totales. El resto del sobrenadante se incubó con la matriz de Glutation-sepharose $4 B$ (GE Healthcare) durante $1-2 \mathrm{~h}$ a $4^{\circ} \mathrm{C}$. La matriz se sedimentó por centrifugación $4^{\circ} \mathrm{C}$, se lavó tres veces con tampón de lisis y se hirvió en tampón SPLB. Las proteínas fueron analizadas mediante electroforesis en un gel de poliacrilamida al $12 \%$, seguida de Western blot. Las membranas se incubaron primero con anticuerpos anti-Rac para detectar los niveles de Rac total y de Rac-GTP. Posteriormente se incubaron con anticuerpo anti-GFP para comprobar los niveles de expresión de las proteínas resultantes de la transfección. En todos los casos, utilizamos un anticuerpo secundario anti-Mouse fusionado a la enzima HRP. Las membranas se incubaron y revelaron como se indica en el apartado de material y métodos específico de Western blot.

\section{PCR cuantitativa.}

Utilizamos PCR cuantitativa para conocer la expresión diferencial de las formas completas de la $\beta$-quimerina ( $\beta 1$-quimerina y $\beta 2$-quimerina) y de dos tipos diferentes de las variantes generadas por splicing alternativo: la isoforma $\beta 2-\mathrm{CHNdel}$ ex4-6, carente de los exones 4 al 6 ; y las isoformas derivadas de la isoforma completa $\beta 1$-quimerina, que carecen de parte del exón 7. 


\section{XI.1. DISEÑO DE OLIGONUCLEÓTIDOS.}

Diseñamos unos oligonucleótidos específicos para PCR cuantitativa que cumplieran una serie de criterios muy estrictos:

- Amplificaran cDNA pero no DNA genómico.

- Amplificaran en las mismas condiciones de termociclación.

- El producto de la amplificación fuera menor de 300 pb.

- Fueran específicos entre las variantes que se pretendían discriminar.

Atendiendo a estos criterios se diseñaron 6 pares de oligonucleótidos específicos expuestos en la tabla 9.

Tabla 9: Oligonucleótidos utilizados para los experimentos de PCR cuantitativa. (F: Forward; R: Reverse).

\begin{tabular}{|c|c|}
\hline Oligonucleótidos & Secuencia \\
\hline GAPDH-F & 5' - TGC ACC ACC AAC TGC TTA G - 3' \\
\hline GAPDH-R & $5^{\prime}$ - GGA TGC AGG GAT GAT GTT C - 3' \\
\hline TBP-F & 5' - GAG CTG TGA TGT GAA GTT TCC - 3' \\
\hline TBP-R & 5' - TCT GGG TTT GAT CAT TCT GTA G - 3' \\
\hline B2-FL-F & 5' - GCA GGC GGA TGA GCT TCT T - 3' \\
\hline B2-FL-R & $5^{\prime}$ - CTC ACC CAC AAA GTG TTT CCC - 3' \\
\hline B2-d4-6-F & 5' - TCA TTT GTC CTC GGG AGA TCT CCT - 3' \\
\hline B2-d4-6-R & $5^{\prime}$ - TGG GAA CGT GCT TGG AAC ACT GT - 3' \\
\hline B1-FL-F & 5' - GTG AAG GTG GGT GTC AAA GGC G - 3' \\
\hline B1-d7p-F & $5^{\prime}$ - CTT CGG GGT GAA GGT CCA CAC - 3' \\
\hline
\end{tabular}

\section{XI.2. SELECCIÓN DE GENES REPORTEROS.}

En una selección de los diferentes tipos de muestras usadas en el estudio realizamos amplificaciones de una batería de genes típicamente utilizados como genes reporteros en PCR cuantitativa relativa (Tabla 10). Un gen reportero ideal es un gen de expresión constitutiva cuyos niveles de expresión se mantienen constantes entre muestras de un mismo tipo. Para amplificar los genes reporteros utilizamos los oligonucleótidos proporcionados por en el kit comercial Human Endogenous Control Gene Panel (Tataa Biocenter). 
Para la normalización de los datos y la selección de los genes reporteros, utilizamos el programa GeNorm incorporado al software del programa de tratamiento de datos de PCR cuantitativa GenEx (MultiD Analysis AB). El valor de M indica la variación de la expresión de los genes reporteros entre muestras (Tabla 10).

\section{Tabla 10: Valores de M para los 6 genes reporteros estudiados.}

\begin{tabular}{|l|l|}
\hline \multicolumn{1}{|c|}{ Gen reportero } & \multicolumn{1}{c|}{ Valor de M } \\
\hline PPIA & 1,7958 \\
\hline YWHAZ & 1,5339 \\
\hline RPLP & 1,3021 \\
\hline HPRT1 & 1,1494 \\
\hline GAPDH & $\mathbf{0 , 8 6 6 1}$ \\
\hline TBP & $\mathbf{0 , 8 6 6 1}$ \\
\hline
\end{tabular}

De los 6 genes estudiados, elegimos GAPDH y TBP porque su expresión era la que menos variaba entre nuestras muestras cuando partíamos de la misma cantidad de cDNA.

\section{XI.3. REACCIÓN DE PCR CUANTITATIVA.}

Utilizamos el kit ImProm-IITM Reverse Transcription System (Promega) siguiendo las especificaciones del fabricante. El cDNA se sintetizó utilizando random primers.

La reacción de qPCR se realizó en un volumen final de $20 \mu \mathrm{L}$, utilizando FastStart Universal SYBR Green Master $2 x$ (Rox) (Roche), 0,5 $\mu \mathrm{M}$ de cada oligonucleótido y $100 \mathrm{ng}$ de cDNA. Se hicieron réplicas por triplicado de cada muestra, siempre añadiendo un control negativo de la reacción. Las PCRs se realizaron en placas de 96 pocillos en un termociclador Step-One Plus (Applied Biosystem).

\begin{tabular}{|l|l|}
\hline \multicolumn{3}{|c|}{ Condiciones de la PCR cuantitativa } \\
$95{ }^{\circ} \mathrm{C}, 10 \mathrm{~min}$ & (x1 ciclo) \\
$95^{\circ} \mathrm{C}, 15 \mathrm{~s} ;$ & $60^{\circ} \mathrm{C}, 30 \mathrm{~s} \quad$ (x40 ciclos) \\
Curva de melting: Aumento de $0,3^{\circ} \mathrm{C}$ cada $15 \mathrm{seg}$ \\
\hline
\end{tabular}




\section{XI.4. CURVAS DE MELTING.}

Para asegurar que la amplificación era específica, al final de cada proceso de termociclado se realizó una curva de melting, consistente en una desnaturalización y una progresiva renaturalización del producto de PCR amplificado (Fig. 20). Si existieran varios productos de la amplificación, se desnaturalizarán a distintas temperaturas, dando distinta señal en el proceso de melting.

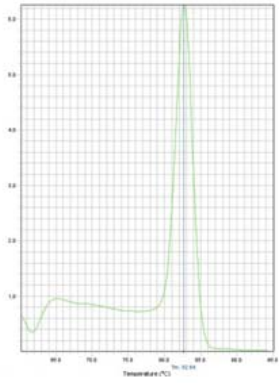

GAPDH

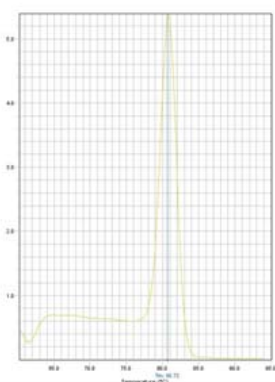

B2-CHN d4-6

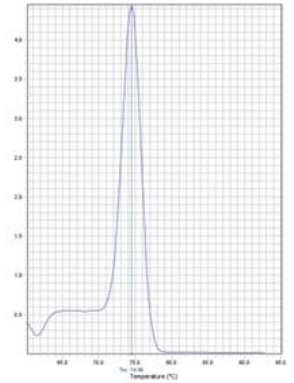

TBP

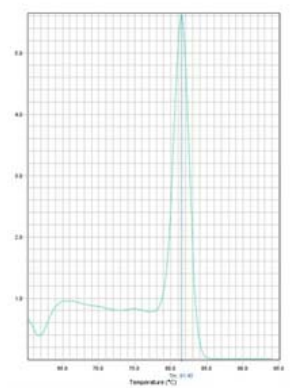

B1-quimerina completa

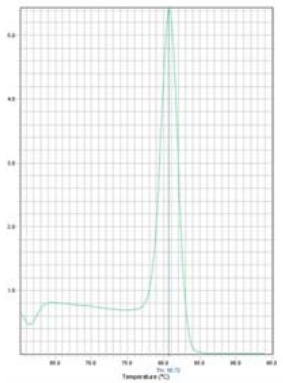

ß2-quimerina completa

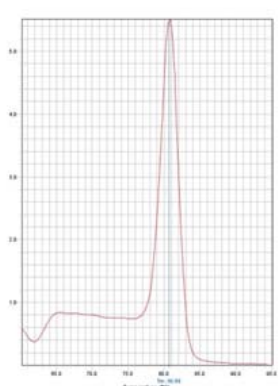

B1-CHN d7p

Figura 20: Representación de las curvas de melting para las PCRs de cuantitativa (Temperatura frente a $-R n$ ).

\section{XI.5. RECTAS PATRÓN.}

Para determinar la efectividad de la amplificación de las PCRs realizamos una recta patrón para cada amplificación, utilizando diluciones seriadas de un cDNA control (625, 250, 100, 40 y 10 ng por reacción). Estas pruebas nos permitieron establecer una recta patrón relativa que indica la eficiencia de la PCR de cada uno de los genes utilizados en el estudio (Tabla 11). Las diferencias en la eficiencia de las PCRs se calculan para poder corregir el error en la eficiencia de la expresión en los datos de Ct. 
La isoforma $\beta 1$-quimerina no se expresa o se expresa a muy bajo nivel en las muestras utilizadas en este trabajo, por ello no pudimos realizar una recta patrón a partir de diluciones seriadas de una muestra. Para asegurarnos que la falta de detección de esta isoforma se debía a una ausencia de expresión y no a una baja eficiencia de la PCR, realizamos una recta patrón utilizando diluciones seriadas de una construcción de la isoforma $\beta 1$-quimerina en un vector de expresión. La eficiencia de la PCR obtenida fue del 107,3\%, confirmando una buena PCR pero unos niveles de expresión de la muestra por debajo de lo discriminable por esta técnica para la isoforma $\beta 1$-quimerina.

Tabla 11: Datos de la recta patrón de la eficiencia de las PCRs utilizadas en la cuantificación relativa. La eficiencia de la PCR es el dato que se utiliza para la normalización.

\begin{tabular}{|l|l|l|l|l|l|l|}
\multicolumn{1}{l|}{ GAPDH } & TBP & $\begin{array}{l}\beta 2- \\
\text { Completa }\end{array}$ & $\begin{array}{l}\beta 2-\text { CHN } \\
\text { del ex4-6 }\end{array}$ & $\begin{array}{l}\beta 1- \\
\text { Completa }\end{array}$ & $\begin{array}{l}\beta 1-C H N \\
\text { del ex7p }\end{array}$ \\
\hline Pendiente & $-3,06$ & $-3,10$ & $-3,68$ & $-2,80$ & $-3,16$ & $-3,04$ \\
\hline Ordenada al origen & 27,18 & 34,51 & 36,98 & 35,82 & 8,86 & 35,57 \\
\hline Eficiencia de la PCR & $\mathbf{1 , 1 2 0}$ & $\mathbf{1 , 1 0 3}$ & $\mathbf{0 , 8 7 0}$ & $\mathbf{1 , 2 7 4}$ & $\mathbf{1 , 0 7 3}$ & $\mathbf{1 , 1 3 1}$ \\
\hline
\end{tabular}

\section{Estudios de metilación del promotor.}

\section{XII.1. ESTUDIOS BIOINFORMÁTICOS PREDICTIVOS DEL PROMOTOR.}

Analizamos la secuencia correspondiente a los promotores del gen CHN2 en varios programas informáticos: FirstEF ${ }^{162}$ (http://rulai.cshl.org/tools/FirstEF) que define inicios de la transcripción y la traducción, además de zonas reguladoras del promotor; CPG Island Searcher ${ }^{163}$ (http://www.uscnorris.com/cpgislands2) para búsqueda a gran escala de islas CpG; y Methyl Primer Express (Applied Biosystems), que además de caracterizar islas CpGs, permite el diseño de oligonucleótidos sobre el DNA bisulfitado.

\section{XII.2. MODIFICACIÓN DEL DNA POR BISULFITO.}

Se utilizó $1 \mu \mathrm{g}$ de DNA genómico en un volumen final de $50 \mu \mathrm{L}$, incluyendo un control negativo, para el proceso de modificación por bisulfito. Se añadieron $5,7 \mu \mathrm{L}$ de $\mathrm{NaOH} 3 \mathrm{M}$ incubando la muestra $10-15$ min a $37^{\circ} \mathrm{C}$, lo que permitió la desnaturalización química de las dobles cadenas del DNA. Tras esta incubación se añadió $33 \mu \mathrm{L}$ de 
hidroquinona $20 \mathrm{mM}$ (Sigma) y a continuación $530 \mu \mathrm{L}$ de Bisulfito Sódico $4 \mathrm{M} \mathrm{pH} 5.0$ (Sigma). La mezcla se incubó a $50^{\circ} \mathrm{C}$ durante 16-17 horas en oscuridad. La muestra se purificó con el Kit Wizard DNA clean-up system (Promega) siguiendo las instrucciones del fabricante. Posteriormente se desnaturalizó de nuevo el DNA purificado, añadiendo 5,7 $\mu \mathrm{L}$ de $\mathrm{NaOH} 3 \mathrm{M}$ e incubando la mezcla $10-15 \min$ a $37^{\circ} \mathrm{C}$. Se añadió entonces $1 \mu \mathrm{L}$ de glucógeno $10 \mathrm{mg} / \mathrm{ml}$ y $17 \mu \mathrm{L}$ de $\mathrm{AcNH}_{4} 10 \mathrm{M}$ y se precipitó el DNA con etanol absoluto frío, incubándolo a $-70^{\circ} \mathrm{C} 2,5 \mathrm{~h}$. Los pellets de DNA se lavaron con $450 \mu \mathrm{L}$ de etanol $70 \%$ frío y se resuspendieron en $30 \mu \mathrm{L}$ de $\mathrm{H}_{2} \mathrm{O}$. El rendimiento medio de este proceso es de 25 $\mathrm{ng} / \mu \mathrm{L}$ de DNA modificado por bisulfito.

\section{XII.3. AMPLIFICACIÓN DEL PROMOTOR Y SECUENCIACIÓN.}

Utilizando el programa informático (Methyl Primer Express), diseñamos unos oligonucleótidos para amplificar una región del promotor de CHN2 rica en CpGs una vez realizada la modificación por bisulfito del DNA (Tabla 12). Amplificamos el promotor utilizando GoTaq ${ }^{\circledR}$ Hot Start Polymerase (Promega) en las condiciones especificadas en la tabla.

Tabla 12: Secuencia de los oligonucleótidos y condiciones de la PCR de amplificación del promotor de $\beta 2$-quimerina bisulfitado. (F: Forward; R: Reverse)

\begin{tabular}{|c|c|c|c|}
\hline Oligonucleótido & Secuencia & $\begin{array}{c}\text { Tamaño de } \\
\text { la PCR }\end{array}$ & Condiciones PCR \\
\hline$\beta 2-$ met-F & 5' - GGG AGT TTA GGA GAG GGT - 3' & \multirow{2}{*}{$272 \mathrm{pb}$} & \multirow{2}{*}{$\begin{array}{c}60^{\circ} \text { anillamiento } \\
35 \text { ciclos } \\
1^{\prime} \text { elongación }\end{array}$} \\
\hline B2-met-R & 5' - ACA CTT СCT АCT CCA CCA AAT AA - 3' & & \\
\hline
\end{tabular}

Para poder secuenciar correctamente el promotor amplificado y poder observar metilaciones parciales, clonamos el producto de PCR en el vector pGEM-T Easy (Promega). Seleccionamos 6 colonias con inserto de cada una de las PCRs y las secuenciamos utilizando los oligonucleótidos universales T7 y SP6, que anillan en las regiones flanqueantes al polylinker del plásmido. 


\section{XII.4. DESMETILACIÓN DEL PROMOTOR POR TRATAMIENTO CON 5-AZA-2'- DEOXICITIDINA (AZA).}

Para estudiar si la metilación del promotor es el mecanismo de regulación de la expresión en las líneas celulares derivadas de tejido de mama estudiadas, tratamos las células con un agente desmetilante. Las células fueron incubadas con $1 \mu \mathrm{M}$ de AZA (5Aza-2'-deoxicitidina) durante 5 días, refrescando el medio cada 2 días. Ya que el AZA se resuspende en una dilución de ácido acético 1:1 para su uso en cultivo, en paralelo se mantuvo el crecimiento de un control de las células al que se le añadió la misma cantidad de dilución de ácido acético que a la muestra a estudio. 
RESULTADOS 



\section{ANÁLISIS MUTACIONAL DEL GEN CHN2.}

\section{I.1. BÚSQUEDA DE MUTACIONES PATOGÉNICAS DEL GEN CHN2 ASOCIADAS CON CÁNCER.}

Un gen supresor de tumores es aquél que codifica una proteína que se encarga de mantener el crecimiento celular controlado. Se han descrito algunas proteínas Rho-GAP que pueden actuar como genes supresores de tumores ya que, cuando se encuentran alteradas, dejan de ejerce su función de reguladores negativos, provocando la hiperactivación de las GTPasas, lo que favorece la aparición de procesos tumorales.

En el caso concreto de la $\beta 2$-quimerina, se ha descrito una disminución de la expresión en glioblastomas de alto grado respecto a gliomas de bajo grado y tejido cerebral sano ${ }^{164}$, y en tumores de mama respecto al tejido sano circundante ${ }^{90}$. En ciertos casos de síndromes mielodisplásicos se ha observado la aparición de una alteración citogenética que consiste en la monosomía total o parcial del cromosoma $7^{91}$, cromosoma en cuyo brazo corto se localiza el gen CHN2. Además, datos previos de nuestro laboratorio indican que es frecuente en estos síndromes alteraciones que incluyen traslocaciones y deleciones de la región cromosómica 7p15.3, que implican al locus del gen $C H N 2$. Ante estos datos decidimos buscar mutaciones en el gen $C H N 2$ que pudieran asociarse con la pérdida de función de la proteína $\beta 2$-quimerina en estos tipos de cáncer. Para ello, seleccionamos 23 muestras de sangre periférica de pacientes con síndrome mielodisplásico, 25 muestras de glioblastomas multiformes y 90 muestras de tumores de mama. Amplificamos por PCR los 13 exones del gen y sus regiones intrónicas adyacentes y mediante CSGE y secuenciación automática estudiamos si existen mutaciones en el gen CHN2.

En la figura 21 se muestran geles de CSGE representativos de las PCRs de los exones de distintos pacientes con patrones alterados. De las 13 regiones amplificadas se encontraron alteraciones en los exones 2, 4, 5 6, 7 y 10 o en sus regiones intrónicas circundantes. Así mismo se muestran los cromatogramas correspondientes a la secuenciación de las muestras con patrones alterados en las que se identifica cada mutación. 


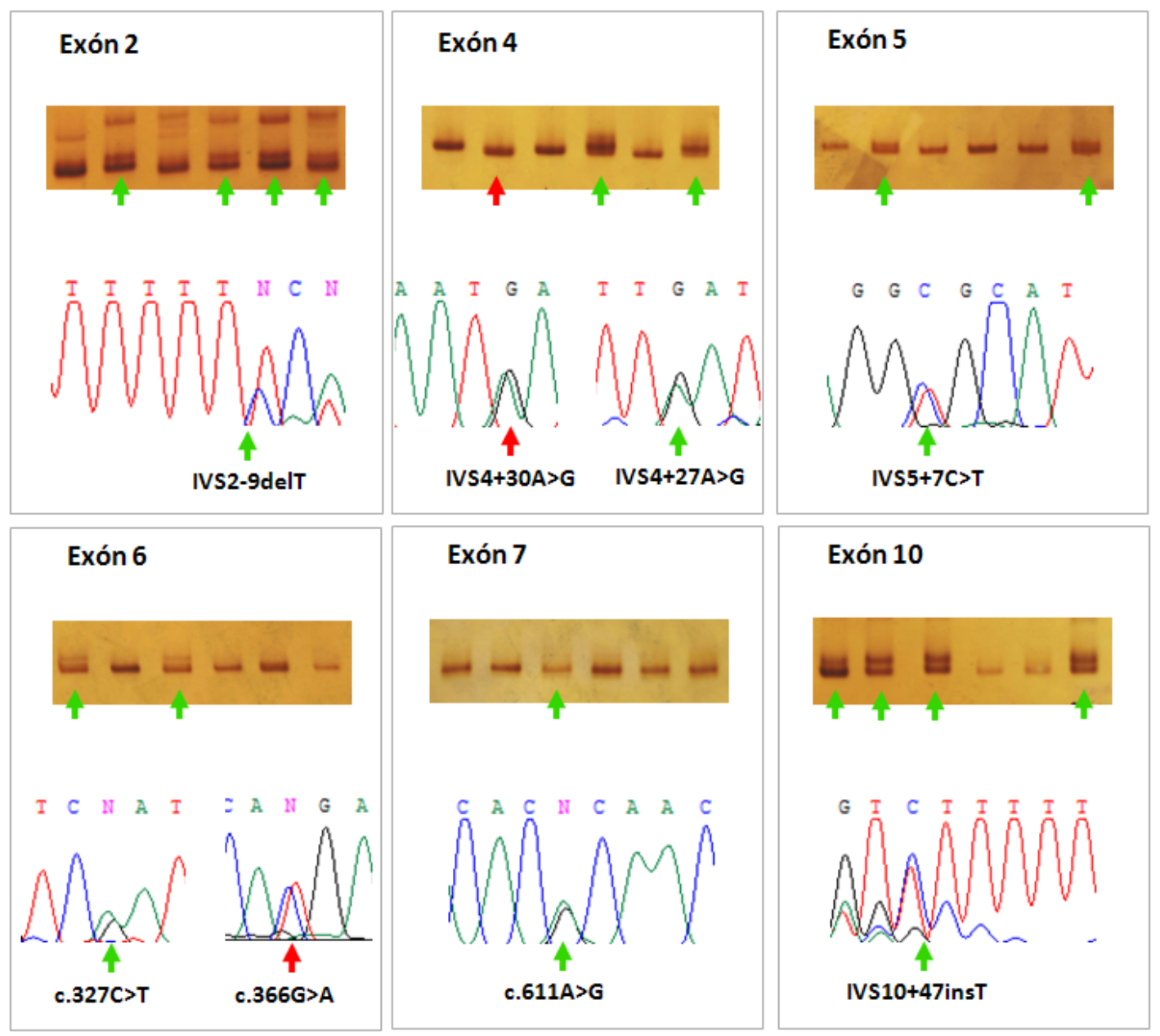

Figura 21: Geles de CSGE de los exones con patrones de migración alterados. Las flechas indican los pacientes con alteraciones. En la parte inferior se muestran los cromatogramas en los que se indica con una flecha la posición del cambio en la secuencia de nucleótidos de cada mutación que causa los distintos patrones de migración.

Este estudio nos permitió identificar ocho mutaciones, cinco exónicas y tres intrónicas, que se resumen en la tabla 13.

La deleción de uno o dos nucleótidos de timina en la posición -9 del intrón 1 (IVS2-9delT e IVS2-9del_TT), es una alteración muy frecuente en los pacientes con SMD y con glioblastomas incluidos en nuestro estudio. Se localiza en una región intrónica que no pertenece a la secuencia consenso de reconocimiento de la maquinaria de procesamiento del RNA. Esta alteración aparece descrita como un polimorfismo en la base de datos de SNPs (Single Nucleotide Polimorphisms ) del NCBI (rs34818186). 
Tabla 13: Mutaciones encontradas en los pacientes con síndrome mielodisplásico (SMD), glioblastoma multiforme (GB) y tumores de mama. (NA: No analizado).

\begin{tabular}{|c|c|c|c|c|c|c|}
\hline \multirow[b]{2}{*}{ Mutación } & \multirow{2}{*}{$\begin{array}{l}\text { Localización } \\
\text { en el gen }\end{array}$} & \multicolumn{3}{|c|}{ Número de casos } & \multirow[b]{2}{*}{ SNP } & \multirow[b]{2}{*}{ Descripción } \\
\hline & & SMD & GB & $\begin{array}{l}\text { Tumores } \\
\text { mama }\end{array}$ & & \\
\hline $\begin{array}{l}\text { IVS2-9delT } \\
\text { IVS2-9del_TT }\end{array}$ & Intrón 1 & $17 / 23(73,9 \%)$ & $18 / 25(72 \%)$ & NA & rs34818186 & $\begin{array}{l}\text { Deleción de Ts } \\
\text { en una zona de } \\
\text { repetición de } 12\end{array}$ \\
\hline IVS4+27A>G & Intrón 4 & $3 / 23(13 \%)$ & $7 / 25(28 \%)$ & NA & No descrito & $\begin{array}{l}\text { Cambio } \\
\text { intrónico }\end{array}$ \\
\hline IVS4+30A>G & Intrón 4 & $1 / 23(4,3 \%)$ & $2 / 25(8 \%)$ & NA & rs57232784 & $\begin{array}{l}\text { Cambio } \\
\text { intrónico }\end{array}$ \\
\hline IVS5+7C>T & Intrón 5 & $3 / 23(13 \%)$ & $3 / 25(12 \%)$ & NA & rs12112301 & $\begin{array}{c}\text { Cambio } \\
\text { intrónico de C } \\
\text { por T en región }\end{array}$ \\
\hline $\begin{array}{l}\text { c.327C>T } \\
\text { (p.H109H) }\end{array}$ & Exón 6 & $3 / 23(13 \%)$ & $2 / 25(8 \%)$ & NA & rs34045356 & $\begin{array}{c}\text { Cambio } \\
\text { silencioso }\end{array}$ \\
\hline $\begin{array}{l}\text { c.366G>A } \\
\text { (p.S122S) }\end{array}$ & Exón 6 & $1 / 23(4,3 \%)$ & $0 / 25(0 \%)$ & $1 / 90(1,1 \%)$ & No descrito & $\begin{array}{c}\text { Cambio } \\
\text { silencioso }\end{array}$ \\
\hline $\begin{array}{l}\text { c.611A>G } \\
\text { (p.H203R) }\end{array}$ & Exón 7 & $0 / 25(0 \%)$ & $1 / 25(4 \%)$ & NA & rs3750103 & Missense \\
\hline $\begin{array}{l}\text { IVS10+47insT } \\
\text { IVS10+47insTT }\end{array}$ & Intrón 10 & $19 / 23(82,6 \%)$ & $17 / 25(68 \%)$ & NA & No descrito & $\begin{array}{l}\text { Inserción de Ts } \\
\text { en una zona de } \\
\text { repetición de } 14\end{array}$ \\
\hline
\end{tabular}

En la región intrónica adyacente al exón 4 encontramos dos mutaciones de cambio de base: IVS4+27A>G e IVS4+30A>G que aparecen en varios casos de SMD y glioblastomas, tanto en homocigosis como en heterocigosis. Son mutaciones intrónicas, alejadas de los sitios de procesamiento del RNA. La mutación IVS4+30A>G ha sido descrita previamente como polimorfismo en la base de datos del NCBI (rs57232784). La mutación IVS4 $+27 A>G$ se describe por primera vez en este trabajo. Consideramos que es una variante no patogénica porque es un cambio de nucleótido fuera de regiones de procesamiento.

La mutación IVS5+7C>T, en la región intrónica adyacente al exón 5, aparece tanto en SMD como en glioblastomas. En la base de datos del NCBI (rs12112301) está descrita como un polimorfismo poblacional.

En el exón 6 detectamos dos mutaciones de cambio de base silenciosas. La mutación c.327C >T (p.H109H) aparece con frecuencia tanto en síndrome mielodisplásico como en glioblastomas. Está descrita en las bases de datos como un polimorfismo 
(rs34045356). El cambio de citosina por timina de la posición 366 (c.366G>A (p.S122S)), no descrito hasta el momento, fue encontrado en un caso de síndrome mielodisplásico en heterocigosis, y en un caso de los 90 estudiados en tumores de mama, también en heterocigosis.

La mutación c.611A>G (p.H203R), un cambio de nucleótido que se traduce en el cambio de una histidina por una arginina en la proteína, se observó en un caso de glioblastoma multiforme. Aparece descrita como un polimorfismo poblacional (rs3750103).

En el intrón 10 localizamos, en una zona de 14 repeticiones de timina, inserciones de 1 ó 2 timinas, IVS10+47insT e IVS10+47insTT, tanto en síndromes mielodisplásicos como en glioblastomas, que no han sido descritas hasta el momento. Se consideraron mutaciones no patogénicas por sus características: mutaciones intrónicas alejadas de la zona de procesamiento del RNA en una región de repetición de timinas.

En resumen, en el rastreo de mutaciones patogénicas del gen $C H N 2$, en los tipos de cáncer estudiados, hemos encontrado ocho mutaciones de las cuales cinco habían sido descritas previamente como polimorfismos en la base de datos del NCBI (http://www.ncbi.nlm.nih.gov/snp). Las tres mutaciones descritas por primera vez en este trabajo son cambios intrónicos o exónicos que no producen modificación de aminoácido. Debido a sus características no podemos considerar ninguna de estas mutaciones detectadas como mutaciones patogénicas implicadas de la aparición de estos tumores, sino que deben tratarse de polimorfismos poblacionales. Para analizar si alguno de estos polimorfismos se asocia con una mayor predisposición al desarrollo del cáncer, decidimos realizar el estudio poblacional que se describe a continuación.

\section{I.2. ANÁLISIS DE LOS POLIMORFISMOS DEL GEN CHN2.}

\section{2.a. Análisis de polimorfismos del gen CHN2 en pacientes con cáncer.}

Los cambios polimórficos en un gen pueden afectar a los niveles de transcripción, la estabilidad y la maduración del RNA, o a la función, expresión y plegamiento de la proteína, lo que puede dar lugar a pequeños cambios de su actividad. 
La búsqueda de mutaciones en el gen $\mathrm{CHN2}$ en muestras de tumores descritas en el apartado anterior no reveló ninguna alteración que pudiera explicar su implicación en el desarrollo del cáncer, pero si nos permitió caracterizar diversos polimorfismos del gen. Decidimos, por tanto, estudiar los polimorfismos más relevantes encontrados. Seleccionamos tres polimorfismos de los ocho encontrados por su posible implicación en la modificación de las características del gen CHN2. Elegimos el polimorfismo IVS5+7C>T (rs12112301), situado en la posición +7 del intrón 5 , porque aunque no se sitúa en la región de reconocimiento de la maquinaria de splicing, un cambio en esa posición podría afectar a la afinidad con la que las proteínas que intervienen en este proceso se unen a esta región del DNA. El polimorfismo c.366G>A (p.S122S) fue elegido porque es un cambio silencioso en la región codificante del exón 6 . Había sido detectado en un caso de SMD y en un caso de cáncer de mama. El tercer polimorfismo, c.611A>G (p.H203R) es un cambio de nucleótido en el exón 7, que genera un cambio del aminoácido histidina por arginina en la proteína. El cambio de aminoácido está localizado en una región cercana al inicio del dominio funcional C1 de la proteína; un dominio común para $\beta 1$ - y $\beta 2$ quimerina, y esencial para gran parte de sus funciones. Este polimorfismo ha sido descrito previamente (rs3750103) y aparece asociado con la predisposición a padecer esquizofrenia.

Los cinco polimorfismos restantes encontrados en el análisis de mutaciones del gen $\mathrm{CHN2}$ no se analizaron puesto que se trata de SNPs intrónicos lejanos a las regiones de splicing; a excepción del polimorfismo c.327C $>\mathrm{T}$ ( $\mathrm{p} . \mathrm{H} 109 \mathrm{H})$ que es un polimorfismo exónico. No obstante, este polimorfismo también se descartó porque ya aparecía descrito en las bases de datos de polimorfismos y sus frecuencias alélicas en los estudios poblacionales de las bases de datos eran similares a la encontrada en el estudio mutacional.

Para estudiar la posible de asociación de polimorfismos del gen CHN2 con cáncer, seleccionamos muestras de DNA obtenido a partir de sangre periférica de 23 casos de síndrome mielodisplásico. También estudiamos 144 muestras de sangre periférica de individuos con tumores del sistema nervioso central divididos en astrocitomas anaplásicos (22 pacientes), meningiomas (76 pacientes) y glioblastomas de alto grado (46 pacientes), y 161 muestras de sangre periférica de pacientes con cáncer de mama 
esporádico. Como controles seleccionamos muestras de sangre periférica de 218 individuos (125 mujeres y 93 hombres) que no padecían ningún tipo de cáncer en el momento del estudio. Los controles fueron comunes para los estudios de los tres tipos de cáncer; pero en el estudio de asociación con cáncer de mama sólo se utilizaron controles del sexo femenino, para excluir un sesgo por sexo.

Todos los grupos estudiados cumplían el equilibrio de Hardy-Weinberg, a excepción de la población control en el polimorfismo c.366G>A. Este es un polimorfismo con una frecuencia muy baja y la aparición de un único caso de genotipo homocigoto mutado (AA) debido al azar en la elección de los controles condiciona el equilibrio, impidiendo que la distribución del polimorfismo en nuestra población sea considerada como normal. Este dato se tuvo en cuenta a la hora de analizar las diferencias en la distribución de los genotipos entre grupos.

1.2.a.1 Estudio de asociación de los polimorfismos del gen CHN2 con síndrome mielodisplásico.

Se llevó a cabo el análisis de la distribución de genotipos de los tres polimorfismos estudiados entre los 23 pacientes con SMD y los 218 individuos control. Las frecuencias de los genotipos de los tres polimofismos estudiados se muestran en la figura 23A. En el polimorfismo IVS5+7C>T el alelo menos frecuente es el alelo T. Su frecuencia de aparición no supera el 5\% en homocigosis por lo que se agruparon lo genotipos con alelo T para su análisis estadístico. Lo mismo sucedió con el alelo A del polimorfismo c.366G>A (p.S122S) y el alelo $G$ del polimorfismo c.611A>G (p.H203R), ambos con frecuencias inferiores al $5 \%$ en homocigosis. Sobre los datos de frecuencia agrupados se realizaron los test estadísticos. En el caso del polimorfismo IVS5+7C>T se utilizó el test de Chi-cuadrado de Pearson porque la frecuencia de los genotipos agrupados era mayor al 5\%, obteniendo un valor de $p$ de 0,527 . Sin embargo, en los otros dos SNP se utilizó el test de Fisher al tener frecuencias que no superan el 5\%, con valores de $p$ de 0,915 para c.366G>A (p.S122S) y 0, 715 para c.611A>G (p.H203R) (Fig. 22B). Por lo tanto este análisis muestra que no existen diferencias estadísticamente significativas en la distribución de los genotipos entre pacientes con síndrome mielodisplásico y controles, revelando la ausencia de asociación de estos polimorfismos con la predisposición a desarrollar esta enfermedad. 


\begin{tabular}{|c|c|c|c|c|c|c|c|c|}
\hline \multicolumn{2}{|l|}{$\mathbf{A}$} & \multicolumn{3}{|c|}{ Distribución de los genotipos } & \multirow{2}{*}{ HWE } & \multicolumn{2}{|c|}{ Agrupación de genotipos } & \multirow{2}{*}{ Tota } \\
\hline & & cC & CT & $\mathrm{TT}$ & & CC & СТ у TT & \\
\hline \multirow{2}{*}{ IVS5+7C>T } & SMD & $20(87,0 \%)$ & $3(13,0 \%)$ & $0(0 \%)$ & 0,738 & $20(87,0 \%)$ & $3(13,0 \%)$ & 23 \\
\hline & Controles & $178(81,7 \%)$ & $38(17,4 \%)$ & $2(0,9 \%)$ & 0,986 & $178(81,7 \%)$ & $40(18,3 \%)$ & 218 \\
\hline & & GG & GA & AA & HWE & GG & GA y AA & Total \\
\hline \multirow{2}{*}{$\begin{array}{l}c .366 G>A \\
\text { (p.S122S) }\end{array}$} & SMD & $22(95,7 \%)$ & $1(4,3 \%)$ & $0(0 \%)$ & 0,915 & $22(95,7 \%)$ & $1(4,3 \%)$ & 23 \\
\hline & Controles & $212(98,6 \%)$ & $2(0,9 \%)$ & $1(0 \%)$ & $<0,01$ & $212(98,6 \%)$ & $3(1,4 \%)$ & 215 \\
\hline & & AA & AG & GG & HWE & AA & AG y GG & Total \\
\hline \multirow{2}{*}{$\begin{array}{l}\text { C.611A>G } \\
\text { (p.H203R) }\end{array}$} & SMD & $22(100 \%)$ & $0(0 \%)$ & $0(0 \%)$ & - & $22(100 \%)$ & $0(0 \%)$ & 22 \\
\hline & Controles & $194(90,7 \%)$ & $20(9,3 \%)$ & $0(0 \%)$ & 0,473 & $194(90,7 \%)$ & $20(9,3 \%)$ & 214 \\
\hline
\end{tabular}

B

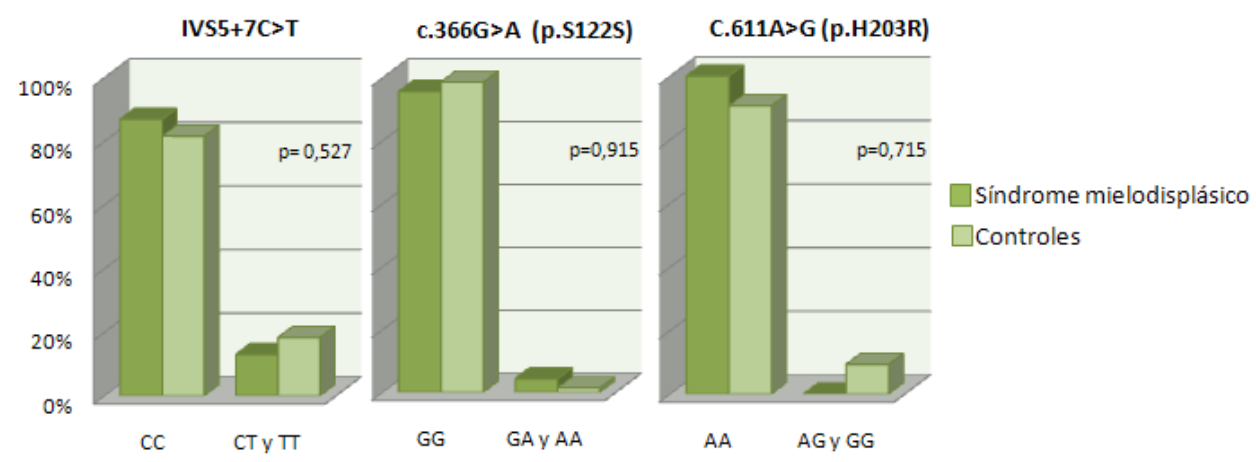

Figura 22: Distribución de los genotipos de los polimorfismos IVS5+7C >T, c.366G $>$ A (P.s122S) y c.611A>G (p.H203R) en los pacientes de síndrome mielodisplásico y los controles. (A) Tabla en la que se representan los porcentajes de los genotipos para los tres polimorfismos. (B) Análisis estadístico de la distribución de las agrupaciones de genotipos de los tres polimorfismos estudiados, entre pacientes y controles. El valor de $p$ se ha calculado utilizando el test de Chicuadrado de Pearson, excepto en el polimorfismo c.366G >A (p.S122S) que se utilizó el test de Fisher.

I.2.a.2 Estudio de asociación de los polimorfismos del gen CHN2 con los tumores del Sistema Nervioso Central.

Estudiamos la distribución de los genotipos de los tres polimorfismos seleccionados del gen $\mathrm{CHN} 2$ en muestras de sangre periférica de pacientes diagnosticados de tumores del sistema nervioso central y de individuos sanos (Fig. 23A).

Al igual que ocurrió en el caso anterior, los genotipos de los tres polimorfismos estudiados fueron agrupados para el análisis estadístico debido a la baja frecuencia de aparición del alelo menos común. En estos tumores, el alelo $\mathrm{G}$ del polimorfismo c.366G>A (p.S122S) presentó una frecuencia mayor del 5\%, a diferencia de la distribución 
observada en síndrome mielodisplásico, y por ello utilizamos el test estadístico de Chicuadrado de Pearson en vez del test de Fisher. Los otros polimorfismos presentaron frecuencias similares a las descritas en el estudio anterior, por lo que se analizaron utilizando los tests anteriormente mencionados para cada una de ellas (Pearson para IVS5+7C >T y Fisher para c.611A>G (p.H203R)).

\begin{tabular}{|c|c|c|c|c|c|c|c|c|}
\hline \multirow{2}{*}{$\mathbf{A}$} & & \multicolumn{3}{|c|}{ Distribución de los genotipos } & \multirow{2}{*}{ HWE } & \multicolumn{2}{|c|}{ Agrupación de genotipos } & \multirow{2}{*}{ Total } \\
\hline & & CC & Ст & $\mathrm{TT}$ & & cC & Ст у ТT & \\
\hline \multirow{3}{*}{ IVS5+7C>T } & Tumores SNC & $113(78,5 \%)$ & $30(20,8 \%)$ & $1(0,7 \%)$ & 0,512 & $113(78,5 \%)$ & $31(21,5 \%)$ & 144 \\
\hline & Controles & $178(81,7 \%)$ & $38(17,4 \%)$ & $2(0,9 \%)$ & 0,986 & $178(81,7 \%)$ & $40(18,3 \%)$ & 218 \\
\hline & & GG & GA & AA & HWE & GG & GA y AA & Total \\
\hline \multirow{3}{*}{$\begin{array}{l}\text { c.366G>A } \\
\text { (p.S122S) }\end{array}$} & Tumores SNC & $143(100 \%)$ & $0(0 \%)$ & $0(0 \%)$ & - & $143(100 \%)$ & $0(0 \%)$ & 143 \\
\hline & Controles & $212(98,6 \%)$ & $2(0,9 \%)$ & $2(0 \%)$ & $<0,01$ & $212(98,6 \%)$ & $3(1,4 \%)$ & 215 \\
\hline & & AA & AG & GG & HWE & AA & AG y GG & Total \\
\hline \multirow{2}{*}{$\begin{array}{l}\text { c.611A>G } \\
\text { (p.H203R) }\end{array}$} & Tumores SNC & $121(85,8 \%)$ & $19(13,5 \%)$ & $1(0,7 \%)$ & 0,79 & $121(85,8 \%)$ & $20(14,2 \%)$ & 141 \\
\hline & Controles & $194(90,7 \%)$ & $20(9,3 \%)$ & $0(0 \%)$ & 0,473 & $194(90,7 \%)$ & $20(9,3 \%)$ & 214 \\
\hline
\end{tabular}

B

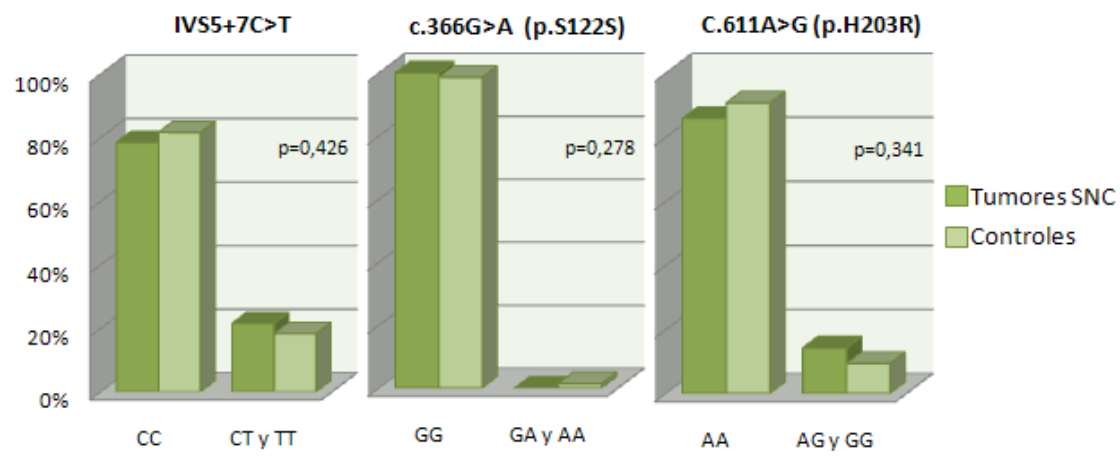

Figura 23: Distribución de los genotipos de los polimorfismos IVS5+7C >T, c.366G>A (P.s122S) y c.611A $>\mathrm{G}$ (p.H203R) en los pacientes diagnosticados de tumores del sistema nerviosos central y los controles. (A) Tabla en la que se representan los porcentajes de los genotipos para los tres polimorfismos. (B) Análisis estadístico de la distribución de las agrupaciones de genotipos de los tres polimorfismos estudiados, entre pacientes y controles. Valor de $p$ hayado utilizando el test de Chi-cuadrado de Pearson, excepto en el polimorfismo c.366G>A (p.S122S) que se utilizó el test de Fisher.

Tras los análisis estadísticos obtuvimos unos valores de $p$ para el polimorfismo IVS5+7C $>$ T de 0,426, de 0,278 para el polimorfismo c.366G $>$ A (p.S122S) y un valor de $p$ de 0,341 en el caso del estudio del polimorfismo c.611A>G (p.H203R). Estos resultados muestran que no existen diferencias estadísticamente significativas en la distribución de los polimorfismos entre las dos poblaciones comparadas (Fig. 23B). 
Los tumores analizados en este estudio tienen unas características histológicas, celulares y moleculares muy heterogéneas. Estudios previos asocian la alteración de $\beta 2$ quimerina con la progresión tumoral en tumores de sistema nervioso central, de manera que estas alteraciones aparecen solamente en glioblastomas multiformes.

Teniendo en cuenta estos datos decidimos realizar este estudio dividiendo los pacientes según el tipo de tumor: astrocitomas, meningiomas y glioblastomas, tal y como se detalla en la figura 24A. Comparamos cada subgrupo tumoral con la población control. Los resultados del análisis estadístico no muestran asociación de los polimorfismos estudiados con la predisposición al desarrollo de ninguno de estos tipos específicos de tumor, incluido los glioblastomas multiformes (Fig. 24B).

\begin{tabular}{|c|c|c|c|c|c|c|c|c|}
\hline \multirow{2}{*}{\multicolumn{2}{|c|}{$\mathbf{A}$}} & \multicolumn{3}{|c|}{ Distribución de los genotipos } & \multirow{2}{*}{ HWE } & \multicolumn{2}{|c|}{ Agrupación de genotipos } & \multirow{2}{*}{ Total } \\
\hline & & CC & CT & TT & & CC & СТ у TT & \\
\hline \multirow{4}{*}{ IVS5+7C>T } & AC & $16(72,7 \%)$ & $6(27,3 \%)$ & $0(0 \%)$ & 0,459 & $16(72,7 \%)$ & $6(27,3 \%)$ & 22 \\
\hline & MG & $62(81,6 \%)$ & $14(18,4 \%)$ & $0(0 \%)$ & 0,376 & $62(81,6 \%)$ & $14(18,4 \%)$ & 76 \\
\hline & GB & $35(76,1 \%)$ & $10(21,7 \%)$ & $1(2,2 \%)$ & 0,777 & $35(76,1 \%)$ & $11(23,9 \%)$ & 46 \\
\hline & Controles & $178(81,7 \%)$ & $38(17,4 \%)$ & $2(0,9 \%)$ & 0,986 & $178(81,7 \%)$ & $40(18,3 \%)$ & 218 \\
\hline & & GG & GA & AA & HWE & GG & GA y AA & Total \\
\hline \multirow{4}{*}{$\begin{array}{l}c .366 G>A \\
(p . S 122 S)\end{array}$} & AC & $22(100 \%)$ & $0(0 \%)$ & $0(0 \%)$ & - & $22(100 \%)$ & $0(0 \%)$ & 22 \\
\hline & MG & 75 (100\%) & $0(0 \%)$ & $0(0 \%)$ & - & $75(100 \%)$ & $0(0 \%)$ & 75 \\
\hline & GB & $46(100 \%)$ & $0(0 \%)$ & $0(0 \%)$ & - & $46(100 \%)$ & $0(0 \%)$ & 46 \\
\hline & Controles & $212(98,6 \%)$ & $2(0,9 \%)$ & $2(0 \%)$ & $<0,01$ & $212(98,6 \%)$ & $3(1,4 \%)$ & 215 \\
\hline & & AA & AG & GG & HWE & AA & AG y GG & Total \\
\hline \multirow{4}{*}{$\begin{array}{l}\text { C.611A>G } \\
\text { (p.H203R) }\end{array}$} & $A C$ & $18(81,8 \%)$ & $3(13,6 \%)$ & $1(4,5 \%)$ & 0,13 & $18(81,8 \%)$ & $4(18,2 \%)$ & 22 \\
\hline & MG & $65(86,7 \%)$ & $10(13,3 \%)$ & $0(0 \%)$ & 0,536 & $65(86,7 \%)$ & $10(13,3 \%)$ & 75 \\
\hline & GB & $38(86,4 \%)$ & $6(13,6 \%)$ & $0(0 \%)$ & 0,627 & $38(86,4 \%)$ & $6(13,6 \%)$ & 44 \\
\hline & Controles & $194(90,7 \%)$ & $20(9,3 \%)$ & $0(0 \%)$ & 0,473 & $194(90,7 \%)$ & $20(9,3 \%)$ & 214 \\
\hline
\end{tabular}

B

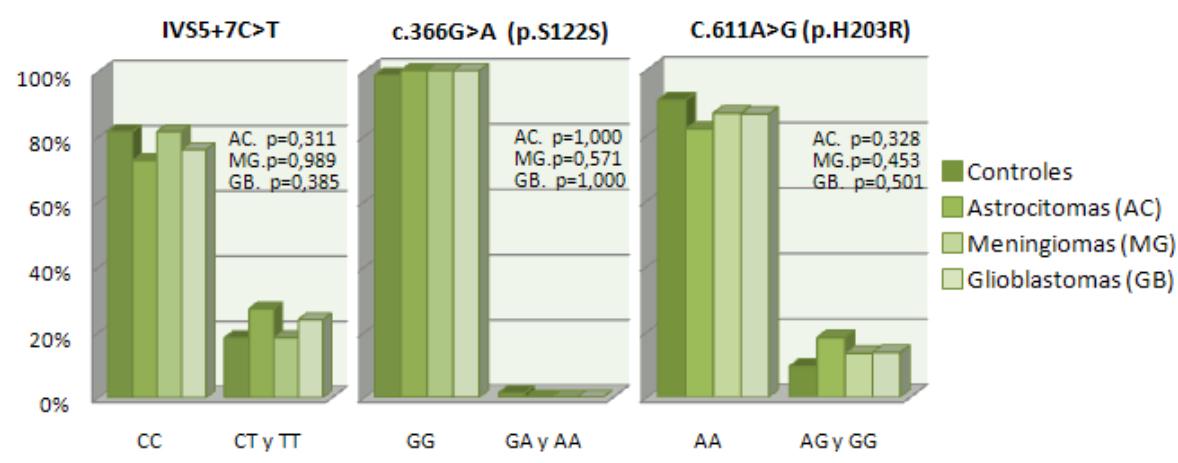

Figura 24: Distribución de los genotipos de los polimorfismos IVS5+7C >T, c.366G>A (P.s122S) y c.611A>G (p.H203R) en los subgrupos depacientes diagnosticados de tumores del sistema nerviosos central, divididos en astrocitomas (AC), meningiomas (MG) y glioblastomas (GB), y los controles. (A) Tabla en la que se representan los porcentajes de los genotipos para los tres polimorfismos. (B) Análisis estadístico de la distribución de las agrupaciones de genotipos de los tres polimorfismos estudiados, entre subgrupos de pacientes y controles. Valor de $p$ hayado utilizando el test de Chi-cuadrado de Pearson, excepto en el polimorfismo c.366G>A (p.S122S) que se utilizó el test de Fisher. 
I.2.a.3 Estudio de asociación de los polimorfismos del gen CHN2 con el cáncer de mama.

El tipo tumoral en el que más frecuentemente se han observado alteraciones de la ß2-quimerina es el cáncer de mama. Para estudiar la contribución de las variaciones polimórficas del gen con el desarrollo de esta enfermedad, estudiamos las distribuciones de los genotipos de los tres polimorfismos del gen CHN2 en 212 muestras de sangre periférica de mujeres con cáncer de mama, frente a 153 mujeres que no tenían antecedentes de cáncer (Figura 25A).

\begin{tabular}{|c|c|c|c|c|c|c|c|c|}
\hline \multirow{2}{*}{\multicolumn{2}{|c|}{ A }} & \multicolumn{3}{|c|}{ Distribución de los genotipos } & \multirow{2}{*}{ HWE } & \multicolumn{2}{|c|}{ Agrupación de genotipos } & \multirow{2}{*}{ Total } \\
\hline & & CC & CT & $\mathrm{TT}$ & & CC & СТ у ТT & \\
\hline \multirow{2}{*}{ IVS5+7C>T } & C. mama & $179(84,4 \%)$ & $30(14,2 \%)$ & $3(1,4 \%)$ & 0,193 & $179(84,4 \%)$ & $33(15,6 \%)$ & 212 \\
\hline & Controles & $125(81,7 \%)$ & $26(17 \%)$ & $2(1,3 \%)$ & 0,628 & $125(81,7 \%)$ & $28(18,3 \%)$ & 153 \\
\hline & & GG & GA & AA & HWE & GG & GA y AA & Total \\
\hline \multirow{2}{*}{$\begin{array}{l}c .366 G>A \\
\text { (p.S122S) }\end{array}$} & C. mama & $203(98,1 \%)$ & $4(1,9 \%)$ & $0(0 \%)$ & 0,888 & $203(98,1 \%)$ & $4(1,9 \%)$ & 207 \\
\hline & Controles & $150(99,3 \%)$ & $0(0 \%)$ & $1(0,7 \%)$ & $<0,01$ & $150(99,3 \%)$ & $1(0,7 \%)$ & 151 \\
\hline & & AA & AG & GG & HWE & AA & AG y GG & Total \\
\hline \multirow{2}{*}{$\begin{array}{l}\text { C.611A>G } \\
\text { (p.H203R) }\end{array}$} & C. mama & $192(89,7 \%)$ & $22(10,3 \%)$ & $0(0 \%)$ & 0,428 & $192(89,7 \%)$ & $22(10,3 \%)$ & 214 \\
\hline & Controles & $135(89,4 \%)$ & $16(10,6 \%)$ & $0(0 \%)$ & 0,492 & $135(89,4 \%)$ & $16(10,6 \%)$ & 151 \\
\hline
\end{tabular}

\section{B}

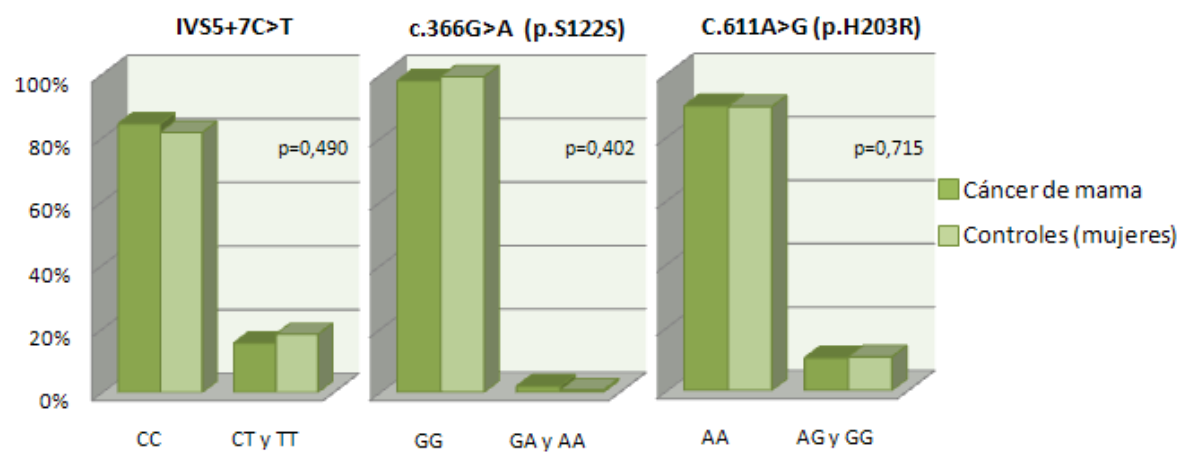

Figura 25: Distribución de los genotipos de los polimorfismos IVS5+7C>T, c.366G >A (P.s122S) y c.611A $>G$ (p.H203R) en los pacientes diagnosticados de tumores de mama. (A) Tabla en la que se representan los porcentajes de los genotipos para los tres polimorfismos. (B) Análisis estadístico de la distribución de las agrupaciones de genotipos de los tres polimorfismos estudiados, entre pacientes y controles. El valor de $p$ se ha calculado utilizando el test de Chi-cuadrado de Pearson, excepto en el polimorfismo c.366G>A (p.S122S) que se utilizó el test de Fisher.

Al igual que en los casos anteriores, los datos de los genotipos fueron agrupados debido a la baja presencia del alelo menos común. Buscamos diferencias en la distribución de los grupos de genotipos de cada polimorfismo entre pacientes y controles 
utilizando los test estadísticos de Chi-cuadrado de Pearson y el test de Fisher. No hemos observado diferencias estadísticamente significativas en ninguno de los tres polimorfismos estudiados (Fig. 25B).

En resumen, no observamos asociación de los tres polimorfismos del gen CHN2 seleccionados con los tipos de cáncer estudiados en este trabajo. No obstante, cabe destacar que el polimorfismo c.611A>G (p.H203R) en síndromes mielodisplásicos muestra una frecuencia de aparición del alelo $\mathrm{G}$ menor que la observada en el resto de las poblaciones estudiadas, tanto controles como pacientes con otros tipos tumorales. Esta diferencia no muestra significación estadística probablemente debido al pequeño tamaño poblacional analizado. No descartamos que se demuestre la asociación de este polimorfismo con el síndrome mielodisplásico al aumentar el número de casos.

Ante la ausencia de asociación de los polimorfismos estudiados con el desarrollo de cáncer decidimos comprobar si las variaciones polimórficas del gen CHN2 son relevantes en el desarrollo de otras enfermedades relacionadas con la función de la quimerina $\beta 2$.

\section{2.b. Análisis de los polimorfismos del gen CHN2 en drogodependencias.}

Además del posible papel de las quimerinas como genes supresores de tumores, estas proteínas, a través de su acción reguladora sobre Rac, tienen funciones relacionadas con el desarrollo del sistema nervioso. Rac está asociada con la regulación de la plasticidad estructural de las espinas y las dendritas, y aparece implicada en procesos neuronales como la migración y polarización neuronal, la orientación axonal y la formación de la sinapsis neuronal. No es, por tanto, extraño que mutaciones en reguladores $y$ efectores de esta GTPasa estén asociadas con trastornos neurodegenerativos o con alteraciones de la neurogénesis. Un ejemplo son las quimerinas, ya que recientemente se ha descrito que mutaciones en el gen $\mathrm{CHN1}$ que alteran la función de a2-quimerina son las responsables del desarrollo del denominado síndrome de la retracción de Duane $e^{165}$. No se conoce hasta el momento si existen alteraciones similares en el gen CHN2 asociadas a trastornos neuronales. Sin embargo, se ha observado una asociación de este gen con la adicción al tabaco en un análisis de GWAS 
(Genome-wide $\underline{\text { Association Study) }}{ }^{129}$, indicando que $\beta 2$-quimerina puede ser relevante en los comportamientos adictivos.

Teniendo en cuenta estos datos, en este trabajo hemos estudiado una posible asociación entre polimorfismos del gen CHN2 y la adicción al tabaco y al alcohol, dos sustancias cuya adicción está relacionada ${ }^{166}$.

\section{2.b.1 Asociación de los polimorfismos del gen CHN2 y el tabaquismo.}

Hemos estudiado tres polimorfismos del gen $\mathrm{CHN2}$ : IVS5+7C $>\mathrm{T}$, c.366G $>\mathrm{A}$ (p.S122S) y c.611A>G (p.H203R) en 188 fumadores y 198 individuos no fumadores (Fig. 26A). La distribución del polimorfismo c.366G>A (p.S122) no estaba en equilibrio de Hardy-Weinberg en los casos de fumadores (Fig. 26A). En el resto de los polimorfismos mantenían el equilibrio en la distribución de los genotipos.

\begin{tabular}{|c|c|c|c|c|c|c|c|c|}
\hline \multirow[t]{2}{*}{$\mathbf{A}$} & & \multicolumn{3}{|c|}{ Distribución de los genotipos } & \multirow{2}{*}{ HWE } & \multicolumn{2}{|c|}{ Agrupación de genotipos } & \multirow{2}{*}{ Total } \\
\hline & & CC & CT & $\mathrm{TT}$ & & CC & СТ у ТТ & \\
\hline \multirow{3}{*}{ IVS5+7C>T } & Fumadores & $148(78,7 \%)$ & $40(21,3 \%)$ & $0(0 \%)$ & 0,103 & $148(78,7 \%)$ & $40(21,3 \%)$ & 188 \\
\hline & No fumadores & $154(79,8 \%)$ & $36(18,6 \%)$ & $3(1,5 \%)$ & 0,596 & $154(79,8 \%)$ & $39(20,2 \%)$ & 193 \\
\hline & & GG & GA & AA & HWE & GG & GA y AA & Total \\
\hline \multirow{3}{*}{$\begin{array}{l}\text { c.366G }>A \\
\text { (p.S122S) }\end{array}$} & Fumadores & $170(95,5 \%)$ & $7(3,9 \%)$ & $1(0,6 \%)$ & $<0,05$ & $170(95,5 \%)$ & $8(4,5 \%)$ & 178 \\
\hline & No fumadores & $196(100 \%)$ & $0(0 \%)$ & $0(0 \%)$ & - & $196(100 \%)$ & $0(0 \%)$ & 196 \\
\hline & & AA & AG & GG & HWE & AA & AG y GG & Total \\
\hline \multirow{2}{*}{$\begin{array}{l}\text { c.611A>G } \\
\text { (p. } \mathrm{H} 203 R)\end{array}$} & Fumadores & $169(90,4 \%)$ & $18(9,6 \%)$ & $0(0 \%)$ & 0,489 & $169(90,4 \%)$ & $18(9,6 \%)$ & 187 \\
\hline & No fumadores & $172(86,9 \%)$ & $26(13,1 \%)$ & $0(0 \%)$ & 0,323 & $172(86,9 \%)$ & $26(13,1 \%)$ & 198 \\
\hline
\end{tabular}

\section{B}

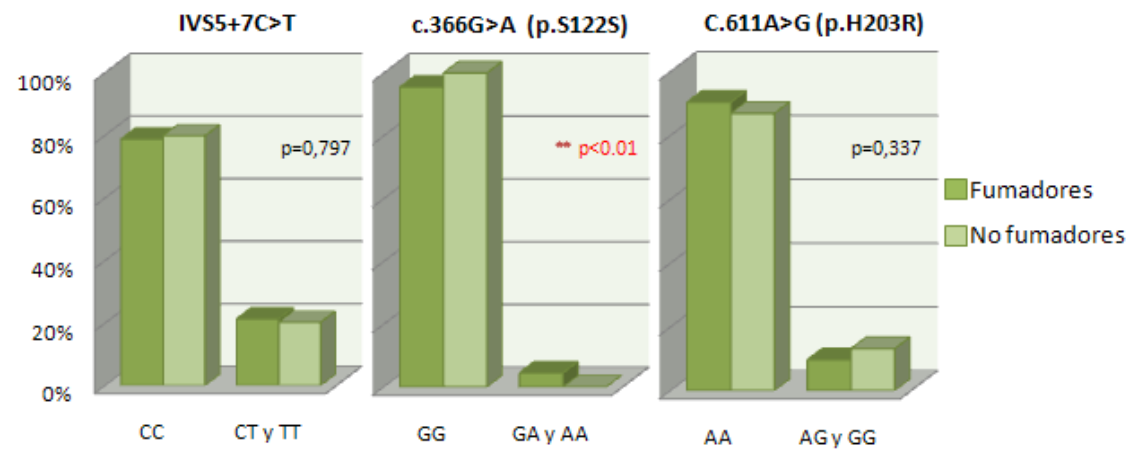

Figura 26: Distribución de los genotipos de los polimorfismos IVS5+7C>T, c.366G>A (p.S122S) y c.611A>G (p.H203R) en fumadores y no fumadores. (A) Tabla en la que se representan los porcentajes de los genotipos para los tres polimorfismos. (B) Análisis estadístico de la distribución de las agrupaciones de genotipos de los tres polimorfismos estudiados entre fumadores y controles. El valor de $p$ se hayó utilizando el test de Chi-cuadrado de Pearson, excepto en el polimorfismo c.366G>A (p.S122S) en el que se utilizó el test de Fisher. 
Como ya ocurriera en casos anteriores, las frecuencias de aparición de los genotipos menos comunes fueron inferiores al 5\%, por lo que se agruparon los genotipos en torno al alelo menos frecuente para realizar los análisis estadísticos (Chi-cuadrado de Pearson y test de Fisher).

Los estudios de los polimorfismos IVS5+7C >T y c.611A >G (p.H203R) revelaron que no existe asociación de estos dos polimorfismos con la adicción al tabaco (Fig. 26B). Sin embargo, el polimorfismo c.366G>A (p.S122S) mostró una discreta asociación entre el alelo A y el consumo de tabaco ( $p<0,01 ;$ Odss Ratio= 1,047 [1,014-1,089]).

\begin{tabular}{|c|c|c|c|c|c|c|c|c|}
\hline \multirow{2}{*}{ A } & \multirow{2}{*}{$\begin{array}{l}\text { Cigarrillos } \\
\text { /día }\end{array}$} & \multicolumn{3}{|c|}{ Distribución de los genotipos } & \multirow{2}{*}{ HWE } & \multicolumn{2}{|c|}{ Agrupación de } & \multirow{2}{*}{ Total } \\
\hline & & CC & CT & $\mathrm{TT}$ & & $\mathrm{CC}$ & Ст у ТT & \\
\hline \multirow{2}{*}{ IVS5+7C>T } & $>\mathbf{2 0}$ & $56(78,9 \%)$ & $15(21,1 \%)$ & $0(0 \%)$ & 0,320 & $56(78,9 \%)$ & $15(21,1 \%)$ & 71 \\
\hline & $\leq \mathbf{2 0}$ & $81(78,6 \%)$ & $22(21,4 \%)$ & $0(0 \%)$ & 0,225 & $81(78,6 \%)$ & $22(21,4 \%)$ & 103 \\
\hline & & GG & GA & AA & HWE & GG & GA y AA & Total \\
\hline \multirow{2}{*}{$\begin{array}{l}c .366 G>A \\
\text { (p.S122S) }\end{array}$} & $>20$ & $69(97,2 \%)$ & $2(2,8 \%)$ & $0(0 \%)$ & 0,904 & $69(97,2 \%)$ & $2(2,8 \%)$ & 71 \\
\hline & $\leq 20$ & $91(93,8 \%)$ & $5(5,1 \%)$ & 1 & 0,011 & $91(93,8 \%)$ & $6(6,2 \%)$ & 97 \\
\hline & & AA & AG & GG & HWE & AA & AG y GG & Total \\
\hline \multirow{2}{*}{$\begin{array}{l}c .611 A>G \\
\text { (p.H203R) }\end{array}$} & $>20$ & $61(85,9 \%)$ & $10(14,1 \%)$ & $0(0 \%)$ & 0,523 & $61(85,9 \%)$ & $10(14,1 \%)$ & 71 \\
\hline & $\leq \mathbf{2 0}$ & $97(94,2 \%)$ & $6(5,8 \%)$ & $0(0 \%)$ & 0,761 & $97(94,2 \%)$ & $6(5,8 \%)$ & 103 \\
\hline
\end{tabular}

B

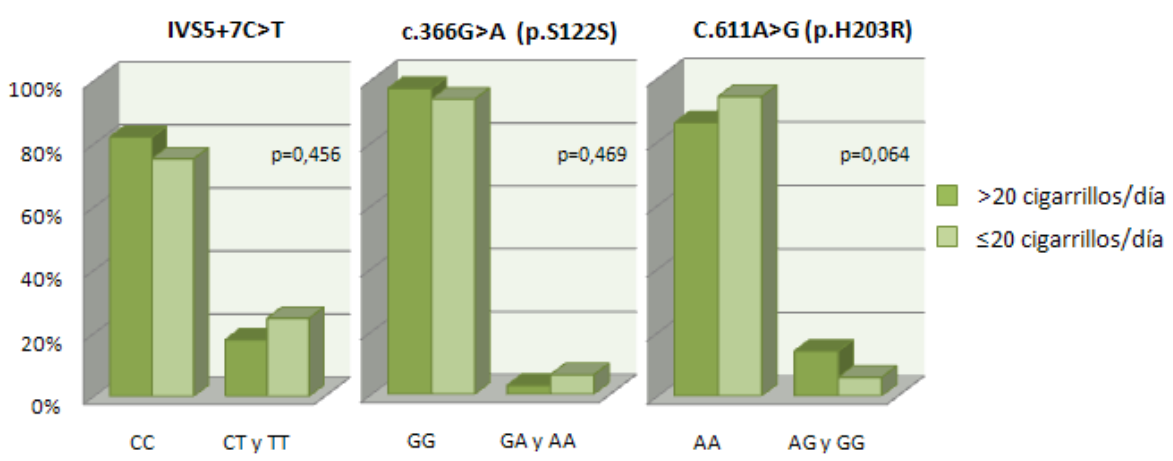

Figura 27: Distribución de los genotipos de los polimorfismos IVS5+7C $>T, c .366 G>A$ (p.S122S) y c.611A>G (p.H203R) en fumadores divididos según el número de cigarrillos consumidos al día. (A) Tabla en la que se representan los porcentajes de los genotipos para los tres polimorfismos. (B) Análisis estadístico de la distribución de las agrupaciones de genotipos de los tres polimorfismos estudiados. El valor de $p$ se hayó utilizando el test de Chi-cuadrado de Pearson, excepto en el polimorfismo c.366G>A (p.S122S) en el que se utilizó el test de Fisher. 
Para comprobar si esta asociación del tabaquismo con el gen CHN2 tiene relación con la cantidad de nicotina aspirada al día, comparamos los datos de los fumadores entre sí agrupándolos según la cantidad de cigarrillos consumidos por día: más de 20 cigarrillos al día o menos (Fig. 27A). Se compararon también los genotipos de los polimorfismos del gen CHN2 entre fumadores de distintas edades para observar si existía relación del polimorfismo con la persistencia en el tiempo con el consumo de tabaco. En este caso, dividimos los fumadores en dos subpoblaciones: mayores y menores de 65 años (Fig. 28A).

\begin{tabular}{|c|c|c|c|c|c|c|c|c|}
\hline \multirow{2}{*}{$\mathbf{A}$} & \multirow{2}{*}{$\begin{array}{c}\text { Edad } \\
\text { fumadores }\end{array}$} & \multicolumn{3}{|c|}{ Distribución de los genotipos } & \multirow{2}{*}{ HWE } & \multicolumn{2}{|c|}{ Agrupación de genotipos } & \multirow{2}{*}{ Tota } \\
\hline & & $\mathrm{CC}$ & CT & $\mathrm{TT}$ & & cC & СТ у ТT & \\
\hline \multirow{3}{*}{ IVS5+7C>T } & $>65$ años & $78(82,1 \%)$ & $17(17,9 \%)$ & $0(0 \%)$ & 0,338 & $78(82,1 \%)$ & $17(17,9 \%)$ & 95 \\
\hline & $\leq 65$ años & $70(75,3 \%)$ & $23(24,7 \%)$ & $0(0 \%)$ & 0,174 & $70(75,3 \%)$ & $23(24,7 \%)$ & 93 \\
\hline & & GG & GA & AA & HWE & GG & GA y AA & Total \\
\hline \multirow{3}{*}{$\begin{array}{l}c .366 G>A \\
\text { (p.S122S) }\end{array}$} & $>65$ años & $87(92,5 \%)$ & $6(6,4 \%)$ & $1(1,1 \%)$ & 0,036 & $87(92,5 \%)$ & $7(7,5 \%)$ & 94 \\
\hline & $\leq 65$ años & $83(98,8 \%)$ & $1(1,2 \%)$ & $0(0 \%)$ & 0,956 & $83(98,8 \%)$ & $1(1,2 \%)$ & 84 \\
\hline & & AA & AG & GG & HWE & AA & AG y GG & Total \\
\hline \multirow{2}{*}{$\begin{array}{l}c .611 A>G \\
(p . H 203 R)\end{array}$} & $>65$ años & $86(90,5 \%)$ & $9(9,5 \%)$ & $0(0 \%)$ & 0,628 & $86(90,5 \%)$ & $9(9,5 \%)$ & 95 \\
\hline & $\leq 65$ años & $83(90,2 \%)$ & $9(9,8 \%)$ & $0(0 \%)$ & 0,622 & $83(90,2 \%)$ & $9(9,8 \%)$ & 92 \\
\hline
\end{tabular}

B

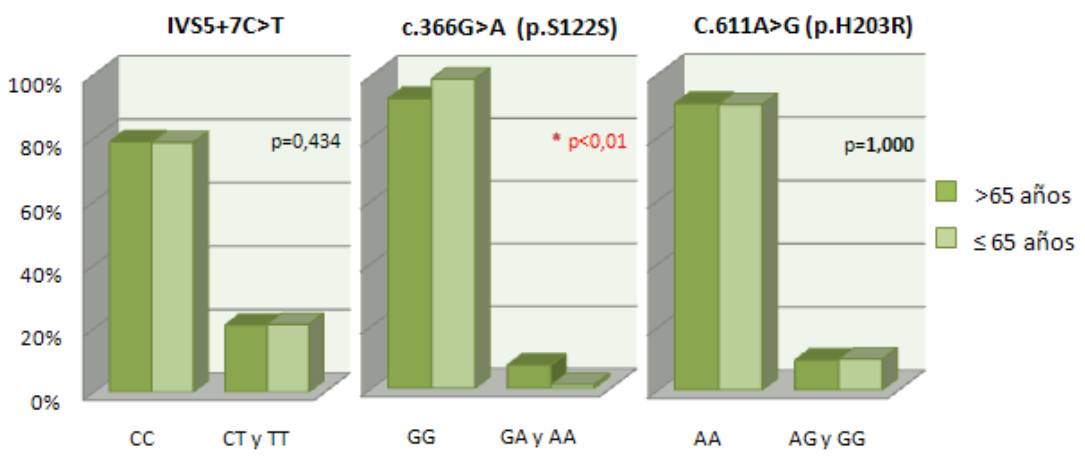

Figura 28: Distribución de los genotipos de los polimorfismos IVS5+7C $>T, c .366 G>A$ (p.S122S) y c.611A>G (p.H203R) en subgrupos de fumadores divididos según la edad. (A) Tabla en la que se representan los porcentajes de los genotipos para los tres polimorfismos. (B) Análisis estadístico de la distribución de las agrupaciones de genotipos de los tres polimorfismos estudiados. El valor de $p$ se hayó utilizando el test de Chi-cuadrado de Pearson, excepto en el polimorfismo c.366G >A (p.S122S) en el que se utilizó el test de Fisher. 
El análisis estadístico realizado en estudio de los polimorfismos IVS5+7C>T y c.611A>G (p.H203R) no mostró asociación entre estos polimorfismos con el consumo en nicotina o con la edad del fumador (Fig. 27B y 28B). Sin embargo, sí observamos una relación estadísticamente significativa entre portar el alelo A del polimorfismo c.366G>A (p.S122) y los fumadores mayores de 65 años (Fig. 28B) de manera que la probabilidad de que un fumador llegue a edades avanzadas y continúe con el consumo de tabaco es 6 veces mayor si el individuo porta el alelo A de este polimorfismo ( $p=0,046$; Odds ratio: $6,678[0,804-55,457])$.

Nuestros estudios muestran, por tanto, una asociación del gen $C H N 2$, a través del polimorfismo c.366G>A (p.S122), con el consumo de tabaco; más concretamente con el mantenimiento del consumo hasta edades avanzadas.

Es muy frecuente que el consumo de tabaco esté relacionado con el abuso de alcohol. Está bien documentado que en ambas adicciones influyen factores genéticos comunes, existiendo variantes alélicas de diversos genes asociadas tanto al tabaquismo como al alcoholismo ${ }^{167}$. Teniendo en cuenta estos datos, decidimos ampliar el estudio de los tres polimorfismos del gen CHN2 a individuos alcohólicos.

\section{2.b.2 Asociación de los polimorfismos del gen CHN2 y el alcoholismo.}

Para estudiar la posible asociación de los tres polimorfismos del gen CHN2 con la adicción al alcohol seleccionamos 278 individuos alcohólicos y 143 individuos abstemios (Fig. 29A). En el caso del polimorfismo c.366G>A (p.S122S) no se encontraron casos o controles portadores del alelo $\mathrm{A}$, por lo que no se pudo realizar el estudio estadístico de comparación de las frecuencias de los genotipos. En el caso de los otros dos polimorfismos, los genotipos se agruparon para su análisis estadístico siguiendo los criterios de los casos anteriores.

Al igual que en el estudio en fumadores, al comparar los datos de agrupación alélica de los polimorfismos IVS5+7C>T y c.611A>G (p.H203R) entre los alcohólicos y los controles, no encontramos diferencias estadísticamente significativas en su distribución (Fig. 29B). Tampoco se encontraron diferencias en el polimorfismo c.366G>A (p.S122S), puesto que todos los casos y controles presentaban el genotipo GG. Por lo tanto este polimorfismo está específicamente asociado con el consumo de tabaco. 


\begin{tabular}{|c|c|c|c|c|c|c|c|c|}
\hline \multirow[t]{2}{*}{$\mathbf{A}$} & & \multicolumn{3}{|c|}{ Distribución de los genotipos } & \multirow{2}{*}{ HWE } & \multicolumn{2}{|c|}{ Agrupación de genotipos } & \multirow{2}{*}{ Total } \\
\hline & & $\mathrm{CC}$ & CT & $\mathrm{TT}$ & & $\mathrm{CC}$ & СТ у TT & \\
\hline \multirow{3}{*}{ IVS5+7C>T } & Alcohólicos & $228(82,1 \%)$ & $46(16,5 \%)$ & $4(1,4 \%)$ & 0,346 & $228(82,1 \%)$ & $50(18,0 \%)$ & $278(100 \%)$ \\
\hline & Controles & $112(81,2 \%)$ & $25(18,1 \%)$ & $1(0,7 \%)$ & 0,757 & $112(81,2 \%)$ & $26(18,8 \%)$ & $138(100 \%)$ \\
\hline & & GG & GA & AA & HWE & GG & GA y AA & Total \\
\hline$>A$ & Alcohólicos & $277(100 \%)$ & $0(0 \%)$ & $0(0 \%)$ & - & $277(100 \%)$ & $0(0 \%)$ & $277(100 \%)$ \\
\hline \multirow[t]{2}{*}{ (p.S122S) } & Controles & $141(100 \%)$ & $0(0 \%)$ & $0(0 \%)$ & - & $141(100 \%)$ & $0(0 \%)$ & $141(100 \%)$ \\
\hline & & AA & AG & GG & HWE & AA & AG y GG & Total \\
\hline c. $611 \mathrm{~A}>\mathrm{G}$ & Alcohólicos & $252(91,0 \%)$ & $26(9,0 \%)$ & $0(0 \%)$ & 0,413 & $252(91,0 \%)$ & $26(9,0 \%)$ & $278(100 \%)$ \\
\hline (p.H203R) & Controles & $122(85,3 \%)$ & $21(14,7 \%)$ & $0(0 \%)$ & 0,343 & $122(85,3 \%)$ & $21(14,7 \%)$ & $143(100 \%)$ \\
\hline
\end{tabular}

\section{B}

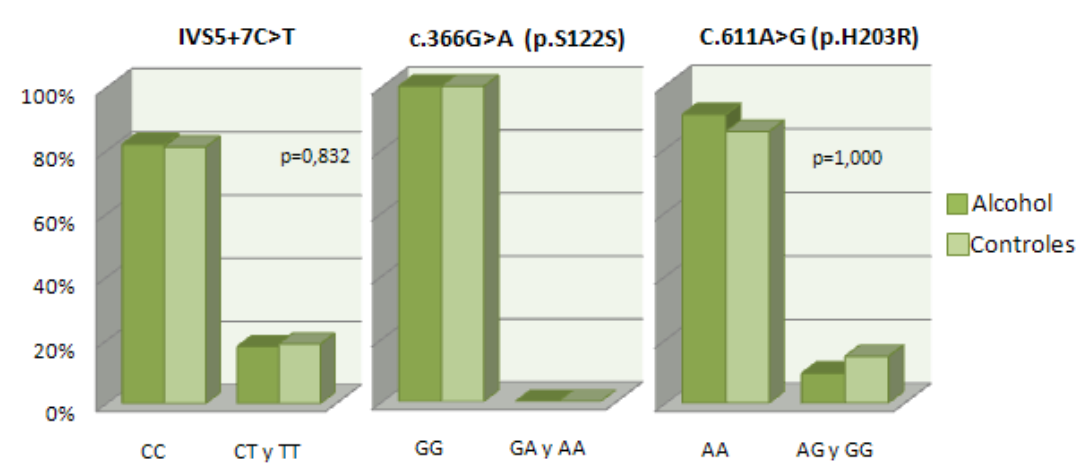

Figura 29: Distribución de los genotipos de los polimorfismos IVS5+7C >T, c.366G>A (p.S122S) y c.611A>G (p.H203R) entre individuos alcohólicos e individuos abstemios utilizados como controles. (A) Tabla en la que se representan los porcentajes de los genotipos para los tres polimorfismos. (B) Análisis estadístico de la distribución de las agrupaciones de genotipos de los tres polimorfismos estudiados. El valor de $p$ se hayó utilizando el test de Chi-cuadrado de Pearson. No se pudo realizar el análisis estadístico sobre los datos del polimorfismo c.366G>A (p.S122S) ante la ausencia de alelos $A$.

Dentro de los individuos adictos al alcohol diferenciamos dos subgrupos: los alcohólicos abusadores y los dependientes, como puede observarse en la figura 30A. Los subgrupos de alcohólicos fueron comparados entre sí a fin de observar si alguno de los polimorfismos estaba relacionado con el tipo de dependencia desarrollada por los distintos individuos consumidores habituales de alcohol. Esta comparación tampoco mostró diferencias (Fig. 30B). 


\begin{tabular}{|c|c|c|c|c|c|c|c|c|}
\hline \multirow{2}{*}{$A$} & & \multicolumn{3}{|c|}{ Distribución de los genotipos } & \multirow{2}{*}{ HWE } & \multicolumn{2}{|c|}{ Agrupación de genotipos } & \multirow{2}{*}{ Total } \\
\hline & & CC & CT & $\mathrm{TT}$ & & CC & СТ у TT & \\
\hline \multirow{3}{*}{ IVS5+7C>T } & $\mathrm{Ab}$ & $81(8$ & 17 & $1(1$ & 18 & $81(81,8$ & $18(18,2 \%$ & $99(100 \%)$ \\
\hline & Depe & $146(82,5 \%)$ & $28(15,8 \%)$ & $3(1$ & 0,237 & $146(82$ & 31 & $177(100 \%)$ \\
\hline & & AA & 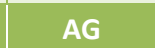 & co & HWE & AA & $A G$ & Tote \\
\hline \multirow{2}{*}{$\begin{array}{l}\text { c.611A>G } \\
\text { (p.H203R) }\end{array}$} & Abusador & $90(90,9 \%)$ & $9(9,1 \%)$ & $0(0 \%)$ & 0,636 & $90(90,9 \%)$ & $9(9,1 \%)$ & $99(100 \%)$ \\
\hline & Dependiente & $160(90,4 \%)$ & $17(9,6 \%)$ & $0(0 \%)$ & 0,502 & $160(90,4 \%)$ & $17(9,6 \%)$ & $177(100 \%)$ \\
\hline
\end{tabular}

B

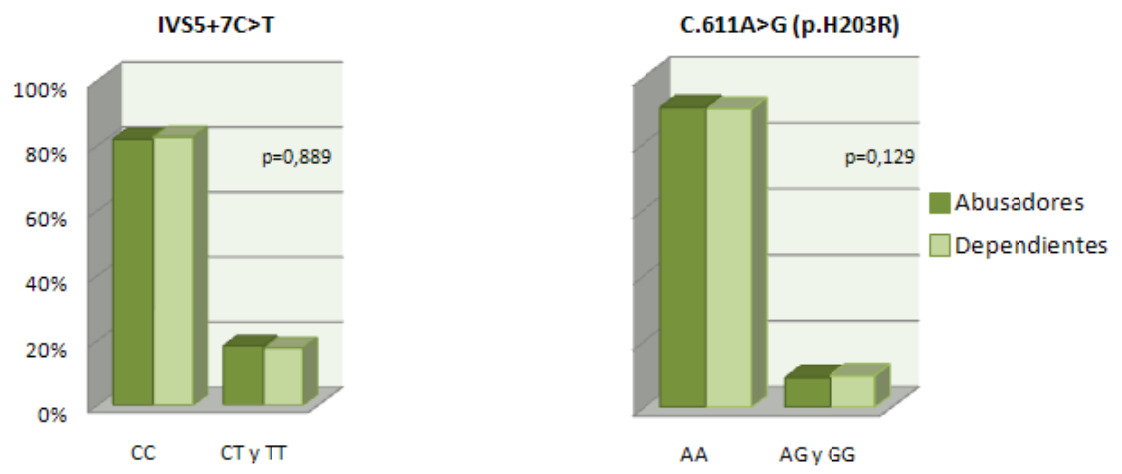

Figura 30: Distribución de los genotipos de los polimorfismos IVS5+7C>T y c.611A >G (p.H203R) entre individuos alcohólicos agrupados en abusadores y dependientes según el tipo de adicción que sufrieran. (A) Tabla en la que se representan los porcentajes de los genotipos para los polimorfismos IVS5+7C>T y c.611A>G (p.H203R). (B) Análisis estadístico de la distribución de las agrupaciones de genotipos de los dos polimorfismos estudiados entre los tipos de alcoholismo. El valor de $p$ se hayó utilizando el test de Chi-cuadrado de Pearson.

En conjunto, nuestros resultados revelan que las variantes polimórficas del gen CHN2 no muestran asociación con la predisposición al desarrollo de tumores, pero existe una clara asociación del polimorfismo c.366G>A (p.S122S) con la adicción.

\section{ANÁLISIS TRANSCRIPCIONAL Y FUNCIONAL DEL GEN CHN2.}

\section{II.1. ANÁLISIS DE LA EXPRESIÓN DEL GEN CHN2.}

Los resultados del apartado anterior muestran que no existen o son muy poco frecuentes mutaciones patogénicas en el gen CHN2 asociadas a los tipos de cáncer estudiados. Por tanto, decidimos analizar otras posibles alteraciones del gen CHN2 que pudieran asociarse con estas enfermedades. La única alteración descrita hasta el momento de $\beta 2$-quimerina asociada con el cáncer es la disminución de su expresión, 
observada en un número limitado de cáncer de mama y glioblastomas. Para profundizar en este aspecto, decidimos realizar, en primer lugar, un análisis de la expresión del gen CHN2 en distintas líneas celulares tumorales de diferente procedencia. Seleccionamos una batería de líneas celulares de cáncer de mama, sistema nervioso central, páncreas y próstata, y otras derivadas de leucemias y linfomas. Como controles utilizamos sangre periférica de un individuo sano y la línea celular MCF10A derivada de tejido mamario sano. Mediante PCR anidada analizamos en estas muestras los patrones de expresión de los dos tránscritos derivados del gen CHN2 (Fig. 31).

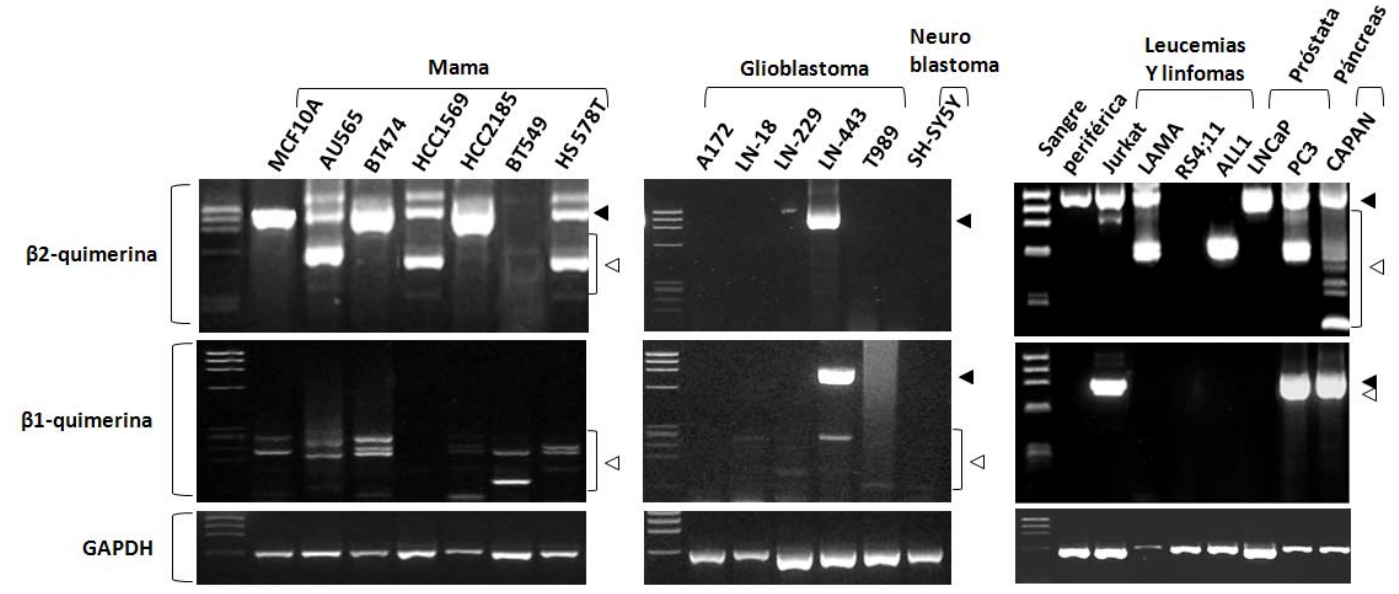

Figura 31: Análisis de la expresión de las quimerinas $\beta 2$ y $\beta 1$ en líneas celulares tumorales por PCR anidada. En los paneles superiores se muestra la expresión del tránscrito $\beta 2$-quimerina. En los paneles centrales se muestra la expresión del tránscrito $\beta 1$-quimerina. En los paneles inferiores se muestra la amplificación de GAPDH utilizada como control de la muestra. La flecha negra indica la banda correspondiente a los tránscritos completos $\beta 2$ - y $\beta 1$-quimerina. La flecha blanca señala lo productos de PCR de menor tamaño encontrados.

Acorde con lo descrito por otros autores, en este estudio observamos la ausencia de expresión de $\beta 2$-quimerina en líneas de cáncer de mama y glioblastomas. Esta ausencia de expresión también se observó en líneas tumorales de distintos tipos de leucemias (RS4;11: leucemia linfoblástica aguda y ALL-1: derivada de leucemia mieloide crónica). Los controles utilizados en el estudio sí mostraron expresión del tránscrito $\beta 2$ Aunque el número de líneas analizadas es limitado, nos ha permitido constatar una ausencia recurrente de este tránscrito en distintos tipos tumorales.

También analizamos la expresión de $\beta 1$-quimerina, isoforma de la que sólo se ha descrito su expresión en testículo de rata ${ }^{167}$. En este caso, se detecta tránscrito en líneas 
celulares de distinta procedencia: LN-443, Jurkat, PC3 y CAPAN. Por lo que podemos observar, parece que la expresión de $\beta 1$-quimerina no está reducida a testículo como se conocía hasta el momento.

Inesperadamente, observamos la aparición de productos de PCR de diferente tamaño a los esperados, tanto derivados de la isoforma $\beta 2$ - como de la $\beta 1$-quimerina, que parecen restringidos a las muestras tumorales. Estos productos podrían ser indicativos de la presencia de isoformas truncadas, un tipo de alteración también asociada con cáncer.

Ante estos datos obtenidos en este análisis preliminar, nos planteamos estudiar tanto el mecanismo que puede conducir al silenciamiento del gen, como la relevancia de los tránscritos encontrados.

\section{II.2. VARIANTES TRANSCRIPCIONALES DEL GEN CHN2.}

\section{II.2.a. Descripción de nuevas variantes del gen CHN2.}

Tras clonar y secuenciar los fragmentos de menor tamaño de las isoformas $\beta 2-y$ ß1-quimerina, identificamos un total de ocho nuevas variantes derivadas de la forma completa $\beta 2$-quimerina y nueve variantes derivadas de la $\beta 1$-quimerina. Todas se añadieron a la base de datos de NCBI (GenBank), asignándolas el número de secuencia que se indica en las tablas 16 y 17 . Este resultado revela que, además de las isoformas $\beta 2$ y $\beta 1-$, generadas por transcripción alternativa, a partir del gen $C H N 2$ se generan isoformas truncadas como resultado de splicing alternativo, un mecanismo hasta el momento no descrito para este gen.

\section{II.2.a.1 Variantes derivadas del preRNA mensajero de 62-quimerina.}

Las variantes derivadas de $\beta 2$-quimerina son, en su mayoría, RNAs de pequeño tamaño carentes de los nucleótidos que codifican los dominios fundamentales de la proteína (Fig. 32). A excepción de las variantes $\beta 2-\mathrm{CHNdel}$ ex3, $\beta 2-\mathrm{CHNdel}$ ex4-6 y $\beta 2$ CHNdel ex2-8,11-12, que pierden secuencias exónicas completas, las otras cinco isoformas truncadas presentan secuencias intraexónicas no canónicas de reconocimiento de la maquinaria de splicing en la secuencia donadora y/o la receptora (Tabla 14). 
Tabla 14: Secuencias de procesamiento intraexónico de las variantes derivadas del tránscrito $\beta 2$-quimerina que presentan pérdidas parciales de exones. En gris, nucleótidos del intrón; en negro, secuencia exónica.

\begin{tabular}{|c|c|c|}
\hline Variante de splicing & $\begin{array}{c}\text { Secuencia de procesamiento } \\
\text { intraexónico en } 5^{\prime}\end{array}$ & $\begin{array}{c}\text { Secuencia de procesamiento } \\
\text { intraexónico en } 3^{\prime}\end{array}$ \\
\hline$\beta 2-C H N d e l$ ex7p-13pB & AGAAGACACA & GCCCCCTGAG \\
\hline B2-CHNdel ex6-11p & & ATTTATAGAT \\
\hline$\beta 2-C H N d e l$ ex6p-12pB & ACTTTGTGGG & CTGCCCACTA \\
\hline$\beta 2-C H N d e l$ ex4p-12pC & TGGAAGAGAG & CCACTATGAA \\
\hline B2-CHNdel ex3p-12pA & CCTCGGGAGG & GATCCACCTC \\
\hline
\end{tabular}

Las únicas que mantienen dominios funcionales son la variante $\beta 2-\mathrm{CHNdel}$ ex4-6, que conserva los dominios SH2 y GAP, y la variante $\beta 2-\mathrm{CHNdel}$ ex7p-13pB, que conserva el dominio SH2. El resto de las isoformas truncadas pierden los tres dominios funcionales ya sea por la aparición de un codón de parada prematuro, como es el caso de $\beta 2$-CHNdel ex3, o porque los se eliminan los exones que codifican esta información, como en la isoforma $\beta 2-\mathrm{CHNdel}$ ex4p-12pC. En ocasiones, como en la variante $\beta 2-\mathrm{CHNdel}$ ex3p-12pA, se producen ambos procesos: la deleción de exones que codifican parte de los dominios funcionales y la pérdida de la fase de lectura.

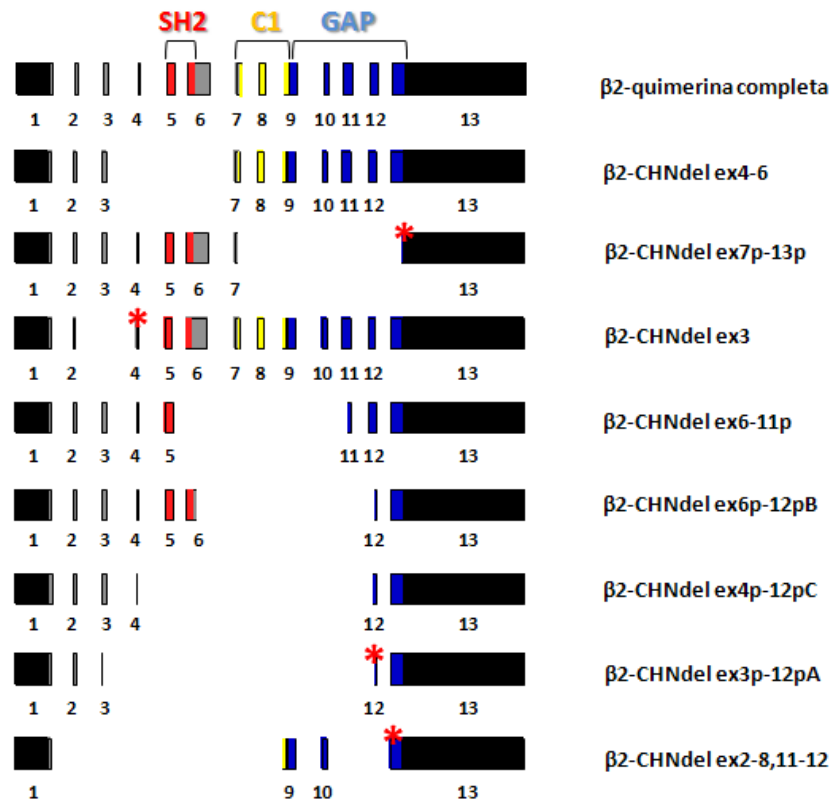

Figura 32: Representación gráfica de las variantes transcripcionales derivadas del preRNA de la 及2-quimerina, comparándolo con la estructura de la forma completa. El asterisco indica la aparición de un codón de parada prematuro. En rojo, aparece representada la secuencia que codifica el dominio funcional $\mathrm{SH}$, en amarillo, el dominio $\mathrm{C} 1$ y en azul, la secuencia que codifica el dominio GAP. 
En la tabla 15 resumimos las características de las variantes identificadas en cuanto a la pérdida de exones como resultado del splicing y las características de tamaño y conservación de dominios de los productos proteicos derivados.

Tabla 15: Resúmen de las características de las nuevas variantes identificadas derivadas del procesamiento alternativo del preRNA de $\beta 2$-quimerina.

\begin{tabular}{|c|c|c|c|c|c|c|c|c|c|}
\hline \multirow{2}{*}{$\begin{array}{l}\text { Variante de } \\
\text { splicing }\end{array}$} & \multirow{2}{*}{$\begin{array}{l}\text { Número } \\
\text { GenBank }\end{array}$} & \multirow[b]{2}{*}{ Pérdida exones } & \multirow{2}{*}{$\begin{array}{l}\text { Tamaño del } \\
\text { tránscrito }\end{array}$} & \multirow{2}{*}{$\begin{array}{l}\text { Fase de } \\
\text { lectura }\end{array}$} & \multicolumn{2}{|c|}{ Proteína } & \multicolumn{3}{|c|}{ Dominios } \\
\hline & & & & & $\begin{array}{c}\text { Tamaño } \\
\text { (aa) }\end{array}$ & $\begin{array}{l}\text { Peso } \\
\text { (kDa) }\end{array}$ & $\mathrm{SH} 2$ & C1 & GAP \\
\hline $\begin{array}{l}\text { B2-CHNdel } \\
\text { ex4-6 }\end{array}$ & EU732762 & 4 al 6 completos & $975 \mathrm{pb}$ & Conservada & 324 & 37,2 & No & Sí & Sí \\
\hline $\begin{array}{l}\text { B2-CHNdel } \\
\text { ex7p-13p }\end{array}$ & EU732766 & $\begin{array}{l}7 \text { parcial (18 pb) } \\
8 \text { al } 12 \text { completos } \\
13 \text { parcial }(83 p b)\end{array}$ & $725 \mathrm{pb}$ & Perdida & 216 & 24,9 & Sí & No & No \\
\hline $\begin{array}{l}\text { B2-CHNdel } \\
\text { ex3 }\end{array}$ & EU732760 & 3 completo & $1351 \mathrm{pb}$ & Perdida & 51 & 5,48 & No & No & No \\
\hline $\begin{array}{l}\text { B2-CHNdel } \\
\text { ex6-11p }\end{array}$ & EU732764 & $\begin{array}{l}7 \text { al } 10 \text { completos } \\
11 \text { parcial }(127 p b)\end{array}$ & $579 \mathrm{pb}$ & Conservada & 192 & 22 & No & No & No \\
\hline $\begin{array}{l}\text { 62-CHNdel } \\
\text { ex4p-12pC }\end{array}$ & EU732763 & $\begin{array}{c}4 \text { parcial (7 pb) } \\
5 \text { al } 11 \text { completos } \\
12 \text { parcial }(72 \mathrm{pb})\end{array}$ & $375 \mathrm{pb}$ & Conservada & 124 & 14,4 & No & No & No \\
\hline $\begin{array}{l}\text { 62-CHNdel } \\
\text { ex6p-12pB }\end{array}$ & EU732765 & $\begin{array}{l}6 \text { parcial ( } 237 \mathrm{pb}) \\
7 \text { al } 11 \text { completos } \\
12 \text { parcial ( } 68 \mathrm{pb})\end{array}$ & $549 \mathrm{pb}$ & Conservada & 182 & 21,1 & No & No & No \\
\hline $\begin{array}{l}\text { 62-CHNdel } \\
\text { ex3p-12pA }\end{array}$ & EU732761 & $\begin{array}{c}3 \text { parcial }(7 \mathrm{pb}) \\
4 \text { al } 11 \text { completos } \\
12 \text { parcial }(99 \mathrm{pb})\end{array}$ & $316 \mathrm{pb}$ & Perdida & 52 & 5,87 & No & No & No \\
\hline $\begin{array}{l}\text { 62-CHNdel } \\
\text { ex2-8, 11-12 }\end{array}$ & EU732759 & $\begin{array}{c}2 \text { al } 8,11 \text { y } 12 \\
\text { completos }\end{array}$ & $473 \mathrm{pb}$ & $\begin{array}{c}\text { Perdida } \\
\text { (2o splicing) }\end{array}$ & 103 & 11,3 & No & No & No \\
\hline
\end{tabular}

II.2.a.2 Variantes derivadas del preRNA mensajero de 81-quimerina.

En este trabajo, describimos nueve isoformas truncadas derivadas del pre-mRNA de $\beta 1$-quimerina (Fig. 33). En todas ellas la maquinaria de splicing reconoce secuencias de procesamiento canónico. De manera general se eliminan exones completos, aunque cuatro de las nueve variantes presentan deleción parcial del exón 7. Esta eliminación se produce en un sitio críptico de procesamiento a 135 pares de bases del final del exón, que cumple las características de una secuencia canónica de reconocimiento de la maquinaria de splicing (Tabla 16). A pesar de las deleciones, sólo tres isoformas truncadas pierden la fase de lectura generando un codón de parada prematuro en el exón 13. 
Tabla 16: Secuencia de procesamiento intraexónico de las variantes derivadas del tránscrito $\beta 1$-quimerina que presentan pérdida parcial del exón 7. En gris, nucleótidos del intrón; en negro, secuencia exónica.

\begin{tabular}{|l|c|}
\hline \multicolumn{1}{|c|}{ Variantes de splicing } & Secuencia de procesamiento intraexónico en 5' \\
\hline $\boldsymbol{\beta 1 - C H N d e l ~ e x 7 p}$ & AGGTGGGTGT \\
\hline $\boldsymbol{\beta 1 - C H N d e l ~ e x 7 p , 1 1}$ & $\mathbf{A G G T G G G T G T}$ \\
\hline $\boldsymbol{\beta 1 - C H N d e l ~ e x 7 p - 9}$ & $\mathbf{A G G T G G G T G T}$ \\
\hline $\boldsymbol{\beta 1 - C H N d e l ~ e x 7 p - 8 , 1 1 - 1 2}$ & AGGTGGGTGT \\
\hline
\end{tabular}

De las nueve variantes descritas, sólo $\beta 1-C H N d e l$ ex7p conserva intacto el dominio funcional GAP. Pierde 135 pares de bases del exón 7, lo que se traduce en la pérdida de 4 aminoácidos del dominio funcional $\mathrm{C} 1$, además de una parte de la proteína en el extremo N-terminal. Tres isoformas truncadas, $\beta 1-\mathrm{CHNdel}$ ex11, $\beta 1$-CHNdel ex10,11 y $\beta 1$-CHNdel ex11,12, conservan el dominio C1 pero pierden el dominio GAP por la eliminación de parte de la secuencia que lo codifica. El resto de las variantes transcripcionales pierden ambos dominios funcionales. A excepción de la variante $\beta 1$ CHNdel ex9, que pierde el exón 9, el cual codifica parcialmente tanto el dominio C1 como el GAP; el resto de las cuatro variantes sufren dos procesos de splicing alternativo consecutivos.

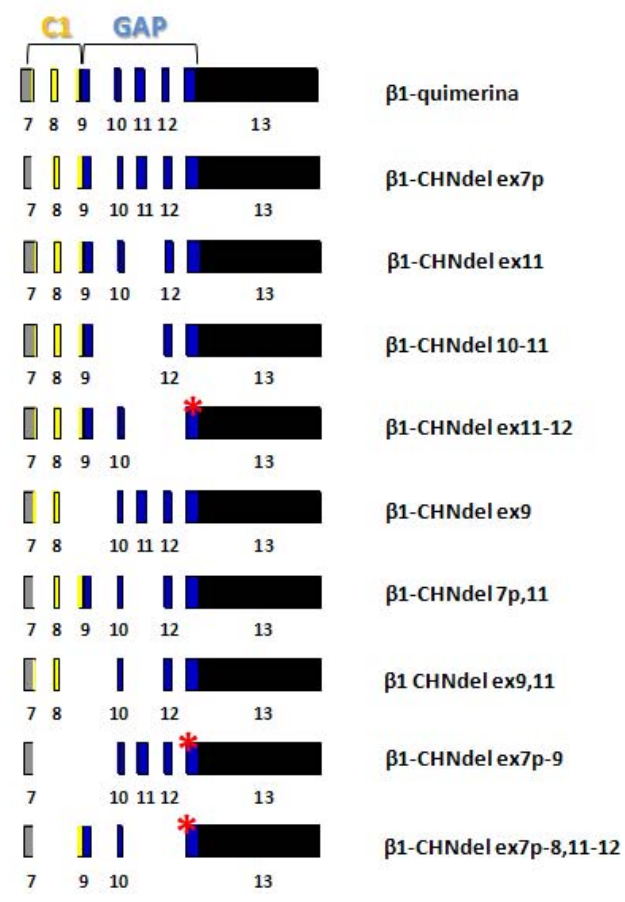

Figura 33: Representación gráfica de las variantes derivadas del pre-mRNA de la $\boldsymbol{\beta} 1$-quimerina, comparándolo con la estructura de la forma completa. El asterisco indica la aparición de un codón de parada prematuro. En amarillo aparece representada la secuencia que codifica el dominio funcional $\mathrm{C} 1$, y en azul, la secuencia que codifica el dominio GAP. 
En la tabla 17 indicamos los datos referentes a cada variante identificada: la pérdida de exones debida al splicing y las características de tamaño y conservación de dominios de las proteínas derivadas.

Tabla 17: Resumen de las características de las variantes identificadas derivadas del procesamiento alternativo del preRNA de $\beta 1$-quimerina.

\begin{tabular}{|c|c|c|c|c|c|c|c|c|}
\hline \multirow{2}{*}{$\begin{array}{c}\text { Variante de } \\
\text { splicing }\end{array}$} & \multirow{2}{*}{$\begin{array}{l}\text { Número } \\
\text { GenBank }\end{array}$} & \multirow[b]{2}{*}{ Pérdida exones } & \multirow[b]{2}{*}{$\begin{array}{l}\text { Tamaño del } \\
\text { tránscrito }\end{array}$} & \multirow[b]{2}{*}{$\begin{array}{l}\text { Fase de } \\
\text { lectura }\end{array}$} & \multicolumn{2}{|c|}{ Proteína generada } & \multicolumn{2}{|c|}{ Dominios } \\
\hline & & & & & $\begin{array}{c}\text { Tamaño } \\
\text { (aa) }\end{array}$ & \begin{tabular}{l|} 
Peso \\
(kDa)
\end{tabular} & C1 & GAP \\
\hline $\begin{array}{l}\text { 61-CHNdel } \\
\text { ex7p }\end{array}$ & EU732752 & 7 parcial $(135 \mathrm{pb})$ & $864 \mathrm{pb}$ & Conservada & 287 & 33 & $\begin{array}{c}\text { No } \\
(4 \mathrm{aa})\end{array}$ & Sí \\
\hline $\begin{array}{l}\text { 61-CHNdel } \\
\text { ex11 }\end{array}$ & EU732758 & 11 completo & $861 \mathrm{pb}$ & Conservada & 286 & 33,0 & Sí & No \\
\hline $\begin{array}{l}\text { 61-CHNdel } \\
\text { ex10, } 11\end{array}$ & EU732756 & 10 y 11 completos & $783 \mathrm{pb}$ & Conservada & 260 & 30,1 & Sí & No \\
\hline $\begin{array}{l}\text { B1-CHNdel } \\
\text { ex11, } 12\end{array}$ & EU732757 & 11 y 12 completos & $755 \mathrm{pb}$ & Perdida & 197 & 22,6 & Sí & No \\
\hline $\begin{array}{l}\text { 61-CHNdel } \\
\text { ex9 }\end{array}$ & EU732754 & 9 completo & $825 \mathrm{pb}$ & Conservada & 274 & 31,5 & No & No \\
\hline $\begin{array}{l}\text { 61-CHNdel } \\
\text { ex7p, } 11\end{array}$ & EU732753 & $\begin{array}{c}7 \text { parcial }(135 \mathrm{pb}) \\
11 \text { completo }\end{array}$ & $726 \mathrm{pb}$ & Conservada & 241 & 27,9 & $\begin{array}{c}\text { No } \\
(4 \mathrm{aa})\end{array}$ & No \\
\hline $\begin{array}{l}\text { B1-CHNdel } \\
\text { ex9, } 11\end{array}$ & EU732755 & 9 y 11 completos & $687 \mathrm{pb}$ & Conservada & 228 & 26,4 & No & No \\
\hline $\begin{array}{l}\text { 61-CHNdel } \\
\text { ex7p-9 }\end{array}$ & EU732751 & $\begin{array}{c}7 \text { parcial }(135 \mathrm{pb}) \\
9 \text { completo }\end{array}$ & $605 \mathrm{pb}$ & Perdida & 38 & 4,45 & No & No \\
\hline $\begin{array}{l}\text { B1-CHNdel } \\
\text { ex7p-8,11-12 }\end{array}$ & EU732750 & $\begin{array}{c}7 \text { parcial }(135 \mathrm{pb}) \\
8,11 \text { y } 12\end{array}$ & $535 \mathrm{pb}$ & Perdida & 40 & 4,65 & No & No \\
\hline
\end{tabular}

\section{II.2.b. Caracterización funcional de nuevas variantes del gen CHN2.}

Hemos seleccionado cuatro variantes del gen CHN2 para su caracterización funcional, junto con las formas completas $\beta 1$ - y $\beta 2$-quimerina. Seleccionamos las variantes $\beta 2-\mathrm{CHNdel}$ ex4-6 y $\beta 2-\mathrm{CHNdel}$ ex6p-12pB en representación de las isoformas truncadas derivadas de $\beta 2$-quimerina; y $\beta 1-C H N d e l$ ex7 $p$ y $\beta 1-C H N d e l$ ex $7 p, 11$, derivadas de $\beta 1$-quimerina. La variante $\beta 2$-CHNdel ex4-6 se incluyó porque pierde el dominio SH2, conservando los dominios C1 y GAP. Esta deleción la convierte en una variante muy similar a la isoforma completa $\beta 1$-quimerina. $\beta 2-C H N d e l$ ex6p-12pB representa a los tránscritos alternativos derivados de $\beta 2$-quimerina que muestran procesamiento no canónico y pierden la información de los dominios SH2, C1 y GAP. $\beta 1-C H N d e l$ ex7p pierde el dominio C1 por procesamiento de parte del exón 7, una deleción que ocurre en cuatro de las nueve isoformas truncadas derivadas de $\beta 1$-quimerina. La variante $\beta 1-\mathrm{CHNdel}$ 
ex7p,11 es característica de los tránscritos de $\beta 1$-quimerina que pierden ambos dominios funcionales, C1 y GAP.

Estudiamos dos aspectos fundamentales de la función de la proteína como reguladora negativa de la Rho GTPasa Rac: su localización subcelular y su actividad catalítica. Para este estudio clonamos las variantes transcripcionales en los vectores de expresión pCEFL-FLAG y pEGFP, y realizamos transfecciones transitorias en células COS-1. Comprobamos la correcta expresión de las construcciones de las distintas variantes en los vectores, por western blot. (Fig. 34)

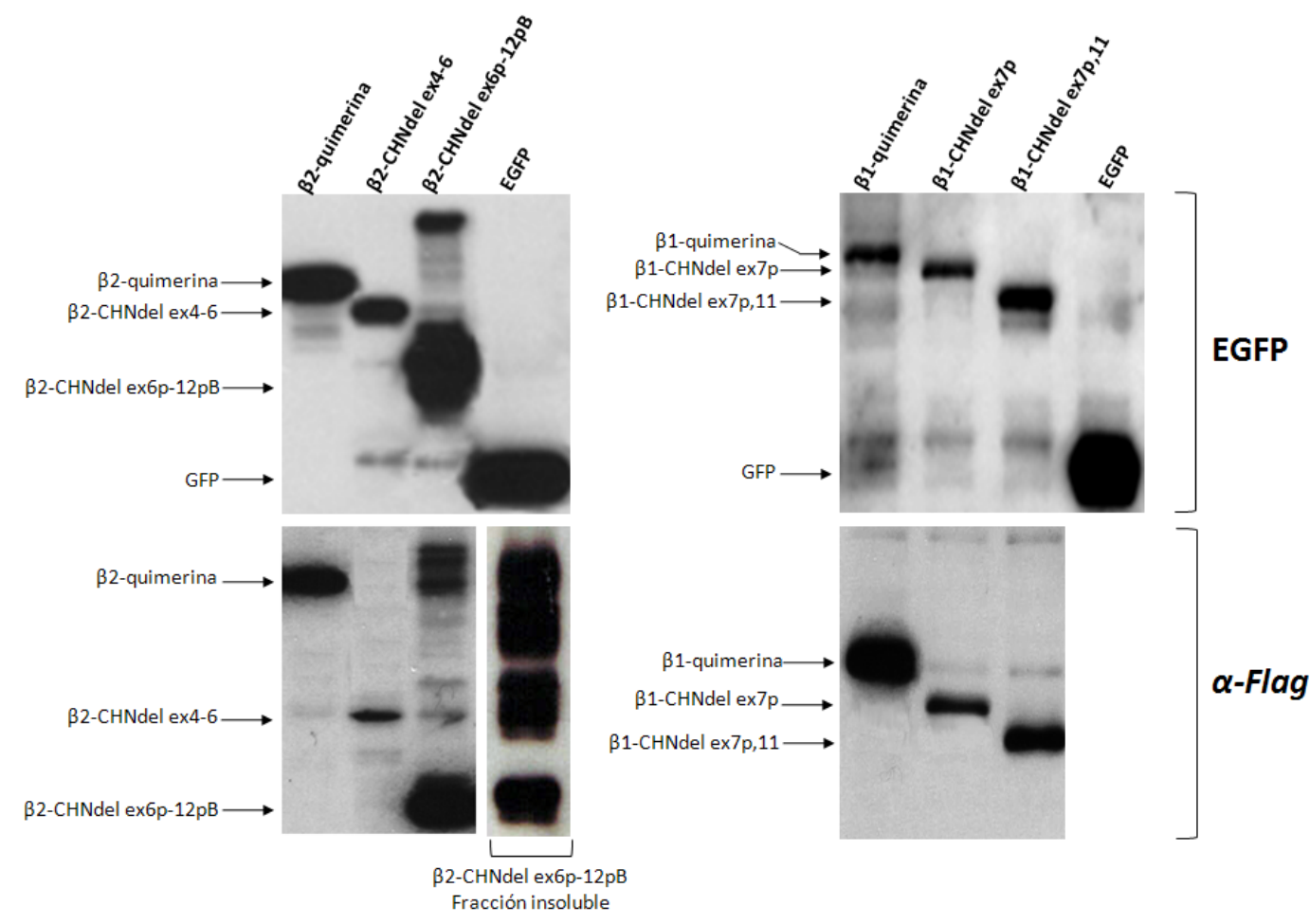

Figura 34: Western blot extractos proteicos obtenidos de células COS-1 transfectadas con las construcciones de las variantes de $\boldsymbol{\beta} 2$ - y $\boldsymbol{\beta} 2$-quimerina. La extracción realizó con tampón SPLB, excepto en el caso del cuarto carril del panel inferior izquierdo, que se trata de extractos proteicos de la fracción insoluble de células transfectadas con $\beta 2-C H N d e l$ ex6p-12pB.

En todos los casos observamos niveles de expresión elevados de las proteínas transfectadas, en los lisados totales obtenidos por lisis directa en tampón SPLB (Fig. 34). Los lisados de las células transfectadas con pCEFL-FLAG- $32-C H N d e l$ ex6p-12pB, se observó, además de la banda correspondiente a la proteína FLAG- $\beta 2-C H N d e l$ ex6p-12pB, unas bandas de mayor tamaño que no se observaba en los carriles correspondientes a las proteínas totales de las otras variantes. Estas bandas estaban enriquecidas en la fracción 
insoluble obtenidas con el tampón de lisis utilizado en los ensayos de pull-down ( $20 \mathrm{mM}$ Tris- $\mathrm{HCl} \mathrm{pH} \mathrm{7.4,} 150 \mathrm{mM} \mathrm{NaCl}, 5 \mathrm{mM} \mathrm{MgCl2}, 0.5 \% \mathrm{NP} 40,5 \mathrm{mM} \beta$-glicerofosfato, $1 \mathrm{mM}$ DTT). El patrón de bandas es muy similar a los patrones obtenidos en proteínas que se degradan por ubiquitinización.

II.2.b.1 Análisis de la localización subcelular de las variantes del gen CHN2.

La localización subcelular de las variantes del gen CHN2 se estudió por inmunofluorescencia, transfectando células COS-1 con las distintas variantes del gen fusionadas con GFP; 24 a 48 horas de crecimiento en fase exponencial, fueron analizadas mediante microscopía confocal (Fig. 35A).

En condiciones de crecimiento exponencial, la forma completa $\boldsymbol{\beta 2}$-quimerina mostró localización citoplasmática con mayor acúmulo en la zona perinuclear, patrón que ya se había descrito en trabajos previos ${ }^{86}$. La variante $\boldsymbol{\beta 2 - C H N d e l ~ e x 4 - 6 ~ m o s t r o ́ ~}$ localización citoplasmática pero con mayor presencia en la región perinuclear que $\beta 2$ quimerina, muy similar a la localización de la isoforma $\beta 1$-quimerina; resultado esperado puesto que ambas isoformas son estructuralmente muy similares. El caso de la variante ß2-CHNdel ex6p-12pB, la proteína presentó distintos patrones de localización dependiendo de la célula. En el $60 \%$ de los casos observamos presencia de la proteína en núcleo y citoplasma, frente al $40 \%$ de las células en las que la proteína se acumula formando agregados. La localización difusa se observó en las células con menor expresión, mientras que la localización en forma de agregados se observó en células con altos niveles de expresión de la proteína (Fig. 35C). No se observaron diferencias en la proporción de células con distinta localización respecto al tiempo post-transfección.

La isoforma completa $\beta 1$-quimerina se localizó en el citoplasma de la célula aunque con una mayor concentración en la región perinuclear que $\beta 2$-quimerina. Como se comentó anteriormente, esta isoforma tiene una localización muy similar a la isoforma ß2-CHNdel ex4-6. Sorprendentemente, la eliminación de parte del dominio C1 en las isoformas $\beta 1-C H N d e l$ ex7p y $\beta 1-C H N d e l$ ex7p,11 resulta en una localización nuclear de estas proteínas. Parte de la proteína $\beta 1-\mathrm{CHNdel}$ ex7p se observa en el citosol, pero esta localización es prácticamente nula en $\beta 1-C H N d e l$ ex7p,11. 
A

EGFP

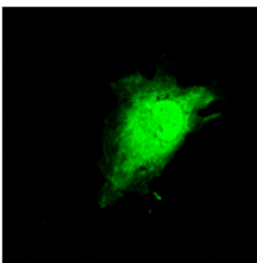

B2-quimerina

32-CHNdel ex4-6

B2-CHNdel ex6p-12pB
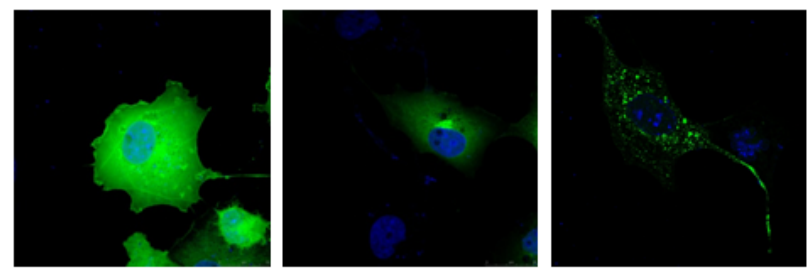

$\beta 1$-quimerina

ß1-CHNdel ex7p

B1-CHNdel ex7p,11

EGFP
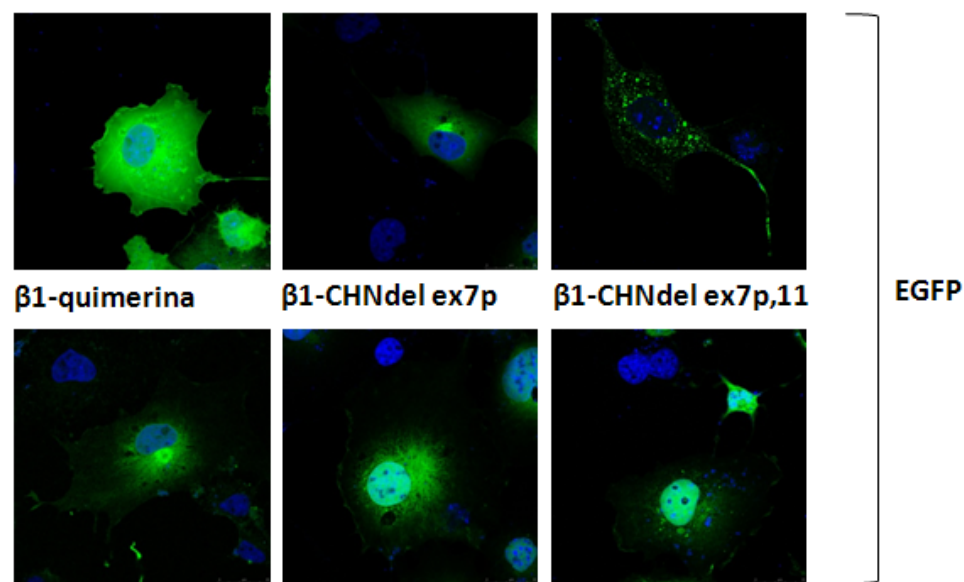

B

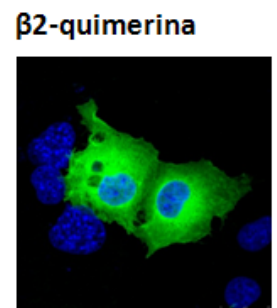

B2-CHNdel ex4-6

ß2-CHNdel ex6p-12pB

\section{B1-quimerina}
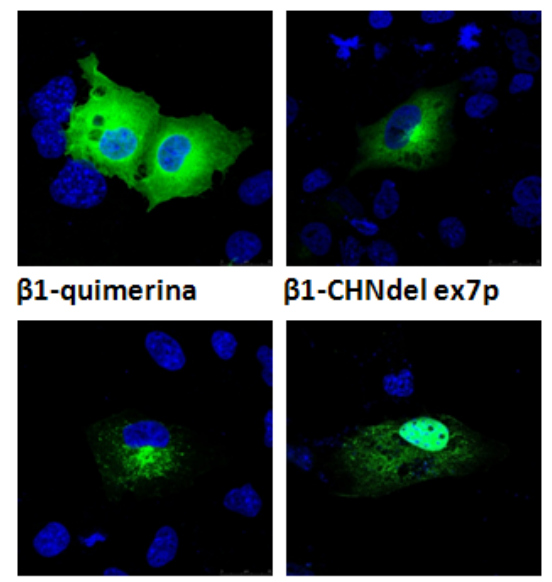

ß1-CHNdel ex7p

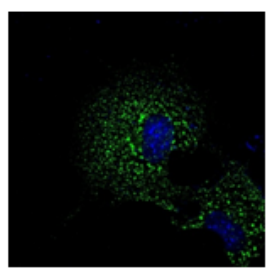

ß1-CHNdel ex7p,11

$\alpha-F L A G$
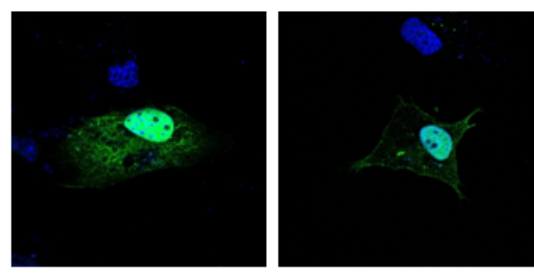

C
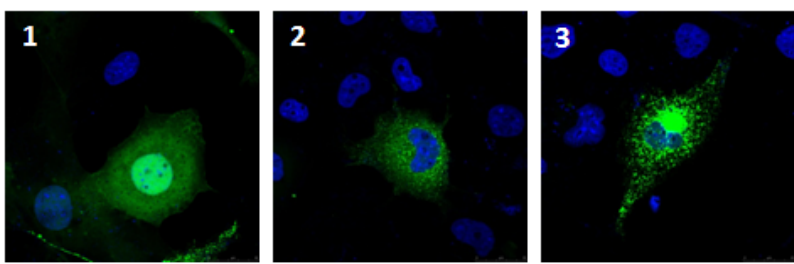

$\alpha-F L A G$

Figura 35: Localización subcelular de las variantes transcripcionales derivadas de $\beta 2$ - y $\beta 1$ quimerina y de las isoformas completas, células COS-1. (A) Localización subcelular de las proteínas fusionadas a GFP. (B) Localización subcelular de las proteínas etiquetadas con el epítopo FLAG. (C). Patrones de localización subcelular de la isoforma GFP- $\beta 2-C H N d e l$ ex6p-12pB representativas de los tres tipos de patrones de localización de esta proteína: 1) Citoplasma y núcleo. 2) Localización en agregados citoplasmáticos. 3) Agregados acumulados en la región perinuclear. Los núcleos se observan en azul, teñidos con DAPI. 
Para comprobar que la localización nuclear no se veía afectada por la fusión de la proteína GFP se realizó este experimento con las variantes fusionadas al epítopo FLAG, comprobando que se mantenía el mismo patrón de localización (Fig. 35B).

La regulación de la actividad de las quimerinas se realiza por el cambio en la localización subcelular o traslocación, producida por la generación de DAG tras la estimulación celular ${ }^{107}$ o por el tratamiento con PMA, análogo del DAG. Para comprobar cómo se veía afectada esta regulación en las isoformas truncadas, tratamos las células COS-1 transfectadas con PMA y analizamos la localización subcelular con microscopía confocal.

En la figura 36 se muestra la localización subcelular de la isoforma $\beta 2$-quimerina y

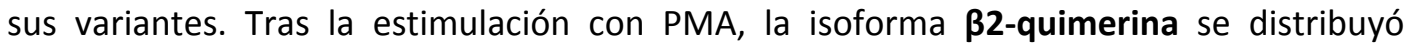
fundamentalmente a la región perinuclear, resultados similares a los descritos por otros autores. En las mismas condiciones, la proteína $\boldsymbol{\beta 2 - C H N d e l ~ e x 4 - 6 ~ s e ~ t r a s l o c o ́ ~ a ~ l a ~ r e g i o ́ n ~}$ perinuclear, observándose una acumulación de proteína alrededor de la membrana nuclear. Esta traslocación fue más efectiva que la observada para la forma completa $\beta 2$ quimerina y muy similar al que presenta la isoforma $\beta 1$-quimerina. En el caso de la variante $\boldsymbol{\beta 2}$-CHNdel ex6p-12pB la localización de la proteína no varió tras la estimulación con PMA, observándose el mismo patrón de localización de la proteína citoplasmática y en agregados observada en el control.
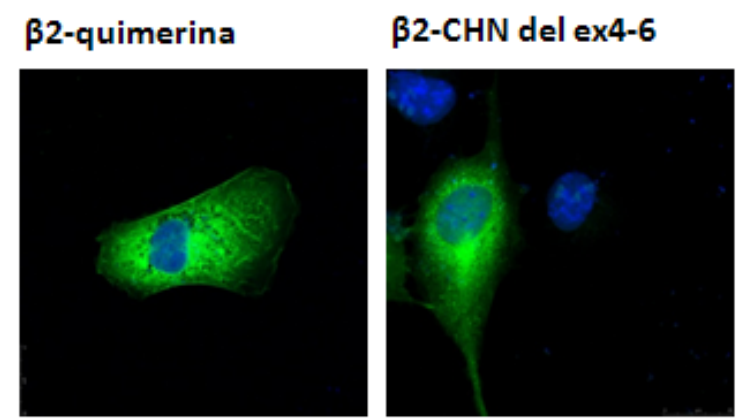

32-CHN del ex6p-12pB
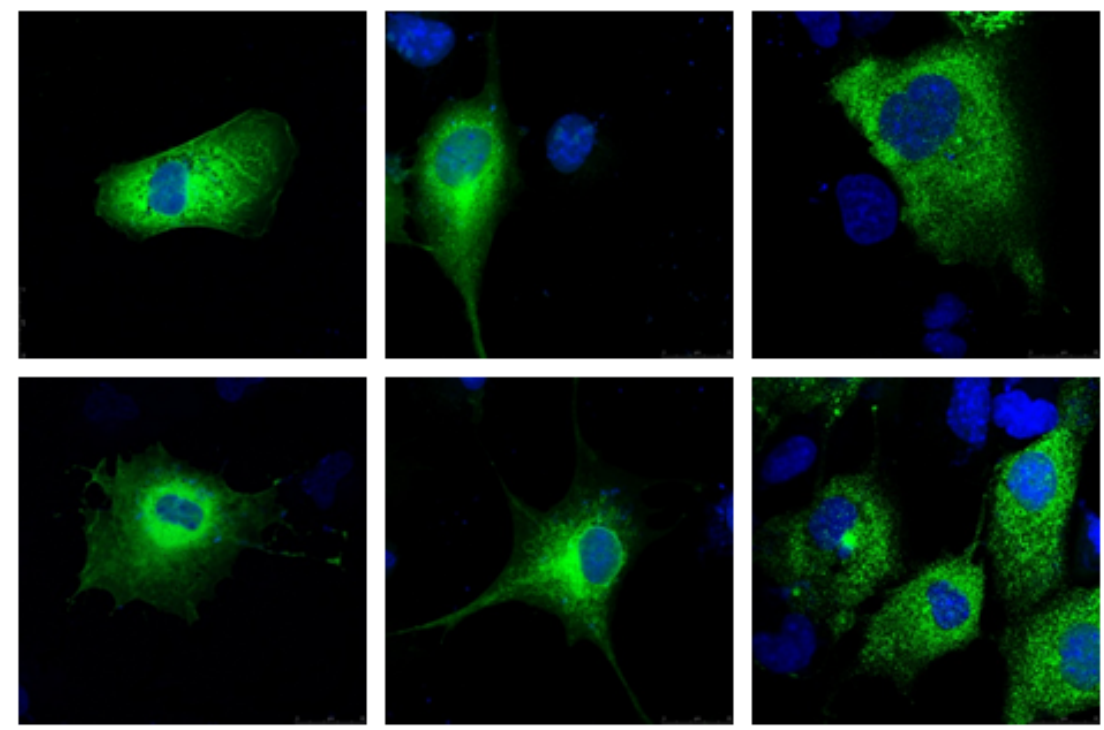

- PMA

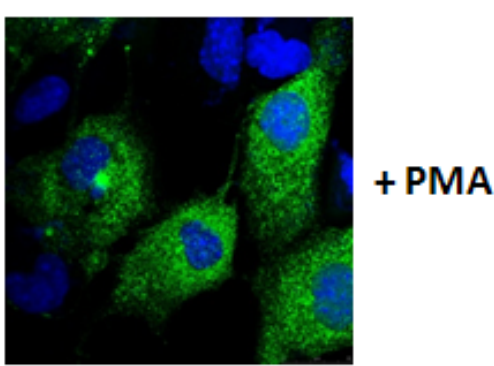

Figura 36: Localización subcelular de las variantes de la $\beta 2$-quimerina bajo tratamiento con PMA. Tras la transfección con las diferentes construcciones de variantes transcripcionales de B2-quimerina a estudio, las células se privaron de suero durante al menos 4 horas para ser tratadas, posteriormente, con PMA (+PMA) o mantener un control sin tratamiento (-PMA). 
Los resultados obtenidos en células transfectadas con $\beta 1$-quimerina y sus isoformas truncadas derivadas se muestran en la figura 37. $\boldsymbol{\beta} 1$-quimerina, tras la estimulación con PMA, se acumuló en la región perinuclear. Esta traslocación fue más eficaz que la de la $\beta 2$-quimerina y similar a la que se observó con la variante $\beta 2$-CHNdel ex4-6. Las variantes $\boldsymbol{\beta} 1-\mathrm{CHNdel}$ ex7p y $\boldsymbol{\beta} 1-\mathrm{CHNdel}$ ex7p,11 mantuvieron su localización, no respondiendo al tratamiento con PMA.

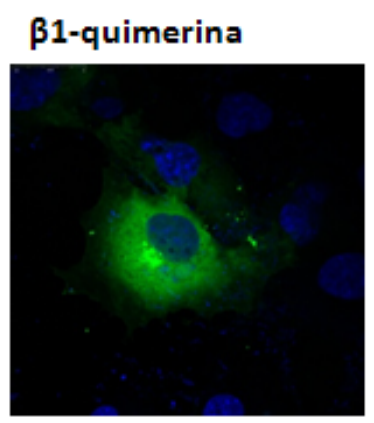

\section{$\beta 1-\mathrm{CHN}$ del ex7p}

$\beta 1-\mathrm{CHN}$ del ex7p,11
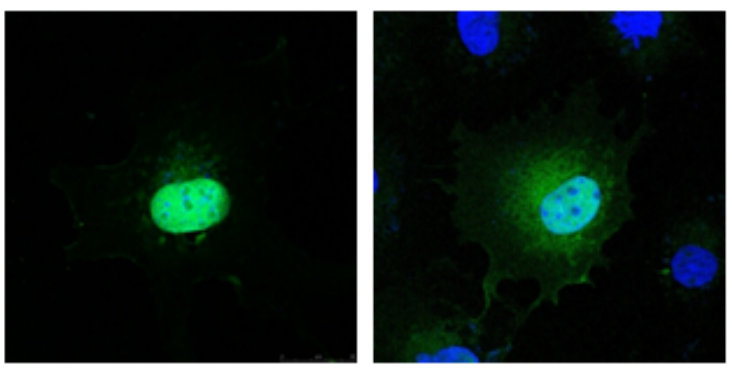

- PMA
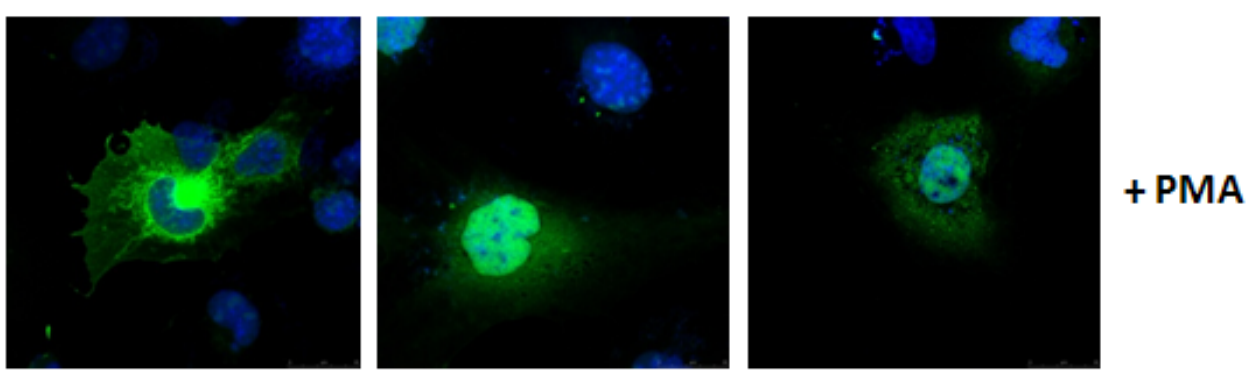

Figura 37: Localización subcelular de las variantes de la $\beta 1$-quimerina bajo tratamiento con PMA. Tras la transfección con las diferentes construcciones de variantes transcripcionales de B1-quimerina a estudio, las células se privaron de suero durante al menos 4 horas para ser tratadas, posteriormente, con PMA (+PMA) o mantener un control sin tratamiento (-PMA).

II.2.b.2 Análisis de la actividad GAP de las variantes del gen CHN2.

Para evaluar cómo la modificación de las isoformas truncadas en sus dominios funcionales afecta a la actividad catalítica, se estudió su actividad GAP en comparación con la actividad de las isoformas completas $\beta 1$ - y $\beta 2$-quimerina. Para este estudio realizamos un ensayo de pull-down en células COS-1 transfectadas con las distintas construcciones. 
A

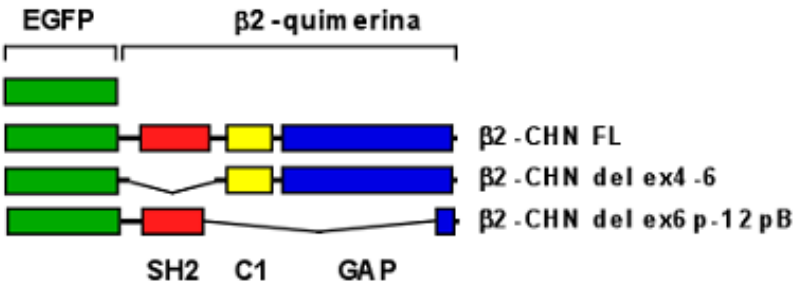

B
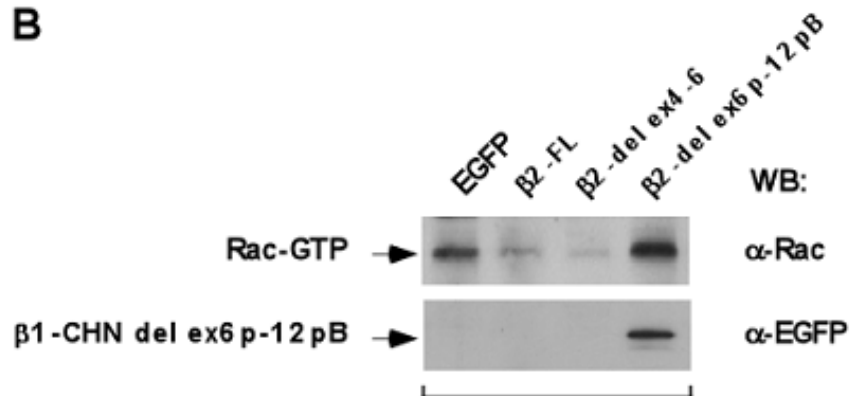

GST Pull-down

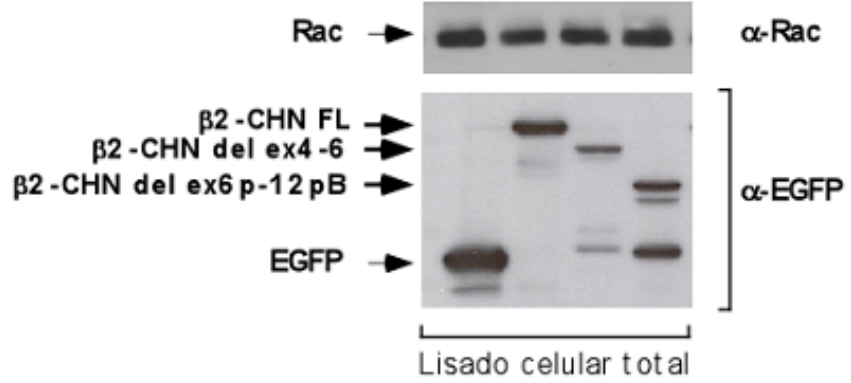

C

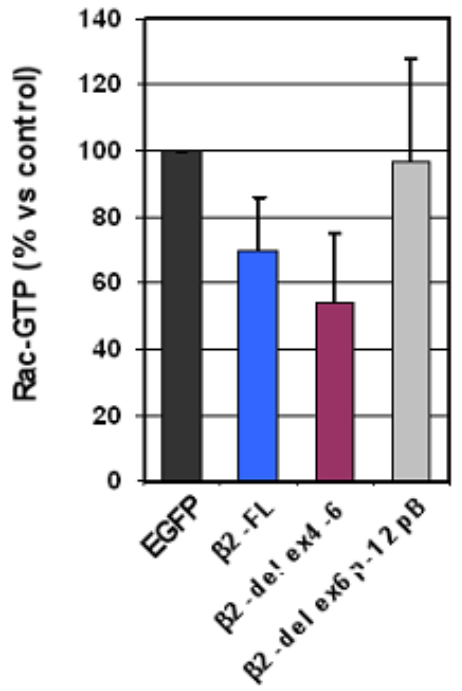

Figura 38: Ensayo de pull-down de la isoforma $\beta 2$-quimerina y sus variantes. (A) Esquema de las construcciones sobreexpresadas en células COS-1. (B) Western-blot de las muestras de pull-down y lisados celulares totales, incubadas con anticuerpos anti-GFP y anti-Rac. (C) Densitometría de cantidad de Rac-GTP (B, 1er panel) respecto a la cantidad total de Rac (B, 3er panel), para cada una de las muestras (3 experimentos). La muestra transfectada con el plásmido pEGFP vacio se utilizó como control del ensayo. (FL: Full lenght). 
En la figura 38 se mostraron los resultados obtenidos en los estudios de determinación de la actividad de Rac en células transfectadas con las distintas variantes derivadas de $\beta 2$-quimerina. Al comparar los niveles de Rac-GTP endógenos de las células COS-1 transfectadas con las distintas variantes de $\beta 2$-quimerina, observamos que la transfección de la isoforma completa inducía una disminución de los niveles de Rac-GTP del 30\% respecto a la muestra control (Fig. 38B y C). Esta disminución de la activación de Rac se debe a la actividad GAP propia de la proteína $\beta 2$-quimerina, y ya había sido observada en estudios previos ${ }^{111}$. La sobreexpresión de la variante $\beta 2-\mathrm{CHNdel}$ ex4-6 produjo una disminución en los niveles de Rac-GTP más marcada (50\%) que la causada por la sobreexpresión de la isoforma $\beta 2$-quimerina (Fig. 38B y C). Este hecho sugiere que la variante $32-\mathrm{CHNdel}$ ex4-6 presenta una mayor actividad GAP que la isoforma completa ß2-quimerina en condiciones de crecimiento exponencial. La sobreexpresión de la variante $\beta 2-\mathrm{CHNdel}$ ex6p-12pB no modificó los niveles de Rac-GTP respecto al control (Fig. 38B y C).

Los niveles de Rac total fueron similares en todas las muestras estudiadas (Fig. 38B. Tercer panel). Los niveles de sobreexpresión de las distintas variantes estudiadas se expresaron al mismo nivel, excepto la isoforma truncada $\beta 2$-CHNdel ex4-6, que se expresó a un nivel más bajo (Fig. 38B. Panel inferior).

Los resultados de las variantes derivadas de $\beta 1$-quimerina se muestran en la figura 39. La sobreexpresión de la isoforma completa se traduce en una disminución de los niveles de Rac-GTP del $40 \%$ respecto a la muestra control (Fig. 39B y C). Esta disminución de Rac activo es mayor que la disminución causada por la sobreexpresión de la isoforma $\beta 2$-quimerina. Estos datos son similares a los publicados por otros grupos y se explica porque la estructura de esta isoforma está menos autoinhibida. La sobreexpresión de la variante $\beta 1$-CHNdel ex7p redujo los niveles de Rac-GTP un $20 \%$ más que la isoforma ß1-quimerina (Fig. 39B y C). Ambas proteínas solo difieren en 45 aminoácidos en el extremo N-terminal lo que provoca la interrupción del dominio C1. La sobreexpresión de ß1-CHNdel ex7p,11 produjo una ligera disminución (25\%) de los niveles de Rac-GTP de la célula (Fig. 39C), a pesar de que no tienen un dominio GAP funcional (Fig. 39A). 
A

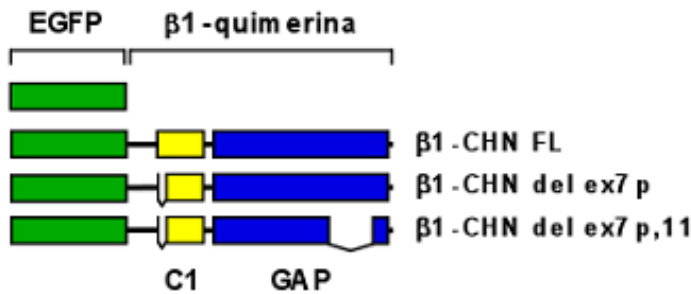

B
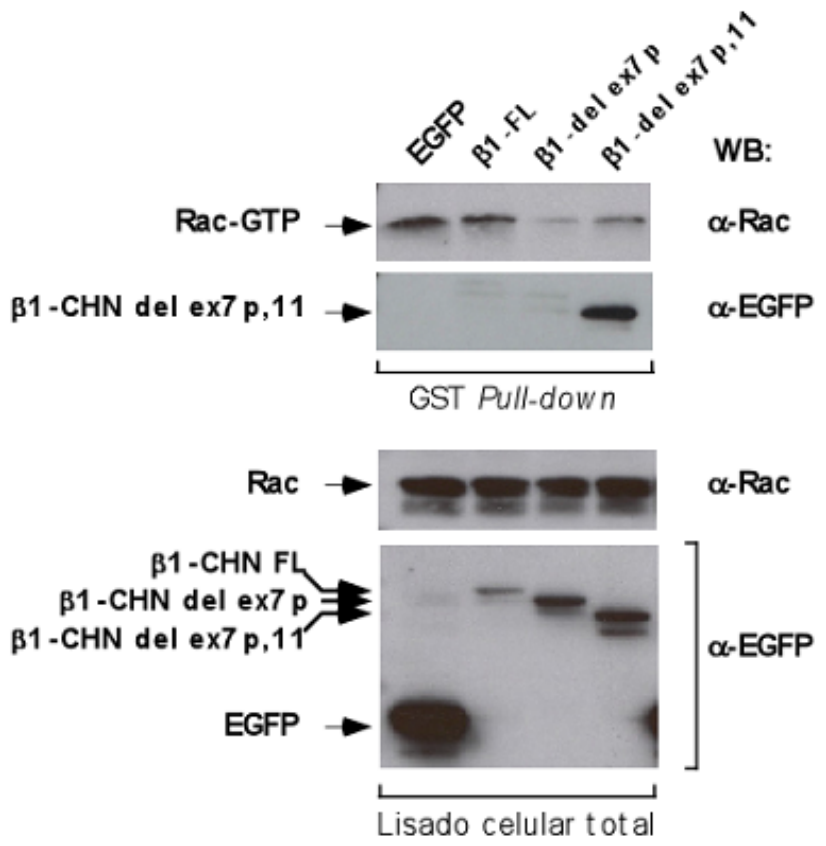

C

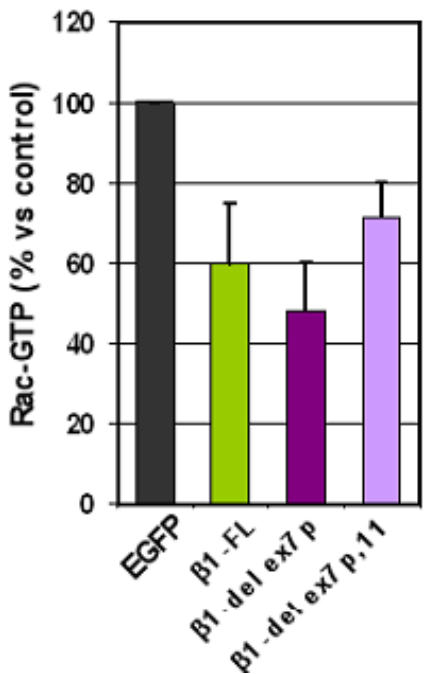

Figura 39: Ensayo de pull-down de la isoforma $\beta 1$-quimerina y sus variantes. (A) Esquema de las construcciones sobreexpresadas en células COS-1, para el experimento. (B) Western-blot de las muestras de pull-down y lisados celulares totales, incubadas con anticuerpos anti-GFP y anti-Rac. (C) Densitometría de cantidad de Rac-GTP (B, 1er panel) respecto a la cantidad total de $\operatorname{Rac}(B$, 3er panel), para cada una de las muestras (3 experimentos). La muestra transfectada con el plásmido pEGFP vacio se utilizó como control del ensayo. (FL: Full lenght). 
Los niveles de Rac total de las muestras fueron similares en todos los ensayos (Fig. 39B. Tercer panel). En cuanto a los niveles de sobreexpresión de las variantes de $\beta 1$ quimerina, todas se expresaron a niveles semejantes, a excepción de la isoforma completa ß1-quimerina, que alcanzó un nivel de expresión menor (Fig. 39B. Panel inferior).

En los experimentos de pull-down observamos que las variantes $\beta 2-\mathrm{CHNdel}$ ex6p12pB y $\beta 1-C H N d e l$ ex7p,11 coprecipitaban, en parte, con el complejo proteico Rac/RBD/GST/Glutatión (Fig. 38B y 39B. Segundo panel). Puesto que está descrito que las quimerinas se unen a Rac, y que esta unión es más estable en ausencia de actividad $\mathrm{GAP}^{107}$, es probable que estas isoforma se unan directamente a Rac. No obstante no se puede descartar que la coprecipitación se deba a la unión con otras proteínas participantes en este complejo.

\section{II.2.c. Estudio de expresión diferencial de los tránscritos del gen CHN2.}

Los experimentos realizados en el apartado anterior sirvieron para identificar variantes transcripcionales, pero no permitieron cuantificar los niveles de expresión del gen CHN2. Por tanto, decidimos cuantificar los niveles de expresión de los tránscritos del gen CHN2 por PCR cuantitativa. De todos los tránscritos identificados, decidimos comparar la expresión de:

- B2-quimerina. Es el tránscrito mayoritario en todas las muestras estudiadas, se expresa en una amplia variedad de tejidos y tipos celulares, y sus niveles de expresión ya habían sido estudiados previamente.

- $\quad$ B1-quimerina. En la literatura sólo está descrita su expresión en testículo de rata $^{108,111}$, pero decidimos estudiarlo ya que es la forma completa de la que derivan otras isoformas truncadas cuya expresión también fue estudiada.

- $\quad$ 32-CHNdel ex4-6. Es la única variante de $\beta 2$-quimerina que posee sitios de procesamiento canónicos, que conserva la fase de lectura y que mantiene los dominios funcionales C1 y GAP; además de haber sido detectada en varias líneas celulares distintas.

- $\quad \beta 1-C H N d e l$ ex7p. Isoforma truncada representativa de las cuatro variantes derivadas de $\beta 1$-quimerina, que pierden parte del exón 7. 
A

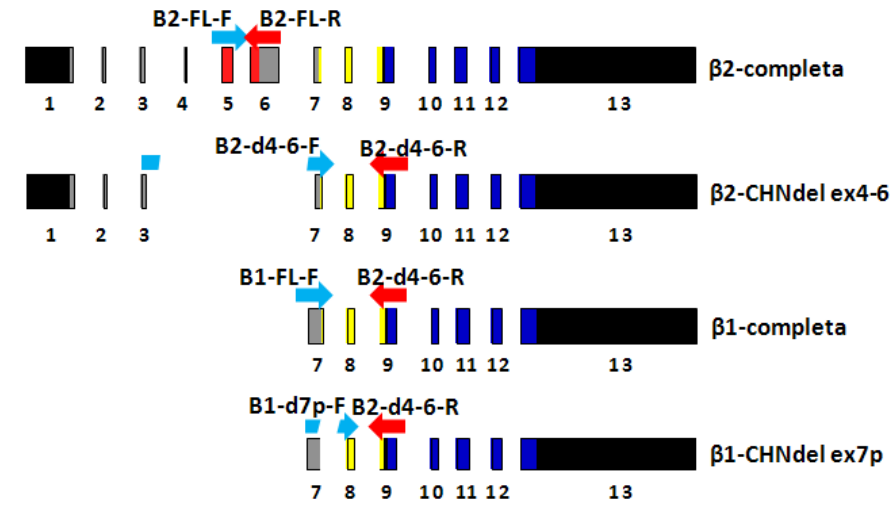

B

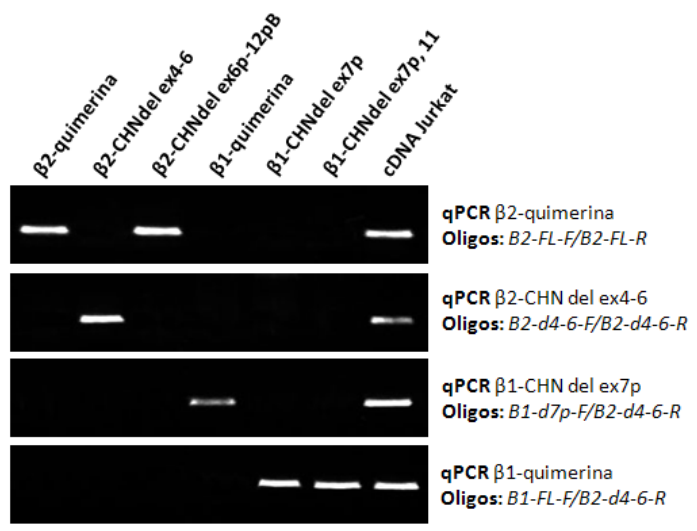

C

\begin{tabular}{|c|c|c|c|}
\hline$\beta 2-F L-F / \beta 2-F L-R$ & $\beta 2-d 4-6-F / \beta 2-d 4-6-R$ & $\beta 1-F L-F / \beta 2-d 4-6-R$ & $\beta 1-d 7 p-F / \beta 2-d 4-6-R$ \\
\hline B2-quimerina & B2-CHNdel ex4-6 & B1-quimerina & $\beta 1-C H N d e l$ ex7p-8,11-12 \\
\hline$\beta 2-\mathrm{CHNdel}$ ex3 & & $\beta 1-C H N d e l$ ex10, 11 & $\beta 1-\mathrm{CHNdel}$ ex7p \\
\hline$\beta 2-C H N d e l$ ex6p-12pB & & ß1-CHNdel ex11, 12 & ß1-CHNdel ex7p, 11 \\
\hline$\beta 2-C H N d e l$ ex7p-13p & & $\beta 1-C H N d e l$ ex11 & \\
\hline
\end{tabular}

Figura 40: Diseño de los oligonucleótidos utilizados en la amplificación de PCR cuantitativa. (A) Zona de anillamiento de los oligonucleótidos específicos para las distintas isoformas derivadas del gen CHN2 estudiadas por PCR cuantitativa. (B) Electroforesis en gel de agarosa de los productos de PCR. La PCR se realizó utilizando como molde, construcciones en PCEFL-FLAG de las isoformas indicadas, asi como cDNA de la línea celular Jurkat. (C) Tabla de reconocimiento de tránscritos del gen CHN2 de cada par de oligonucleótidos utilizados en el ensayo de PCR cuantitativa.

Para poder discernir entre los diferentes tránscritos, diseñamos oligonucleótidos específicos (Fig. 40A) que amplificaban los fragmentos deseados de manera específica, utilizando como molde vectores de expresión con las distintas isoformas, truncadas y completas. Como se observa en la figura 40B, los oligonucleótidos sólo amplificaron la secuencia específica del tránscrito correspondiente al par de oligonucleótidos diseñado 
para tal efecto. Estos oligonucleótidos están diseñados para discriminar entre los cuatro tránscritos del gen CHN2 a estudio pero, a excepción del par de oligonucleótidos para la isoforma truncada $\beta 2-\mathrm{CHNdel}$ ex4-6, que son exclusivos de esta isoforma, el resto pueden amplificar más de un tránscrito diferente a la vez, como aparece resumido en la figura 40 C. Por ejemplo, el par de oligonucleótidos diseñados para amplificar $\beta 2$-quimerina puede amplificar a la vez el tránscrito $\beta 2$-CHNdel ex6p-12pB.

La PCR cuantitativa se realizó sobre cDNA sintetizado con random primers a partir de RNA extraído de las células en crecimiento exponencial. Se amplificaron cuatro tráncritos del gen $C H N 2$ y los tránscritos de dos genes reporteros, GAPDH y $T B P$, en paralelo. En la figura 41 se muestra un ejemplo de esta amplificación en una línea celular de cáncer de mama.

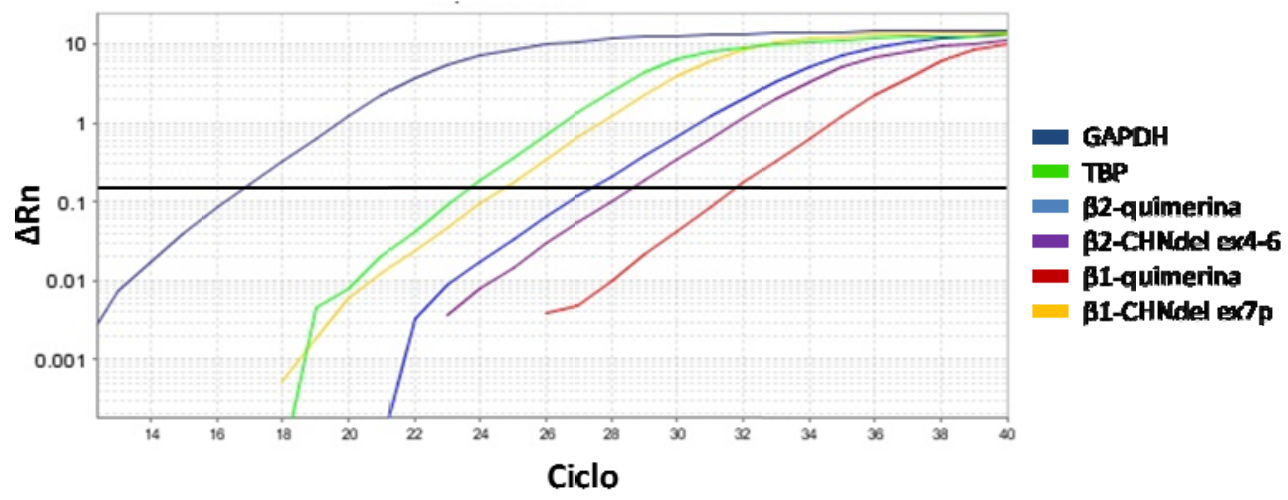

Figura 41: Gráfica de amplificación de PCR cuantitativa de una línea celular de cáncer de mama, para los distintos tránscritos amplificados. La gráfica está representada en escala logarítmica. El punto de corte de la línea horizontal con la curva de amplificación indica el valor Ct.

Los valores de $\Delta \mathrm{Ct}$ fueron hallados utilizando la media de los valores de $\mathrm{Ct}$ de cada muestra para los tránscritos de TBP y GAPDH como valores de referencia. El valor de $\Delta \Delta \mathrm{Ct}$ se halló restándole al valor de $\Delta \mathrm{Ct}$ de la muestra control, el valor $\Delta \mathrm{Ct}$ de cada muestra a estudio. El valor $\Delta \Delta C$ t expresa una diferencia de expresión en ciclos. Para que las diferencias se midan en proporción del número de tránscritos se calculó el valor de RQ $\left(R Q=2^{-\Delta \Delta C t}\right)$. 
II.2.c.1 Expresión diferencial de los tránscritos del gen CHN2 en líneas celulares de cáncer de mama.

Para determinar la expresión de las isoformas descritas en cáncer de mama, seleccionamos once líneas celulares representativas de los tres tipos celulares más comunes de cáncer de mama (luminal, basal A y basal B), y una línea celular derivada de células mamarias no tumorales inmortalizadas (MCF10A), utilizada como control.

El valor de $\Delta \Delta \mathrm{Ct}$ en el estudio refiere los valores de $\Delta \mathrm{Ct}$ de cada muestra a los niveles de expresión del tránscrito $\beta 2$-quimerina en la línea celular MCF10A, por tanto el valor de RQ de $\beta 2$-quimerina para MCF10A fue igual a 1 . A mayor valor de $R Q$, mayor expresión respecto a la expresión de MCF10A del tránscrito $\beta 2$-quimerina (Tabla 18).

Tabla 18: Valores de RQ para cada muestra de líneas celulares de mama y cada grupo de tránscritos del gen $C H N 2$, referidos a la expresión del tránscrito de $\beta 2$-quimerina para la línea celular MCF10A. (Valor de $\mathrm{RQ}=1$ ).

\begin{tabular}{|c|c|c|c|c|c|}
\hline & Línea celular & B2-quimerina & B2-CHNdel ex4-6 & $\beta 1$-quimerina & $\beta 1-C H N d e l$ ex7p \\
\hline \multirow{4}{*}{ Luminal } & AU565 & 2,110 & 0,003 & 0 & 0,023 \\
\hline & BT-474 & 0,436 & 0,024 & 0 & 0,297 \\
\hline & LY2 & 1,287 & 0,348 & 0 & 2,806 \\
\hline & MDA-MB-415 & 4,344 & 0,001 & 0 & 0,008 \\
\hline \multirow{4}{*}{ Basal A } & HCC1569 & 0,122 & 0 & 0 & 0,507 \\
\hline & HCC1937 & 3,233 & 0,005 & 0 & 0,260 \\
\hline & HCC2185 & 0,739 & 0,432 & 0 & 0,315 \\
\hline & MCF7 & 0,005 & 0 & 0 & 0 \\
\hline \multirow{4}{*}{ Basal B } & BT-549 & 0,028 & 0,001 & 0 & 0,026 \\
\hline & HS578T & 12,310 & 0,020 & 0 & 1,041 \\
\hline & HBL100 & 0,022 & 0,004 & 0 & 0,114 \\
\hline & MCF10A & 1 & 0,002 & 0 & 0,075 \\
\hline
\end{tabular}

La línea MCF10Aexpresa casi exclusivamente $\beta 2$-quimerina, ya que el tránscrito $\beta 1-\mathrm{CHNdel}$ ex7p se expresa a unos niveles muy bajos, y la expresión de $\beta 2-\mathrm{CHNdel}$ ex4-6 es imperceptible. En ninguna de las 12 líneas celulares estudiadas, los valores $\mathrm{Ct}$ del tránscrito $\beta 1$-quimerina fueron superiores al límite mínimo de detección de la técnica, por lo que se consideró que esta isoforma no se expresaba en estas muestras.

Comparando los valores de expresión de los distintos tránscritos con la muestra control MCF10A, observamos que, dentro de las líneas celulares de tipo luminal, el 
tránscrito $\beta 2$-quimerina se expresa a un nivel bastante alto. Excepto la línea BT-474, que presenta unos valores de expresión inferiores a la muestra control, las otras tres líneas celulares expresan este tránscrito entre 1 y 4 veces más que MCF10A. Las isoformas truncadas $\beta 2-\mathrm{CHNdel}$ ex4-6 y $\beta 1-\mathrm{CHNdel}$ ex7p presentan bajos niveles de expresión, apenas inapreciables en algunas ocasiones como en MDA-MB-415, a excepción de la variante $\beta 1-C H N d e l$ ex7p en la línea celular LY2, que se expresa a niveles incluso superiores que el tránscrito $\beta 2$-quimerina para esta muestra.

El grupo de líneas celulares de tipo Basal A presenta, de manera general, una expresión de todos los tránscritos por debajo del valor de $\beta 2$-quimerina para la muestra control, a excepción de la línea HCC1937. En esta línea, la forma completa ß2-quimerina se expresa 3 veces más que la línea control para ese tránscrito. La variante $\beta 2$-CHNdel ex4-6 sólo se expresa en la línea HCC2185. La expresión deß1-CHNdel ex7p es baja pero detectable en tres de las cuatro líneas Basal A. MCF7 no expresa ninguno de las variantes transcripcionales del gen $\mathrm{CHN} 2$ estudiadas.

Dentro del grupo de líneas celulares con características de Basal B, las líneas BT549 y HBL100 tienen expresión casi indetectable de los tránscritos $\beta 2$-quimerina y $\beta 2$ CHNdel ex4-6, y baja expresión del tránscrito $\beta 1-C H N d e l$ ex7p. La línea HS578T presenta unos niveles de $\beta 2$-quimerina hasta 12 veces mayores que los de la línea control, al igual que unos altos niveles de $\beta 1-\mathrm{CHNdel}$ ex7p, al menos al compararlos con la expresión de esta isoforma truncada en otras líneas celulares; sin embargo, los niveles de $\beta 2 \mathrm{CHNdel}$ ex4-6 son muy bajos.

1I.2.d. Expresión diferencial de los tránscritos del gen CHN2 en líneas celulares de tumores del sistema nervioso central.

Para analizar la relevancia de los tránscritos del gen CHN2 en tumores del sistema nervioso central, seleccionamos cuatro líneas celulares derivadas de glioblastomas multiformes y una línea celular derivada de neuroblastoma (SH-SY5Y). Esta línea se utilizó como referencia porque se ha descrito una disminución de la expresión de $\beta 2$-quimerina en glioblastomas multiformes y no en otros tipos de tumores del sistema nervioso central. El valor de $\Delta \mathrm{Ct}$ utilizado para la normalización es el valor correspondiente a la expresión de $\beta 2$-quimerina en esta línea. 
En las líneas celulares derivadas de tumores de sistema nervioso central no se detectó la expresión del tránscrito $\beta 1$-quimerina. Tampoco se detectó expresión de la variante $\beta 2-\mathrm{CHNdel}$ ex4-6, cuya expresión si era detectable, aunque a muy bajos niveles, en las líneas de mama. Se detectaron los tránscritos $\beta 2$-quimerina que, al igual que en las líneas celulares de mama, fue el tránscrito mayoritario, y la variante $\beta 1-C H N d e l$ ex7p (Tabla 19).

Tabla 19: Valores de RQ para cada muestra de líneas celulares de tumores del sistema nervioso central y cada grupo de tránscritos del gen $C H N 2$, referidos a la expresión del tránscrito de $\boldsymbol{\beta 2 - q u i m e r i n a ~ p a r a ~ l a ~ l i ́ n e a ~ c e l u l a r ~ S H - S Y 5 Y . ~ ( V a l o r ~ d e ~ R Q = 1 ) . ~}$

\begin{tabular}{|l|l|r|r|r|}
\hline \multicolumn{1}{|c|}{ Línea celular } & $\beta 2$-quimerina & $\beta 2$-CHNdel ex4-6 & $\beta 1$-quimerina & $\beta 1$-CHNdel ex7p \\
\hline A 172 & 1,047 & 0 & & 0,048 \\
\hline LN-18 & 0,076 & 0 & 0,000 & 0,001 \\
\hline LN-229 & 0,313 & 0 & 0,000 & 0,014 \\
\hline LN-443 & 5,255 & 0 & 0,019 & 1,110 \\
\hline T 989 & 0,456 & 0 & 0,001 & 0,101 \\
\hline SH-SY5Y & 1 & 0 & 0,001 & 0,030 \\
\hline
\end{tabular}

La línea control SH-SY5Y expresa la isoforma $\beta 2$-quimerina y, a niveles muy bajos, ß1-CHNdel ex7p (Tabla 19). Dentro de las líneas derivadas de glioblastomas, la línea A172, presentó un patrón de expresión similar a SH-SY5Y: Expresión del tránscrito $\beta 2$-quimerina y baja presencia de la variante $\beta 1-\mathrm{CHNdel}$ ex7p. Esta tendencia de expresión se mantuvo con las líneas LN-229 y T989, que expresaron mayoritariamente $\beta 2$-quimerina aunque bastante por debajo de los niveles de la línea celular de referencia, y en las que se detectó una menor expresión de $\beta 1-\mathrm{CHNdel}$ ex7p. En el caso de la muestra de LN-18, los niveles de expresión de $\beta 2$-quimerina fueron muy bajos, y no se detectó la variante $\beta 1$ CHNdel ex7p. Para la línea celular LN-443, las expresiones tanto de la isoforma $\beta 2-$ quimerina, como de la variante $\beta 1-\mathrm{CHNdel}$ ex7p fueron marcadamente superiores a las de la muestra referencia, pero la isoforma $\beta 2$-quimerina siguió expresándose en una proporción mucho mayor que la variante de splicing $\beta 1-\mathrm{CHNdel} \mathrm{ex7p.}$

En estos experimentos, además de la expresión de isoformas truncadas, es relevante la disminución de la expresión de $\beta 2$-quimerina siendo, en algunos casos, indetectable. 


\section{II.3. ESTUDIO DE LA REGULACIÓN DE LA TRANSCRIPCIÓN DEL GEN CHN2.}

La transcripción de un gen está regulada, en parte, por la región promotora de este gen. En la familia de las quimerinas sólo se han descritos las características estructurales de uno de los promotores del gen CHN1. Este gen presenta, al igual que el gen $C H N 2$, inicio alternativo de la transcripción. El promotor descrito regula la transcripción de la isoforma $\alpha 1$-quimerina y se encuentra en la región que corresponde a la secuencia del intrón 6 del gen. Este promotor está poco caracterizado y no se han localizado cajas TATA, ni motivos de iniciación ${ }^{86}$.

En este trabajo nos planteamos estudiar mecanismos de regulación de la transcripción del gen CHN2, cuya región promotora del gen CHN2 no ha sido estudiada hasta el momento; para ello, se realizó un estudio teórico de las secuencias 5'UTR adyacentes al inicio de la traducción de las dos isoformas codificadas por este gen.

\section{3.a. Análisis bioinformático de los promotores de 61-y 62-quimerina.}

A través del programa FirstEF $F^{92}$ (http://rulai.cshl.org/tools/FirstEF), se localizaron dos promotores diferentes en el gen $\mathrm{CHN2}$, encargados de regular de manera independiente la transcripción de las isoformas $\beta 1$ - y $\beta 2$-quimerina. No se encontraron secuencias de cajas TATA o CAAT en estos promotores, pero el programa predijo una isla CpG en el promotor del tránscrito $\beta 2$-quimerina.

Uno de los mecanismos de regulación epigenéticos más estudiados y más comunes en el silenciamiento de los genes supresores de tumores es la metilación del promotor. No todos los promotores son susceptibles a este tipo de regulación. Un requisito es la presencia de islas CpG (agrupaciones de dinucleótidos CG) en la región cercana al inicio de la transcripción.

Las secuencias susceptibles de actuar como promotores fueron estudiadas con un programa de predicción de islas CpGs: CpG Island Searcher ${ }^{163}$ (http://www.uscnorris.com/cpgislands2). El programa consideró islas CpG a secuencias que cumplieran las siguientes características: un porcentaje de nucleótidos C-G superior al 55\%, una proporción de CpGs observadas frente a CpGs esperadas del 0,65 y un tamaño de secuencia de, al menos, 500 pb. 
La secuencia identificada como promotor de la $\beta 1$-quimerina por el programa FisrtEF no presentó islas $\mathrm{CpG}$, pero si se observó una isla $\mathrm{CpG}$ en el promotor de la $\beta 2$ quimerina (Fig. 42). Al analizar la secuencia genómica completa del gen CHN2 en busca de islas $\mathrm{CpG}$, se encontró una segunda isla $\mathrm{CpG}$ en el intrón 2 del gen $C H N 2$, a 88 kilobases del exón 1. No parece que esta isla CpG se encargue de la regulación de ninguno de los dos tránscritos, puesto que se encuentra lejos de sus inicios de transcripción.

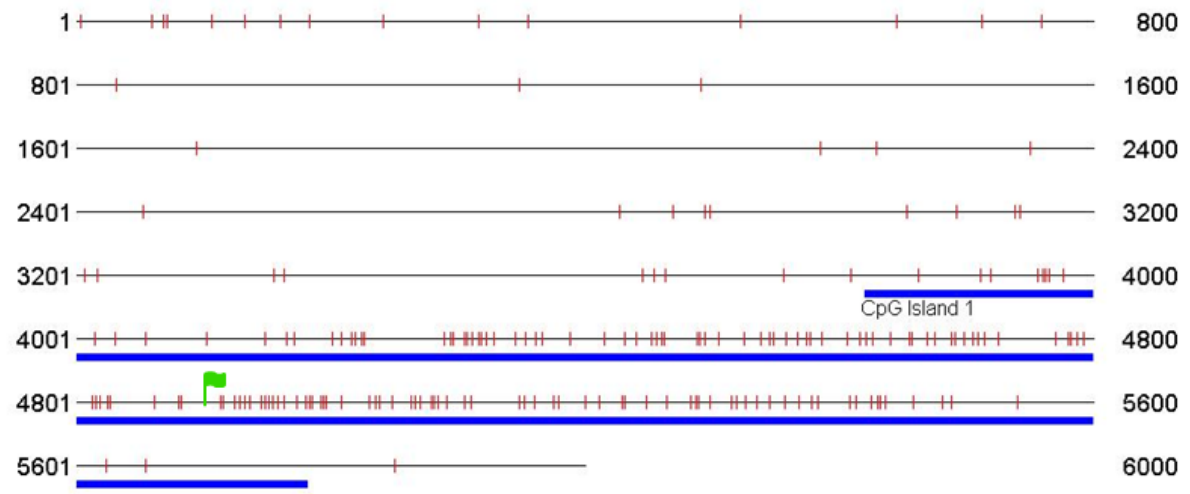

Figura 42: Representación de los dinucleótidos CpG localizados a lo largo de la secuencia del promotor gen CHN2 para el tránscrito $\boldsymbol{\beta} 2$-quimerina. La marca verde indica la posición del inicio de la traducción. Subrayada en azul se marca la secuencia correspondiente a la isla CpG del promotor de la $\beta 2$-quimerina. (Datos obtenidos a través del programa CpG Island Research).

\section{II.3.a.1 Análisis de la metilación del primer promotor del gen CHN2.}

Teniendo en cuenta los datos anteriores, en este trabajo nos planteamos el estudio de la metilación del promotor del gen CHN2 que regula la expresión de la isoforma $\beta 2$-quimerina. Puesto que habíamos observado disminución de la expresión del gen CHN2 en líneas celulares de cáncer de mama (Tabla 18), utilizamos estas muestras para el análisis de la metilación. El estudio se realizó por secuenciación de PCR dependiente de bisulfito del DNA genómico (BSP). Para el diseño del experimento se utilizó el programa Methyl Primer Express (Applied Biosystems), tanto para seleccionar la región de interés dentro de la isla CpG, como para el diseño de los oligonucleótidos específicos de DNA bisulfitado. Se seleccionó la región de la isla CpG más densa en dinucleótidos $C p G$, amplificando por PCR dependiente de bisulfito una región de 307 pb que comprendía 36 dinucleótidos CpG y el inicio de la traducción de la isoforma $\beta 2$ quimerina (Fig. 43). 


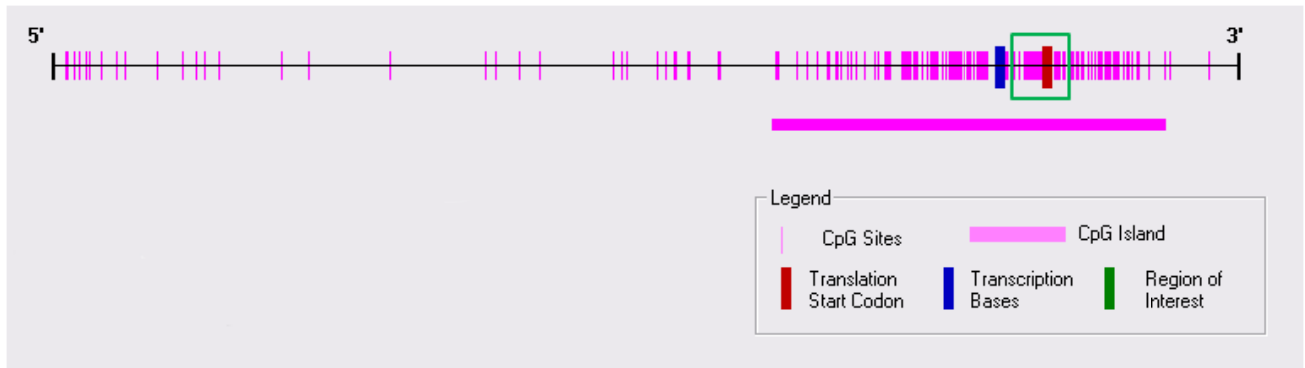

Figura 43: Secuencia del promotor de la isoforma $\beta 2$-quimerina, con la localización de la isla CpG. En el recuadro verde aparece señalada la región de estudio de metilación del promotor. (Datos obtenidos con el programa Methy Primer Express).

La región de interés del promotor fue amplificada por BSP en ocho líneas celulares de mama. Los productos de amplificación se clonaron en el vector de clonación pGEM-T Easy y se secuenciaron 6 clones de cada muestra (Fig. 44).

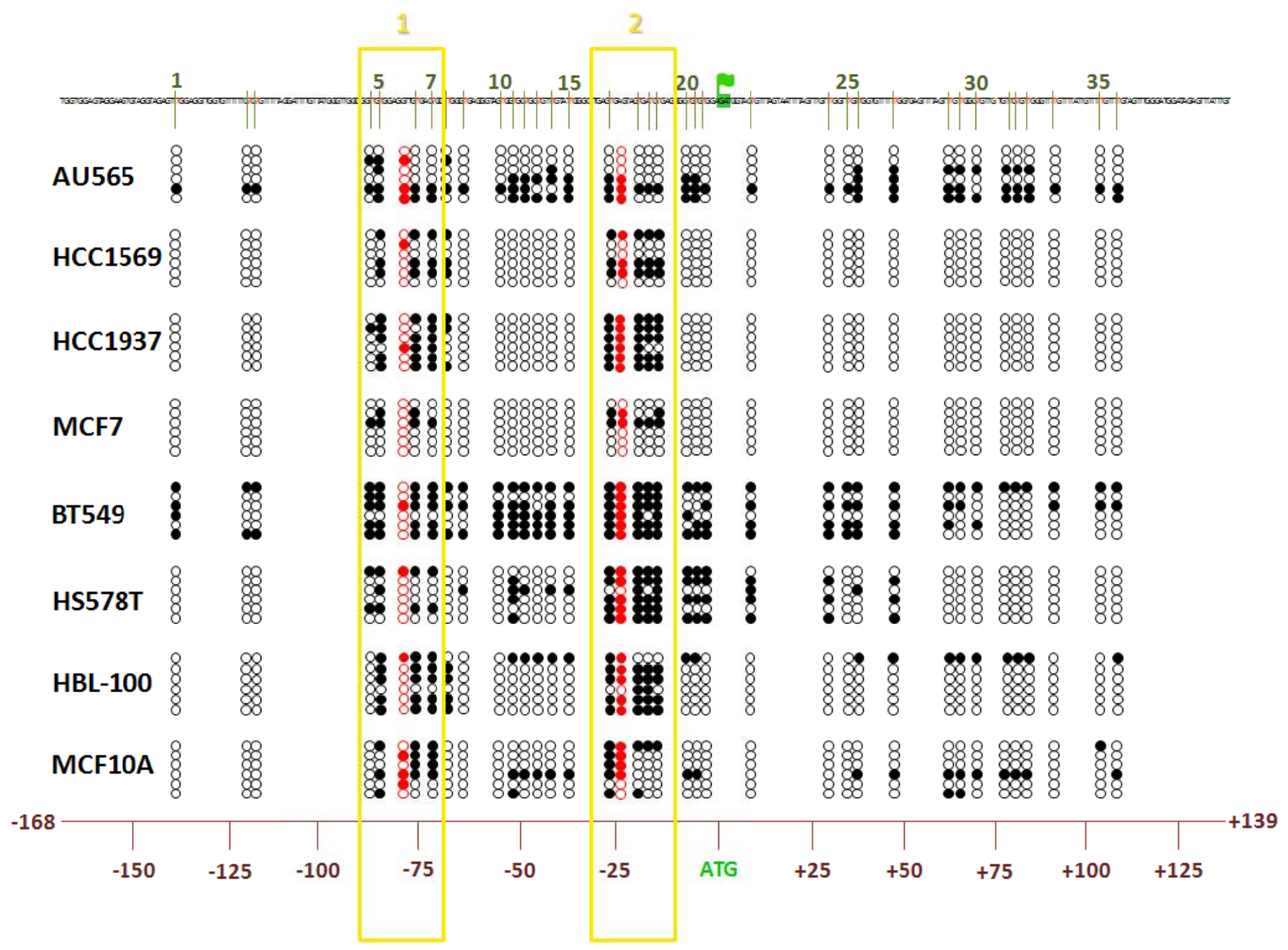

Figura 44: Patrones de metilación de la región de la isla CpG estudiada en las distintas muestras de líneas celulares de cáncer de mama. Cada círculo corresponde a una citosina susceptible de metilación. Los círculos vacíos indican no metilación, los círculos rellenos, metilación de la citosina a la que representan; los círculos rojos pertenecen a citosinas susceptibles de metilación de trinucleótidos CpNpG. Los recuadros amarillos marcan las subregiones de la isla con mayor porcentaje de citosinas metiladas. En la línea horizontal superior se marca el órden de las citosinas susceptibles de metilación dentro de la región a estudio; en la línea inferior, la posición de las citosinas respecto al ATG inicial. 
Nuestros resultados muestran metilación del promotor. Esta metilación se concentra en dos subregiones: la primera incluye las citosinas susceptibles de metilación situadas entre las posiciones -87 y - 72 del promotor, y la segunda incluye las posiciones 27 a -15. Comprobamos que existen distintos patrones de metilación de la región del promotor del gen CHN2 en las distintas líneas celulares. La línea celular AU-565 presentó unos niveles de metilación del 36\% a lo largo de toda la región (Tabla 20). Unos niveles similares se observaron en las líneas celulares MCF10A (20,6\%) y HCC1569 (15,8\%). La línea celular HCC1937, a pesar de tener bajos niveles de metilación totales (21,5\%), presentó una acumulación de los dinucleótidos CpG metilados en dos subregiones de este promotor: $61 \%$ de citosinas metiladas en la subregión 1, y 93,3\% en la subregión 2. (Fig. 44). Esta acumulación de citosinas metiladas en las subregiones 1 y 2 se observó también en la línea HBL-100. En la línea celular HS578T, la acumulación de citosinas metiladas se centró sólo en la subregión 2 (90\%). MCF7 no presentó metilación del promotor de CHN2, mientras que en la línea BT-549, más $60 \%$ de las citosinas totales estaban metiladas.

Tabla 20: Porcentaje de citosinas metiladas en el promotor de CHN2 respecto al total de citosinas susceptibles de metilación de esta región. Los cálculos están agrupados en citosinas totales, y en las dos subregiones con mayor porcentaje de citosinas metiladas.

\begin{tabular}{|l|r|r|r|}
\hline Línea celular & Promotor & Subregión 1 & Subregión 2 \\
\hline AU656 & $36,00 \%$ & $46,70 \%$ & $30,00 \%$ \\
\hline HCC1569 & $15,80 \%$ & $33,30 \%$ & $50,00 \%$ \\
\hline HCC1937 & $21,50 \%$ & $\mathbf{6 0 , 0 0 \%}$ & $\mathbf{9 3 , 3 0 \%}$ \\
\hline MCF7 & $6,10 \%$ & $20,00 \%$ & $26,70 \%$ \\
\hline BT549 & $\mathbf{6 1 , 0 0 \%}$ & $\mathbf{7 0 , 0 0 \%}$ & $\mathbf{9 6 , 7 0 \%}$ \\
\hline HS578T & $29,80 \%$ & $33,30 \%$ & $\mathbf{9 0 , 0 0 \%}$ \\
\hline HBL100 & $26,30 \%$ & $\mathbf{5 3 , 3 0 \%}$ & $\mathbf{8 0 , 0 0 \%}$ \\
\hline MCF10A & $20,60 \%$ & $46,70 \%$ & $43,30 \%$ \\
\hline
\end{tabular}

En el análisis de los patrones de citosinas metiladas identificamos dos citosinas que no pertenecían a un dinucleótido $\mathrm{CpG}$, sino a un trinucleótido $\mathrm{CpNpG}$, que aparecían metiladas con una frecuencia alta y en distintas muestras (Fig. 44).

Para estudiar la relación entre la metilación del promotor y la regulación de los niveles de expresión de la isoforma $\beta 2$-quimerina, decidimos analizar la expresión de este gen tras tratamiento con AZA. Para ello escogimos dos líneas celulares de mama: AU565, una línea celular con unos niveles de expresión del tránscrito $\beta 2$-quimerina ligeramente 
superior a la expresión observada en la muestra control MCF10A (Tabla 18) y unos niveles de metilación del promotor del 36\% (Tabla 20); y BT549, que no expresa el tránscrito $\beta 2$ quimerina y presenta una metilación del promotor del gen CHN2 superior al 60\%. Estas dos líneas celulares se cultivaron en medio de crecimiento suplementadas con el agente desmetilante 5-aza-2'-deoxicitidina (AZA).

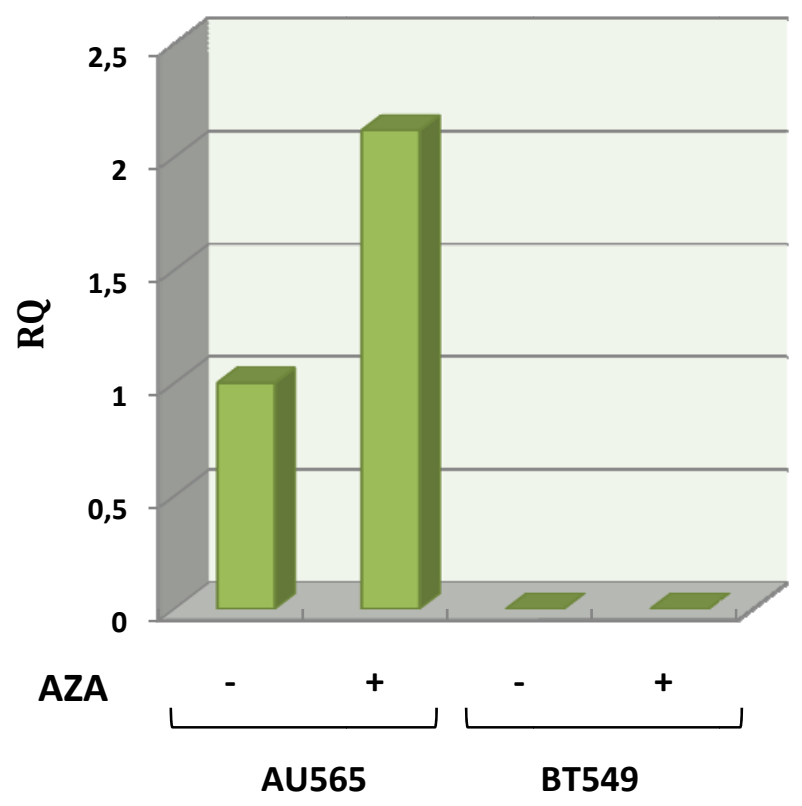

Figura 45: Resultados de PCR cuantitativa relativa para el tránscrito $\boldsymbol{\beta} 2$-quimerina en líneas celulares tratadas con AZA. Se representa la media de dos experimentos, cada uno realizado por triplicado.

La PCR cuantitativa relativa utilizada para medir de los niveles de expresión del tránscrito $\beta 2$-quimerina en las muestras tratadas y sin tratar con AZA mostró un aumento de la expresión en la línea celular AU565 de 2 veces, mientras que la línea celular con el promotor de CHN2 metilado, BT-549, no reexpresó el transcrito $\beta 2$-quimerina tras el tratamiento con AZA (Fig. 45). 


\section{DISCUSIÓN}





\section{EL GEN CHN2 Y EL CÁNCER.}

El estudio de los mecanismos moleculares del gen CHN2 es esencial, ya que las proteínas que codifica actúan como reguladoras negativas de Rac, una proteína Rho GTPasa implicada en una gran cantidad de procesos celulares asociados con proliferación, transformación maligna e invasión, y cuya desregulación está relacionada con diversas enfermedades como el cáncer ${ }^{164}$. En estudios previos a este trabajo ${ }^{33}$ se ha descrito una asociación entre la disminución del tránscrito $\beta 2$-quimerina y la progresión del cáncer; su sobreexpresión en células tumorales de mama inhibe la proliferación y la metástasis a través de la Rho GTasa Rac ${ }^{90,91}$. Estos datos sugieren que la disminución de la expresión de $\beta 2$-quimerina en cáncer no es accidental, sino que es una diana en la transformación maligna y que su restitución puede, potencialmente, inducir a una "normalización" en el comportamiento de la célula. Estas evidencias apuntan a que el gen CHN2 puede ser un gen supresor de tumores.

Los genes supresores de tumores codifican proteínas que intervienen en la inhibición de la proliferación, promueven la muerte celular o reparan el DNA. Deben tener inactivos ambos alelos para que se produzca una pérdida de función de la proteína, lo que deriva en la transformación maligna de la célula (Teoría del doble impacto de Knudson ${ }^{136}$ ). Sus alteraciones más comunes son la aparición de mutaciones inactivadoras, aunque también pueden deberse a la generación de aberraciones en el splicing, o a alteraciones epigenéticas que conducen a la disminución de la expresión del gen o a su silenciamiento; además de alteraciones cromosómicas que modifican uno o varios loci.

En este trabajo no hemos encontrado mutaciones patogénicas que se pudieran asociar al desarrollo de los tres tipos tumorales estudiados: mama, glioblastomas y síndromes mielodisplásicos. Aunque en otros genes Rho GAP sí se han encontrado mutaciones, como en el alelo no delecionado del gen $G R A F^{143}$ en síndrome mielodisplásico o en el gen $D L C 1$ en varios tipos de cáncer ${ }^{141}$; la ausencia de mutaciones no descarta que el gen CHN2 pueda ser un gen supresor tumoral. Existen casos de genes asociados con cáncer, como RAC1 u otros genes de la familia de las Rho GTPasas, en los que nunca se han encontrado mutaciones patogénicas, pero si presentan otro tipo de 
alteraciones asociadas con el desarrollo del tumor. No podemos descartar que puedan aparecen en otros tipos tumorales diferentes a los estudiados.

Aunque el estudio del gen CHN2 no permitió encontrar mutaciones patogénicas, si hemos observado polimorfismos, algunos de ellos descritos por primera vez en este trabajo. Los polimorfismos son pequeñas variaciones en la secuencia del DNA, responsables, en algunos casos, de la variedad de fenotipos entre individuos, ya que pueden derivar en pequeños cambios de la actividad del gen. Ocasionalmente pueden estar relacionados con una mayor susceptibilidad a padecer una determinada enfermedad, aunque nunca es la causa directa de la misma. El alelo T del polimorfismo IVS5+7C>T del gen CHN2, según estudios bioinformáticos teóricos llevados a cabo con el programa Human Splicing Finder ${ }^{168}$ (http://www.umd.be/HSF), modifica la secuencia unión de un potenciador del splicing (ESE); el alelo A del polimorfismo c.366G>A (p.S122S) produce la pérdida de una secuencia ESE y un sitio teórico de unión de un inhibidor del splicing (ESS); y el alelo $\mathrm{G}$ del polimorfismo c.611A>G (p.H203R), asociado previamente con la predisposición a la esquizofrenia ${ }^{169}$, pierde, en teoría, una secuencia ESE y una secuencia ESS, y los programas de predicción de mutaciones $p M U T^{130}$ (http://mmb2.pcb.ub.es:8080/PMut) y Polyphen ${ }^{170 ~(h t t p: / / g e n e t i c s . b w h . h a r v a r d . e d u / ~}$ $\mathrm{pph}$ ) consideraron el cambio de histidina a arginina derivado del alelo $\mathrm{G}$ como patogénico o posiblemente perjudicial (Fig. 46A).

La comparación de la distribución de los distintos genotipos de estos tres polimorfismos entre pacientes con cáncer frente a individuos sanos no mostró diferencias significativas. La ausencia de asociación de los tres polimorfismos con los tres tipos de tumores estudiados debe ser analizada considerando que partimos de un tamaño de población limitado y que la selección de los SNPs se realizó teniendo en cuenta predicciones bioinformáticas. El estudio de polimorfismos del gen $D L C 1$, por ejemplo, no mostró asociación del SNP -29A>T en carcinoma nasofaríngeo y, sin embargo, otros tres polimorfismos del gen están asociados con la predisposición a sufrir carcinoma hepatocelular. No se descarta, por tanto, que estos polimorfismos u otros del gen CHN2 puedan estar implicados en otros tipos tumorales. 
A

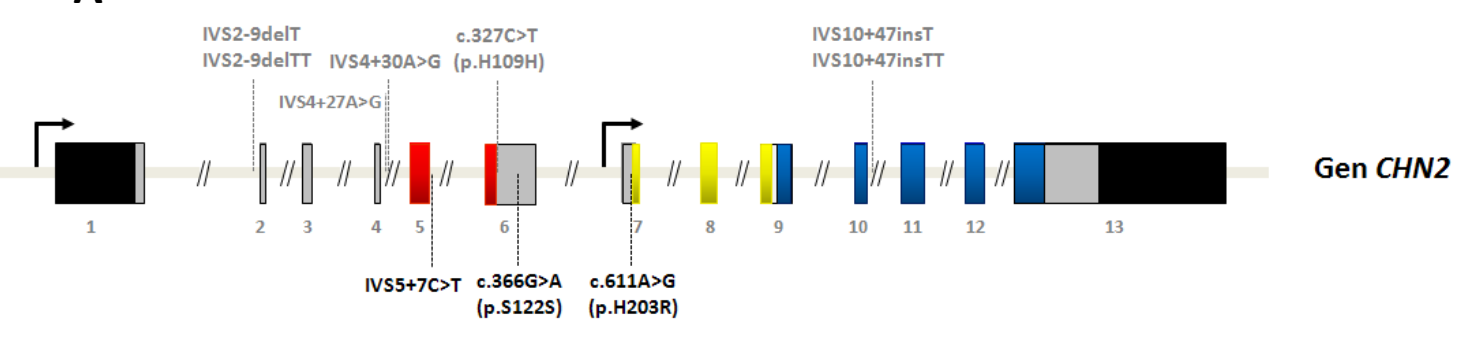

B

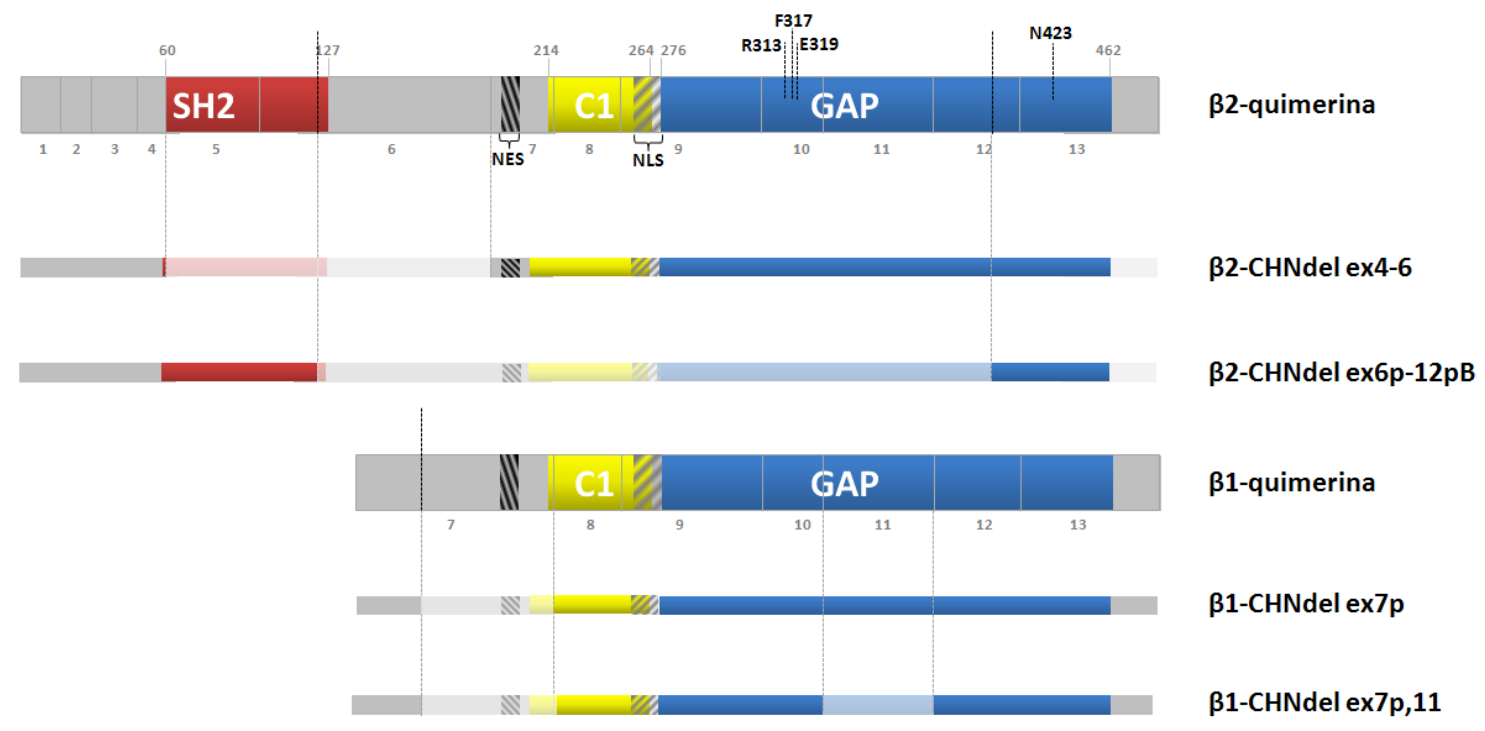

Figura 46: El gen CHN2 y de los tránscritos más representativos. (A). Representación de los exones y las secuencias intrónicas flanqueantes edl gen $\mathrm{CHN2}$, sobre la que se representan los polimorfismos localizados durante el estudio de búsqueda de mutaciones patogénicas. (B) Esquema de los dos tránscritos generados por inicio alternativo de la transcripción, y de cuatro isoromas truncadas. Sobre la isoforma completa $\beta 2$-quimerina apareen señalados los residuos más importantes en la interacción con Rac y en la función GAP de la proteína, además de las señales NLS y NES.

La ausencia de alteraciones a nivel genómico que pudieran apoyar la hipótesis del gen CHN2 como supresor de tumores nos condujo al estudio de la expresión de este gen. Las aproximaciones a este análisis en estudios previos no discriminaban entre la presencia de los tránscritos $\beta 1$ - y $\beta 2$-quimerina ${ }^{90,91}$. Para evitar este inconveniente, diseñamos PCRs anidadas específicas de cada isoforma del gen CHN2. El análisis de la expresión reveló, en primer lugar, la ausencia de tránscrito $\beta 2$-quimerina en algunas muestras de distintas líneas celulares derivadas de cáncer (Fig.31). Demostramos así lo que ya se había observado en otros trabajos, que existe una ausencia o una disminución de expresión del gen CHN2 en cáncer de mama y glioblastoma de alto grado ${ }^{90,91}$. El análisis de la expresión 
diferencial del gen CHN2 mostró, además, que la isoforma $\beta 1$-quimerina, hasta el momento sólo detectada en tejido testicular de rata ${ }^{90,91}$, se expresa también en otros tipos celulares humanos (Fig. 31). Este análisis inicial de la expresión sirvió también para describir un fenómeno muy común en la mayoría de los genes, pero desconocido hasta el momento en las quimerinas, el splicing alternativo, un proceso por el que, durante la maduración del RNA, la maquinaria celular retiene intrones o elimina exones, originando que, a partir de la transcripción de un gen, se generen múltiples mRNAs. En este estudio describimos una amplia variedad de isoformas truncadas derivadas tanto del pre-mRNA de $\beta 1$-quimerina como de $\beta 2$ - La mayoría de las isoformas truncadas derivadas del tránscrito $\beta 2$-quimerina podrían considerarse como variantes aberrantes ya que pierden fragmentos de exones sin seguir ningún patrón conocido; sin embargo, otras variantes parecen seguir un criterio común de deleción de exones; por ejemplo, la deleción recurrente del exón 7p, cuya secuencia de reconocimiento de la maquinaria del spliceosoma es canónica.

La aparición de nuevas variantes de splicing no pudo relacionarse con alteraciones en cis, es decir, con mutaciones en el gen CHN2. Aunque parte de los polimorfismos encontrados durante la búsqueda de mutaciones presentaran cambios in silico en las secuencias ESE y ESS, estos cambios no tienen relación con los patrones de splicing detectados en las variantes descritas. El dilema es saber si estas variantes de splicing se deben a una alteración en trans, por alteraciones en los genes relacionados con el spliceosoma, o si, por el contrario, su generación ocurre de manera normal; y si, de ser un splicing aberrante, sería causa o efecto de la desregulación de las células tumorales.

El estudio funcional de algunas de estas variantes mostró que la variante $\beta 2$ CHNdel ex6p-12pB, un ejemplo de una isoforma truncada derivada de $\beta 2$-quimerina carece por completo de actividad GAP (Fig. 38); su localización y su patrón de expresión hacen pensar que sufre ubiquitinización y se acumula en agregados celulares a la espera de su degradación por el proteasoma (Fig. 35A). La variante $\beta 2-\mathrm{CHNdel}$ ex4-6, por su parte, presenta una localización similar a la isoforma completa $\beta 1$-quimerina, incluso tras tratamiento con PMA (Fig. 35A y 36); ambas presentan también unos porcentajes de disminución de Rac activo similares (Fig. 38 y 39). Esto se debe, probablemente, a la gran 
similitud de secuencia y estructura entre ambas; las dos isoformas carecen del dominio $\mathrm{SH} 2$, lo que favorece que estas proteínas se encuentren siempre en su conformación activa, haciendo que tanto su traslocación como su actividad GAP sean más efectivas que las de la isoforma completa $\beta 2$-quimerina. Un hecho llamativo es la localización nuclear de las variantes que presentan deleción parcial del exón 7. Creemos que la localización nuclear se debe a la pérdida de una señal de exportación nuclear (NES) codificada en la parte delecionada del exón 7, lo que favorecería que una señal de localización nuclear críptica (NLS) codificada en el exón 9 pudiera guiar la exportación de estas variantes al interior del núcleo (Fig. 46B). Las proteínas DLC-1 ${ }^{86}$ y MgcRacGAP ${ }^{171}$ son un ejemplo de otras Rho-GAPs con señales nucleares NLS que tienen un transporte muy activo y regulado entre el núcleo y el citoplasma. Aunque la función que puedan ejercer las proteínas Rho-GAPs dentro del núcleo no está muy clara, se sabe que existe un reservorio de Rac activo nuclear que regula las vías de señalización que controlan la expresión génica y la progresión del ciclo celular ${ }^{172}$. Este reservorio nuclear de Rac y la alteración del dominio $\mathrm{C} 1$ debido a la pérdida de sus cuatro primeros aminoácidos, esenciales para su función, pueden ser la causa de la mayor actividad GAP de la isoforma truncada $\beta 1$ CHNdel ex7p, que inactiva un mayor porcentaje de Rac-GTP que la forma completa $\beta 1$ quimerina (Fig. 39). Se presupone que, al no tener que activarse y traslocarse a membrana para ejercer su actividad sobre Rac, la eficiencia será mayor, aún así hay que tener en cuenta que la actividad GAP de las quimerinas sobre Rac no sólo se basa en la disminución de Rac activo global de la célula, sino que es muy importante su acción local sobre reservorios de Rac localizados y en momentos celulares determinados. La duda surge con la variante $\beta 1-\mathrm{CHNdel}$ ex7p,11. La sobreexpresión de esta proteína disminuye los niveles de Rac-GTP de la célula un $25 \%$, aunque pierde parte del dominio GAP, si bien es cierto que conserva la arginina 313 del dedo de arginina, los aminoácidos de interacción con Rac F317 y E319, y la asparragina 423, importante para la catálisis (Fig. 46B). Habría que profundizar si la disminución de Rac activo se debe a la actividad GAP de la propia variante $\beta 1-\mathrm{CHNdel}$ ex7p,11, o si la isoforma truncada favorece la inactivación de Rac de manera indirecta. Hemos encontrado evidencias de la interacción de $\beta 1$ CHNdel ex7p,11 con el complejo Rac-PBD-GST, pero desconocemos si esta interacción proteica es con la proteína Rac o con otras proteínas presentes en el complejo. La interacción podría ser directa con la molécula Rac, ya que esta variante conserva los 
aminoácidos F317 y E319 descritos en ß2-quimerina como necesarios para la interacción con Rac, y se ha demostrado que mutantes de a1-quimerina sin actividad GAP pueden unirse a Rac1 prolongando su interacción ${ }^{173}$; sin embargo, la variante $\beta 2-\mathrm{CHNdel}$ ex6p$12 \mathrm{pB}$, que carece por completo del dominio GAP y tampoco presenta los aminoácidos F317 y E319, también coprecipita junto a este complejo, de manera que si ambas isoformas truncadas utilizan los mismos mecanismos para la interacción con el complejo, no parece que lo hagan a Rac, o por lo menos, no a través los residuos descritos hasta el momento.

La expresión de $\beta 2$-CHNdel ex4-6 y de las variantes derivadas de $\beta 1$-quimerina carentes el exón $7 p(d e / 7 p)$ se detectan por PCR cuantitativa en muestra de líneas tumorales de mama y glioblastomas, mientras que la isoforma completa $\beta 1$-quimerina y algunas de las variantes de splicing derivadas de ella que conservan intacto el exón 7, no aparecen expresadas (Tablas 18 y 19). Esto datos en líneas tumorales hacen pensar que la maquinaria de maduración del pre-mRNA reconoce como sitio de splicing natural el sitio críptico situado en el interior del exón 7, en vez del situado al final del exón. En el caso de las líneas tumorales de mama, la función de la isoforma $\beta 1$-quimerina completa podría ser suplida por la variante de splicing $\beta 2-C H N d e l$ ex4-6.

La disminución de la expresión de la forma completa $\beta 2$-quimerina es más compleja de analizar, ya que en la cuantificación de este tránscrito se incluye la cuantificación de las variantes de splicing $\beta 2-\mathrm{CHNdel}$ ex3, $\beta 2-\mathrm{CHNdel}$ ex6p-12pB y $\beta 2$ CHNdel ex7p-13pB. Por eso, en aquellos casos en los que la expresión de $\beta 2$-quimerina es mayor a la de la muestra control, no podemos descartar que se trate de una falsa señal y lo que se esté detectando es un aumento de variantes aberrantes. En cualquier caso, más de la mitad de las muestras estudiadas de mama y glioblastoma presentan una disminución de la expresión de $\beta 2$-quimerina respecto al control, tal y como ya se había observado previamente . $^{108,111}$.

El mecanismo de regulación de los genes de la familia de las quimerinas había sido poco estudiado hasta el momento. Sólo se habían caracterizado algunos motivos reguladores en el promotor que controla la expresión del tránscrito a1-quimerina en el gen $C H N 1^{90,91}$. En el gen $C H N 2$, describimos por primera vez la presencia de una isla CpG en el primer promotor de $C H N 2$, que regula la expresión del tránscrito $\beta 2$-quimerina, 
aunque recientemente se ha observado metilación del promotor de CHN2 en tumores de hígado de ratón tras tratamiento con fenobarbital ${ }^{92,93}$. En nuestras muestras, la hipermetilación del promotor completo no parece ser el mecanismo de silenciamiento el gen, ya que sólo ocurre en una única muestra, la cual no recupera la expresión del tránscrito $\beta 2$-quimerina tras el tratamiento con $A Z A$, pero es factible que la hipermetilación específica de dos subregiones del promotor inhiba la interacción de factores de transcripción, regulando su expresión, como ocurre, por ejemplo, en el gen IFN $\gamma$ durante el desarrollo de las células T colaboradoras, en el que la metilación de una citosina concreta de un dinucleótido CpG bloquea la unión de factores de transcripción al promotor, lo que inhibe la expresión del gen ${ }^{94}$. Esta hipótesis concuerda con la evidencia de que la línea AU565, que presenta un bajo porcentaje de metilación global pero mayor nivel de metilación en dos subregiones acotadas del promotor (Fig. 44) duplique su expresión del tránscrito completo $\beta 2$-quimerina tras tratamiento con AZA. Podemos pensar así, que la metilación de las dos subregiones del primer promotor del gen CHN2 conduce a un silenciamiento rápido del gen, y que la hipermetilación del promotor está asociada a un silenciamiento a largo plazo en el que intervienen otros mecanismos inhibidores de la transcripción, y por ello no se consigue la reexpresión del gen al tratar la célula con AZA.

\section{OTRAS ENFERMEDADES ASOCIADAS AL GEN CHN2.}

Las proteínas de la familia de las quimerinas tienen funciones relacionadas con el desarrollo del sistema nervioso. La $\alpha 2$-quimerina interacciona con el receptor de efrinas EphA4, influyendo en el proceso de colapso del cono axonal en crecimiento ${ }^{174}$. Además se ha observado que mutaciones activadoras en el gen $C H N 1$ se asocian con el síndrome de la retracción de Duane $e^{115}$, causada por alteraciones a nivel de los axones de las neuronas motoras. El gen CHN2 está también implicado en procesos de plasticidad neuronal, presenta una alta expresión en el cerebro durante el desarrollo embrionario y parece intervenir en la generación de las conexiones neuronales a través de su interacción con EphA4 ${ }^{129}$. Por otro lado, las quimerinas, como reguladoras de la actividad de las Rho GTPasas, intervienen en procesos neuronales a través de la regulación de su vía de transducción de señales. Las Rho GTPasas están asociadas con la regulación de la 
plasticidad estructural de las espinas y las dendritas, y aparecen implicadas en procesos neuronales como la migración y polarización neuronal, la orientación axonal y la formación de la sinapsis neuronal ${ }^{117}$.

La adicción al tabaco es un comportamiento complejo en el que hay implicados muchos factores ambientales, pero está también influido por factores genéticos, tal y como se ha demostrado en diversos estudios en gemelos, por análisis de ligamiento y estudios de genes candidatos ${ }^{175}$, tanto a nivel de inicio y continuidad en el consumo, como en cuanto a la dependencia a la nicotina. El abuso del alcohol es un trastorno ligado a la adicción a sustancias. Se conocen multitud de factores genético que aumentan el riesgo de un individuo a padecer alcoholismo ${ }^{176,177}$. Existen casos en los que se correlacionan los datos genéticos del abuso del alcohol con el consumo de tabaco ya que muchos de los genes implicados en la adicción al tabaco también están implicados en el abuso del alcohol ${ }^{178}$.

En nuestro estudio observamos asociación del alelo A del polimorfismo c.366G>A (p.S122S) con la susceptibilidad a ser fumador. Esta asociación del polimorfismo con la dependencia al tabaco se observa en los fumadores de mayor edad, lo que hace pensar que aquellos fumadores que poseen el alelo A tienen mayor dificultad a dejar de fumar, por lo que siguen siendo fumadores a edades muy altas. Sin embargo, esta asociación no está relacionada con el consumo de nicotina diario. La relación entre este polimorfismo y la adicción parece ser específica de la nicotina, porque no la hemos encontrado en individuos con adicción al alcohol.

La posible relación del gen CHN2 con la capacidad de dejar de fumar de un fumador, ya había sido insinuada previamente en un estudio de GWAS (Genome-wide Association S $\underline{t}$ (udy) que observaba asociación de ciertos polimorfismos del gen CHN2 con la capacidad de dejar de fumar de los individuos estudiados ${ }^{167}$. Por otra parte se ha observado una disminución en los niveles de $\beta$-quimerina en las células tratadas con nicotina ${ }^{166}$. 
CONCLUSIONES 

1. El gen CHN2 no presenta mutaciones patogénicas que puedan asociarse con la progresión del cáncer en los tres tipos de tumores estudiados: Tumores de mama, glioblastomas y síndrome mielodisplásico.

2. Los polimorfismos estudiados del gen CHN2 no están asociados con la predisposición a desarrollar cáncer de mama, glioblastomas y síndrome mielodisplásico.

3. El polimorfismo c.366 G>A (p.S122S) está asociado con la adicción al tabaco, concretamente con la prolongación de la adicción en individuos mayores de 65 años; mientras que no se encuentra asociación con la adicción al alcohol.

4. El gen $\mathrm{CHN2}$ genera, por procesamiento alternativo de su RNA, hasta 17 isoformas truncadas, además de las dos isoformas que se producen por inicio alternativo de la transcripción. La generación de isoformas truncadas aberrantes puede ser una de las alteraciones sufridas en este gen en el proceso tumoral.

5. El primer promotor del gen $C H N 2$ es susceptible a metilación, aunque no se puede confirmar que la hipermetilación de su isla CpG que sea la causa de la disminución de la expresión o del silenciamiento de la expresión, al menos en las muestras tumorales estudiadas. 

BIBLIOGRAFÍA 

1. Ellenbroek, S.I. \& Collard, J.G. Rho GTPases: functions and association with cancer. Clin Exp Metastasis 24, 657-72 (2007).

2. Vetter, I.R. \& Wittinghofer, A. The guanine nucleotide-binding switch in three dimensions. Science 294, 1299-304 (2001).

3. Schmidt, A. \& Hall, A. Guanine nucleotide exchange factors for Rho GTPases: turning on the switch. Genes Dev 16, 1587-609 (2002).

4. Moon, S.Y. \& Zheng, Y. Rho GTPase-activating proteins in cell regulation. Trends Cell Biol 13, 13-22 (2003).

5. DerMardirossian, C. \& Bokoch, G.M. GDIs: central regulatory molecules in Rho GTPase activation. Trends Cell Biol 15, 356-63 (2005).

6. Aspenstrom, P., Fransson, A. \& Saras, J. Rho GTPases have diverse effects on the organization of the actin filament system. Biochem J 377, 327-37 (2004).

7. Daub, H., Gevaert, K., Vandekerckhove, J., Sobel, A. \& Hall, A. Rac/Cdc42 and p65PAK regulate the microtubule-destabilizing protein stathmin through phosphorylation at serine 16. J Biol Chem 276, 1677-80 (2001).

8. Fukata, M. et al. Rac1 and Cdc42 capture microtubules through IQGAP1 and CLIP-170. Cell 109, 873-85 (2002).

9. Ridley, A.J. Rho family proteins: coordinating cell responses. Trends Cell Biol 11, 471-7 (2001).

10. Miralles, F., Posern, G., Zaromytidou, A.I. \& Treisman, R. Actin dynamics control SRF activity by regulation of its coactivator MAL. Cell 113, 329-42 (2003).

11. Jaffe, A.B. \& Hall, A. Rho GTPases: biochemistry and biology. Annu Rev Cell Dev Biol 21, 247-69 (2005).

12. Hadano, S. et al. A gene encoding a putative GTPase regulator is mutated in familial amyotrophic lateral sclerosis 2. Nat Genet 29, 166-73 (2001).

13. Rolfe, B.E., Worth, N.F., World, C.J., Campbell, J.H. \& Campbell, G.R. Rho and vascular disease. Atherosclerosis 183, 1-16 (2005).

14. Johns, D.G., Dorrance, A.M., Leite, R., Weber, D.S. \& Webb, R.C. Novel signaling pathways contributing to vascular changes in hypertension. J Biomed Sci 7, 431-43 (2000).

15. Gu, Y. et al. Hematopoietic cell regulation by Rac1 and Rac2 guanosine triphosphatases. Science 302, 445-9 (2003).

16. Williams, D.A. et al. Dominant negative mutation of the hematopoietic-specific Rho GTPase, Rac2, is associated with a human phagocyte immunodeficiency. Blood 96, 164654 (2000).

17. Ambruso, D.R. et al. Human neutrophil immunodeficiency syndrome is associated with an inhibitory Rac2 mutation. Proc Natl Acad Sci U S A 97, 4654-9 (2000).

18. Lemahieu, V., Gastier, J.M. \& Francke, U. Novel mutations in the Wiskott-Aldrich syndrome protein gene and their effects on transcriptional, translational, and clinical phenotypes. Hum Mutat 14, 54-66 (1999).

19. Ellis, S. \& Mellor, H. Regulation of endocytic traffic by rho family GTPases. Trends Cell Biol 10, 85-8 (2000).

20. Lerm, M., Schmidt, G. \& Aktories, K. Bacterial protein toxins targeting rho GTPases. FEMS Microbiol Lett 188, 1-6 (2000).

21. Didsbury, J., Weber, R.F., Bokoch, G.M., Evans, T. \& Snyderman, R. rac, a novel ras-related family of proteins that are botulinum toxin substrates. J Biol Chem 264, 16378-82 (1989).

22. Valencia, A., Chardin, P., Wittinghofer, A. \& Sander, C. The ras protein family: evolutionary tree and role of conserved amino acids. Biochemistry 30, 4637-48 (1991).

23. Ridley, A.J., Paterson, H.F., Johnston, C.L., Diekmann, D. \& Hall, A. The small GTP-binding protein rac regulates growth factor-induced membrane ruffling. Cell 70, 401-10 (1992).

24. Sugihara, K. et al. Rac1 is required for the formation of three germ layers during gastrulation. Oncogene 17, 3427-33 (1998). 
25. Roberts, A.W. et al. Deficiency of the hematopoietic cell-specific Rho family GTPase Rac2 is characterized by abnormalities in neutrophil function and host defense. Immunity 10, 183-96 (1999).

26. Dorseuil, O., Reibel, L., Bokoch, G.M., Camonis, J. \& Gacon, G. The Rac target NADPH oxidase p67phox interacts preferentially with Rac2 rather than Rac1. J Biol Chem 271, 838 (1996).

27. Mizuno, T. et al. Regulation of the superoxide-generating NADPH oxidase by a small GTPbinding protein and its stimulatory and inhibitory GDP/GTP exchange proteins. $J$ Biol Chem 267, 10215-8 (1992).

28. Werner, E. GTPases and reactive oxygen species: switches for killing and signaling. $J$ Cell Sci 117, 143-53 (2004).

29. Haataja, L., Groffen, J. \& Heisterkamp, N. Characterization of RAC3, a novel member of the Rho family. J Biol Chem 272, 20384-8 (1997).

30. Mira, J.P., Benard, V., Groffen, J., Sanders, L.C. \& Knaus, U.G. Endogenous, hyperactive Rac3 controls proliferation of breast cancer cells by a p21-activated kinase-dependent pathway. Proc Natl Acad Sci U S A 97, 185-9 (2000).

31. Morris, C.M. et al. The small GTPase RAC3 gene is located within chromosome band 17q25.3 outside and telomeric of a region commonly deleted in breast and ovarian tumours. Cytogenet Cell Genet 89, 18-23 (2000).

32. Jordan, P., Brazao, R., Boavida, M.G., Gespach, C. \& Chastre, E. Cloning of a novel human Rac1b splice variant with increased expression in colorectal tumors. Oncogene 18, 6835-9 (1999).

33. Schnelzer, A. et al. Rac1 in human breast cancer: overexpression, mutation analysis, and characterization of a new isoform, Rac1b. Oncogene 19, 3013-20 (2000).

34. Fiegen, D. et al. Alternative splicing of Rac1 generates Rac1b, a self-activating GTPase. $J$ Biol Chem 279, 4743-9 (2004).

35. Matos, P., Collard, J.G. \& Jordan, P. Tumor-related alternatively spliced Rac1b is not regulated by Rho-GDP dissociation inhibitors and exhibits selective downstream signaling. J Biol Chem 278, 50442-8 (2003).

36. Brown, J.L. et al. Human Ste20 homologue hPAK1 links GTPases to the JNK MAP kinase pathway. Curr Biol 6, 598-605 (1996).

37. Frost, J.A., Xu, S., Hutchison, M.R., Marcus, S. \& Cobb, M.H. Actions of Rho family small G proteins and p21-activated protein kinases on mitogen-activated protein kinase family members. Mol Cell Biol 16, 3707-13 (1996).

38. Westwick, J.K. et al. Rac regulation of transformation, gene expression, and actin organization by multiple, PAK-independent pathways. Mol Cell Biol 17, 1324-35 (1997).

39. Guo, D. et al. A Rac-cGMP signaling pathway. Cell 128, 341-55 (2007).

40. $\mathrm{Wu}, \mathrm{X}$. et al. Rac1 activation controls nuclear localization of beta-catenin during canonical Wnt signaling. Cell 133, 340-53 (2008).

41. Teramoto, H. et al. Signaling from the small GTP-binding proteins Rac1 and Cdc42 to the c-Jun N-terminal kinase/stress-activated protein kinase pathway. A role for mixed lineage kinase 3 /protein-tyrosine kinase 1 , a novel member of the mixed lineage kinase family. $J$ Biol Chem 271, 27225-8 (1996).

42. Nagata, K. et al. The MAP kinase kinase kinase MLK2 co-localizes with activated JNK along microtubules and associates with kinesin superfamily motor KIF3. Embo J 17, 149-58 (1998).

43. Perona, R. et al. Activation of the nuclear factor-kappaB by Rho, CDC42, and Rac-1 proteins. Genes Dev 11, 463-75 (1997).

44. Keely, P.J., Westwick, J.K., Whitehead, I.P., Der, C.J. \& Parise, L.V. Cdc42 and Rac1 induce integrin-mediated cell motility and invasiveness through PI(3)K. Nature 390, 632-6 (1997).

45. Coniglio, S.J., Jou, T.S. \& Symons, M. Rac1 protects epithelial cells against anoikis. J Biol Chem 276, 28113-20 (2001). 
46. Rul, W. et al. Activation of ERK, controlled by Rac1 and Cdc42 via Akt, is required for anoikis. Ann N Y Acad Sci 973, 145-8 (2002).

47. Wennerberg, K. et al. RhoG signals in parallel with Rac1 and Cdc42. J Biol Chem 277, 47810-7 (2002).

48. Joyce, D. et al. Integration of Rac-dependent regulation of cyclin D1 transcription through a nuclear factor-kappaB-dependent pathway. J Biol Chem 274, 25245-9 (1999).

49. Bustelo, X.R., Sauzeau, V. \& Berenjeno, I.M. GTP-binding proteins of the Rho/Rac family: regulation, effectors and functions in vivo. Bioessays 29, 356-70 (2007).

50. Caron, E. \& Hall, A. Identification of two distinct mechanisms of phagocytosis controlled by different Rho GTPases. Science 282, 1717-21 (1998).

51. Cox, D. et al. Requirements for both Rac1 and Cdc42 in membrane ruffling and phagocytosis in leukocytes. J Exp Med 186, 1487-94 (1997).

52. Hakeda-Suzuki, S. et al. Rac function and regulation during Drosophila development. Nature 416, 438-42 (2002).

53. Luo, L. Rho GTPases in neuronal morphogenesis. Nat Rev Neurosci 1, 173-80 (2000).

54. $\mathrm{Ng}$, J. et al. Rac GTPases control axon growth, guidance and branching. Nature 416, 442-7 (2002)

55. Ozdinler, P.H. \& Erzurumlu, R.S. Regulation of neurotrophin-induced axonal responses via Rho GTPases. J Comp Neurol 438, 377-87 (2001).

56. Nobes, C.D. \& Hall, A. Rho GTPases control polarity, protrusion, and adhesion during cell movement. J Cell Biol 144, 1235-44 (1999).

57. Chang, H.Y. \& Ready, D.F. Rescue of photoreceptor degeneration in rhodopsin-null Drosophila mutants by activated Rac1. Science 290, 1978-80 (2000).

58. Puceat, M., Travo, P., Quinn, M.T. \& Fort, P. A dual role of the GTPase Rac in cardiac differentiation of stem cells. Mol Biol Cell 14, 2781-92 (2003).

59. Chiariello, M., Marinissen, M.J. \& Gutkind, J.S. Regulation of c-myc expression by PDGF through Rho GTPases. Nat Cell Biol 3, 580-6 (2001).

60. Olson, M.F., Ashworth, A. \& Hall, A. An essential role for Rho, Rac, and Cdc42 GTPases in cell cycle progression through G1. Science 269, 1270-2 (1995).

61. Turner, $\mathrm{H}$. et al. Rac-1 regulates nuclear factor of activated T cells (NFAT) C1 nuclear translocation in response to Fcepsilon receptor type 1 stimulation of mast cells. J Exp Med 188, 527-37 (1998).

62. Joneson, T. \& Bar-Sagi, D. A Rac1 effector site controlling mitogenesis through superoxide production. J Biol Chem 273, 17991-4 (1998).

63. Bokoch, G.M. Regulation of the phagocyte respiratory burst by small GTP-binding proteins. Trends Cell Biol 5, 109-13 (1995).

64. Qualmann, B. \& Mellor, H. Regulation of endocytic traffic by Rho GTPases. Biochem J 371, 233-41 (2003).

65. Malecz, N. et al. Synaptojanin 2, a novel Rac1 effector that regulates clathrin-mediated endocytosis. Curr Biol 10, 1383-6 (2000).

66. Nie, Z. \& Randazzo, P.A. Arf GAPs and membrane traffic. J Cell Sci 119, 1203-11 (2006).

67. Billuart, P. et al. Oligophrenin-1 encodes a rhoGAP protein involved in X-linked mental retardation. Nature 392, 923-6 (1998).

68. Kutsche, K. et al. Mutations in ARHGEF6, encoding a guanine nucleotide exchange factor for Rho GTPases, in patients with X-linked mental retardation. Nat Genet 26, 247-50 (2000).

69. Allen, K.M. et al. PAK3 mutation in nonsyndromic X-linked mental retardation. Nat Genet 20, 25-30 (1998).

70. Boettner, B. \& Van Aelst, L. The role of Rho GTPases in disease development. Gene 286, 155-74 (2002).

71. Gu, Y. et al. Biochemical and biological characterization of a human Rac2 GTPase mutant associated with phagocytic immunodeficiency. J Biol Chem 276, 15929-38 (2001). 
72. Sehr, P. et al. Glucosylation and ADP ribosylation of rho proteins: effects on nucleotide binding, GTPase activity, and effector coupling. Biochemistry 37, 5296-304 (1998).

73. Liu, S.Y., Yen, C.Y., Yang, S.C., Chiang, W.F. \& Chang, K.W. Overexpression of Rac-1 small GTPase binding protein in oral squamous cell carcinoma. J Oral Maxillofac Surg 62, 702-7 (2004).

74. Kissil, J.L. et al. Requirement for Rac1 in a K-ras induced lung cancer in the mouse. Cancer Res 67, 8089-94 (2007).

75. Malliri, A. et al. Mice deficient in the Rac activator Tiam1 are resistant to Ras-induced skin tumours. Nature 417, 867-71 (2002).

76. Vega, F.M. \& Ridley, A.J. Rho GTPases in cancer cell biology. FEBS Lett 582, 2093-101 (2008).

77. Engers, R., Springer, E., Michiels, F., Collard, J.G. \& Gabbert, H.E. Rac affects invasion of human renal cell carcinomas by up-regulating tissue inhibitor of metalloproteinases (TIMP)-1 and TIMP-2 expression. J Biol Chem 276, 41889-97 (2001).

78. Lozano, E., Betson, M. \& Braga, V.M. Tumor progression: Small GTPases and loss of cellcell adhesion. Bioessays 25, 452-63 (2003).

79. Hall, C. et al. Alpha 2-chimerin, an SH2-containing GTPase-activating protein for the rasrelated protein p21rac derived by alternate splicing of the human $\mathrm{n}$-chimerin gene, is selectively expressed in brain regions and testes. Mol Cell Biol 13, 4986-98 (1993).

80. Leung, T., How, B.E., Manser, E. \& Lim, L. Cerebellar beta 2-chimaerin, a GTPase-activating protein for p21 ras-related rac is specifically expressed in granule cells and has a unique $\mathrm{N}$-terminal SH2 domain. J Biol Chem 269, 12888-92 (1994).

81. Lim, L. n-Chimaerin and neuronal signal transduction mechanisms. Biochem Soc Trans 20, 611-4 (1992).

82. Hall, C. et al. Novel human brain cDNA encoding a 34,000 Mr protein n-chimaerin, related to both the regulatory domain of protein kinase $C$ and $B C R$, the product of the breakpoint cluster region gene. J Mol Biol 211, 11-6 (1990).

83. Ahmed, $\mathrm{S}$. et al. Human brain n-chimaerin CDNA encodes a novel phorbol ester receptor. Biochem J 272, 767-73 (1990).

84. Lim, H.H., Michael, G.J., Smith, P., Lim, L. \& Hall, C. Developmental regulation and neuronal expression of the mRNA of rat n-chimaerin, a p21rac GAP:cDNA sequence. Biochem J 287 ( Pt 2), 415-22 (1992).

85. Hall, C. et al. alpha2-chimaerin, a Cdc42/Rac1 regulator, is selectively expressed in the rat embryonic nervous system and is involved in neuritogenesis in N1E-115 neuroblastoma cells. J Neurosci 21, 5191-202 (2001).

86. Leung, T., How, B.E., Manser, E. \& Lim, L. Germ cell beta-chimaerin, a new GTPaseactivating protein for p21rac, is specifically expressed during the acrosomal assembly stage in rat testis. J Biol Chem 268, 3813-6 (1993).

87. Siliceo, $M$. et al. Beta2-chimaerin provides a diacylglycerol-dependent mechanism for regulation of adhesion and chemotaxis of T cells. J Cell Sci 119, 141-52 (2006).

88. Dong, J.M. \& Lim, L. Selective up-regulation of alpha 1-chimaerin mRNA in SK-N-SH neuroblastoma cells by K+/-induced depolarisation. Eur J Biochem 236, 820-6 (1996).

89. Buttery, P. et al. The diacylglycerol-binding protein alpha1-chimaerin regulates dendritic morphology. Proc Natl Acad Sci U S A 103, 1924-9 (2006).

90. Yuan, S., Miller, D.W., Barnett, G.H., Hahn, J.F. \& Williams, B.R. Identification and characterization of human beta 2-chimaerin: association with malignant transformation in astrocytoma. Cancer Res 55, 3456-61 (1995).

91. Yang, C., Liu, Y., Leskow, F.C., Weaver, V.M. \& Kazanietz, M.G. Rac-GAP-dependent inhibition of breast cancer cell proliferation by \{beta\}2-chimerin. J Biol Chem 280, 2436370 (2005).

92. Dong, J.M., Smith, P., Hall, C. \& Lim, L. Promoter region of the transcriptional unit for human alpha 1-chimaerin, a neuron-specific GTPase-activating protein for p21rac. Eur $J$ Biochem 227, 636-46 (1995). 
93. Dong, J.M. \& Lim, L. The human neuronal alpha 1-chimaerin gene contains a positiondependent negative regulatory element in the first exon. Neurochem Res 21, 1023-30 (1996).

94. Phillips, J.M. \& Goodman, J.I. Multiple genes exhibit phenobarbital-induced constitutive active/androstane receptor-mediated DNA methylation changes during liver tumorigenesis and in liver tumors. Toxicol Sci 108, 273-89 (2009).

95. Donovan, S., Shannon, K.M. \& Bollag, G. GTPase activating proteins: critical regulators of intracellular signaling. Biochim Biophys Acta 1602, 23-45 (2002).

96. Kai, M., Yasuda, S., Imai, S., Kanoh, H. \& Sakane, F. Tyrosine phosphorylation of beta2chimaerin by Src-family kinase negatively regulates its Rac-specific GAP activity. Biochim Biophys Acta 1773, 1407-15 (2007).

97. Hurley, J.H., Newton, A.C., Parker, P.J., Blumberg, P.M. \& Nishizuka, Y. Taxonomy and function of C1 protein kinase C homology domains. Protein Sci 6, 477-80 (1997).

98. Kazanietz, M.G. Novel "nonkinase" phorbol ester receptors: the C1 domain connection. Mol Pharmacol 61, 759-67 (2002).

99. Ahmed, S. et al. The cysteine-rich domain of human proteins, neuronal chimaerin, protein kinase $C$ and diacylglycerol kinase binds zinc. Evidence for the involvement of a zincdependent structure in phorbol ester binding. Biochem J 280 ( Pt 1), 233-41 (1991).

100. Areces, L.B., Kazanietz, M.G. \& Blumberg, P.M. Close similarity of baculovirus-expressed n-chimaerin and protein kinase C alpha as phorbol ester receptors. J Biol Chem 269, 19553-8 (1994).

101. Brose, N., Betz, A. \& Wegmeyer, H. Divergent and convergent signaling by the diacylglycerol second messenger pathway in mammals. Curr Opin Neurobiol 14, 328-40 (2004).

102. Caloca, M.J. et al. Beta2-chimaerin is a high affinity receptor for the phorbol ester tumor promoters. J Biol Chem 272, 26488-96 (1997).

103. Caloca, M.J. et al. beta2-chimaerin is a novel target for diacylglycerol: binding properties and changes in subcellular localization mediated by ligand binding to its $\mathrm{C} 1$ domain. Proc Natl Acad Sci U S A 96, 11854-9 (1999).

104. Caloca, M.J., Wang, H., Delemos, A., Wang, S. \& Kazanietz, M.G. Phorbol esters and related analogs regulate the subcellular localization of beta 2-chimaerin, a non-protein kinase C phorbol ester receptor. J Biol Chem 276, 18303-12 (2001).

105. Wang, H. \& Kazanietz, M.G. Chimaerins, novel non-protein kinase C phorbol ester receptors, associate with Tmp21-I (p23): evidence for a novel anchoring mechanism involving the chimaerin C1 domain. J Biol Chem 277, 4541-50 (2002).

106. Brown, M. et al. Alpha2-chimaerin, cyclin-dependent Kinase 5/p35, and its target collapsin response mediator protein-2 are essential components in semaphorin 3A-induced growth-cone collapse. J Neurosci 24, 8994-9004 (2004).

107. Caloca, M.J., Wang, H. \& Kazanietz, M.G. Characterization of the Rac-GAP (Rac-GTPaseactivating protein) activity of beta2-chimaerin, a 'non-protein kinase $C^{\prime}$ phorbol ester receptor. Biochem J 375, 313-21 (2003).

108. Ahmed, S. et al. Breakpoint cluster region gene product-related domain of n-chimaerin. Discrimination between Rac-binding and GTPase-activating residues by mutational analysis. J Biol Chem 269, 17642-8 (1994).

109. Canagarajah, B. et al. Structural mechanism for lipid activation of the Rac-specific GAP, beta2-chimaerin. Cell 119, 407-18 (2004).

110. Ahmed, S. et al. A novel functional target for tumor-promoting phorbol esters and lysophosphatidic acid. The p21rac-GTPase activating protein n-chimaerin. J Biol Chem 268, 10709-12 (1993).

111. Wang, H. et al. Phospholipase Cgamma/diacylglycerol-dependent activation of beta2chimaerin restricts EGF-induced Rac signaling. Embo J 25, 2062-74 (2006).

112. Colon-Gonzalez, F. \& Kazanietz, M.G. C1 domains exposed: from diacylglycerol binding to protein-protein interactions. Biochim Biophys Acta 1761, 827-37 (2006). 
113. Colon-Gonzalez, F., Leskow, F.C. \& Kazanietz, M.G. Identification of an autoinhibitory mechanism that restricts C1 domain-mediated activation of the Rac-GAP alpha2chimaerin. J Biol Chem 283, 35247-57 (2008).

114. Beg, A.A., Sommer, J.E., Martin, J.H. \& Scheiffele, P. alpha2-Chimaerin is an essential EphA4 effector in the assembly of neuronal locomotor circuits. Neuron 55, 768-78 (2007).

115. Wegmeyer, H. et al. EphA4-dependent axon guidance is mediated by the RacGAP alpha2chimaerin. Neuron 55, 756-67 (2007).

116. Shi, L. et al. Alpha2-chimaerin interacts with EphA4 and regulates EphA4-dependent growth cone collapse. Proc Natl Acad Sci U S A 104, 16347-52 (2007).

117. Takeuchi, S., Yamaki, N., Iwasato, T., Negishi, M. \& Katoh, H. Beta2-chimaerin binds to EphA receptors and regulates cell migration. FEBS Lett 583, 1237-42 (2009).

118. Nagasawa, T., Kikutani, H. \& Kishimoto, T. Molecular cloning and structure of a pre-B-cell growth-stimulating factor. Proc Natl Acad Sci U S A 91, 2305-9 (1994).

119. Caloca, M.J., Delgado, P., Alarcon, B. \& Bustelo, X.R. Role of chimaerins, a group of Racspecific GTPase activating proteins, in T-cell receptor signaling. Cell Signal 20, 758-70 (2008).

120. Qi, R.Z., Ching, Y.P., Kung, H.F. \& Wang, J.H. Alpha-chimaerin exists in a functional complex with the Cdk5 kinase in brain. FEBS Lett 561, 177-80 (2004).

121. Van de Ven, T.J., VanDongen, H.M. \& VanDongen, A.M. The nonkinase phorbol ester receptor alpha 1-chimerin binds the NMDA receptor NR2A subunit and regulates dendritic spine density. J Neurosci 25, 9488-96 (2005).

122. Kozma, R., Ahmed, S., Best, A. \& Lim, L. The GTPase-activating protein n-chimaerin cooperates with Rac1 and $\mathrm{Cdc} 42 \mathrm{Hs}$ to induce the formation of lamellipodia and filopodia. Mol Cell Biol 16, 5069-80 (1996).

123. Dalva, M.B. There's more than one way to skin a chimaerin. Neuron 55, 681-4 (2007).

124. Cheng, Q. et al. Cdk5/p35 and Rho-kinase mediate ephrin-A5-induced signaling in retinal ganglion cells. Mol Cell Neurosci 24, 632-45 (2003).

125. Egea, J. et al. Regulation of EphA 4 kinase activity is required for a subset of axon guidance decisions suggesting a key role for receptor clustering in Eph function. Neuron 47, 515-28 (2005).

126. Leskow, F.C., Holloway, B.A., Wang, H., Mullins, M.C. \& Kazanietz, M.G. The zebrafish homologue of mammalian chimerin Rac-GAPs is implicated in epiboly progression during development. Proc Natl Acad Sci U S A 103, 5373-8 (2006).

127. Engle, E.C. Oculomotility disorders arising from disruptions in brainstem motor neuron development. Arch Neurol 64, 633-7 (2007).

128. Jen, J. et al. Familial horizontal gaze palsy with progressive scoliosis maps to chromosome 11q23-25. Neurology 59, 432-5 (2002).

129. Miyake, N. et al. Human CHN1 mutations hyperactivate alpha2-chimaerin and cause Duane's retraction syndrome. Science 321, 839-43 (2008).

130. Hashimoto, R. et al. A missense polymorphism (H204R) of a Rho GTPase-activating protein, the chimerin 2 gene, is associated with schizophrenia in men. Schizophr Res 73, 383-5 (2005).

131. Mooyaart, A.L. et al. Genetic associations in diabetic nephropathy: a meta-analysis. Diabetologia.

132. Maeda, M. et al. Regulation of vascular smooth muscle proliferation and migration by beta2-chimaerin, a non-protein kinase $\mathrm{C}$ phorbol ester receptor. Int J Mol Med 17, 559-66 (2006).

133. Ridley, A.J. Rho proteins and cancer. Breast Cancer Res Treat 84, 13-9 (2004).

134. Fritz, G. \& Kaina, B. Rho GTPases: promising cellular targets for novel anticancer drugs. Curr Cancer Drug Targets 6, 1-14 (2006).

135. Yang, C., Liu, Y., Lemmon, M.A. \& Kazanietz, M.G. Essential role for Rac in heregulin beta1 mitogenic signaling: a mechanism that involves epidermal growth factor receptor and is independent of ErbB4. Mol Cell Biol 26, 831-42 (2006). 
136. Menna, P.L. et al. Inhibition of aggressiveness of metastatic mouse mammary carcinoma cells by the beta2-chimaerin GAP domain. Cancer Res 63, 2284-91 (2003).

137. Yang, C., Klein, E.A., Assoian, R.K. \& Kazanietz, M.G. Heregulin beta1 promotes breast cancer cell proliferation through Rac/ERK-dependent induction of cyclin D1 and p21Cip1. Biochem J 410, 167-75 (2008).

138. Bruinsma, S.P., Cagan, R.L. \& Baranski, T.J. Chimaerin and Rac regulate cell number, adherens junctions, and ERK MAP kinase signaling in the Drosophila eye. Proc Natl Acad Sci U S A 104, 7098-103 (2007).

139. Stephens, K. et al. Preferential mutation of the neurofibromatosis type 1 gene in paternally derived chromosomes. Hum Genet 88, 279-82 (1992).

140. Yuan, B.Z. et al. DLC-1 operates as a tumor suppressor gene in human non-small cell lung carcinomas. Oncogene 23, 1405-11 (2004).

141. Borkhardt, A. et al. The human GRAF gene is fused to MLL in a unique $t(5 ; 11)(q 31 ; q 23)$ and both alleles are disrupted in three cases of myelodysplastic syndrome/acute myeloid leukemia with a deletion 5q. Proc Natl Acad Sci U S A 97, 9168-73 (2000).

142. Tikoo, A. et al. p190-A, a human tumor suppressor gene, maps to the chromosomal region 19q13.3 that is reportedly deleted in some gliomas. Gene 257, 23-31 (2000).

143. Knudson, A.G., Jr. Mutation and cancer: statistical study of retinoblastoma. Proc Natl Acad Sci U S A 68, 820-3 (1971).

144. Debnath, J., Muthuswamy, S.K. \& Brugge, J.S. Morphogenesis and oncogenesis of MCF$10 \mathrm{~A}$ mammary epithelial acini grown in three-dimensional basement membrane cultures. Methods 30, 256-68 (2003).

145. Bacus, S.S., Kiguchi, K., Chin, D., King, C.R. \& Huberman, E. Differentiation of cultured human breast cancer cells (AU-565 and MCF-7) associated with loss of cell surface HER2/neu antigen. Mol Carcinog 3, 350-62 (1990).

146. Lasfargues, E.Y., Coutinho, W.G. \& Redfield, E.S. Isolation of two human tumor epithelial cell lines from solid breast carcinomas. J Natl Cancer Inst 61, 967-78 (1978).

147. Katayose, Y. et al. Promoting apoptosis: a novel activity associated with the cyclindependent kinase inhibitor p27. Cancer Res 57, 5441-5 (1997).

148. Hackett, A.J. et al. Two syngeneic cell lines from human breast tissue: the aneuploid mammary epithelial (Hs578T) and the diploid myoepithelial (Hs578Bst) cell lines. J Natl Cancer Inst 58, 1795-806 (1977).

149. Bronzert, D.A., Greene, G.L. \& Lippman, M.E. Selection and characterization of a breast cancer cell line resistant to the antiestrogen LY 117018. Endocrinology 117, 1409-17 (1985).

150. Gaffney, E.V., Pigott, D.A. \& Grimaldi, M.A. Human serum and the growth of human mammary cells. J Natl Cancer Inst 63, 913-8 (1979).

151. Sugarman, B.J. et al. Recombinant human tumor necrosis factor-alpha: effects on proliferation of normal and transformed cells in vitro. Science 230, 943-5 (1985).

152. Brinkley, B.R. et al. Variations in cell form and cytoskeleton in human breast carcinoma cells in vitro. Cancer Res 40, 3118-29 (1980).

153. Gazdar, A.F. et al. Characterization of paired tumor and non-tumor cell lines established from patients with breast cancer. Int J Cancer 78, 766-74 (1998).

154. Tomlinson, G.E. et al. Characterization of a breast cancer cell line derived from a germ-line BRCA1 mutation carrier. Cancer Res 58, 3237-42 (1998).

155. Ross, R.A., Spengler, B.A. \& Biedler, J.L. Coordinate morphological and biochemical interconversion of human neuroblastoma cells. J Natl Cancer Inst 71, $741-7$ (1983).

156. Rosenzweig, T. et al. Related to testes-specific, vespid, and pathogenesis protein-1 (RTVP1 ) is overexpressed in gliomas and regulates the growth, survival, and invasion of glioma cells. Cancer Res 66, 4139-48 (2006).

157. Giard, D.J. et al. In vitro cultivation of human tumors: establishment of cell lines derived from a series of solid tumors. J Natl Cancer Inst 51, 1417-23 (1973). 
158. Galli, R. et al. Isolation and characterization of tumorigenic, stem-like neural precursors from human glioblastoma. Cancer Res 64, 7011-21 (2004).

159. Diserens, A.C. et al. Characterization of an established human malignant glioma cell line: LN-18. Acta Neuropathol 53, 21-8 (1981).

160. Chomczynski, P. \& Sacchi, N. Single-step method of RNA isolation by acid guanidinium thiocyanate-phenol-chloroform extraction. Anal Biochem 162, 156-9 (1987).

161. Orita, M., Iwahana, H., Kanazawa, H., Hayashi, K. \& Sekiya, T. Detection of polymorphisms of human DNA by gel electrophoresis as single-strand conformation polymorphisms. Proc Natl Acad Sci U S A 86, 2766-70 (1989).

162. Xiao, W. \& Oefner, P.J. Denaturing high-performance liquid chromatography: A review. Hum Mutat 17, 439-74 (2001).

163. Davuluri, R.V., Grosse, I. \& Zhang, M.Q. Computational identification of promoters and first exons in the human genome. Nat Genet 29, 412-7 (2001).

164. Takai, D. \& Jones, P.A. Comprehensive analysis of CpG islands in human chromosomes 21 and 22. Proc Natl Acad Sci U S A 99, 3740-5 (2002).

165. Gilchrist, D.M., Friedman, J.M., Rogers, P.C. \& Creighton, S.P. Myelodysplasia and leukemia syndrome with monosomy 7: a genetic perspective. Am J Med Genet 35, 437-41 (1990).

166. Uhl, G.R. et al. Molecular genetics of successful smoking cessation: convergent genomewide association study results. Arch Gen Psychiatry 65, 683-93 (2008).

167. Schlaepfer, I.R., Hoft, N.R. \& Ehringer, M.A. The genetic components of alcohol and nicotine co-addiction: from genes to behavior. Curr Drug Abuse Rev 1, 124-34 (2008).

168. Liao, Y.C., Shih, Y.P. \& Lo, S.H. Mutations in the focal adhesion targeting region of deleted in liver cancer-1 attenuate their expression and function. Cancer Res 68, 7718-22 (2008).

169. Desmet, F.O. et al. Human Splicing Finder: an online bioinformatics tool to predict splicing signals. Nucleic Acids Res 37, e67 (2009).

170. Ferrer-Costa, C. et al. PMUT: a web-based tool for the annotation of pathological mutations on proteins. Bioinformatics 21, 3176-8 (2005).

171. Scholz, R.P. et al. DLC1 interacts with 14-3-3 proteins to inhibit RhoGAP activity and block nucleocytoplasmic shuttling. J Cell Sci 122, 92-102 (2009).

172. Kawashima, T. et al. A Rac GTPase-activating protein, MgcRacGAP, is a nuclear localizing signal-containing nuclear chaperone in the activation of STAT transcription factors. Mol Cell Biol 29, 1796-813 (2009).

173. Sandrock, K., Bielek, H., Schradi, K., Schmidt, G. \& Klugbauer, N. The nuclear import of the small GTPase Rac1 is mediated by the direct interaction with karyopherin alpha2. Traffic 11, 198-209.

174. Jones, B. \& Chen, J. Inhibition of IFN-gamma transcription by site-specific methylation during T helper cell development. Embo J 25, 2443-52 (2006).

175. Govek, E.E., Newey, S.E. \& Van Aelst, L. The role of the Rho GTPases in neuronal development. Genes Dev 19, 1-49 (2005).

176. Lerman, C. \& Berrettini, W. Elucidating the role of genetic factors in smoking behavior and nicotine dependence. Am J Med Genet B Neuropsychiatr Genet 118B, 48-54 (2003).

177. Goode, E.L. et al. Multiple genome-wide analyses of smoking behavior in the Framingham Heart Study. BMC Genet 4 Suppl 1, S102 (2003).

178. Mayfield, R.D., Harris, R.A. \& Schuckit, M.A. Genetic factors influencing alcohol dependence. Br J Pharmacol 154, 275-87 (2008).

179. Zhang, S., Day, I.N. \& Ye, S. Microarray analysis of nicotine-induced changes in gene expression in endothelial cells. Physiol Genomics 5, 187-92 (2001). 
